SHINJI HIRAI

\title{
Nostalgias en un mundo transnacional \\ Hacia la reconstrucción del terruño, culturas e identidades entre California y Jalostotitlán, Jalisco
}

TESIS DE DOCTORADO EN CIENCIAS ANTROPOLOGICAS

Universidad Autónoma Metropolitana

Unidad Iztapalapa, División de Ciencias Sociales y Humanidades

Departamento de Antropología

MÉXICO, 2007 
Índice

Agradecimientos

Introducción

Capítulo 1

El estudio de las imágenes en el contexto de la teoría transnacional: Hacia una etnografía del terruño imaginado

Capítulo 2

Jalostotitlán ante la nostalgia y la alienación

Capítulo 3

Campo y Ciudad: El surgimiento de las vacaciones de los migrantes y la nueva imagen del espacio rural

Capítulo 4

Viajes sagrados: Migración y Prácticas religiosas transnacionales

Capítulo 5

Producción, venta y consumo de signos de terruño

Capítulo 6

Nostalgia en polémica: ¿Oposición entre los norteños y la población no migrante?

Capítulo 7

Con los brazos abiertos: Armonización de sentimientos y terruños imaginarios

Conclusiones

Bibliografía 


\section{Agradecimientos}

Para realizar este trabajo he recibido la colaboración de muchas personas, quienes con sus ideas, tiempo y apoyo emocional enriquecieron las diferentes fases de la investigación.

En primer lugar, deseo agradecer a Federico Besserer por el apoyo intelectual que me ha brindado desde el inicio de mis estudios de posgrado. Esta tesis no hubiera llegado a su fin sin su asesoría.

Quisiera agradecer también a Raúl Nieto y Michael Kearney por todo el apoyo que me brindaron durante la redacción de esta tesis. A Mario Humberto, Daniel Hiernaux, Margarita Zarate, Fernando Herrera, Ludger Pries, Rafael Alarcón, Daniel Ramírez y Marcial Godoy por sus comentarios y sugerencias que me dieron en el desarrollo de esta investigación.

Este trabajo también debe mucho a la solidaridad y el apoyo de mis compañeros del grupo multidisciplinario sobre procesos transnacionales de la Universidad Autónoma Metropolitana, Unidad Iztapalapa (UAM-I). Gracias a las discusiones que tuvimos en los seminarios y a la revisión detallada de cada capítulo de esta tesis, pude concluir esta obra.

Quiero agradecer a Julieta Salgado por la corrección minuciosa del último borrador de esta tesis. A Oscar Ortiz mi agradecimiento por su amistad y por escuchar siempre con paciencia mis ideas acerca de la nostalgia y enseñarme la riqueza del vocabulario español.

Mis estudios de posgrado en el Departamento de Antropología de la UAM-I no hubieran llegado a su fin sin el apoyo institucional que recibí durante mi estancia en México. Todavía recuerdo con agrado el día en que visité por primera vez el Departamento de Antropología con mucho nervio en el año 1999. Desde entonces, los profesores y el personal de esta institución me han tratado con paciencia y tolerancia para que yo pudiera sentir un ambiente hogareño en la universidad.

La realización de la investigación etnográfica en la que se basa esta tesis, fue posible gracias a los siguientes financiamiento: una beca otorgada durante 
primeros dos años de mis estudios de posgrado por el Gobierno de México, a través del Instituto Mexicano de Cooperación Internacional (IMEXCI) de la Secretaría de Relaciones Exteriores; otra beca otorgada en el año 2004 por la Fundación Rockefeller y el proyecto de investigación "Transnacionalismo, ciudadanía y exclusión social" de la UAM-I.

Tengo más grandes deudas con los jalostotitlenses en México y Estados Unidos. Les agradezco de corazón por haberme permitido asomarme a una parte de sus vidas y por haberme proporcionado información invaluable sobre sus pensamientos y sentimientos. El apoyo y la amistad que me brindaron durante el trabajo de campo no sólo enriquecieron esta investigación, sino también mi vida entre México y Japón. Doy gracias a todos los jalostotitlenses que me enseñaron la importancia del apego a la familia y a la tierra natal. Sus narrativas nostálgicas me convencieron para viajar regularmente a mi país natal después de tantos años sin haber regresado. Particularmente, quiero expresar mi agradecimiento a don Antonio González Márquez y su familia, don Francisco Javier Reynoso Gutiérrez, don Jesús Jáuregui, el Sr. Miguel González Reynoso, don Antonio Lozano, Juan Manuel Reynoso, Antonio García y los integrantes de la Asociación de Nuestra Señora de la Asunción en Turlock, quienes me ayudaron a realizar el trabajo de campo en California. Al Sr. Severiano Jáuregui Pérez, mi gratitud por haberme obsequiado dos ejemplares de su libro sobre las narrativas vívidas de los migrantes. Al Sr. José Juan Gutiérrez Reynoso, cronista Luis Jesús Ramírez Jiménez y mi amigo Víctor Manuel Jiménez, mi agradecimiento por su colaboración en Jalostotitlán. Quisiera agradecer también a Javier Franco López y su familia por su amistad y por haberme ofrecido generosamente alojamiento en su casa durante la investigación en Jalostotitlán. Asimismo, doy gracias a todos mis amigos de Jalos por su amistad y el apoyo que me brindaron durante el trabajo de campo. ¡Nos vemos pronto en el carnaval de Jalos!

Finalmente, debo agradecer a mi familia por su constante apoyo que me ha enviado desde Japón a lo largo de los años. Desde el día en que les hablé a mis padres mi sueño de estudiar en México hace diez años, ellos me han brindado el 
apoyo incondicional con comprensión y amor a pesar de que mi sueño significaba su enorme sacrificio emocional.

Y claro, este trabajo y mi vida en México serían imposibles sin mi esposa Violeta, a quien tuve fortuna de conocer por haber emigrado a este país. 


\title{
Introducción
}

\author{
Pueblo, mi pueblo querido, \\ en ti yo busco el consuelo \\ del caminante perdido; \\ me siento como un polluelo \\ que se recoge a su nido. \\ Las campanas de mi pueblo \\ que alegres cantando están, \\ parece que van diciendo: \\ Jalos....Jalostotitlán! \\ Pedro Rodríguez Lomelí, "Las campanas de mi pueblo", \\ En un Pueblo Alteño.
}

Nostalgia rises to importance as a cultural practice as culture becomes more and more diffuse, [...] as culture takes on the power of "distance" that comes of displacing speakers

Kathleen Stewart (1988: 227)

"Homeland" [...] remains one of the most powerful unifying symbols for mobile and displaced people

Akhil Gupta y James Ferguson (1997: 39)

El 31 de octubre de 2004, yo estaba en el coche que manejaba don Antonio, un migrante jubilado de origen mexicano que ha vivido en el condado de Orange, California, durante casi cincuenta años. Ese domingo, él y doña Teresa, su esposa, me invitaron a ir a una misa que se iba a dar en español en una iglesia católica en Anaheim y otra en La Habra. En el camino a las iglesias y en el regreso a su casa, en el interior del coche se escuchaban las melodías y sonidos grabados en un casete insertado en el estéreo: el sonido de las campanas de la iglesia, la melodía de la serenata interpretada por una orquesta, la música de una banda de instrumentos de viento, las canciones en español, el himno de la Virgen de la Asunción, etc.

La mayoría de las canciones y sonidos grabados en ese casete era lo que había grabado el mismo don Antonio con una mini-grabadora en Jalostotitlán, su tierra natal que se encuentra en los Altos de Jalisco en el occidente de México y se ubica alrededor de mil quinientas millas de distancia de donde él y su esposa 
viven en Estados Unidos. Por ejemplo, la melodía de la serenata interpretada por una orquesta fue grabada por él a las dos de la mañana en Jalostotitlán cuando él hizo un viaje de retorno temporal para las fiestas de su tierra natal. Esa cinta también contenía algunas canciones y programas de radio relacionados con Jalostotitlán que fueron grabados por él en California o por sus familiares que vivían en México. Esa cinta de sonidos y melodías de su terruño, igual que otras que se guardaban en su coche, era la que don Antonio había editado reuniendo varias grabaciones que coleccionaba para regalar a sus amigos originarios de Jalostotitlán que radicaban en Estados Unidos como él o para su uso personal.

De las bocinas del estéreo, se comenzó a escuchar la transmisión en directo por una estación de radiodifusión de Los Ángeles. Era la transmisión del Baile de Coronación de la Reina organizado por el Club Social Jalostotitlán de Los Ángeles en 1971. De repente, comenzó la música interpretada por una orquesta en el mismo evento. Don Antonio me explicó que la orquesta se llamaba la "Orquesta De la Cruz", el grupo musical más popular de Jalostotitlán en su juventud y el nombre de la canción era "Súplica del amor". Escuchando la melodía que llenaba el interior del coche, doña Teresa me dijo que era una canción favorita de su padre y que cuando ella la escuchaba, le recordaba a su padre, a sus paisanos que lloraban en el Baile de Coronación de la Reina cuando la orquesta comenzó a interpretar esa canción, y a la época en que don Antonio y ella eran novios cuando vivían en Jalostotitlán. Entonces, ellos comenzaron a hablar de cómo era el noviazgo en su terruño en el pasado y narraron otros recuerdos de su lugar de origen. Las melodías y sonidos de Jalostotitlán, que habían cruzado la frontera y habían sido reunidos de distintos lugares y períodos en una cinta, ahora creaban una conexión simbólica y emocional con su terruño ubicado a mil quinientas millas de distancia del condado de Orange. Con las melodías se evocaban las imágenes y los recuerdos sobre su tierra natal y la nostalgia hacia su terruño.

La nostalgia es un término que fue inventado por un médico suizo en la segunda mitad del siglo XVII por la combinación de dos palabras griegas, nostos (significa regresar a casa) y algos (significa sufrimiento). Durante casi 300 años en Europa, la nostalgia había sido considerada como una enfermedad o un desorden 
psíquico. ${ }^{1}$ Pero hoy en día entendemos que la nostalgia es un estado de ánimo relacionado con el desplazamiento. Es la tristeza, el malestar o el dolor causado por la distancia y la separación de la tierra natal y de los seres queridos al viajar a un lugar lejano. Al parecer, es normal que aquellos migrantes, como don Antonio y su esposa, que viven una separación espacial del terruño, experimenten y manifiesten este sentimiento, dado que la migración es un desplazamiento que crea una distancia física entre el lugar de origen y el lugar de destino. Sin embargo, al revisar la historia de la migración de Jalostotitlán hacia Estados Unidos y las conexiones transnacionales que se han desarrollado en torno a esta migración, se cuestiona la "distancia" que existe entre la localidad emisora de los migrantes y el país receptor, y la nostalgia aparece como un sentimiento problemático.

\section{MIGRACIÓN DE JALOSTOTITLÁN HACIA ESTADOS UNIDOS}

Jalostotitlán es la localidad cabecera del municipio del mismo nombre que se encuentra en los Altos de Jalisco en el Estado de Jalisco. Es una ciudad habitada por 21,656 personas. $^{2}$ En esta localidad, la historia de la migración hacia Estados Unidos comenzó a principios del siglo $X X{ }^{3}$ De la primera década del siglo a la segunda mitad de los años veinte, muchos de los jalostotitlenses que se fueron a Estados Unidos trabajaban en la construcción, la reparación y el mantenimiento de las vías férreas en California y otros estados del suroeste del país. ${ }^{4}$

${ }^{1}$ Véanse la nota que hizo Edward Brown sobre las concepciones históricas de nostalgia y el trabajo de Sedikides et al. (2004).

2 INEGI (2006), II Conteo de Población y Viviendas, 2005, Resultados Definitivos. Tabulados Básicos, México.

${ }^{3}$ En la primera década del siglo XX, la salida masiva de la gente del occidente de México para buscar trabajos en Estados Unidos ya se había convertido en un fenómeno social tan notorio que en las prensas regionales y estatales y en los informes municipales y estatales, se empezaba a hablar de las quejas y preocupaciones sobre algunos problemas sociales causados por la migración en el Estado de Jalisco, Michoacán y Guanajuato. Jalostotitlán fue uno de estos municipios donde hubo quejas sobre la falta de mano de obra en 1906, debido a la migración internacional (Durand, 1994: 113). En este período, los estados que enviaba más migrantes mexicanos hacia Estados Unidos eran Guanajuato, Michoacán, Jalisco y Zacatecas (114).

4 Según las historias orales capturadas durante el trabajo de campo realizado en Jalostotitlán y en California, en la década de 1910 también había jalostotitlenses que se iban a Estados Unidos. Estos primeros flujos poblacionales de Jalostotitán hacia el Norte no sólo surgieron por el aumento de la demanda de mano de obra en estos sectores laborales del suroeste de Estados Unidos, sino también por las situaciones políticas del lado sur de la 
Entrando en la segunda mitad de los años veinte, se dio un evento importante que provocó el desplazamiento de un gran número de jalostotitlenses: la guerra cristera. Fue un movimiento armado con carácter religioso que estalló en 1926 como respuesta por parte de los católicos a la Ley de Cultos que decretó el presidente Elías Calles para sujetar la autoridad de la iglesia a la del estado. En este acontecimiento histórico, Jalostotitlán y otros lugares de la región alteña se convirtieron en una de las principales escenas de las batallas entre los cristeros y el ejército federal. El 31 de julio de 1926, justo un día antes de comenzar las fiestas patronales de Jalostotitlán, se cerraron el templo y las iglesias de la localidad. En abril del siguiente año, el párroco del Templo de Nuestra Señora de la Asunción salió del país para exiliarse voluntariamente en Estados Unidos. ${ }^{5} \mathrm{El}$ templo y las iglesias de Jalostotitlán se convirtieron en cuarteles del ejército federal. Durante tres años de la guerra cristera, los habitantes vivieron bajo el terror y la preocupación. ${ }^{6}$ La inseguridad política y social de la localidad durante este acontecimiento obligó a un gran número de familias irse a las ciudades cercanas del occidente de México y Estados Unidos. ${ }^{7}$

Al terminar los conflictos en 1929, aquellos que se refugiaron en Estados Unidos comenzaron a retornar. ${ }^{8}$ Sin embargo, los campos agrícolas que habían

frontera en este período. Por ejemplo, cuando estalló la Revolución Mexicana en 1910, la emigración del occidente de México hacia Estados Unidos aumentó notablemente (Massey et al., 1991: 54). Aunque hubo poca participación de los habitantes del occidente de México en el proceso militar y político, esta región fue el escenario de algunas batallas y el lugar de paso de trenes y de tropas revolucionarias. En este contexto, la crisis económica, la ausencia de trabajo, la inseguridad y el hambre afectaron seriamente a los pobladores del occidente de México y algunos optaron por irse a Estados Unidos (Durand, 1994:116). Como otros lugares del occidente de México, Jalostotitlán participó en este acontecimiento histórico como lugar de paso de las tropas revolucionarias (Gutiérrez Gutiérrez, 1985: 233, 234).

${ }^{5}$ Gutiérrez Gutiérrez (1985: 252).

${ }_{7}^{6}$ Padilla (1988: 166).

${ }^{7}$ José Antonio Gutiérrez Gutiérrez, historiador originario de Jalostotitlán, considera que la guerra cristera fue el evento histórico que comenzó "una emigración masiva, fenómeno que se convierte en contínuo hasta nuestro días" (1985: 272) aunque esta vez el éxodo masivo aún no tenía el carácter laboral tan marcado.

${ }^{8}$ Padilla (1988: 1974, 180). Aunque José Trinidad Padilla L., cronista de Jalostotitlán, y las memorias de algunas familias que se fueron a Estados Unidos durante la guerra cristera explican que el motivo del retorno a Jalostotitlán fue el fin de los conflictos en su terruño, cabe recordar que había otra situación en Estados Unidos que les obligaba a los migrantes regresar a su país. Me refiero a la deportación masiva de los migrantes mexicanos durante la década de los años treinta. 
sido abandonados durante la guerra cristera, no estaban en la condición de sostener la base de la economía local. ${ }^{9}$ Entrando a la década de los cuarenta, la localidad de Jalostotitlán que siempre buscaba una solución en la emigración al enfrentarse con alguna situación difícil, comenzó a enviar a una gran cantidad de jalostotitlenses al Norte cuando inició el Programa Bracero. Durante el período de este programa, los jalostotitlenses que cruzaron la frontera iniciaron sus vidas laborales en Estados Unidos trabajaron principalmente en el sector agrícola. Al terminar la temporada de cosechas, algunos regresaron a su terruño, otros permanecieron en el país del norte para buscar trabajo en las zonas urbanas. ${ }^{10}$

${ }^{9}$ Desde finales de los años veinte y la década de los años treinta, se había creado un contexto en que Jalostotitlán estaba listo para comenzar una migración masiva laboral desde los años cuarenta. En este período, hubo un cambio social significativo que se dio en el campo. Según el análisis de José Antonio Gutiérrez Gutiérrez (1985), a partir de esta etapa, "la hacienda dejó de ser el modelo de organización territorial, para ser sustituida por la pequeña propiedad como forma predominante" $(265,266)$. La inestabilidad económica y política que dejó el movimiento cristero en Jalostotitlán provocó el empobrecimiento de la localidad, debido a la salida de los hacendados hacia Guadalajara, la Ciudad de México, Aguascalientes o León con sus capitales. La reducción en la producción agropecuaria y subsistencia básica por el descuido del campo durante el movimiento cristero, la depresión económica mundial y la amenaza de la reforma agraria fueron factores que presionaron y estimularon a los hacendados a vender sus propiedades o fraccionarlas excesivamente (265).

La consecuencia del fraccionamiento excesivo de las tierras y de la venta de las propiedades era el surgimiento de un gran número de propietarios de los pequeños ranchos familiares que combinaban la agricultura maicera con la ganadería que producía carne y leche para el consumo familiar y local. Sin embargo, se presentó una situación crítica para estos rancheros en este período en Jalostotitlán, igual que toda la región de los Altos de Jalisco. Hubo un crecimiento demográfico en los ranchos porque "los jóvenes se casaban a la temprana edad de los 18 años y las muchachas entre los 15 y 17, de tal manera que el número promedio de familia era entre 8 y 10 hijos" (261). Aunque se fraccionara la propiedad, la agricultura de Jalostotitlán no podía producir mucho, apenas producían para subsistir por las tierras "flacas" (272), dado que, como otros lugares de los Altos de Jalisco, el clima de la región con el discontinuo ritmo de las lluvias y de la sequedad y el tipo de suelo de origen volcánico de los Altos de Jalisco son poco propicios para la agricultura (Fábregas, 1986: 27).

Ante esta situación, los pequeños propietarios estaban obligados a buscar una forma de hacer rendir mejor sus propiedades, introduciendo nuevas técnicas y tecnología para la agricultura y la ganadería. No obstante, sin dinero ni crédito, no podían hacer mucho con estas tierras (Gutiérrez Gutiérrez, 1985: 266).

En esta situación desproporcionada entre la tasa de crecimiento demográfico y los recursos productivos tanto del medio ambiente como tecnológico, la migración hacia Estados Unidos surgió como una válvula de escape (Fábregas, 1986: 30; González de la Rocha y Escobar Latapí, 1990: 520).

${ }^{10}$ La participación de Estados Unidos en la Segunda Guerra Mundial creó una alta demanda de la mano de obra, sobre todo en la agricultura. En 1942 comenzó el Programa Bracero para mandar de manera legal a los trabajadores mexicanos principalmente al mercado laboral estadounidense. Durante casi dos décadas que duró el Programa Bracero, el Estado de Jalisco fue uno de los estados del centro y occidente de México que enviaron más 
Después de que se abolió este programa en 1964, la migración hacia el Norte que se había generalizado entre los habitantes de Jalostotitlán no se frenó, debido a las redes de relaciones familiares y sociales con los jalostotitlenses que se quedaron en el país del norte y a los conocimientos y la información acumulados durante el período del Programa Bracero entre los habitantes de Jalostotitlán sobre el cruce fronterizo y sobre la vida migratoria en Estados Unidos. Desde los años sesenta, muchos de los habitantes se fueron a Estados Unidos, principalmente a California de manera indocumentada. También había migrantes que cruzaron la frontera con visas para turistas $u$ otros tipos de documentos. ${ }^{11}$ Asimismo en este período, el número de los jalostotitlenses en California comenzó a aumentar rápidamente de distintos modos: la reunificación familiar; el nacimiento de hijos; la introducción de más paisanos de Jalostotitlán en las fábricas, hoteles, restaurantes y sitios de construcción, en donde había algunas personas originarias de Jalostotitlán trabajando como encargados del grupo de trabajo. ${ }^{12}$

A diferencia del patrón migratorio en las décadas anteriores, desde los años sesenta, los migrantes tendían a trabajar en los sectores no agrícolas, tales como, el sector industrial, textil, de construcción y de servicios, y a vivir en las zonas urbanas de California. Aunque la migración de Jalostotitlán hacia Estados Unidos se constituía de hombres, una vez que ellos consiguieron trabajos estables y/o legalizaron sus estatus migratorios, llamaron a sus esposas e hijos a sus lugares

braceros a Estados Unidos (Durand, 1994: 132). El patrón migratorio de esta época tenía tres características: la migración dominantemente masculina, temporal y dirigida hacia las actividades agrícolas (Durand, 1994: 133).

Cabe señalar que durante el período del Programa Bracero, la migración indocumentada se desarrolló de manera paralela. Según Durand, esta migración no necesariamente coincidía con las características del flujo de los migrantes contratados. Los indocumentados podían ser hombres o mujeres. Además, la migración no era necesariamente temporal ni se dirigía exclusivamente al sector agrícola. Los migrantes sin contratos se movían con libertad dentro de Estados Unidos y podían prolongar su estancia y conseguir trabajos en las actividades no agrícolas (Durand, 1994: 133, 134).

${ }^{11}$ Muchos de mis entrevistados habían cruzado la frontera de los años sesenta a la primera mitad de los años ochenta en distintos modos: algunos cruzaron la línea brincando las rejas o caminando por la playa, otros entraron a Estados Unidos como turistas, como periodistas o como familiar del ciudadano estadounidense.

${ }^{12}$ Entre los migrantes originarias de Jalostotitlán se dice mayordomo para referirse al encargado del grupo de trabajo (en inglés, foreman). Cuando necesitaban los mayordomos más personas en sus trabajos, iban a buscar a algunos sitios de California donde se reunían los jóvenes recién llegados de su lugar de origen. 
de destino y comenzaron a establecerse con sus familias en ese país. Alrededor de los años ochenta, esta tendencia al establecimiento en Estados Unidos se volvía notoria porque los jalostotitlenses compraron sus propias casas en los lugares de destino y algunos iniciaron sus propios negocios, tales como, la tienda de abarrotes, la compañía de construcción, la agencia de bienes raíces, la fábrica, el taller mecánico, el hotel y el restaurante. ${ }^{13}$

Después de la segunda mitad de los años ochenta, la tendencia a las actividades laborales y el asentamiento en las zonas urbanas se ha vuelto aún más notoria. Además, gracias a la legislación de Immigration Reform and Control Act (IRCA), conocida como la ley Simpson-Rodino en 1986, y a las redes de relaciones sociales con los jalostotitlenses ya establecidos en Estados Unidos, la migración hacia el Norte ha aumentado drásticamente. ${ }^{14}$ En cuanto a la distribución geográfica de los jalostotitlenses en Estados Unidos, California es el estado en donde se concentran los migrantes originarios de Jalostotitlán. ${ }^{15}$ En las zonas urbanas de los condados de Los Ángeles y Orange, hay varias localidades en donde se han asentado un gran número de familias jalostotitlenses, como South Gate y Anaheim. En el norte de California, también hay lugares con gran asentamiento de los jalostotitlenses, como Sacramento y Turlock. Sin embargo, en los años recientes, la población jalostotitlense también se ha expandido hacia otros estados, tales como Indiana, Illinois, Texas, Arizona, Nuevo México y Colorado.

${ }^{13}$ En el libro escrito por un migrante jalostotitlense, hay varias entrevistas con sus paisanos que tenían negocios propios en Estados Unidos (Jáuregui Pérez, 1981).

${ }^{14}$ Véase González de la Rocha y Escobar Latapí (1990). Ellos analizan el impacto de esta reforma migratoria en patrones migratorios a partir de los resultados de investigaciones cuantitativas realizadas en el municipio de Jalostotitlán. Alguna de las tendencias de la migración jalostotitlense hacia Estados Unidos después de la legislación de la IRCA es la salida masiva de los habitantes del municipio de Jalostotitlán de manera legal o de manera indocumentada (1991: 524, 536, 544).

Otro resultado de su investigación es que el $69 \%$ de los hogares entrevistados en 1986 en la cabecera municipal tenía personas con experiencia migratoria internacional (1991: 522).

${ }^{15}$ Esta estimación de la distribución geográfica de los jalostotitlenses en Estados Unidos, se basa en el directorio de domicilios de los ausentes que hizo la parroquia de Jalostotitlán y las observaciones de los migrantes y los habitantes de Jalostotitlán con quienes me entrevisté durante las investigaciones etnográficas realizadas en esta localidad y California. El término ausente se refiere a aquellas personas originarias de Jalostotitlán radicadas fuera de esta localidad. 


\section{LAS CONEXIONES TRANSNACIONALES ENTRE JALOSTOTITLÁN Y CALIFORNIA}

Sin embargo, esta migración hacia Estados Unidos no ha sido un desplazamiento que convierta a Jalostotitlán en un terruño remoto con el cual es difícil de mantener el vínculo para los migrantes y que rompa con sus relaciones sociales y prácticas culturales arraigadas en el lugar de origen. Al contrario, a lo largo de la historia de la migración de Jalostotitlán hacia Estados Unidos, para los migrantes radicados en California, el "terruño" ha sido un símbolo que se hace cada vez más presente en sus vidas. Aunque viven en distintas localidades, ciudades y condados del Estado de California, los migrantes han mantenido las relaciones sociales con sus familiares y sus paisanos que viven en otros lugares de California.

Las redes de relaciones sociales entre los migrantes también se han mantenido y fortalecido por medio de las organizaciones de los migrantes y sus actividades colectivas. En la segunda mitad de los años sesenta, los jalostotitlenses radicados en el sur de California fundaron el Club Social Jalostotilán de Los Ángeles. Este club organizaba cada año el Baile de Coronación de la Reina y las fiestas patronales de su terruño durante casi una década. En el mismo período, los jalostotitlenses radicados en el norte de California organizaron otro Club Social Jalostotitlán en Sacramento. Estos clubes de los migrantes actualmente dejaron de existir. Pero las fiestas de la Virgen de la Asunción, patrona de la parroquia de Jalostotitlán, se organizan cada agosto en Turlock, condado de Stanislaus, y en el sur de California, de una manera simultánea con las fiestas patronales celebradas en Jalostotitlán. A finales de los años ochenta, se estableció la Fundación Jalostotitlán en el condado de Orange para recaudar donaciones entre los jalostotitlenses radicados en Estados Unidos con el fin de enviar apoyos económicos y materiales al sector menos beneficiado de la población en Jalostotitlán.

Asimismo, los migrantes han mantenido las prácticas culturales arraigadas en su lugar de origen a pesar de vivir lejos de su terruño. En sus hogares, pueden comer diario platillos mexicanos porque pueden conseguir con facilidad los 
alimentos mexicanos en los supermercados cercanos que administran sus paisanos de Jalostotitlán u otros migrantes de origen mexicano en el sur de California. Igual que cuando vivían en su terruño, pueden participar cada domingo en una misa en español en las iglesias cercanas a sus casas. La devoción por la Virgen de la Asunción también se ha mantenido a través de las imágenes sagradas que ellos mismos llevaron de Jalostotitlán para sus casas y para la celebración de las fiestas patronales.

Además, a pesar de que la mayoría de los migrantes se han establecido con sus familias en Estados Unidos, han construido los vínculos con su terruño en distintos modos: el viaje de retorno temporal en temporada de fiestas locales en Jalostotitlán les permite a los migrantes tener el contacto directo con su terruño; las remesas personales para los miembros de sus familias que se quedan en el terruño y las remesas colectivas de las organizaciones de los migrantes han mantenido el vínculo económico con Jalostotitlán; los apoyos que brindan los migrantes que ya se encuentran en Estados Unidos a sus familiares y amigos del terruño para encontrar alojamiento y trabajo, han facilitado la llegada de nuevos migrantes al Norte; las visitas del presidente municipal y los sacerdotes de la parroquia de Jalostotitlán a los lugares de destino de los migrantes han servido para mantener el contacto con las autoridades locales del terruño, y una serie de objetos que viajan a Estados Unidos con los migrantes después de terminar las fiestas locales, como productos típicos del lugar de origen, carteles, fotos y películas de las festividades locales, han servido para que los migrantes puedan tener el contacto simbólico con su terruño mientras viven en el país del norte.

Cabe mencionar que estas nuevas prácticas sociales, económicas, religiosas y culturales que se han inventado en las últimas cuatro décadas de la historia de la migración de Jalostotitlán hacia Estados Unidos para mantener y fortalecer las relaciones sociales entre los migrantes y los vínculos con su terruño, también han extendido el espacio social donde habitan los jalostotitlenses más allá de los territorios geográficos de su localidad de origen o de sus lugares de destino, y al mismo tiempo, han contribuido ampliar la topografía de las identidades arraigadas en Jalostotitlán. Por ejemplo, en un sitio de Internet titulado con el nombre de su 
terruño, numerosos jóvenes migrantes originarios de Jalostotitlán y de segunda generación les escriben a sus paisanos mensajes desde distintos puntos de Estados Unidos. Al entrar a la página de comentarios, muchos de esos visitantes que se encuentran fuera de Jalostotitlán escriben “iHola! Soy de Jalos”. En esa página, un joven de Anaheim dejó el siguiente comentario ingenioso que demuestra que algunos lugares de destino en el sur de California han sido apropiados como parte de Jalostotitlán: "Para mí, Anaheim es el segundo Jalos, y Escondido, CA., es el tercer Jalos".

En suma, esta migración no se puede entender con el modelo de "asimilación" a la cultura dominante del país receptor, dado que a pesar de haber cruzado la frontera y vivir la distancia física con su terruño, los migrantes jalostotitlenses han mantenido las prácticas culturales arraigadas en su lugar de origen. Esta migración tampoco ha sido un desplazamiento que obliga a los migrantes a vivir en dos mundos separados. Más bien, los migrantes originarios de Jalostotitlán viven en un "mundo transnacional" que se constituye de las conexiones sociales, económicos, políticos y simbólicos entre Jalostotitlán y Estados Unidos a través de los flujos transnacionales intensificados de personas, objetos, dinero y símbolos, las organizaciones e instituciones que eslabonan a los migrantes con su terruño y las relaciones sociales y las prácticas culturales arraigadas en Jalostotitlán.

Desde los años noventa, en las ciencias sociales ha surgido una nueva corriente de los estudios de migraciones internacionales que explora los procesos que se dan en el país receptor de los migrantes junto con otros que se observan en el país de origen, a través del enfoque en las conexiones transnacionales. En este nuevo campo de estudio que se denomina los estudios de migraciones transnacionales, se han propuesto varios modelos de espacio transnacional para entender los procesos sociales que se dan a través de las prácticas sociales, económicas, políticas y culturales de los migrantes, las cuales eslabonan la sociedad emisora con la receptora. Aunque los investigadores denominan sus modelos de espacio de distintos modos, tales como, espacios sociales transnacionales (Faist, 1999), circuitos migratorios transnacionales (Rouse, 1989; 
1991), campos sociales transnacionales (Glick Schiller et al., 1992), comunidades transnacionales (Kearney y Nagengast, 1989), se puede observar las siguientes características comunes: 1) la circulación constante de personas, dinero, ideas y símbolos entre el país receptor y el país de origen de los migrantes; 2) la extensión de las relaciones sociales de la sociedad de origen más allá de las fronteras nacionales; 3 ) la continuidad de las prácticas sociales y culturales de la sociedad de origen en el país receptor; 4) la existencia de las instituciones y organizaciones políticas, sociales y religiosas que vinculan el país de origen con el país receptor, y 5) la reducción de la distancia social entre el país receptor y el país de origen a pesar de que los migrantes viven la distancia física con su país de origen.

El mundo transnacional que se ha construido entre Jalostotitlán y California a raíz del fenómeno migratorio es un espacio social que coincide justamente con estas características. En este mundo transnacional, a pesar de que existe una enorme distancia espacial entre los lugares de destino y el lugar de origen, los migrantes viven dentro de las conexiones transnacionales que reducen la distancia social con su terruño y convierten a su lugar de origen en una localidad que está presente en sus vidas en el país receptor.

\section{3. ¿POR QUÉ HAY NOSTALGIA EN UN MUNDO TRANSNACIONAL?}

Sin embargo, al tomar en cuenta el hecho de que también existen en este mundo, donde el terruño de los migrantes se ve relativamente "cerca" de los lugares de destino, las narrativas nostálgicas de los migrantes radicados en Estados Unidos, como la de don Antonio y su esposa, surge una pregunta: ¿Por qué hay nostalgia a pesar de vivir un mundo transnacional? Al parecer, es normal que los individuos manifiesten este sentimiento al separarse de su tierra natal, dado que por lo general entendemos que la nostalgia es un estado de ánimo relacionado con el desplazamiento espacial y basado en una separación del lugar y de los seres queridos que dejan los viajeros. Pero aquí la nostalgia aparece como una subjetividad problemática, e incluso contradictoria al tomar en cuenta el hecho de que la construcción y el fortalecimiento de las conexiones 
transnacionales entre Jalostotitlán y California es un proceso que desafia la "distancia" entre la sociedad emisora y la receptora de los migrantes. Si los migrantes viven en un mundo transnacional donde pueden vivir relativamente "cerca" de su terruño y gozar de la similitud social y cultural al terruño en sus lugares de destino, no deberían de sentir la nostalgia. Pero la realidad etnográfica explica que sí hay nostalgia dentro de un mundo social construido a través de múltiples conexiones transnacionales entre Jalostotitlán y California. ¿Por qué hay nostalgia en un mundo transnacional donde el terruño de los migrantes se acerca cada vez más a sus vidas en el país receptor?

Algunos antropólogos señalan que en el mundo contemporáneo, donde la circulación transnacional de personas, objetos, dinero, símbolos e información erosiona los límites de localidades, regiones y naciones, se pierde la validez de la idea de que en un espacio dividido y separado de otros, hay una cultura y una identidad arraigada en él y confinada dentro de él (Appadurai, 1996; Clifford, 1999; Gupta y Ferguson, 1997; Hannertz, 1998). En este momento transnacional, la imagen de la cultura confinada dentro del marco local, regional o nacional se debilita y se fragmenta por los flujos que mueven a las personas y los elementos culturales de un lugar o un país hacia otros. Sin embargo, en la situación en que las culturas, que se suponían que estaban localizadas en ciertos espacios divididos, pierden sus ancladeros, también es cierto que muchos grupos étnicos y sociales móviles y desplazados se imaginan y recuerdan sus terruños como lugares culturalmente distintos de otros (Gupta y Ferguson, op.cit.: 39). Uno de los sentimientos especiales que ellos retienen en sus terruños es la nostalgia. Para las personas móviles y desplazadas, la nostalgia aparece como un sentimiento importante para reconstruir las memorias y la imaginación personal o colectiva sobre sus terruños y sobre la imagen de la cultura localizada y para constituir algunos aspectos de sus vidas, conciencias y la realidad social. En este sentido, la nostalgia es uno de los objetos de estudio importantes para entender las formas en que las personas móviles unifican los símbolos y reconstruyen y representan sus culturas, identidades y nuevas realidades sociales en el contexto transnacional. 
¿Por qué muchos migrantes sienten apego a su terruño? ¿Por qué el terruño sigue siendo un lugar especial para aquellos migrantes que cruzan las fronteras pero construyen y mantienen los vínculos sociales, económicos, políticos, simbólicos y emocionales con su lugar de origen? ¿Qué tipo de imagen de terruño evocan a los migrantes los símbolos que viajan entre su lugar de origen y los lugares de destino? ¿Qué significado tienen la imaginación y los sentimientos hacia su terruño para sus vidas en la sociedad receptora? ¿Cómo influyen sus terruños imaginarios en la realidad social de su terruño y en la vida de aquellas personas que se quedan ahí? Aunque estas son algunas de las preguntas de las cuales nos permiten partir para el entendimiento de los procesos de transformación de culturas, identidades y la realidad social en el contexto de la migración transnacional, la dimensión emocional de la vida de los migrantes ha sido un tema poco explorado hasta ahora en los estudios de migraciones transnacionales.

A pesar de ello, algunos investigadores que han trabajado el caso de migraciones de México hacia Estados Unidos señalan que los sentimientos nostálgicos que manifiestan los migrantes juegan un papel sumamente importante en la construcción y en el desarrollo de las relaciones sociales y prácticas que eslabonan la sociedad receptora con la emisora. Por ejemplo, Massey y sus coautores sostienen que los migrantes mexicanos "retienen un fuerte apego sentimental a su terruño, lo cual se expresa en una ideología muy pronunciada que favorece y legitima la migración de retorno" (1991: 15). Asimismo, Espinosa argumenta que el dilema entre el establecimiento en el país receptor y el deseo de retorno sustentado por una fuerte nostalgia "ha jugado un papel primordial en el reforzamiento de los lazos que unen en un solo espacio transnacional los lugares de origen y destino de los migrantes" (1998: 44). Sin embargo, a pesar del señalamiento de la importancia de la dimensión emocional de los procesos migratorios, la nostalgia de los migrantes hacia sus terruños no ha sido el objeto central de estudio en la literatura sobre migraciones, y por lo tanto, no se han explicado de qué manera se construyen los sentimientos que aferran a los migrantes a sus lugares de origen, cómo se experimentan y expresan en formas 
individuales y colectivas y cómo influye realmente la nostalgia en la construcción de las conexiones transnacionales y en la transformación de culturas, identidades y la realidad social.

Lo que pretendo en esta tesis es, a través del enfocarme en la nostalgia que experimentan y expresan los migrantes en forma individual y colectiva hacia su terruño, explorar los procesos de reconstrucción del terruño, culturas e identidades en distintas dimensiones de un mundo transnacional que se constituyen por las conexiones entre el lugar de origen y el país receptor de los migrantes originarios de Jalostotitlán. En este sentido, esta tesis es una etnografía sobre diversas formas de nostalgia que surgen en los procesos transnacionales que se han dado entre Jalostotitlán y California en torno al fenómeno migratorio hacia Estados Unidos.

\section{DISEÑO DE INVESTIGACIÓN}

Mi primera visita a Jalostotitlán fue a mediados de agosto de 2000 , justo unos días antes de la culminación de las fiestas patronales. Como yo aún estaba en la etapa de la elaboración de un proyecto de investigación para mis estudios de posgrado, el objetivo de ese viaje era buscar un tema de investigación etnográfica. Terminando la maestría, volví a Jalostotitlán en febrero de 2003 para iniciar el trabajo de campo. Desde entonces, realicé el trabajo de campo cada año en febrero y agosto, los meses en los que regresan un gran número de jalostotitlenses radicados en Estados Unidos para asistir a las festividades locales. También realicé repetidas visitas a Jalostotitlán y a otras localidades cercanas fuera de la temporada de fiestas locales. En octubre de 2004, hice una estancia de casi un mes en California, sobre todo, en las zonas urbanas donde se concentran los migrantes jalostotitlenses originarios de Jalostotitlán en los condados de Los Ángeles y Orange. Pero, para tener entrevistas con las personas que me podían dar alguna información importante acerca de las actividades colectivas de los migrantes en California, también viajé a La Quinta, condado de Riverside, y a Turlock, condado de Stanislaus. 
Por lo general, estos trabajos de campo consistían en los siguientes métodos: la observación participante en los eventos de las fiestas locales en Jalostotitlán, en el consumo cultural tanto en esa localidad como en los supermercados y restaurantes en el sur de California y en las prácticas religiosas de los migrantes en California; las entrevistas con los migrantes y los habitantes, los organizadores de las fiestas y las autoridades civiles y religiosas de Jalostotitlán, y la recolección de las imágenes de terruño que se representan en objetos, narrativas de los migrantes, textos, páginas de Internet y discursos de algunos actores sociales y políticos que rodean a la vida de los migrantes. Cada uno de estos trabajos de campo en distintos lugares de México y Estados Unidos a veces duraba un mes, otras veces sólo un par de días.

En suma, esta tesis no se basa en una investigación etnográfica ortodoxa que se caracteriza por el trabajo de campo durante un largo plazo en un solo lugar. Más bien, lo que pretendí hacer a través de una serie de trabajos de campo durante un plazo corto en distintos lugares fue una "investigación etnográfica multilocal" que propone George E. Marcus (1998). Marcus sostiene que para describir etnográficamente las fuerzas políticas y económicas que rodean a los sujetos de estudio más allá del contexto local, es fundamental que el investigador mismo se mueva de un sitio a otro, siguiendo literalmente un objeto de estudio seleccionado conforme a su tema de investigación. En mi caso, para explorar la extensión espacial y los procesos de construcción de las conexiones transnacionales entre Jalostotitlán y California y para entender cómo los sentimientos, memorias e imaginación construidos en un sitio viajan y operan sobre la realidad de otro lugar, yo mismo viajé entre distintos lugares de México y California, siguiendo las imágenes del terruño que se construyen, representan y consumen por los sujetos que están situados en distintos lugares y en diferentes posicionamientos. En este sentido, esta tesis no es una etnografía sobre una localidad o sobre el terruño y los lugares de destino de los migrantes. Más bien, es una etnografía sobre las conexiones transnacionales construidas entre estos lugares por los sentimientos y por los flujos de personas y símbolos. 
Era cierto que para realizar este tipo investigación etnográfica de manera individual en un terreno de investigación con una extensión geográficamente enorme, tuve que enfrentarme con ciertas dificultades y limitaciones: por ejemplo, el número de personas entrevistadas; el costo y el tiempo que se requieren para el trabajo de campo realizado en cada lugar, y una enorme magnitud de la población estudiada (tan sólo el número de habitantes de la localidad de Jalostotitlán es más de 20,000. Si se agrega a esta cifra el número de los migrantes originarios de Jalostotitlán, la totalidad del grupo estudiado es de un número mucho mayor.). Lo que intenté hacer bajo estas limitaciones y dificultades no fue abordar toda la realidad de un mundo transnacional que se ha construido entre Jalostotitlán y California, sino recolectar los fragmentos de la realidad social para reconstruir etnográficamente ciertas dimensiones de este mundo tan amplio.

Por su parte, me dediqué a ordenar, analizar, seleccionar y editar los datos etnográficos para reconstruir la realidad social del mundo transnacional de los jalostotitlenses al regresar a la Ciudad de México después de haber terminado cada uno de trabajos de campo y toda la investigación en los campos en el año 2005. En cierta forma, este ejercicio antropológico de unir los datos para escribir una etnografía en el "hogar", es decir, el sitio de residencia y pertenencia del investigador separado del campo, era semejante a una práctica de muchos migrantes jalostotitlenses radicados en California. Durante el trabajo de campo en California, me había dado cuenta de que ellos guardaban algunos objetos que representaban las imágenes de su terruño: carteles de las fiestas de Jalostotitlán pegados en la pared del estudio de sus casas; fotos del paisaje y de sus familiares en Jalostotitlán; libros sobre la historia local de su terruño; la imagen de la Virgen de la Asunción encuadrada en la sala o en la recámara, etc. Al narrar sus historias de vida y recuerdos del terruño, en muchas ocasiones, ellos me enseñaban algunos de estos objetos para complementar sus narrativas. De una manera semejante, yo también había coleccionado en el estudio de mi casa varios objetos de lugares distantes, como folletos de fiestas locales de Jalostotitlán y de eventos celebrados en California por los migrantes, textos sobre la historia de Jalostotitlán, fotos del lugar de origen y los lugares de destino de los migrantes, grabaciones 
digitales de las entrevistas realizadas en California, cintas de video de las fiestas religiosas en Jalostotitlán y diarios de campo. Usaba estos fragmentos de la realidad recolectados en distintos lugares distantes de la Ciudad de México para reconstruir algunas dimensiones del mundo transnacional de los jalostotitlenses en la etnografía. En este sentido, la reconstrucción de la realidad social de un mundo distante en la vida cotidiana de los viajeros a partir de los fragmentos del lugar lejano no sólo es una práctica privilegiada de los migrantes, sino también del etnógrafo.

También hay otra razón por la cual el modo en que escribo la etnografía tiene cierta semejanza y "resonancia" con la forma en que los migrantes reconstruyen y narran la realidad social del terruño. Durante esta investigación etnográfica multilocal, la Ciudad de México, en donde radico y estudio en la universidad, no necesariamente ha sido para mí un "hogar", es decir, un sitio de residencia y pertenencia en donde el etnógrafo analiza los datos y escribe la etnografía a partir de la separación del campo. ${ }^{16}$ En 1998, salí de Japón, mi país natal, para comenzar mis estudios de posgrado en México. Durante estos nueve años de mi estancia en el país, formé una familia aquí y he vivido en este país manteniendo una relación estrecha con la comunidad japonesa en la Ciudad de México y el vínculo con mi país de origen. Por eso, el "hogar" como punto de partida del viaje de investigación y punto de regreso para escribir la etnografía ha sido un sitio que me sitúa en la extranjería y en otra transnacionalidad.

Para mí, alguien que siempre tiene que narrar sobre la familia, las costumbres, las relaciones sociales y la identidad a partir de las conexiones transnacionales, el "hogar" no necesariamente es un sitio de oposición, contraste y separación del campo, sino un sitio de acercamiento a la visión del mundo de los sujetos de estudio a través de mis propias experiencias y un sitio de reflexión comparativa entre una transnacionalidad y otra. Por eso, las miradas etnográficas desde las cuales se analizan, interpretan y describen los casos estudiados, no sólo consisten

16 Véanse el capítulo 1 y el 3 del libro de Clifford (1999). Él sostiene que, además de repensar, a partir de la noción de "viaje", la idea de los "nativos" como sujetos inmovilizados y localizados en el campo y la idea del campo como un sitio sólo para la "residencia", es importante considerar que el hogar que contrasta con el campo también se puede entender a partir del viaje. 
en una óptica antropológica, sino también en una mirada de "resonancia" con los sujetos de estudio y otra de comparación entre una transnacionalidad y otra.

Cabe mencionar que durante la investigación, el hecho de ser un investigador japonés que vive como migrante en el país de origen de los migrantes jalostotitlenses, me facilitó las entrevistas con los migrantes y la observación participante en sus actividades, aunque al principio mi presencia en los sitios donde casi no se ven japoneses causaba la curiosidad e inquietud entre ellos. En California, al realizar el trabajo de campo en las zonas concentradas por la población de origen mexicano, siempre sentía miradas de curiosidad e inquietud de la gente. Cuando estaba haciendo observación participante en las misas en español en las iglesias, en los supermercados de alimentos mexicanos y en el restaurante-bar mexicano en el sur de California, yo era el único asiático en esos sitios y el objeto de miradas curiosas pero discretas de los demás. Sin embargo, después de explicarles a algunos de ellos en español que yo también venía de México o de Jalos (apócope de Jalostotitlán), me permitieron hacerles entrevistas con agrado. Por ejemplo, en el otoño del año 2004, fui a Xalos bar, uno de los puntos de reunión importantes para los jóvenes originarios de Jalostotitlán en el sur de California, con el fin de hacer una entrevista con alguna persona originaria de Jalos que trabajaba ahí. Cuando conocí a uno de los dueños de ese negocio, me preguntó, sin ocultar sospechas en su rostro, en qué medio de comunicación yo iba a publicar el reportaje y para qué iba a usar los datos. Sin embargo, después de explicarle que estaba haciendo una investigación sobre los migrantes jalostotitlenses e iba a usar los datos básicamente para mi tesis doctoral y otros trabajos académicos y que había viajado a Jalos en repetidas ocasiones desde el año 2000, desapareció la tensión que había mostrado en su rostro y me comentó que él también había estado en las fiestas de agosto de Jalos en ese año. Después de una breve charla acerca de Jalos y sus fiestas, me invitó a almorzar juntos y posteriormente me dio facilidades para conocer a sus clientes y empleados originarios de Jalos y entrevistarme con algunos ellos en el interior de la instalación de su negocio. 
En el trabajo de campo en Jalostotitlán, muchos migrantes que regresaban para las fiestas de su terruño, al principio, me hablaban en inglés pensando que yo era un asiático que también venía de California o de alguna otra parte de Estados Unidos. Sin embargo, al enterarse de que yo hablaba mejor español que inglés y que yo era un japonés que vivía en México, algunos me decían que yo era un migrante como ellos aunque con la diferencia de que yo había viajado de un país desarrollado a su país de origen y ellos habían emigrado de México a otro país desarrollado. Esta postura de "resonancia" entre las experiencias de los migrantes de vivir en la extranjería en Estados Unidos y las mías en México me permitió participar en varias actividades de los migrantes durante las fiestas locales. Por ejemplo, el 16 de agosto, se celebra el día de los ausentes como parte de las ceremonias de las fiestas patronales. Ausentes es un término que se usa en Jalostotitlán para referirse a aquellos jalostotitlenses que no viven en su terruño. El 16 de agosto de 2004, cuando yo estaba observando el inicio de la peregrinación de los ausentes, un migrante radicado en California que ya me conocía me regaló una calcomanía para los ausentes y me invitó a formar parte de la peregrinación, porque para él yo era una persona que también vivía en un país extranjero y visitaba cada año Jalostotitlán como ellos.

Estos encuentros conmigo, con un investigador que no es mexicano ni estadounidense, en las zonas urbanas con alta densidad de población de origen mexicano o en una provincia mexicana, no sólo les provocaron a los jalostotitlenses sorpresas, curiosidades, e incluso, sospechas durante el trabajo de campo, sino también me obligaban a explicarles las circunstancias en las que yo había llegado a Jalos o a los barrios mexicanos del sur de California y el tema y los objetivos de mi investigación para aclarar la incertidumbre que aparentemente habían tenido acerca de mi presencia. Sin embargo, esa condición de encuentro nos permitió enfocar en el tema de investigación en el momento de entrevista con muchos de mis informantes y me facilitaron recolectar los datos etnográficos satisfactorios durante una plaza relativamente corto de trabajo de campo para explorar cada uno de los temas de investigación. José Juan Gutiérrez Reynoso, quien estaba en el cargo de director de Casa de la Cultura de Jalostotitlán durante 
el período de mis repetidas visitas a esa localidad, fue uno de los entrevistados, y al mismo tiempo, "entrevistadores" sobre mis intereses académicos en Jalostotitlán. Él fue una de las personas que habían prestado el interés en qué opinaba de Jalos y cómo lo veía alguien externo de su tierra natal y del proceso migratorio de México hacia Estados Unidos. En agosto de 2004, me invitó a aportar un artículo sobre mi idea de los procesos transnacionales del caso jalostotitlense a Sin fronteras, una revista local sobre la migración mexicana hacia Estados Unidos que publicaba una organización civil en la que participaba él. Su intención de publicar mi artículo en un medio que difundía la información sobre el fenómeno migratorio tanto entre los habitantes de Jalostotitlán como entre los migrantes radicados en Estados Unidos, fue que los jalostotitlenses conocieran la opinión externa sobre su tierra natal y que muchos de ellos conocieran mis intereses académicos con el fin de facilitarme el acercamiento con ellos tanto en Jalos como en Estados Unidos. ${ }^{17}$

Por último, debo confesar que al realizar esta investigación etnográfica sobre la nostalgia, mis experiencias de vivir en el extranjero, de sentir de vez en cuando la añoranza por Japón, de consumir los objetos que evocan las imágenes de mi país de origen y de hacer el viaje de retorno temporal, han influido en la selección del tema de investigación y en la elaboración de la perspectiva teórica de este estudio. Particularmente, mi interés en el impacto de la nostalgia en la realidad social del terruño y la metodología para explorarlo fueron inspirados por el texto de antropóloga Jennifer Robertson (1991), Native and Newcomer: Making and remaking a Japanese City, una excelente monografía sobre la nostalgia en el contexto del proyecto nacional de furusato-zukuri (construcción de vieja villa) en Japón. Este trabajo antropológico sobre mi país natal que leí en los primeros años de mi estancia en México me inspiró a hacer una reflexión comparativa entre la ciudad en donde realizó esta antropóloga en Japón y mi pueblo natal cuando yo realizaba viajes de retorno temporal a Japón y me abrió un panorama para ver cómo se transformó mi pueblo natal despoblado en uno de los lugares de

\footnotetext{
${ }^{17}$ HIRAI, Shinji, "La comunidad transnacional jalostotitlense", pp.10-11, Sin fronteras,
} Año 1, No.2, diciembre de 2003. 
atracción en escenario del turismo regional, y posteriormente comencé a identificar una similitud entre la nostalgia del caso japonés y la del caso jalostotitlense en cuanto al uso de los sentimientos para la transformación de la realidad social. En este sentido, no puedo negar que una buena parte de intuición e inspiraciones que produjeron mis intereses académicos y la perspectiva teórica para este estudio etnográfico, fueron un producto de repetidos diálogos que he hecho durante casi una década de mi estancia en México entre lo que había vivido en Japón, lo que he pensado y sentido de mi terruño a distancia y los datos que conseguí en Jalos y en California.

\section{ESTRUCUTURA DE LA TESIS}

En el capítulo 1, presento el marco teórico de la tesis con la que pretendo analizar e interpretar los casos etnográficos en los capítulos posteriores. En la primera parte del capítulo, examino dos campos de estudio de las ciencias sociales que han desarrollado discusiones importantes para estudiar culturas en el mundo contemporáneo caracterizado por la circulación transnacional de personas, objetos, dinero, ideas, información y símbolos: el primer campo de estudio que reviso es una nueva corriente de la antropología que podría denominarse antropología transnacional; el segundo campo de estudio es una nueva corriente de los estudios de migraciones internacionales que propone nuevos modelos de espacio social para analizar los procesos que se dan en el país receptor de los migrantes junto con otros procesos que se observan en el país de origen a través del enfoque en las conexiones transnacionales, la cual denomino los estudios de migraciones transnacionales. Después de explicar las limitaciones de los estudios de migraciones transnacionales y presentar algunos conceptos y aproximaciones que se proponen en otros géneros de estudio sobre el viaje y subjetividades, propongo una metodología de seguir la imagen. Es una metodología que permite analizar la relación entre la construcción y la representación del imaginario sobre el terruño y la transformación del terruño y de las prácticas espaciales y culturales y explorar los aspectos simbólicos, económicos, sociales, políticos y emocionales 
de los procesos transnacionales en los que se involucran más de dos grupos sociales y múltiples localidades.

Comienza la parte etnográfica de la tesis en el capítulo 2, en el cual analizo distintas formas de narrativas nostálgicas de los jalostotitlenses desplazados sobre el terruño. Lo que demuestran distintas formas narrativas sobre la nostalgia presentadas en este capítulo, es que el viaje físico no es la única forma de separarse del terruño, sino que también hay otras formas de experimentar el sentido de distancia. La alienación que experimentan los migrantes en distintas formas en sus vidas migratorias en Estados Unidos es la causa de la formación del sentimiento con el cual ellos se imaginan y representan Jalostotitlán como "tierra prometida" para transformarse en seres sociales diferentes de lo que son ahora. Pero el significado del terruño imaginario que construyen los migrantes varía dependiendo del posicionamiento que ocupa cada individuo.

En el capítulo 3, examino la formación y los efectos socioeconómicos y culturales de la añoranza por el rancho, por el pueblo y por el estilo de vida rural que se manifiesta de manera persistente en las narrativas de los migrantes jalostotitlenses sobre su terruño. Los migrantes jalostotitlenses han perdido doblemente el campo: primero lo perdieron al irse a Estados Unidos, y luego, lo perdieron por la urbanización de su tierra natal. Sin embargo, desde que se ha generalizado el retorno temporal masivo de los migrantes en temporada de fiestas locales, el paisaje del "pueblo rural" se ha materializado en los escenarios festivos de Jalostotitlán. Para entender este nuevo proceso de transformación del terruño, mi enfoque radica en la articulación de los procesos migratorios, el surgimiento de las vacaciones de los migrantes y la formación de la nostalgia hacia el espacio rural con los procesos locales en Jalostotitlán. Aquí, los términos "campo" y "ciudad", como se titula ese capítulo, son claves para entender las migraciones transnacionales, la transformación de Jalostotitlán, así como el cambio en la forma de percepción del terruño.

En el capítulo 4, se discute el tema del apego al terruño que se manifiesta y se refuerza en la dimensión religiosa de la vida de los migrantes. A pesar de haberse establecido en Estados Unidos, los jalostotitlenses radicados en California 
han mantenido relaciones sociales entre los paisanos y el vínculo social, simbólico y emocional con su lugar de origen, a través de la inserción de las prácticas religiosas y las imágenes sagradas del terruño en la sociedad receptora. Asimismo, exploro cómo estas prácticas religiosas populares de los migrantes y sus sentimientos hacia el lugar sagrado y los símbolos religiosos del terruño han sido apropiados por las instituciones religiosas para incorporar a la población migrante tanto en las iglesias locales en el país de origen como en las iglesias en el país receptor.

En el capítulo 5, analizo las actividades comerciales de los jalostotitlenses que se han insertado en el mercado donde se producen, se venden y se consumen los signos de terruño tanto en su terruño como en California, a partir de enfocarme en los puntos de entrecruce entre la dimensión emocional, la simbólica y la económica de la vida de los migrantes y en la relación entre la nostalgia, la identidad y el consumo cultural. En la dimensión económica de la vida de los migrantes, la nostalgia hacia México y el terruño ha sido la base del deseo adquisitivo y el patrón de consumo de los migrantes, y al mismo tiempo, se ha utilizado como eslogan publicitario por el sector comercial tanto en la sociedad receptora como en su lugar de origen.

En el capítulo 6, se presenta la forma conflictiva de la nostalgia. La nostalgia no necesariamente es un sentimiento privilegiado de aquellos jalostotitlenses que se separaron físicamente de su terruño por la migración hacia Estados Unidos, sino que también es un sentimiento que se despierta en aquellos que permanecen en ese lugar o en México. Lo que pretendo explicar en ese capítulo es cómo dos formas de nostalgia hacia el mismo lugar se chocan y provocan una polémica entre los migrantes y la población no migrante de Jalostotitlán. A medida que se ha generalizado el retorno temporal masivo de los migrantes y se materializan en los escenarios festivos de Jalostotitlán las expectativas de los jóvenes sobre las fiestas locales, en la última década algunos sectores de la población local han manifestado el sentido de pérdida del terruño y de los valores tradicionales locales y preocupaciones sobre el impacto del fenómeno migratorio en la vida local. De estas interpretaciones negativas sobre las consecuencias de procesos de 
fortalecimiento del vínculo transnacional con el país del norte, ha surgido un localismo que critica a la migración y a los migrantes por la "destrucción de la cultura local" y propone una identidad local a partir del rechazo de las influencias culturales de Estados Unidos. Sin embargo, esto tuvo respuestas severas por parte de algunos migrantes radicados en California. Mi intención del análisis de este caso etnográfico es descodificar desde distintos ángulos el mecanismo que produce las tensiones sociales entre los jalostotitlenses en vez de analizarlas a partir de una simple oposición entre los migrantes y los no migrantes como tal.

En el capítulo 7, examino dos casos etnográficos de las prácticas culturales de las fiestas locales que buscan construir una noción de ciudadanía e identidad jalostotitlense más incluyente con sentimientos y terruños imaginarios colectivos que abrazan la heterogeneidad de las experiencias de los jalostotitlenses. En ese capítulo, la nostalgia surge no como un sentimiento que se estanca solamente en el pasado, sino como una motivación para cambiar el presente, una esperanza del futuro o un deseo de transformar Jalostotitlán en un lugar en donde tanto los migrantes como los habitantes puedan encontrar el sentido de pertenencia y que puedan llamar su propio terruño.

El último capítulo está dedicado a conclusiones para sintetizar distintas formas de nostalgia que se explican del capítulo 2 al capítulo 7. Lo que se puede observar en los casos etnográficos sobre la nostalgia que aparece en distintas dimensiones de la vida de los migrantes, es que existen las relaciones entre la formación de los sentimientos hacia el terruño y sus efectos socioeconómicos, culturales y políticos. La formación de la nostalgia no se puede separar de las realidades y fuerzas socioeconómicas, culturales y políticas que rodean tanto al lugar de origen de los migrantes como a los lugares de destino. Además, la nostalgia es un sentimiento que influye en la realidad y se utiliza como el recurso económico, el capital social y cultural, el instrumento político y el motor de la construcción y fortalecimiento de las conexiones transnacionales por múltiples actores que intentan acercarse a los migrantes. 


\section{Capítulo 1}

El estudio de las imágenes en el contexto de la teoría transnacional:

Hacia una etnografía del terruño imaginado

\section{INTRODUCCIÓN}

En gran parte de los trabajos sobre culturas en la antropología tradicional, la cultura había sido estudiada a través del trabajo de campo realizado en una sociedad relativamente pequeña durante un tiempo largo para enfocarse en las personas y los procesos observados en el mismo espacio. Algunas de las consecuencias de la investigación etnográfica que se basa en la estrategia de localización intensa de los sujetos de estudio y su cultura en el "campo", son describir a los sujetos de estudio y su cultura como si estos dos existieran ahí en forma relativamente autónoma y hasta cierto punto separado del mundo exterior y marginar en la etnografía la realidad histórica y social constituida por las conexiones con otros lugares, regiones y países. ${ }^{18}$

Sin embargo, en el contexto en que la circulación constante de personas, objetos, dinero, ideas, información y símbolos entre lugares, regiones y países se ha intensificado en muchas partes del mundo contemporáneo, los antropólogos se han enfrentado con la situación que les obliga a repensar su modo convencional de hacer estudios etnográficos sobre culturas alrededor de las siguientes preguntas: ¿Cómo podemos estudiar culturas los antropólogos en el mundo contemporáneo caracterizado por la circulación transnacional de personas, objetos, dinero, ideas, información y símbolos? ¿Qué tipo de estudios culturales podemos plantear para explorar vínculos entre lo local y lo global o lo transnacional y relaciones entre aquellos que permanecen en un lugar y otros que viajan a otros lugares y países? ¿Cómo podemos definir el sujeto de estudio y el espacio de investigación, construir la metodología y realizar el trabajo de campo para hacer estudios culturales que se enfocan en los procesos transnacionales?

${ }^{18}$ En cuanto a la reflexión sobre el modo convencional de trabajo de campo, véase el capítulo 3 del libro de Clifford (1999). 
Hay dos campos de estudio de las ciencias sociales que han desarrollado discusiones importantes para responder a estas cuestiones. El primero es una corriente de la antropología que podría denominarse antropología transnacional. Desde los años noventa, han propuesto conceptos y aproximaciones innovadores para el análisis cultural algunos antropólogos, tales como, Arjun Appadurai (1991, 1996), James Clifford (1999), Goerge Marcus (1998), Ulf Hannerz (1989, 1998), etc. ${ }^{19}$ Otro campo de estudio que ha contribuido de manera importante a las discusiones antropológicas sobre cómo hacer investigaciones etnográficas dentro y sobre el mundo interconectado es una nueva corriente de los estudios de migraciones internacionales que propone nuevos modelos de espacio transnacional para analizar los procesos sociales, políticos, económicos y culturales que se dan en el país receptor de los migrantes internacionales junto con otros procesos que se observan en el país de origen, a través del enfoque en las conexiones transnacionales. Este campo de estudio lo denomino los estudios de migraciones transnacionales.

El objetivo de este capítulo es situar las discusiones de los estudios de migraciones transnacionales en los debates antropológicos de cultura, espacio y sujeto de estudio, aclarar las limitaciones de las principales perspectivas de los estudios de migraciones transnacionales sobre espacios y revisar algunas propuestas de los estudios sobre viajes que cubren estas limitaciones para construir un nuevo marco teórico y una metodología que permitan explorar la formación cultural que se da en el ámbito transnacional a través del enfoque en el proceso de producción y consumo de la imagen que circula más allá de las fronteras nacionales.

El capítulo consiste en cuatro apartados. En el primer apartado, revisaré brevemente los debates que se han dado en la antropología en las últimas dos décadas en torno al concepto de cultura junto con el de espacio y sujeto de

${ }^{19}$ Estos antropólogos denominan nuevos estudios etnográficos que tienen el alcance del análisis a procesos globales y transnacionales en distintos modos: Appadurai (1991) propone la "macroetnografía", Hannarz (1989) usa el término "macroantropología", Clifford (1999) propone el concepto de "culturas viajeras" y Marcos (1998) plantea la "investigación etnográfica multilocal. Denomino esta corriente de nuevas propuestas antropológicas como antropología transnacional. Es el término que Appadurai (1991) usó en el subtítulo de su artículo. 
estudio para contextualizar el interés creciente de esta disciplina en los procesos globales y transnacionales, los cuales son precisamente fenómenos sociales que obligan a la antropología a enfrentarse con los problemas teóricos y conceptuales en la era de globalización.

En el segundo apartado de este capítulo, revisaré los trabajos pioneros de los llamados estudios de migraciones transnacionales. Esta nueva literatura de las ciencias sociales ha sido engrosada por los trabajos de distintas disciplinas en las últimas dos décadas. Esta literatura trata de explicar los vínculos entre lo local y lo global a partir de lo transnacional, particularmente a través del análisis de los procesos migratorios transnacionales, y plantea nuevas aproximaciones para el entendimiento del proceso de construcción del espacio y los nuevos sujetos de estudio en el contexto en que los límites políticos administrativos del estadonación ya no necesariamente coinciden con los límites sociales y culturales de las prácticas del sujeto de estudio como se suponía antes en la antropología. Sin embargo, en esta literatura se observan algunas tendencias problemáticas.

En el tercer apartado, revisaré algunos conceptos de estudios culturales, tales como, "zona de contacto" de Mary Pratt (1992), "zona fronteriza" (borderland), "transculturación", "diáspora", las perspectivas de estudios antropológicos y sociológicos del turismo y los estudios antropológicos sobre los sentimientos para poder enfocarme en la participación de la población no migrante en el proceso transnacional y en el proceso dinámico y complejo de la reconstrucción de la cultura y el lugar, y para explorar la construcción de las subjetividades de la población desplazada y las tensiones sociales y conflictos que existen dentro de los espacios sociales construidos por las conexiones transnacionales.

En el último apartado, tomando en cuenta las implicaciones de estos conceptos y perspectivas, elaboraré una metodología que llamaré seguir la imagen del terruño. Esta metodología tiene tres facetas para el análisis: la primera sugiere seguir la imagen que circula entre múltiples lugares para delinear el espacio estudiado y hacer un análisis simbólico de la imagen; la segunda propone explorar tres niveles del terruño (terruño imaginario / terruño simbólico / terruño como espacio físico) y analizar las relaciones entre tres diferentes concepciones 
del lugar; en la última, se propone revelar las relaciones de poder que están detrás del proceso de producción y el consumo de la imagen.

\section{CULTURA, ESPACIO Y SUJETO DE ESTUDIO EN LA ANTROPOLOGIA}

El término "cultura" ha sido una de las nociones claves de la antropología desde el inicio de esta disciplina. Una gran cantidad de etnografías se concentraban en la descripción y el análisis de culturas de distintas sociedades. A lo largo de la historia de la antropología, este término central se ha definido de varias maneras: un conjunto de conocimientos, creencias, artes, éticas, leyes, costumbres, y cualquiera de las otras capacidades y costumbres adquiridas por los miembros de cierta sociedad, sistema de modos de vida, sistema de ideas, sistema de significados y símbolos, etc. ${ }^{20}$ Sin embargo, a partir de los ochenta se ha cuestionado el uso convencional de este término. En estas primeras páginas del capítulo intento hacer una breve reflexión sobre este concepto, centrando la crítica en la asociación "natural" entre cultura, gente y espacio que se ha empleado tradicionalmente al definir este término, y presentar algunas propuestas nuevas que surgieron de la crisis de la antropología. ${ }^{21}$

A pesar de tanta variedad de definiciones de cultura, lo que tiene en común el uso de este término en las etnografías clásicas es que "cultura" es un sistema de modos de vida, de ideas o de significados y símbolos que comparten personas que viven en ciertos espacios que tienen limites precisos con el exterior, y por tanto, se entiende que en cada uno de estos espacios discontinuos, que se conceptualizan como aldeas, comunidades locales, sociedades y naciones, existe una cultura distinta a la cultura de otros espacios (Clifford, 1999; Gupta y Ferguson,

${ }^{20}$ En esta parte, no intento abordar todas las discusiones sobre el concepto de cultura, sino que trataré de repensarlo en relación con las prácticas espaciales de la antropología. Para revisar la historia acerca del concepto de cultura y las críticas, véase el libro de Adam Kuper, 2000, Culture: The Anthrpologists' Account, Cambridge: Harvard University Press.

${ }^{21}$ La idea de esta parte fue inspirada por los siguientes artículos: James Clifford, 1999, "Culturas viajeras" y "Practicas espaciales: el trabajo de campo, el viaje y la disciplina de la antropología", en Itinerarios transculturales, Barcelona: Gedisa; Gupta y Ferguson,1997, "Beyond "Culture": Space, Identidad, and the Politics of Difference", en Culture, Power, Place: Explorations in Cultural Anthropology, Akhil Gupta y James Ferguson (eds.), Durham, Duke University Press, pp.33-51, y George E. Marcus, 1998, "Ethnography in/of the World System: The Emergence of multi-sited ethnography", en Ethnography through Thick and Thin, Princeton: Princeton University Press. 
1997). Esta premisa no sólo se ha usado en los estudios culturales de la antropología, sino también en los estudios antropológicos sobre relaciones sociales, identidades, economía, política y religión de cierta agrupación de personas o cierta sociedad.

"Cultura" (junto con el término "identidad") se ha considerado como algo "puro" que los habitantes de esos espacios "naturalmente" discontinuos comparten uniformemente (Clifford, 1988) y, al mismo tiempo, como sistema de control que determina sus pensamientos, comportamientos y modos de vida. ${ }^{22}$ Por tanto, los "nativos" son objetos de estudio y objetos de control para la "cultura" a la vez. Son personas "transparentes" y "homogéneas" representadas por algunos informantes como portavoces y descritas por "el presente etnográfico" sin nombre propio ni subjetividad (Rosaldo, 1989). Dado que la "cultura" y los "nativos" están circunscritos dentro de los espacios, a la manera de laboratorios, los antropólogos pueden observarlos "objetivamente". Investigar en uno de esos espacios significa estudiar una "cultura genuina" y una "identidad pura" que llenan el espacio, e implica también estudiar a los "nativos" encerrados en "la cultura" y el espacio. Según esta asociación entre cultura, espacio y gente, la antropología ha dividido convencionalmente el mundo en varios espacios discontinuos, y ha considerado como objetos de estudio a "aquellos nativos" que viven fuera de los espacios en donde vivimos "nosotros antropólogos". La tarea de la antropología ha sido realizar un trabajo de campo "allá", es decir, en el espacio donde viven "ellos" y escribir las diferencias culturales entre "nosotros" y "ellos" y entre el "aquí" y el "allá".

Mientras se ha estudiado la "cultura" de cada uno de los espacios discontinuos, la antropología ha intentado analizar las relaciones entre "culturas" y "sociedades", es decir, estudiar la "cultura" de cada espacio con relación a los otros que se encuentran en el exterior del espacio estudiado. Por ejemplo, Redfield $(1941 ; 1950)$ intentó entender las relaciones entre espacios y "culturas" en términos de "folklórico / urbano", "tradicional / moderno" y "pequeña tradición / gran tradición" (little tradition / great tradition), y los teóricos del sistema mundial moderno tratan de entenderlas bajo el concepto de "centro / periferia" (Ishikawa,

${ }^{22}$ Rosaldo (1989: cap.4). 
1993). Sin embargo, dado que estas perspectivas esencialmente están basadas en las prácticas espaciales convencionales, no rompen con las distinciones binarias modernistas de "aquí / allá" y de "nosotros / ellos". Aunque los espacios se expresan de varias formas, tales como comunidades campesinas "tradicionales", sociedades urbanas "modernas", "centros", "periferias", se considera que cada uno de los espacios tiene los límites absolutos con el exterior $y$, en su interior, una "cultura", una "identidad" y relaciones sociales particulares.

La teoría de la asimilación, que intenta comprender las relaciones sociales, los comportamientos y las formas culturales de las personas que se mueven entre espacios divididos del modo convencional, también esencialmente se basa en la premisa de que existe una "cultura" en cierta sociedad o espacio. Porque, según esta idea, moverse de una sociedad a otra y vivir en el otro espacio, significa ser controlado por la cultura de ese lugar, con el tiempo, aproximarse a los habitantes de ese lugar gradualmente y teñirse con el color de esa cultura y finalmente, tener la misma identidad que ellos. Por tanto, las diferencias culturales entre espacios y sociedades no desaparecen, como tampoco desaparecen las fronteras de los espacios. El concepto de aculturación también se basa en esta idea de espacios culturales divididos. La aculturación es un fenómeno o proceso de cambio cultural que se observa en el encuentro de dos grupos de individuos que tienen culturas diferentes. A través del contacto directo y constante entre dos grupos, el patrón cultural de uno se transforma en el de otro o de ambos. ${ }^{23}$

Sin embargo, mientras se hace cada vez más intensa la circulación de gente, dinero, objetos e información que atraviesa las fronteras que dividen espacios en comunidades, sociedades y naciones discontinuas, se cuestiona este concepto antropológico tradicional de "cultura" y las prácticas espaciales ligadas a dicho concepto (Clifford, 1999; Gupta y Ferguson, 1997; Marcus, 1998). El problema de la cultura antropológica tradicional y el modo convencional de dividir los espacios es excluir primero del marco de la etnografía al sistema político y económico más

${ }^{23}$ En cuanto al concepto de aculturación, véase Redfield et al. (1935). 
amplio, que en realidad debe rodear a los espacios discontinuos y contener a varias "culturas". ${ }^{24}$

Además, al escribir del modo convencional sobre una "cultura" inherente a cierta nación, sociedad o comunidad local, se entiende que las diferencias culturales que permiten distinguir una "cultura" de otras se conforman con las fronteras que han existido siempre, y no se cuestiona cómo el marco espacial como escena de la etnografía se ha construido históricamente dentro del mundo interconectado. Al criticar esta característica de las etnografías tradicionales, Appadurai (1988) la denomina "confinamiento" o "encarcelamiento de nativo". El modo tradicional de la descripción de la cultura encierra (incluso "encarcela") a los sujetos de estudio en los espacios separados del mundo exterior y, al mismo tiempo, los "confina" en ciertas imágenes que son aplicadas uniformemente por las formas culturales descritas en la etnografía, a todas las personas que viven en ciertos espacios (Clifford, 1999; Gupta y Ferguson, 1997).

El tercer problema es que hoy en día, los antropólogos se encuentran, tanto en sus "campos" como en sus "hogares", ante varias realidades que no se pueden explicar por las distinciones de "nuestra cultura / cultura de ellos" y de "centro / periferia" mientras las personas, los bienes y la información se mueven en el nivel planetario (Clifford, 1999; Gupta y Ferguson, 1997). No es difícil buscar varios ejemplos del desdibujamiento de estas distinciones binarias modernistas en la vida cotidiana: los elementos culturales que se consideran como "nuestros" penetran en la vida cotidiana de "ellos" en el campo, y viceversa. "Ellos", quienes deberían de estar en "las periferias", viven en "los centros" (como nuestros vecinos) sin que nos demos cuenta de ello.

En cuanto a la identidad, hay varios casos en que las personas en movimiento no necesariamente forman identidades arraigadas en su origen o en su destino, sino que representan identidades descentradas, cambiantes e híbridas.

${ }^{24}$ Véase el capítulo 4 de su libro Anthropology as cultural critique: An Experimental moment in the Human Sciences, Chicago, The University of Chicago Press. En ese capítulo, Marcus y Fischer (1986) discuten sobre cómo se puede describir el sistema político y económico mundial en la etnografía. Aunque este libro y la noción de "crítica cultural" han tenido una gran influencia sobre los estudios antropológicos desde la segunda mitad de los años ochenta, no lograron salir del modo convencional de definir espacio y cultura y la dicotomía entre "aquí" y "allá" y entre "nosotros" y "ellos" (Gupta y Ferguson, 1997:42). 
Aquí también se revela el problema del modo convencional de representarlas. Por ejemplo, Paul Gilroy $(1987,1993)$ explica que las identidades de los afrocaribeños, británicos y americanos relativizan la idea de "África" como un origen único y fijo y plantean el "Atlántico Negro" como un espacio descentrado o con centros múltiples.

En gran parte de la etnografía tradicional, el investigador ha "localizado" lo que en realidad es un nexo regional / nacional / global, relegando a los márgenes los vínculos con el mundo exterior y los diversos desplazamientos de una "cultura" (Clifford, 1999:37) y, al mismo tiempo, se han excluido de la etnografía las prácticas culturales de la gente a quien no le importan mucho las fronteras que la antropología tradicional ha empleado para delimitar el "campo" y la unidad de análisis. Sin embargo, en realidad, hoy en día, no se pueden ignorar en varias escenas de la vida diaria y en el campo los encuentros con "los nativos civilizados" o "nativos no genuinos" cuyos comportamientos y prácticas culturales no encajan en ciertas imágenes sobre los grupos étnicos que los antropólogos construyeron para "confinarlos" en los mundos separados del Occidente (Chow, 1993). ${ }^{25}$ Si no modificamos el concepto de cultura y las prácticas espaciales de circunscripción de la antropología, nos encontramos ante el problema de a quiénes estudiamos y "dónde se han ido todos aquellos nativos" (Chow, 1993), y resulta que no podemos escribir la etnografía misma.

En una situación donde la cultura pierde su ancladero y los nativos que deberían permanecer en espacios separados viajan, ¿cómo puede la antropología repensar el concepto de cultura y el de identidad incluyendo en el alcance del análisis al sistema político y económico mundial y los movimientos de gente, dinero, objetos e información entre múltiples sitios? ¿Sobre qué tipo de objeto o sujeto de estudio podemos escribir en la etnografía con estos conceptos rediseñados?

En la última década, la antropología cultural, sobre todo la antropología norteamericana, ha hecho énfasis en los estudios relativos a la comunidad, la migración, la identidad y la teoría antropológica en contextos globales y

${ }^{25}$ Véase el capítulo titulado "What have all the natives gone?" del libro de Chow (1993). También véase la discusión que hace Rosaldo acerca de la visibilidad y la invisibilidad de la cultura en el capítulo 9 de Cultura y Verdad (Rosaldo, 1989: cap.9). 
transnacionales. ${ }^{26}$ Por ejemplo, la Asociación Antropológica Americana (AAA's) pronosticó en 1994 que los estudios sobre el mundo contemporáneo y los procesos de cambio global estarían entre los temas que seguirá la antropología en los siguientes 25 años (Kearney, 1995). Según Michael Kearney (1995), la globalización se refiere a procesos sociales, económicos, culturales y demográficos que tienen lugar en el interior de las naciones, pero que también transcienden los límites de la nación. En estos procesos se intensifican y expanden las relaciones sociales que eslabonan localidades distintas, de tal modo que un acontecimiento local está conformado por eventos que ocurren en otras partes del planeta y viceversa. Mientras que la "globalización" implica un proceso más abstracto, que rebasa los territorios nacionales específicos y tiene lugar en el espacio global, los procesos "transnacionales" están anclados en y transcienden uno o más estados-nación. De todos modos, en los contextos global y transnacional, una localidad está conectada con otras localidades de otros países, de tal manera que el enfoque que se limita a los procesos sociales, políticos, económicos y culturales que se dan dentro del contexto local y unidades de análisis que no tienen alcance más allá de los límites territoriales locales, regionales y nacionales produce una comprensión incompleta de "lo local".

Los años ochenta fue la década en que se hablaba de la crisis del concepto antropológico de cultura que sólo permitía a los antropólogos captar las representaciones culturales e identitarias dentro del contexto local, y que los antropólogos intentaban hacer etnografías experimentales para describir etnográficamente el sistema político económico del mundo más amplio, aquel que excedía al contexto local (Marcus y Fisher, 1986). Pero desde los años noventa, han surgido varias propuestas nuevas para la investigación etnográfica de los procesos culturales del mundo contemporáneo.

La migración, los medios de comunicación y la tecnología de la comunicación están cambiando las distancias y las fronteras, de tal manera que nuestra

${ }^{26}$ En México, cómo investigar el vínculo de lo local con lo global fue preocupación central de algunos trabajos antropológicos en los años noventa. Por ejemplo, véase el libro de Néstor García Canclini et al. (1994), De lo local a lo global: Perspectivas desde la antropología, México, Universidad Autónoma Metropolitana. 
imaginación se alimenta de tradiciones, personas, símbolos e información que pertenecían a otras partes del planeta. ¿Cómo podríamos entender y describir esta nueva realidad cultural del mundo interconectado? Ulf Hannerz (1998) critica el uso de la palabra "globalización" para describir la interconexión cultural en el mundo actual aunque hoy en día se usa con frecuencia para referirse a cualquier proceso o relación actual que atraviesa los límites de un estado-nación, dado que la mayoría de estos procesos y relaciones no se extienden a todo el globo. "El término 'transnacional' es más humilde y a menudo más adecuado para fenómenos que pueden tener una escala y distribución variable" (20). Sin embargo, por un lado, algunos procesos pueden ser más "globales" mientras que, por otro lado, las conexiones transnacionales pueden contribuir a la interconexión total. Para captar esta cualidad de la entidad como un conjunto y para referirse a "la interconexión en el mundo, a través de interacciones, intercambios y desarrollos derivados, que afectan no poco a la organización de la cultura", Hannerz propone el término "ecúmeno global" $(21,22)$

Arjun Appadurai (1996) sostiene que la nueva economía cultural global debe de ser vista como un orden complejo, disjunto y traslapado. Para analizar la complejidad de la economía global actual, Appadurai se enfoca en las disyunciones fundamentales entre la economía, la cultura y la política y propone cinco dimensiones de los flujos culturales globales. ${ }^{27}$ La primera es el ethnoscape, el paisaje de personas en movimiento y sus identidades colectivas. Éste es el caso de turistas, inmigrantes, refugiados, exiliados, trabajadores migrantes extranjeros, etc.; la segunda es el tecnoscape, los movimientos de las máquinas, tecnología e información que atraviesan las fronteras; la tercera es el financialscape, el paisaje que se compone de gran cantidad de transacciones y movimientos de dinero con gran velocidad entre países en el mercado monetario, inversiones, mercado de bolsas de valor; la cuarta es el mediascape, el paisaje compuesto de la circulación y la proliferación de las imágenes producidas y difundidas por la alta tecnología de comunicación electrónica, y la última es el ideoscape, la articulación de imágenes con las ideologías del estado-nación o las de movimientos de resistencia.

${ }^{27}$ Véase el capítulo 2 del texto de Appadurai (1996) 
Para él, la globalización no homogeneiza culturalmente el mundo por dos razones: la primera es porque existen relaciones profundamente disyuntivas entre movimiento humano, flujos tecnológicos, transferencias financieras, flujos de imágenes e ideas; la segunda es porque "estos paisajes son los fundamentos de múltiples mundos imaginados que se constituyen por las imaginaciones históricamente situadas de personas y grupos dispersos en el planeta" (33). Aunque Appadurai intenta entender el impacto cultural de la globalización a partir de las relaciones disyuntivas entre estas cinco dimensiones de los flujos globales, reconoce que en algunos casos, estas distintas formas culturales también se traslapan con otra. Appadurai propone la "macroetnografía" como un nuevo estilo de etnografía que intenta describir la tensión y negociación entre diferentes vidas y mundos imaginados y captar las características de la localidad como una experiencia vivida en el mundo globalizado y el impacto de los flujos culturales transnacional en la imaginación y las experiencias locales (1991: 196-197).

James Clifford (1999) propone reconceptualizar algunos términos antropológicos, como "identidad", "cultura", "tradición" en términos de "viaje", en vez de entenderlos en términos de "campo" que se refiere a la residencia fija en una sola localidad relativamente autónoma y separada del exterior, una localidad del tipo "aldea" como donde Malinowski realizó su trabajo de campo, y plantea el concepto de "cultura viajera". A lo que se refiere esta noción de "cultura viajera" consiste en dos modos de definir al sujeto de estudio dentro de contextos amplios en que varios sitios están interconectados. ${ }^{28}$ En primer lugar, con el término "residencia-en-viaje", Clifford propone un acercamiento a los estudios antropológicos que permite explorar los modos en que aquellas personas que se mueven entre varios sitios construyen y representan sus prácticas culturales e identidades. Sostiene que no todos los viajeros comparten la misma experiencia de viaje. Las experiencias de la gente que vive en desplazamientos espaciales varían por "género, clases, razas, localización cultural / histórica y privilegio" (op.cit: 46).

${ }^{28}$ Véase el capítulo 1 del libro de Clifford (1999). 
Sin embargo, para superar la tradición antropológica de describir a los sujetos de estudio como "nativos" confinados dentro de las comunidades locales separadas del exterior, lo que plantea Clifford no es una "nomadología" (op.cit: 52). Él agrega a la noción de cultura viajera un enfoque en el "viaje-en-residencia" como la segunda estrategia para definir al sujeto de estudio. Lo que sugiere con este término es estudiar a aquellas personas que no se mueven de su localidad, región o país dentro de un contexto más amplio, o sea, en un contexto interconectado con otros lugares, regiones y países por la circulación de otras personas, dinero, mercancías e información y fuerzas que atraviesan espacios. Por ejemplo, en sitios atravesados por turistas, por mercancías extranjeras, por señales de radio y televisión o por el Ejército, los nativos no necesariamente construyen su identidad y cultura ni constituyen su mundo de vida dentro de los contextos locales bien limitados, sino en las conexiones con otros lugares. A pesar de que no realicen un viaje en el sentido literal, pueden hacer un viaje imaginario a otros sitios al construir su identidad y cultura, o las construyen en relación con la gente y los símbolos que han desplazado (42).

Por otra parte, Marcus (1998) sugiere "la investigación etnográfica multilocal" para aproximarse a los sujetos de estudio que viven en el contexto más amplio que el local, es decir, el sistema político y económico mundial. ${ }^{29}$ Mientras las personas, los bienes y la información circulan atravesando los territorios de una comunidad local y las fronteras nacionales, las actividades de la gente, las relaciones sociales, las formas culturales y las identidades no se construyen ni se representan sólo en un sitio y un contexto local, sino en y por las conexiones entre varios sitios. Por tanto, los modos tradicionales antropológicos en los cuales se realiza el trabajo de campo en un sólo sitio durante un largo plazo (aunque nos permiten captar los procesos de la formación de cultura, relaciones sociales e identidades dentro del contexto local de ese sitio) no pueden comprenderlos con relación al exterior.

Entonces, ¿cómo se puede diseñar una investigación etnográfica en/sobre el sistema político y económico mundial? Marcus propone que el investigador mismo

${ }^{29}$ Véase el capítulo 3 del libro de Marcus (1998). 
se mueva de un sitio a otro siguiendo a los objetos de estudio. Sostiene que esta estrategia de seguir, literalmente, a la gente, los objetos, las historias de vida, las metáforas, los conflictos, moviéndose entre múltiples sitios, le permite entender cómo el mundo de vida y el espacio social de los sujetos de estudio se constituyen de asociaciones y conexiones entre varios sitios. Usando este nuevo diseño de investigación etnográfica, se pueden describir etnográficamente el contexto político y económico más amplio que rodea a los sujetos de estudio. En otras palabras, se pueden describir, desde el punto de vista de los sujetos, los espacios en donde construyen y representan su cultura, relaciones sociales e identidades, de una manera diferente del mapeo por los conceptos antropológicos convencionales de "cultura", "comunidad" y "nación", que se caracterizan por la homogeneidad, la coherencia y los límites absolutos y firmes. Por supuesto, como señalan Gupta y Ferguson, en la situación en que los sujetos de estudio están constituyendo sus espacios sociales de una manera diferente de los modos convencionales, incluso los están "reterritorializando" (1997:37), es necesario tomar en cuenta que este nuevo mapeo tiene que implementarse en términos de clase, género, raza, sexualidad, etc.

En esta nueva dirección de la disciplina o el desafío de repensar las prácticas espaciales, el sujeto u objeto de estudio, y los conceptos como cultura, comunidad, identidad, el transnacionalismo o los estudios de migraciones transnacionales han cobrado importancia para la antropología. Esta es una nueva rama de los estudios multidisciplinarios de las ciencias sociales que explora los fenómenos sociales, políticos, económicos y culturales en torno a la migración transnacional con perspectivas que atraviesan las fronteras disciplinarias de las ciencias sociales.

\section{NUEVOS CONCEPTOS DE ESPACIOS TRANSNACIONALES Y SUS LÍMITES}

Los estudios de migraciones transnacionales, por lo general, proponen, como unidad de análisis, nuevas concepciones del espacio social que se constituyen a través de la circulación constante de gente, dinero, bienes e información, que se genera en torno a la migración internacional, entre varias localidades dispersas de 
más de dos países. Se define el transnacionalismo, en términos generales, como "los procesos por los cuales los inmigrantes construyen campos sociales que eslabonan juntos su país de origen y su país de asentamiento" (Glick Schiller et al., 1992: 1). En este apartado, primero, revisaré las principales propuestas de los trabajos pioneros de esta literatura, y luego, plantearé lo que a mi juicio son sus problemas comunes entre estas.

\section{1) Circuitos migratorios transnacionales}

Roger Rouse critica a las concepciones convencionales de espacio en los estudios de migración (1991). Según él, en los estudios de la migración mexicana a Estados Unidos, han sido dominantes tres perspectivas basadas en el discurso de la modernidad. En primer lugar, el sitio de origen de los migrantes y los asentamientos se entienden como "comunidades", espacios o lugares discontiguos con límites, en donde las relaciones sociales de sus habitantes son más intensas dentro de tales espacios que afuera. Por lo tanto, la migración se define como movimiento de una "comunidad" a la otra, de un ambiente sociocultural al otro. En segundo lugar, la migración de regiones rurales de México a Estados Unidos se entiende como movimiento de la "periferia" al "centro". En el tercero, los movimientos espaciales de los migrantes de la "periferia" al "centro" significan desplazamientos de las relaciones sociales y la cultura de su origen a las otras de nuevos asentamientos. Además, se supone que la gente que se ha movido a otra "comunidad" se va a asimilar al nuevo ambiente sociocultural, por lo tanto, las fronteras y las diferencias por las cuales se distinguen una sociedad de otra no desaparecen.

Sin embargo, estas imágenes espaciales modernistas, sostiene Rouse, no son adecuadas para comprender los espacios sociales que se han constituido a través de la migración entre México y Estados Unidos. Según él, tanto el lugar de

origen como el asentamiento no son espacios discontiguos. Por ejemplo, en el caso de los migrantes aguilillenses, a pesar de que se han establecido por un largo periodo en Redwood City, California, la mayoría de ellos no han abandonado su lugar de origen, sino que siguen manteniendo los contactos con sus familiares 
en el municipio de Aguililla, Michoacán, a través de remesas, comunicación telefónica y visita temporal. En este caso, el espacio en donde sus relaciones sociales operan y se construyen no se limita solamente al lugar de origen o al de asentamiento, sino que se constituye de múltiples sitios.

Para entender este nuevo espacio social que los aguilillenses han construido, Rouse usa el término "circuitos migratorios transnacionales" (1989; 1991). Según él, a través de la circulación continua de gente, dinero, bienes e información entre el lugar de origen y nuevos asentamientos de los migrantes, se desarrollan circuitos migratorios transnacionales que constituyen una sola comunidad dispersa en una variedad de localidades. En esta nueva imagen de comunidad, tampoco son válidos la distinción espacial absoluta de "centro/periferia" y el modelo de asimilación, ya que los migrantes transnacionales han convertido los asentamientos en lugares que tienen habitantes y modos de vida identificados en la "periferia" sin perder sus diferencias culturales y lingüísticas, y al mismo tiempo, en el lugar de origen, los modos de vida de Estados Unidos y las influencias culturales extranjeras se han difundido por la televisión y la migración. Para Rouse, el nuevo espacio que se construye en este proceso transnacional es un "hiperespacio posmoderno" (Jameson, 1984), es decir, "nuevo tipo de espacio que nuestras sensibilidades modernas no pueden captar" (Rouse, 1991: 8).

\section{2) Comunidades transnacionales}

Para explorar el proceso de "latinización" de las zonas rurales de California y la creación de enclaves étnicos, Kearney y Nagengast (1989) señalan la importancia de ver como un proceso continuo la relación de migración e inmigración entre áreas en desarrollo de México y las zonas rurales de California, y proponen el concepto de "comunidad transnacional" como unidad de análisis. Las comunidades transnacionales se constituyen de redes migratorias, de lazos familiares y sociales y de vínculos económicos, políticos y culturales creados entre múltples localidades en California y México. Al teorizar sobre la comunidad transnacional, lo que proponen es un modelo de espacio alternativo a la entidad socio-espacial local que usualmente se ha llamado "comunidad" en los discursos 
funcionalista y estructuralista de las ciencias sociales. Sostienen que la comunidad transnacional es diferente de la "comunidad" entendida como "un espacio delimitado y habitado por una población coherente con relaciones sociales continuas, modo de vida compartida, una serie internamente consistente de creencias, valores y reglas que gobiernan las vidas de todos" (1). Afirman también que el "concepto de comunidad transnacional debe de entenderse, en primer lugar, en términos de componentes sociales, políticos y económicos internacionales y las relaciones de clase, pero no en un sentido espacial y ciertamente no en el sentido que "comunidad" ha sido históricamente usado en la literatura de ciencias sociales" (2).

En otros textos, Kearney explica el proceso de construcción de comunidades transnacionales desde una perspectiva posmoderna. Define el transnacionalismo como "un desdibujamiento, o, quizá, mejor dicho, un reordenamiento de las distinciones binarias culturales, sociales y epistemológicas del periodo moderno" (1991: 55). Al estudiar las comunidades mixtecas transnacionales constituidas por varias localidades en California y en Oaxaca, sobre todo las relaciones entre las organizaciones políticas indígenas y el estado-nación, Kearney sostiene que los migrantes mixtecos construyen una identidad que escapa a los discursos del estado-nación ligados a la firme distinción entre el nacional "nosotros" y el distante "ellos".

Según él, en las "áreas fronterizas" transnacionales, los mixtecos se definen como "otros", "extraños" y subalternos tanto frente a la nación mexicana como a la estadounidense. En México, ellos son "otros", diferenciados de la "nación mestiza" y destinados a la asimilación a ella y luego, a su desaparición. En Estados Unidos, son "extraños" cuya ciudadanía es negada, dado que la mayoría de ellos atraviesan la frontera norte de México sin papeles. Sin embargo, los miembros de las comunidades mixtecas transnacionales desafían sus condiciones subalternas y el poder del estado-nación, y redefinen su identidad a través de sus organizaciones políticas. El objetivo principal de estas asociaciones es defender los derechos humanos de los miembros de las comunidades indígenas en California y lograr una autonomía de las comunidades de origen en Oaxaca sin la 
intervención política del gobierno mexicano por la utilización de recursos económicos de las asociaciones de los migrantes (1991). A través de estas asociaciones se ha abierto la posibilidad de reconstruir comunidades indígenas autónomas que puedan escapar a la sujeción del estado y a la vez desafiar las condiciones subalternas que ambos Estados definen. Además, al construir un espacio relativamente autónomo y libre de los discursos del estado, ellos pueden conservar sus diferencias sociales, culturales y étnicas y reconstruir la etnicidad como identidad étnica constituida por diferencias, en vez de nivelarlas por la presión de asimilación y aculturación por parte de los estados. En suma, las comunidades transnacionales que estudia Kearney son comunidades que se consolidan en "la era del pos-nacionalismo" (1991: 55), en un momento de desvanecimiento del estado-nación.

\section{3) Campos sociales transnacionales}

Glick Schiller y sus coautoras (1992; 1995) sostienen que las concepciones convencionales de inmigrantes y migrantes ya no son suficientes para describir nuevas realidades que se están construyendo tanto en los países de origen como en los países receptores a través de la migración transnacional. La migración transnacional es el proceso por el cual los inmigrantes forjan y sostienen lazos sociales múltiples y simultáneos que conectan las sociedades receptoras con sus países de origen. En este sentido, ya no es adecuado el término inmigrante que se refería a las personas que dejan su hogar y su país de origen y se enfrentan con el proceso doloroso de incorporación a una sociedad y cultura diferente. Es mejor entender a estos nuevos inmigrantes como "transmigrantes", es decir, aquellos "inmigrantes cuyas vidas diarias dependen de interconexiones múltiples y constantes que atraviesan las fronteras internacionales y cuyas identidades públicas se configuran en relación con más de un estado-nación (Glick Schiller et al., 1992: 1-2; Glick Schiller et al., 1995: 48; Basch et al., 1994: 7).

Para describir las experiencias sociales interconectadas de los transmigrantes, estas investigadoras usan el término "campo social transnacional". Es un espacio construido por las redes familiares y múltiples lazos - sociales, 
económicos, religiosos, organizacionales y políticos - y sostenido mediante intercambios económicos y de objetos e información más allá de las fronteras geográficas, culturales y políticas (Basch et al., 1994: 7)

Aunque los transmigrantes construyen nuevos campos sociales que eslabonan las sociedades receptoras con los países de origen, atravesando los límites nacionales, Glick Schiller y sus coautoras sostienen que la construcción de los campos sociales transnacionales y la formación de identidad étnica de los transmigrantes no necesariamente están libres del poder del estado-nación, sino que han surgido como resistencia y acomodación a los procesos políticos de la nación de asentamiento y las naciones de origen (Glick Schiller et al.,1992; Glick Schiler y Basch, 1992). En el caso de los transmigrantes haitianos en Nueva York es evidente la intervención de los estados-nación en el proceso de construcción de campos sociales transnacionales y la identidad étnica. En el pasado, la identidad étnica era una identidad por la cual los grupos étnicos minoritarios resistían a los procesos hegemónicos de la nación estadounidense, una identidad alternativa a la conciencia de "gente americana" (American people) como identidad homogénea nacional que se refería solamente a la gente de piel blanca. Sin embargo, a medida que se han extendido los movimientos de los derechos civiles desde los años sesenta, la nación estadounidense ha ampliado la categoría de "gente americana". En una nueva versión de la "nación", el pueblo estadounidense se compone de una multiplicidad de poblaciones étnicas y se caracteriza por el pluralismo cultural. Por ejemplo, en este concepto, el gobierno "etnifica" a los inmigrantes haitianos como grupo étnico que forma parte del mosaico cultural del país para incorporarlos a los procesos políticos de la nación estadounidense. Al responder a este nuevo proyecto de construcción del estado-nación estadounidense, los inmigrantes construyeron las organizaciones políticas que pudieran identificarlos a ellos mismos como representantes de la "comunidad haitiana" en Estados Unidos para buscar su seguridad y sus intereses en este país.

Por el otro lado, las naciones de origen de los transmigrantes también están ejerciendo un nuevo proyecto de construcción del estado-nación (Glick Schiller et al., 1992; Glick Schiler y Basch, 1992; Basch et al., 1994). Por ejemplo, el 
presidente de Haití, al reconocer el papel importante que juegan los transmigrantes para la economía y la política del país, designó, en 1991, a la comunidad haitiana en Nueva York como el dizyem, el décimo distrito político de la nación haitiana. En otras palabras, el Estado y las élites políticas están intentando extender las fronteras nacionales para incorporar a las comunidades de los transmigrantes ubicadas geográficamente, en el sentido estricto, dentro de los territorios de otro país, a la nación de origen conformando así un "estado-nación des-territorializado" (Basch et al., op.cit.).

En resumen, lo que plantean Glick Schiller y sus coautoras es que la construcción de los campos sociales transnacionales y la identidad colectiva de sus miembros no están libres de los procesos hegemónicos del estado-nación. Los transmigrantes son sujetos creativos que construyen nuevos espacios sociales más allá de las fronteras nacionales, pero, al mismo tiempo, también son objetos del control y de nuevos proyectos del estado-nación. En el caso estudiado por ellas, tanto la nación de asentamiento como la nación de origen están redefiniendo los proyectos de la construcción del estado-nación al responder al desarrollo de las prácticas transnacionales de los migrantes. Por lo tanto, para estas autoras, el momento que Kearney llamó "la era del transnacionalismo" no es "la era del pos-nacionalismo" ni "el fin del imperio". En su caso, el transnacionalismo implica procesos continuos e intensificados de la construcción del estado-nación en la nación de asentamiento y en las naciones de origen.

\section{4) Espacios sociales transnacionales}

Para describir, categorizar y explicar los fenómenos transnacionales que se dan a través de los flujos circulares de personas, bienes, información y símbolos, la migración laboral internacional y flujos de refugiados, Thomas Faist propone el concepto de "espacios sociales transnacionales" (1999). "Los espacios sociales transnacionales son combinaciones de lazos sociales y simbólicos, posiciones en redes y organizaciones y redes de organizaciones que pueden encontrarse por lo menos en dos lugares geográficamente e internacionalmente distintos" (40). Son espacios habitados por migrantes y refugiados y residentes inmóviles en ambos 
países y constituidos por varias formas de recursos y capitales de migrantes y los residentes espacialmente inmóviles. "Aquí el espacio no se refiere solamente a sus características físicas, sino también a las estructuras de oportunidad, a la vida social y a las imágenes subjetivas, valores y significados que el lugar específico y limitado representa para los migrantes" (40). Para Faist, el "espacio" es diferente del "lugar" porque el espacio abarca y se extiende sobre varias localidades territoriales (67).

Faist explica que hay por lo menos cuatro formas ideales de espacios sociales transnacionales: 1) la dispersión y la asimilación; 2) el intercambio y la reciprocidad transnacional; 3) redes transnacionales; y 4) comunidades transnacionales. La primera forma implica el encajamiento simultáneo débil en el país receptor y el país emisor y lazos sociales y simbólicos de corta duración porque los inmigrantes en un país receptor han integrado y asimilado a la sociedad receptora. La segunda forma se caracteriza por el fuerte encajamiento simultáneo pero con lazos sociales transnacionales de corta duración. Esta forma es típica para los migrantes y refugiados de primera generación. La tercera se caracteriza por el débil encajamiento simultáneo pero con lazos sociales y simbólicos transnacionales que se mantiene, de larga duración, por negocios, políticas y la religión. La cuarta forma implica un fuerte encajamiento simultáneo en por lo menos dos países y los lazos transnacionales son fuertes y duraderos.

Estas cuatro propuestas son las concepciones principales de espacio que varios investigadores han empleado como unidades de análisis para explorar los fenómenos transnacionales que se dan en torno a la migración. Sin embargo, muchos de los trabajos de los estudios de migraciones transnacionales comparten algunas tendencias analíticas que resultan ser problemáticas a pesar de que haya diferencias en la definición de transnacionalismo y en la concepción de espacio.

1) Invisibilidad de la participación de la población no migrante en los procesos transnacionales 
La primera tendencia que quiero destacar es que numerosos trabajos de los estudios de migraciones transnacionales intentan explicar el proceso de construcción de nuevos espacios transnacionales, enfocándose solamente en aquellas personas que literalmente viajan atravesando los límites nacionales para describir cómo las prácticas sociales, económicas, políticas y culturales de estos sujetos móviles extienden y reconfiguran sus espacios de vida más allá de las fronteras nacionales. Según las concepciones de estos nuevos espacios transnacionales, los lugares de origen de los transmigrantes forman parte de estos espacios. Por tanto, los habitantes de los lugares de origen también deben de ser residentes de nuevos espacios transnacionales. Sin embargo, numerosos trabajos de los estudios de migraciones transnacionales carecen del enfoque en la población no migrante de los lugares de origen, y los puntos de vista de los residentes inmóviles y sus prácticas están excluidos del análisis. ${ }^{30}$ Esta tendencia analítica resulta ser problemática, dado que nos da la impresión de que esta nueva perspectiva limita el privilegio de crear un nuevo modo de vida, una nueva realidad e identidad en el espacio transnacional sólo a los migrantes. En consecuencia, la gente que se queda en los lugares de origen que forman parte de ese espacio aparece como miembro secundario e incluso invisible.

Es lógico que los estudios de migraciones transnacionales tiendan a analizar tales nuevos espacios poniendo tanto énfasis en los migrantes, ya que los espacios transnacionales que se investigan se han formado principalmente a raíz de la migración transnacional. No obstante, el problema es que los análisis sobre los espacios transnacionales solamente a partir de las acciones y los puntos de vista de los migrantes excluyen de la discusión visiones del mundo y actividades creativas de otros habitantes que viven en el contexto transnacional sin cruzar las fronteras nacionales físicamente.

En este sentido, en los estudios de migraciones transnacionales es dominante la primera estrategia que propone Clifford para estudiar conexiones

${ }^{30}$ Es cierto que Glick Schiller y sus coautoras (Glick Schiller et al.,1992; Glick Schiler y Basch, 1992) prestan atención a los lugares de origen de los transmigrantes, pero, sólo explican las perspectivas del gobierno y las elites de las naciones, no los puntos de vista de los habitantes de las localidades de donde los transmigrantes han salido. 
entre múltiples sitios: "residencia-en-viaje". Sin embargo, como he mencionado, las "culturas viajeras" que él plantea no son una estrategia solamente para analizar a la gente en movimiento, sino también implica el "viaje-en-residencia", una estrategia para enfocarse en la gente inmóvil que desplaza sus modos de vida, cultura, identidades, relaciones sociales y el mundo de vida a través de los encuentros con la gente, bienes e información en movimiento y las conexiones con otros lugares a pesar de no realizar un viaje en el sentido literal.

En la etnografía tradicional, los sujetos que atraviesan los límites de los espacios discontinuos han sido excluidos de la etnografía o relegados a los márgenes del marco etnográfico. Los estudios de migraciones transnacionales desafían esta tradición antropológica, rompen con la asociación "natural" entre cultura, espacio y gente y proponen nuevas perspectivas para investigar los espacios, enfocándose en la gente que atraviesa los límites espaciales convencionales. Pero, ahora, irónicamente, resulta que las personas que no están en movimiento, o sea, aquellos que han sido descritos como "nativos" en la etnografía tradicional, son invisibles.

\section{2) Espacios con la armonía social}

La invisibilización analítica de la población no migrantes en los procesos transnacionales nos conduce al segundo problema de esta literatura: los espacios que se construyen alrededor de la migración transnacional son vistos como espacios con la unidad y la armonía social que están lejos de tener tensiones y conflictos internos, dado que no se explican cómo influyen las prácticas transnacionales de los migrantes sobre su relación con los habitantes de sus localidades de origen y de qué manera estos residentes inmóviles perciben y expresan la presencia de los migrantes en los lugares de origen. Si no hay descripción de intereses y visiones diferentes de lo que representan los migrantes, es difícil captar el problema de la desigualdad y las relaciones asimétricas de poder entre los lugares de origen y los asentamientos y entre los habitantes de los terruños y los migrantes dentro de las conexiones transnacionales, y es difícil 
también entender de qué manera contribuyen una y otra parte en el proceso. Incluso, estos espacios aparecen como espacios homogéneos.

En los casos de la migración mexicana hacia Estados Unidos, es cuestionable plantear que en los procesos transnacionales se estén construyen espacios homogéneos, armónicos socialmente, dado que en varios estudios de casos sobre el retorno temporal de los migrantes se han reportado tensiones sociales y contiendas que se generan entre los habitantes de las localidades de origen y los migrantes. Generalmente el retorno de los migrantes a sus lugares de origen en México durante la temporada de fiestas se ha entendido como una ocasión para la vinculación y estrechamiento de relaciones entre la gente que se queda en ese lugar y la población que ha salido a otro país (Durand, 1994: 319) o como una oportunidad de revalidación de su membresía en las comunidades locales (Lopéz y Cedestrom 1991) aunque también Goldring (1997), Montes (1992) y Espinosa (1999) nos alertan sobre los aspectos conflictivos del retorno. ${ }^{31}$

Por un lado, Goldring (aunque se enfoca solamente en los migrantes) afirma que la fiesta en el pueblo de Las Ánimas (en el sur de Zacatecas) permite a los trabajadores migratorios gastar y generar dinero a favor del desarrollo de la comunidad local; que la fiesta es "una celebración e identificación importante de la pertenencia al pueblo", y que la fiesta "proporciona un contexto que permite tanto a los trabajadores migratorios como a los habitantes no migrantes alternar y renover los lazos" (Goldring, 1997:80). Por el otro lado, Goldring considera también que el retorno es una ocasión en que los migrantes y sus familias "puedan exhibir su poder de consumo y afirmar la distinción social" entre las demás personas con quienes comparten un sentido identitario de la comunidad (1997:90).

Olga Montes (1992), quien estudia los impactos de la migración a los Estados Unidos en una comunidad del estado de Oaxaca, señala que al regresar del Norte, los migrantes han desplazado del sistema de cargos a los lugareños que tienen el poder económico (que se deriva del comercio local y regional). Al regresar con recursos económicos que han ganado en el otro país, los migrantes disputan la

${ }^{31}$ Durand (1994) analiza la función de las fiestas religiosas en el occidente de México, sobre todo las fiestas en Los Altos de Jalisco en una sección del capítulo siete. 
mayordomía y el poder político en la comunidad de origen a la élite tradicional del pueblo.

Espinosa (1999) analiza los procesos históricos y socioculturales de la creación del día del emigrante, una nueva ceremonia religiosa de la iglesia católica en el pueblo de San Diego de Alejandría en los Altos de Jalisco. Señala que anteriormente la iglesia católica local se preocupaba por el regreso de los migrantes y los rechazaba considerándolos como causantes de la mayoría de problemas sociales en el pueblo, ya que regresaban con demasiado dinero y con ideas y comportamientos que chocaban con los valores y las prácticas del catolicismo. Sin embargo, cuando el número de los habitantes que salían a los Estados Unidos aumentó y el papel económico, político y cultural que jugaban los migrantes en el pueblo de origen se incrementó, la iglesia tuvo que cambiar esta actitud negativa hacia los migrantes. En este contexto, creó este nuevo ritual para incorporar a los migrantes tanto a la iglesia como a la comunidad de origen.

Otras prácticas de los migrantes que hacen patente su presencia en las localidades de origen también producen tensiones sociales. Por ejemplo, Goldring señala que la inversión de los dólares que los migrantes han ganado en Estados Unidos en proyectos colectivos de la comunidad local (como en la construcción de edificios escolares, la restauración de la iglesia, la pavimentación de caminos, etc.) no es ajena a los conflictos (1997: 86-89). A veces, los proyectos colectivos de la comunidad local costeados con recursos movilizados por los migrantes generan algunas interrogantes: ¿a quién benefician más, a los migrantes o a los habitantes del pueblo que no emigran?

Como lo indican estos casos, la reincorporación de los migrantes en los lugares de origen; la negociación de su pertenencia a través del retorno y de la participación en las fiestas de las comunidades de origen; los vínculos entre las sociedades receptoras y los lugares de origen; y las relaciones entre los migrantes y la población no migrante; no se pueden leer simplemente como redes sociales transnacionales o circuitos por donde pasan la gente, dinero, objetos e información, sino que deben leerse también como relaciones de poder. 


\section{3) Conexiones transnacionales y diferencia cultural}

A pesar de que haya diferentes posiciones para denominar, teorizar y aproximarse a los nuevos espacios sociales de los migrantes, los conceptos espaciales que he revisado anteriormente tienen algunas características comunes: 1) La extensión de las relaciones sociales más allá de las fronteras nacionales es el aspecto social que ha llamado la atención de muchos investigadores. De hecho, una parte importante de los estudios de migraciones transnacionales se centra en el análisis de las redes sociales para ilustrar los espacios, tales como, circuitos migratorios transnacionales, espacios sociales transnacionales, campos sociales transnacionales; 2) La circulación de gente, dinero, objetos, símbolos e información entre las sociedades receptoras y las localidades de origen es la segunda característica. Para demostrar empíricamente la existencia de un fuerte vínculo, aparte de las conexiones sociales, entre los asentamientos y los lugares de origen los flujos transnacionales han sido estudiados más que las personas y las cosas que no se mueven; 3) Otra novedad de estos nuevos espacios sociales de los migrantes señalada por muchos investigadores es la continuidad en las prácticas sociales y culturales de las sociedades de origen de los migrantes y el mantenimiento de las identidades locales, nacionales o étnicas en las sociedades receptoras. Varios investigadores han utilizado los términos, tales como, "mexicanización", "latinización", la infiltración de la "periferia", para describir el hecho de que los migrantes no se asimilan a la cultura dominante de la sociedad receptora y construyen un ambiente social y cultural diferente del entorno sociocultural dominante de la sociedad receptora pero similar al de su país de origen (Massey, 1995; Kearney y Nagengast, 1989; Rouse, 1991); 4) Aparte de las prácticas de los migrantes, las instituciones políticas, sociales y religiosas que intervienen en la construcción y fortalecimiento de los vínculos entre los países receptores y los emisores han sido objetos de estudio en algunos trabajos; 5) Resumiendo todas estas características, los investigadores que proponen nuevas concepciones de espacios sociales construidos en los procesos transnacionales hacen énfasis en la reducción de la distancia social entre los países receptores y los emisores a pesar de la distancia geográfica con los lugares de origen y la 
dispersión geográfica de los migrantes. La simultaneidad en la comunicación, la toma de decisión y la participación social y política de los migrantes en ambos países es la noción que se usa en muchos trabajos para explicar esta característica de la reducción de la distancia social.

Para muchos investigadores, el principal objetivo del señalamiento de estas características es plantear nuevas concepciones espaciales que rompen con las formas territorializadas de entender las realidades sociales y que permiten salir de las perspectivas analíticas centradas en la nación y su aparato conceptual que han categorizado al sujeto de estudio y delimitado el espacio de su vida con las fronteras políticas administrativas. Pero, estas características de los espacios sugieren nuevas preguntas: ¿Cómo se (re)construyen la cultura y el lugar en estos nuevos espacios? ¿Qué papel juegan los lugares dentro de esta nueva entidad social? ¿Se construyen los lugares de manera culturalmente homogénea? ¿Por qué tienen los mismos paisajes o similares? ¿Cómo manejar el término diferencia cultural junto con las conexiones transnacionales? ¿La diferencia cultural sólo existe entre los nuevos espacios transnacionales y el "exterior", no existe dentro de los mismos espacios?

Otro problema de los estudios de migraciones transnacionales que quiero señalar con esta breve revisión es que estos nuevos conceptos de espacio transnacional en realidad son tan abstractos y ambiguos para el análisis de la formación cultural en los procesos transnacionales que no nos ayudan al esclarecimiento de los procesos culturales y a menudo nos dan la idea de homogeneización cultural.

$\mathrm{Si}$ revisamos con atención la relación entre el espacio, las conexiones transnacionales y el lugar en los nuevos conceptos planteados por los investigadores pioneros de los estudios de migraciones transnacionales, podemos encontrar una nueva asociación "natural" del espacio. Por ejemplo, Faist (1999), al definir los espacios sociales transnacionales, explica la relación entre el lugar, espacio y gente de este modo: El espacio "es diferente del lugar en que abarca o se extiende sobre varias localidades territoriales" (67). El espacio "no se refiere solamente a sus características físicas, sino también a las estructuras de 
oportunidad, a la vida social y a las imágenes subjetivas, valores y significados que el lugar específico y limitado representa para los migrantes" (40). Los espacios sociales transnacionales son una combinación de lazos sociales y simbólicos y redes de organizaciones y son espacios habitados por los migrantes, refugiados y la población inmóvil en los países receptores y los países de origen.

En realidad, lo que Faist denomina espacios sociales transnacionales son las redes o conexiones sociales, económicas, organizacionales, políticas y simbólicas entre distintos lugares, las cuales se analizan básicamente enfocándose en los sujetos y sus acciones. Esta confusión de las redes con el espacio o la asociación "natural" entre redes y espacios también es evidente en otro concepto, el de "campos sociales transnacionales". El campo social transnacional también es un espacio construido por las redes y múltiples lazos sostenidos mediante la circulación de gente, dinero, objetos, símbolos e información entre los países receptores y los países de origen de los migrantes. El problema es que aquí los investigadores no aclaran si hay heterogeneidad o diferenciación social dentro de esta nueva entidad social, de tal modo que da la impresión de que existe una cultura y las personas tienen una identidad dentro de esta nueva entidad social que simplemente ahora no está delimitada por las fronteras nacionales. Así, la cultura de la localidad de origen o la cultura de la sociedad receptora se homogeniza en estos espacios porque se plantea la existencia de una especie de sistema de valores y significados y sistema de redes sociales dentro de los mismos espacios (aunque las descripciones etnográficas reportan que en los asentamientos hay representación cultural e identitaria arraigada en sus sociedades de origen, y al mismo tiempo, en los lugares de origen las influencias culturales de las sociedades receptoras se difunden).

Según los conceptos espaciales de los estudios de migraciones transnacionales, se considera que tanto los habitantes como la población no migrante de los lugares de origen habitan los mismos espacios sociales. Pero a pesar de que existen las conexiones entre distintos lugares, puede ser que no todos los sectores de la población compartan la vida social, la imagen subjetiva, los valores y los significados. Por ejemplo, aunque hay conexiones simbólicas 
entre dos lugares mediante la circulación de objetos, esto no significa que toda la población inmóvil comparte el sistema de significados con los migrantes. Faist mismo reconoce que hay diferentes concepciones de espacio y que los espacios se refieren a sus características físicas, la vida social, el imaginario, los valores y significados. Pero no menciona que estas distintas concepciones de espacio aún podrían variar dependiendo de las experiencias, el género, la generación y la clase. A mi juicio, Faist confunde la percepción de espacio del investigador con las percepciones de espacio del sujeto de estudio.

El concepto de comunidad transnacional de Kearney y Nagengast (1989) es más explícito en este aspecto. Ellos diferencian el concepto de comunidad transnacional del concepto clásico de "comunidad" entendida como "un espacio delimitado y habitado por una población coherente con relaciones sociales continuas, modo de vida compartida, una serie internamente consistente de creencias, valores y reglas que gobiernan las vidas de todos" (1). Pero, se cuestiona qué tan pertinente es seguir usando el término "comunidad" para conceptualizar una entidad social transnacional que no tiene mucho que ver con las características fundamentales del concepto original, es decir, cuáles elementos son factores importantes para que distintos sectores de la población se integren como miembros de una comunidad a pesar de la heterogeneidad y la diferenciación interna.

En mi opinión, este problema de los conceptos de espacio, que no están elaborados para incluir tales términos como heterogeneidad y diferencia cultural, tiene que ver con dos perspectivas que se esconden en los estudios de migraciones transnacionales. En primer lugar, aunque los teóricos de los estudios transnacionales han presentado una crítica valiosa de las ideas simplistas sobre la "asimilación" señalando la manera en que fuertes vínculos sociales, los viajes frecuentes y la comunicación constante facilita la construcción y mantenimiento de nuevos espacios sociales e identidades sociales que atraviesan la frontera, estas aproximaciones tienden a subestimar los contrastes reales en el contexto social entre el país de origen y el país receptor (Park, 2002: 176) y el papel que juegan los lugares en los procesos transnacionales. Incluso, esta perspectiva que presta 
poca atención a los detalles de las diferencias y contrastes entre los lugares dentro de los nuevos espacios corre el riesgo de plantear estos espacios como espacios culturalmente homogéneos. Entonces, podríamos cometer el error de suponer que el proceso transnacional en la dimensión cultural es un proceso homogeneizador.

En segundo lugar, algunos investigadores no sólo manejan los nuevos conceptos espaciales como instrumentos analíticos para entender nuevas realidades socioculturales en los procesos transnacionales, sino que "reifican" los conceptos y confunden los modelos con las realidades. Federico Besserer (2004) advierte esta tendencia del siguiente modo:

La idea detrás del concepto de espacio transnacional es que estos espacios son "reales" en tanto son el resultado del flujo objetivo, es decir, observable, de símbolos, objetos, personas o valores [...] A mi parecer, la aproximación anterior corre el riesgo de "cosificar" o "reificar" los conceptos o instrumentos analíticos que el investigador ha usado precisamente como instrumento $o$ artefactos que median entre el proceso de conocimiento y la realidad que se pretende conocer. El caso extremo es aquel en el que se ha llegado a plantear el carácter "natural" de las "redes sociales transnacionales" argumentando que éstas se basan en lazos familiares o "de sangre". ${ }^{32}$

En otro texto, Besserer (1999), al proponer el transnacionalismo de ruptura ontológica, también critica a aquella perspectiva de los estudios de migraciones transnacionales, que denomina el "transnacionalismo objetivista" o el "empirismo transnacional". Los estudios de esta perspectiva tratan de aprehender las prácticas espaciales transnacionales con nuevos conceptos que reflejan los datos empíricos para hacer un rompimiento con las formas territorializadas de entender las realidades sociales difundidas en las ciencias sociales; pero, lo hacen sin salir del marco de los cánones clásicos del análisis cultural que se basa en el objetivismo. ${ }^{33} \mathrm{Sin}$ embargo, esta perspectiva objetivista corre el riesgo de "reificar" los conceptos y puede marginar el punto de vista privilegiado de quienes viven sus vidas desde la transnacionalidad. Como ejemplo de la distancia ontológica entre el

\footnotetext{
${ }^{32}$ Besserer (2004: 20,21).

${ }^{33}$ Véase Renato Rosaldo, 1989, Cultura and Truth: The Remaking of Social Análisis, Boston: Beacon Press.
} 
sujeto y el objeto de estudio en los estudios transnacionales objetivista, Besserer critica la aplicación del concepto de comunidad transnacional que hacen Glick Schiller y Fouron (1990) para los afrocaribeños-estadounidenses y su rechazo del uso del concepto de "diáspora" que esta población estudiada ha usado. Para él, "la observación, experiencia y representación del sujeto de estudio desde los 'márgenes' de la disciplina" pero "desde dentro de la comunidad transnacional", pueden aportar un mejor "punto de vista" que el del observador disciplinado por los cánones clásicos del análisis social (Besserer, 1999: 216). A partir de los estudios culturales, estudios subalternos y estudios postcoloniales, este investigador plantea una perspectiva que propone un rompimiento con la epistemología disciplinaria tradicional.

Mi postura acerca de estas discusiones sobre los procesos de construcción de las conexiones transnacionales y la formación cultural es que en primer lugar, los procesos transnacionales no son procesos culturalmente homogeneizadores, sino que son procesos de construcción de espacios heterogéneos en donde existen diferentes modos de interpretación y de construir y vivir los espacios y diferentes posicionamientos de los sujetos dentro las redes de fuerzas económicas y políticas que articulan las localidades que forman parte de las conexiones transnacionales. En segundo lugar, a pesar de que las prácticas y las relaciones sociales de los migrantes y sus familias atraviesan las fronteras nacionales y construyen espacios de vida más allá de la frontera, los contrastes reales en el contexto social entre el país de origen y el país receptor siguen existiendo y siendo un factor importante para construir la diferencia cultural. En mi opinión, la construcción y la representación de la cultura local de lugares de asentamiento y la del "lugar de origen" no se deben entender con una simple explicación de que hay dos culturas muy similares y quizá iguales en dos países, dado que son construidas por la misma población, los mismos elementos y las mismas relaciones sociales en diferentes lugares. Si entendemos de este modo el proceso de construcción de la cultura en las localidades que forman parte de los nuevos espacios transnacionales, no alcanzamos a ver los detalles de procesos dinámicos internos. 
En cuanto a las discusiones sobre la perspectiva objetivista de los estudios transnacionales, estoy de acuerdo con Besserer en que es importante reconocer la distancia ontológica que existe entre las narraciones de los sujetos que viven dentro del proceso transnacional y la observación que hace el investigador objetivista. En este aspecto, los sentimientos son uno de los cortes de análisis importantes que algunos antropólogos sugieren para hacer una ruptura con el objetivismo del análisis social y cultural, dado que parte del punto de vista de los sujetos que viven en cierta situación social y cultural estudiada para entender el proceso social y cultural (Marcus y Fischer, 1986; Rosaldo, 1989; Besserer, 2004). Explicaré este enfoque en los sentimientos en el siguiente apartado.

En el caso de migraciones transnacionales entre México y Estados Unidos, la nostalgia es un sentimiento interesante que revela la distancia ontológica en los estudios de migraciones transnacionales. Por un lado, estas migraciones transnacionales han sido estudiadas por el uso de nuevos modelos de espacio transnacional que hacen énfasis en la reducción de la distancia social entre el país receptor y el país de origen y la continuidad y el mantenimiento de las prácticas sociales y culturales de las localidades de origen en el país receptor. Por otro lado, muchos investigadores han señalado y observado las manifestaciones constantes de este sentimiento hacia el origen entre los migrantes mexicanos. Por ejemplo, al sintetizar los principios básicos de los procesos migratorios del occidente de México a Estados Unidos, Massey y sus coautores señalan que aunque los migrantes mexicanos se dirigen hacia el Norte por razones económicas, alargan su estancia y se establecen en ese país, "retienen un fuerte apego sentimental a su terruño, lo cual se expresa en una ideología muy pronunciada que favorece y legitima la migración de retorno", y que las redes de relaciones sociales entre la sociedad receptora y las comunidades de origen se mantienen mediante el proceso de emigración y retorno (Massey et.al.,1991: 15). Asimismo, Víctor Espinosa (1998), quien analiza el dilema de retorno que manifiestan los migrantes mexicanos, enfocándose en una familia originaria de una localidad de los Altos de Jalisco, también observa las manifestaciones de una fuerte nostalgia que provoca el separarse del lugar de origen y la persistencia de un arraigado sentido de 
pertenencia en las narraciones de los migrantes, y sostiene que la tensión constante entre el establecimiento y el retorno "ha jugado un papel primordial en el reforzamiento de los lazos que unen en un solo espacio transnacional los lugares de origen y destino de los migrantes" (Espinosa, 1998: 44).

Aquí, encontramos un problema grande entre la realidad etnográfica observada por algunos investigadores y lo que proponen los modelos de nuevos espacios transnacionales: si no existen la diferencia cultural, el contraste y la distancia mayor entre el lugar de origen y los asentamientos dentro de los nuevos espacios, no debería de existir esta subjetividad sobre el lugar de origen, dado que la nostalgia es un estado de ánimo relacionado con el hogar, la tristeza y el malestar por la causa de la distancia y la diferencia entre el lugar, donde se encuentra el sujeto actualmente, y el hogar o el terruño, donde pasó su infancia y juventud con su familia y otras personas cercanas. El señalamiento de algunos investigadores sobre la manifestación de la nostalgia entre los migrantes mexicanos podría explicar el motivo por el cual los migrantes construyen y refuerzan el vínculo transnacional. Pero, esto no nos aclara por qué siguen existiendo las narrativas de este sentimiento hacia sus lugares de origen a pesar de que la construcción de las conexiones transnacionales entre el país receptor y las localidades de origen no es un proceso reciente en muchos casos. Para resolver esta contradicción entre la realidad etnográfica y los instrumentos analíticos, como propone Besserer (1999), es necesario construir una perspectiva que haga un rompimiento con la epistemología disciplinaria tradicional y permita analizar los espacios desde un ángulo distinto.

En el siguiente apartado, tomando en cuenta estos problemas teóricos de los estudios de migraciones transnacionales, revisaré algunos conceptos y discusiones de otros géneros de estudios sobre el viaje y de los estudios antropológicos sobre los sentimientos para incluirlos en el marco teórico y la metodología que armaré en este capítulo. 


\section{NUEVAS PERSPECTIVAS PARA EL ANÁLISIS CULTURAL DE LOS PROCESOS TRANSNACIONALES}

Vertovec (2003) sostiene que podría ser útil analizar las migraciones transnacionales con los conceptos y aproximaciones que se han desarrollado en otros campos de estudio para describir otra formación social transnacional. Denomina a esta perspectiva multidisciplinario como "interpolinización transnacionalista" (Cross-fertilizing transnationalism). Aunque hay numerosas limitaciones a este tipo de ejercicio, la aplicación de términos y conceptos prestados de otros campos de estudio en el análisis de las migraciones trasnacionales podrían servir como artefactos e instrumentos inspiradores para reordenar y ver de una forma alternativa los datos de grupos específicos de migrantes transnacionales (Vertovec, 2003: 643-645). Siguiendo esta idea, aquí revisaré algunos conceptos y aproximaciones surgidos de otros campos de estudios sobre el viaje para describir los espacios que se constituyen a través del desplazamiento y encuentro de distintas poblaciones. Seleccioné aquí conceptos, tales como, "zona de contacto", "zona fronteriza", "transculturación", "espacio diaspórico", la aproximación del proceso de construcción del espacio en los estudios antropológicos y sociológicos del turismo y los estudios antropológicos sobre los sentimientos, con el interés de introducir en los estudios de migraciones transnacionales nuevas propuestas acerca de la relación entre el desplazamiento, el espacio, el sujeto de estudio y la cultura.

\section{1) Zona de contacto}

Al estudiar cómo fueron recibidos y apropiados por los colonizados y grupos subordinados los modos en que los dominantes y colonizadores representan la colonia y su cultura, Pratt (1992) usa el término "zona de contacto" (contact zone). Este concepto se refiere "al espacio en donde poblaciones, geográfica e históricamente separadas entran en contacto una con otra, y establecen usualmente relaciones continuas, incluyendo coerción, desigualdad radical y conflicto incontrolable" (6). 
Aunque su uso de los términos "contacto" y "metrópoli / periferia" podría ser confundido con la idea del contacto entre "culturas" con límites espaciales absolutos, el objetivo principal del uso de este concepto es hacer hincapié en el siguiente punto: "de qué modo están constituidos los sujetos en y por sus relaciones recíprocas. Se trata de las relaciones entre colonizadores y colonizados, o viajeros y "viajados" ("travelees"), no en términos de separación o apartamiento, sino en términos de copresencia, interacción, entendimientos y prácticas trabadas, a menudo dentro de relaciones de poder radicalmente asimétricas" (7).

Esta perspectiva es sugerente, no sólo para ver las relaciones entre colonizadores y colonizados y entre los estados que poseían la soberanía de la colonia y los estados recientemente independizados de tales colonias, sino también para explorar relaciones entre dominantes y subordinados en "situaciones pos-coloniales". El término "situación pos-colonial" se refiere a la situación en que se constituyen las relaciones inequitativas, conflictivas y discriminatorias entre dominantes y subordinados dentro de una nueva nación recientemente independizada de la metrópoli colonial. Esta situación no solamente se observa en el nivel nacional, es decir, en relaciones entre las elites del gobierno de la nación y el pueblo en general, sino también en niveles micros, por ejemplo, en relaciones entre las elites y los demás habitantes de una comunidad local (Maeyama, 1994).

Este concepto de "zona de contacto" abre la posibilidad de considerar que los lugares, regiones y países entre los cuales circulan gente, mercancía, símbolos, información e ideas no son espacios homogéneos, sino espacios heterogéneos donde hacen contacto las personas, objetos, símbolos e ideas derivados de múltiples lugares bajo una relación de poder asimétrica entre los viajeros y la población inmóvil.

\section{2) Zona fronteriza}

Por su parte, Alvarez (1995) propone una antropología de los así llamados borderlands y explica qué tipo de zona de contacto son los nuevos espacios sociales y culturales que se han construido entre México y Estados Unidos en los procesos transnacionales. Esto lo hace a través de una revisión de los trabajos de 
la antropología aplicada sobre regiones fronterizas y los trabajos etnográficos y sociológicos sobre la migración mexicana a Estados Unidos y sobre los procesos fronterizos.

"Zona fronteriza" (borderland) se refiere a la región y una serie de prácticas definidas y determinadas por la frontera que se caracterizan por el conflicto y la contradicción (1995: 448). Según Alvarez, la frontera entre México y Estados Unidos ha sido un modelo o un icono de los estudios de frontera y de zonas fronterizas. Sin embargo, en su propuesta, el término frontera no sólo se refiere a la línea de 2000 millas que divide estos dos países ni un simple límite impermeable que separa y delimita geográfica y territorialmente comunidades y culturas, sino una metáfora o una extensión conceptual de esta frontera.

Aunque su propuesta comparte con algunos pioneros de los estudios de migraciones transnacionales la intención de cuestionar los conceptos convencionales de "comunidad" delimitada con los límites territoriales absolutos y enfocarse en los comportamientos e identidades cambientes y la reconfiguración de relaciones sociales, Alvarez considera a los borderlands como una zona de contacto caracterizada por la contradicción, la paradoja y el conflicto, así como la diferencia y el contraste.

\section{3) Transculturación}

Hirabayashi (2002) sostiene que el concepto de transculturación ofrece una nueva perspectiva sobre el cambio cultural que se ha dado en el continente americano en la era de la globalización que se caracteriza por la circulación constante de gente, ideas y objetos y los encuentros entre poblaciones culturalmente diferentes e históricamente separadas y/o conectadas. El término "transculturación" originalmente fue elaborado por el antropólogo Fernando Ortiz para captar la importancia de la conquista y la colonización y la dinámica de proceso de cambio cultural a través del contacto entre poblaciones diferentes en una relación de poder asimétrica. ${ }^{34}$ Para, Ortiz, los términos de la antropología

${ }^{34}$ Fernando Ortiz, 1995, Cuban Counterpoint: Tobacco and Sugar, Durham, Duke University Press. Este texto fue publicado originalmente en español en 1940. 
tradicional, tales como, "difusión," "aculturación," "asimilación," no pueden explicar la complejidad de la experiencia cubana. Según él, hay dos momentos o procesos diferentes en la historia del cambio cultural en Cuba que fue afectada por el colonialismo y el imperialismo: por un lado, se observa el proceso que se podría denominar "deculturación", es decir, la destrucción y la pérdida de la cultura de aquellos grupos subordinados; por el otro lado, hay un proceso de creación de nuevas formulaciones culturales a través de la mezcla y yuxtaposición de personas y elementos culturales diferentes. Este proceso podría llamarse "neoculturación." La transculturación es un concepto que intenta captar la dinámica de estos dos procesos.

Hirabayashi señala algunas ventajas del concepto de transculturación: en primer lugar, es un concepto que reconoce las bases históricas del poder y las relaciones de poder que están detrás del contacto cultural; en segundo, al enfocarse en la parte creativa del proceso de cambio cultural, el análisis va más allá de una simple descripción de victimización o imposición de una cultura dominante sobre el grupo subordinado; y por último, el concepto puede analizar procesos del cambio cultural más contingentes y dinámicos que los patrones del cambio linear que se suponían en los conceptos de aculturación y asimilación (2002: xiii, xiv).

\section{4) Identidad y espacio diaspórico}

Entonces, ¿de qué modo se representan las identidades en este tipo de espacios de encuentro entre poblaciones distintas y de contacto con diferentes elementos culturales? En las dos últimas décadas el término "diáspora" como teoría cultural ha enriquecido esta discusión. Aunque hoy en día este término se ha empleado muchas veces, para referirse a una variedad de categorías de personas desplazadas (tales como, expatriados, refugiados, residentes extranjeros, inmigrantes y grupos étnicos y raciales, por lo general), hay dos maneras diferentes de definir la diáspora: La primera es la definición de diáspora como un grupo de personas que se han dispersado a partir de un centro original hacia varios puntos, conservando una memoria, una visión y un mito acerca de su origen 
y considerando el hogar ancestral como un lugar de regreso final (Safran, 1991). Por otro lado, los teóricos de los estudios culturales, como, Stuart Hall (1990), Paul Girloy (1987) y Avtar Brah (1996) critican a esta definición basada en la idea centrada en un origen fijo y usan este término como un concepto que hace un rompimiento con los discursos esencialista del estado-nación. Por ejemplo, para Hall (1990), la diáspora "no se refiere a aquellas tribus dispersas cuya identidad sólo puede obtenerse en relación con alguna patria sagrada adonde ellas deben de regresar a toda costa" (235). En cuanto a la identidad, la forma identitaria que critica es una identidad fija que consiste en uniformidad y homogeneidad. La típica de esta forma identitaria es la identidad nacional. En cambio, Hall plantea una identidad alternativa, es decir, la que no es fija ni se basa en un origen esencial, sino que es fluida y se llena de diferencias culturales y discontinuidad cultural. Es una identidad que reconoce la heterogeneidad y la diversidad que siempre existen entre individuos. Hall define a esta identidad como "identidad diaspórica".

En esta idea descentrada sobre las diásporas, las raíces de una diáspora se consideran como las rutas para construir esferas públicas alternativas, formas de conciencia y solidaridad comunitaria que mantienen identificaciones fuera del tiempo y espacio nacional y reconocen diferencias y heterogeneidad (Gilroy, 1987). Por su parte, Brah (1996) propone el concepto de "espacio diaspórico" y sostiene que estas formas identitarias no son privilegios de las diásporas.

El espacio diaspórico es la interseccionalidad de diáspora, frontera y des/locación como un punto de confluencia de procesos económicos, políticos, culturales y psíquicos. Es donde las múltiples posiciones de los sujetos están yuxtapuestas, contendidas, proclamadas o negadas; donde lo permitido y lo prohibido se interrogan perpetuamente; y donde lo aceptado y lo transgresivo imperceptiblemente se mezclan aun cuando estas formas sincréticas estén negadas en el nombre de la pureza y la tradición. Aquí, la tradición misma es inventada continuamente aun cuando fuera aclamada como la tradición surgida de las neblinas del tiempo. Lo que está en juego es la experimentalidad infinita, la miríada de procesos de fisura y fusión cultural que subscriben formas contemporáneas de identidades transculturales [...] Mi argumento es que el espacio diaspórico como una categoría conceptual es "habitado", no sólo por aquellos que han migrado y sus descendientes, sino igualmente por aquellos que son construidos y representados como originarios del lugar. En otras palabras, el concepto de espacio diaspórico (como opuesto al de 
diáspora) incluye el enmarañamiento y el entrelazamiento de genealogías de dispersión dentro de aquellos que "permanecen alli". ${ }^{35}$

Lo interesante de esta propuesta es que aquellas personas que no hacen el viaje en el sentido literal también pueden construir las identidades y las prácticas transculturales a través de las conexiones con otros lugares y contacto con aquellos que viajan.

\section{5) Conexiones translocales, cultura y diferencia en el turismo}

La definición del concepto de turismo como objeto de estudio es una tarea difícil porque existen una diversidad en las actividades de los turistas y variedad en los intereses de estudio y porque el turismo se ha estudiado por varias disciplinas académicas, tales como, los estudios de mercadotecnia, sociología, historia, antropología, los estudios culturales, semiología y los estudios de medios de comunicación.

En la antropología, el turismo ha sido estudiado como un sistema o un conjunto de subsistemas, perspectiva que excede a una simple consideración del turismo como un proceso o fenómeno. La ventaja de esta aproximación es que "el turismo no es visto automáticamente aislado de los ambientes políticos, naturales, económicos o sociales" (Burns, 1999: 29), y permite explorar cómo están conectados el lugar de partida y el de destino y cómo se interconectan varios sistemas o subsistemas, tales como, las políticas del país de destino y del país de origen de los turistas, la situación política económica mundial, los medios de transporte, los mercados, los suministradores de servicios, los medios de comunicación, los actores sociales de la sociedad anfitriona, etc. Además, esta perspectiva permite explorar el proceso de turismo al analizar cómo opera el sistema.

Pero no debemos de entender al turismo como un sistema solamente a partir de la lógica de trabajo, como se define el turismo como negocio, aunque el turismo está muy relacionado con las actividades económicas y el consumo. Cabe destacar que el turismo es una actividad de "ocio" que presupone su opuesto, es

${ }^{35}$ Brah (1996: 208, 209). Traducción propia al español del texto original en inglés 
decir, el trabajo regulado y organizado, y que el tiempo y el espacio en el turismo se construyen por la oposición a la lógica del trabajo. Lo que consumen los turistas, en cierto sentido, no es necesario para la supervivencia humana. Lo que se consume en el turismo son las experiencias diferentes de la vida cotidiana en el lugar de residencia y de trabajo. En el tiempo de ocio, los turistas se mueven de sus lugares de residencia, cuya cotidianeidad está estructurada por la lógica del trabajo, hacia los destinos turísticos, donde pueden experimentar y consumir una cotidianeidad efímera que está estructurada por la lógica del no trabajo, lo que subvierte el orden y el rol social que asumen en sus lugares de residencia (Grabern, 1977; Hiernaux, 2000; Urry, 1990).

Si se retoma esta característica del tiempo y espacio en el turismo, se puede definir al turismo del siguiente modo: un sistema o un conjunto de subsistemas que les hace posible a los sujetos realizar en el tiempo de ocio el desplazamiento hacia los sitios, que están fuera de los lugares normales de residencia y de trabajo, y la estancia para experimentar y consumir diferencias y contrastes con su vida cotidiana. Para que los turistas experimenten y consuman el tiempo y el espacio diferente de su vida cotidiana en el lugar de trabajo y de residencia, aparte de hacer posible el viaje y la estancia, el sistema utiliza y crea los aparatos, las instituciones sociales y las representaciones culturales que crean, producen y reproducen las diferencias y contrastes a la vida cotidiana en sus lugares de residencia. Por lo tanto, la tarea de los estudios del turismo también es la de investigar los impactos económicos, sociales y culturales en las sociedades anfitrionas como consecuencia de la operación de este sistema.

La primera implicación importante entre varias perspectivas analíticas en los estudios antropológicos del turismo es construir a los turistas y a los habitantes de las sociedades anfitrionas como sujetos de estudio para explorar los procesos socioculturales desde la construcción del tiempo, el espacio y la imagen del destino de viaje para los turistas hasta el impacto sociocultural del turismo en las sociedades anfitrionas (Smith, 1977; Robertson, 1991). La gran ventaja de esta perspectiva que se enfoca en los turistas y los anfitriones es poder explorar de qué 
modo interactúan la gente-en-movimiento y los nativos dentro del sistema o un conjunto de subsistemas en el contexto translocal.

La segunda implicación importante es que el lugar turístico no sólo es una zona de contacto entre dos poblaciones diferentes, sino una zona de contacto entre diferentes prácticas espaciales y temporales. Para los turistas, el destino del viaje turístico es el lugar donde experimentan tiempo y espacio diferentes de su cotidianeidad en el lugar de residencia y de trabajo. Pero para los habitantes de la sociedad anfitriona, el mismo lugar es el espacio donde experimentan su cotidianeidad. Por ejemplo, en el caso de una zona turística, cuya mayor atracción es la celebración de un ritual, este lugar religioso es un espacio en donde coexisten las prácticas espaciales y temporales de los turistas, las prácticas del sector comercial que está sujeto a la lógica del trabajo y ocupa la escena del evento como lugar de trabajo y las prácticas religiosas de los habitantes locales que ocupan el mismo espacio como sitio sagrado para estar separado del tiempo secular.

La tercera implicación de los estudios de turismo que quiero retomar es que la imagen del lugar de visita que describen los turistas, el sentimiento hacia el destino y el deseo de viajar no sólo se forman a partir sus propias experiencias e imaginación, sino que se construyen, antes de viajar, por las intervenciones de varios actores que se insertan en el conjunto del subsistema que forma parte del turismo, (como, los medios de comunicación, la industria de turismo y el gobierno de la sociedad anfitriona) ( Augé, 1998 y 1998a; Boorstin, 1964; Hirai, 2002).

La cuarta implicación es que varios trabajos demuestran que en el turismo el lugar, la cultura y las tradiciones no son algo preconstruidos, sino que se inventan, fabrican, modifican, e incluso se consumen (Hobsbawm y Ranger, 1983; Urry, 1995; Yamashita, 1996; Wai-teng, 1989 ). El paisaje del lugar de visita se remodela, y algunas tradiciones se modifican de tal forma que la cultura de ese lugar represente las imágenes que los turistas quieren "reconfirmar". Aquí, la cultura se "cosifica", manipula, modifica y consume como mercancía.

La quinta es que hay distintas respuestas por parte de los habitantes de las sociedades anfitrionas a las imágenes del lugar y la reconstrucción del lugar y la 
cultura local basada en las imágenes dominantes que se producen de forma masiva bajo el influjo del turismo. Quizá esta variedad de respuestas locales a los procesos translocales se entiendan mejor analizados desde la perspectiva de la "transculturación": En algunos casos, el sector mayoritario de la sociedad anfitriona se apropia de las imágenes dominantes y las tradiciones construidas para el turismo como "propias"; en otros casos, el turismo se considera como "destrucción cultural" (Greenwood, 1977), y los nativos de los lugares turísticos resisten a las imágenes dominantes del lugar en el turismo (Stewart, 1988), y a veces, la resistencia de los locales se organiza, sin salir del contexto del turismo, a través de la producción de otras imágenes (Ota, 1993; Robertson, 1991). ${ }^{36}$

La última implicación destacable es que en el turismo hay una relación importante entre las conexiones translocales y la producción y consumo de la diferencia cultural. Para la circulación de gente, dinero, objetos, información y símbolos en el turismo, es fundamental la existencia de las interconexiones entre los sitios, sobre todo entre los lugares de partida y los destinos. Como he mencionado, lo que se consume en el turismo son experiencias diferentes de la vida cotidiana en el lugar de residencia y de trabajo. Lo interesante es que la diferencia cultural y el deseo de consumir la diferencia se producen, difunden, promueven y consumen como mercancía a través de las conexiones históricas, sociales, políticas y económicas entre las sociedades anfitrionas y las sociedades emisoras de turistas.

\section{6) Estudios antropológicos sobre los sentimientos}

En los estudios de migraciones transnacionales han sido objetos principales de estudio las redes de relaciones sociales, los flujos de personas, objetos, dinero y símbolos, las organizaciones políticas, las prácticas económicas, las instituciones y otras acciones de los migrantes, las cuales han sido vistos por los investigadores como actividades y elementos fundamentales para analizar el

${ }^{36}$ En mi tesis de Maestría con el título de Viajes nostálgicos al terruño imaginario: la reconstrucción del lugar y la cultura local a través de las contiendas de imagen en la comunidad transnacional, hice una revisión de varios casos de las respuestas locales en el turismo. Véase Hirai (2002). 
vínculo entre el país receptor y el país de origen de los migrantes y para plantear nuevos modelos de espacio transnacional. Sin embargo, como lo señala Besserer (1999; 2004), los trabajos que se enfocan solamente en estos objetos de estudio que se pueden observar de manera objetiva han marginado el punto vista privilegiado de aquellos sujetos que viven sus vidas desde la transnacionalidad. Por lo tanto, cómo describir los procesos transnacionales en forma "émica", es decir, desde el punto de vista de quienes viven dentro de la sociedad estudiada, ha sido una de las tareas importantes para estos estudios. Entonces, ¿qué tipo de aproximación analítica podemos usar para hacer una ruptura con la epistemología tradicional basada en el objetivismo?

Lo que quiero presentar aquí es la aproximación que se enfoca en los sentimientos. El enfoque en los sentimientos es un punto de partida sugerente tanto para la antropología como para los estudios de migraciones transnacionales. En los años ochenta, la década en que se discutieron intensamente cómo hacer etnografías experimentales, algunos antropólogos señalaron que las etnografías clásicas se basaban en el objetivismo que se caracteriza por lo siguiente: la ausencia de la descripción del contexto social, político y histórico del campo en que se sitúa tanto el investigador como la población estudiada para realizar el trabajo de campo; el análisis y la descripción de culturas desde una mirada global para poder encontrar un sistema o un patrón; la idea de que la cultura y la sociedad son los que determinan la personalidad y la decisión de individuos, y la descripción de culturas y sociedades como entidades ordenadas, estables, invariables y perdurables (Marcus y Fischer, 1986; Rosaldo, 1989). Este modo clásico de descripción etnográfica ha sido criticado por haber excluido del marco de la etnografía y del análisis el punto de vista interno de la sociedad estudiada, relaciones de poder y económicas y cambios históricos para extraer un sistema o un patrón. El enfoque en los sentimientos es uno de los cortes del análisis social y cultural que Marcus y Fischer (1986) y Rosaldo (1989) proponen, retomando estas limitaciones de las etnografías clásicas, para entender con profundidad la particularidad cultural a partir de las versiones internas de la sociedad estudiada. 
El crítico literario marxista Raymondo Williams es quien ha dado una aportación importante a los estudios antropológicos de los sentimientos. Williams (1977) señala que hay dos tendencias dominantes en el análisis y la descripción objetivista sobre la cultura y la sociedad: la primera es que la cultura y la sociedad no se entienden ni se describen como lo que está en proceso de formación en el presente, sino como lo que ya se formó, por lo tanto, como productos que pertenecen al pasado; la segunda tendencia es que el pensamiento, la ideología, la visión del mundo y la creencia se entienden y se describen como lo "social" y como lo que ya se formó y se opone a la conciencia, la experiencia y los sentimientos, es decir, aquellos elementos "personales", flexibles y vividos en el presente que escapan de lo fijo y lo establecido.

Lo que propone Williams para salir de estas tendencias del análisis social y cultural que no permiten entender la articulación entre lo social y lo personal y analizar y describir el proceso de formación social y cultural, es el concepto de "estructura de sentimiento". La estructura de sentimiento no es algo fijo que ya se estableció con cierta forma explícita, sino que es un proceso social que los individuos viven y sienten en el presente. En este sentido es diferente de la "visión del mundo" y la "ideología" porque éstas ya están estructuradas en la vida social, por lo tanto, se pueden definir, clasificar y racionalizar. No se trata de significados y valores que ya están estructurados sistemáticamente como una cultura, sino de significados y valores que se viven y se sienten de manera activa. En lo que se enfoca este concepto de "estructura de sentimiento", es la tensión entre lo personal y lo social y entre lo que ya se formó en el pasado y lo que se vive en el presente. Es la fase justo antes de que aparezca alguna estructura formada, es decir, la fase intermedia del proceso en que las conciencias, los sentimientos, las experiencias, personalidades se convierten en una nueva estructura social. Por lo tanto, en la estructura de sentimiento, los sentimientos no son elementos opuestos a y separables del pensamiento. Aquí, el pensamiento se siente y los sentimientos se piensan. La virtud de este concepto es que en primer lugar, permite entender el punto de vista del sujeto de estudio que vive dentro de cierta situación social; en segundo lugar, el enfoque en la articulación entre lo social y lo personal permite 
explicar cómo se relacionan los sentimientos con el entorno social que rodea al sujeto y cómo diversas fuerzas sociales, políticas y económicas penetran al aspecto interior del sujeto y se inscriben en el lenguaje, los sentimientos y la imaginación, y por último, este concepto permite analizar y describir el proceso de formación cultural y social.

En su trabajo sobre las mujeres migrantes mixtecas que viven en los procesos transnacionales entre sus comunidades de origen en Oaxaca y sus lugares de destino en Estados Unidos, Besserer (2000) describe la comunidad transnacional, no como una entidad social formada, establecida y armónica, sino como un espacio social que está en proceso a través de las contiendas entre las personas que viven dentro de la sociedad estudiada. Besserer hace evidente este aspecto a través del enfoque en el cambio en los sentimientos de las mujeres que jugó un papel importante en la transformación de la realidad social. En el caso estudiado, estas mujeres migrantes indígenas han estado tradicionalmente en una situación de desigualdad de género y social sostenida por un "orden sentimental" a través del cual se ejerce el poder estatal, así como el familiar. Los sentimientos en los que se enfoca este trabajo son el "amor romántico", el "respeto" hacia las mujeres y el "enojo" hacia la violencia institucionalizada. Estos sentimientos son apropiados por las mujeres, pero son calificados como inapropiados en el orden sentimental ligado a la perspectiva masculina. En los casos estudiados, ellas movilizaron estos sentimientos "(in)apropiados" tanto en su comunidad de origen en Oaxaca como en su lugar de destino en California para subvertir los regímenes sentimentales que mantienen las desigualdades sociales y construir nuevos órdenes de sentimientos que pueden ser la base de una nueva ciudadanía transnacional.

Lo que podemos aprender de estos trabajos sobre los sentimientos es que son los siguientes puntos: en primer lugar, la aproximación que se enfoca en los sentimientos permite entender el punto de vista de las personas que viven dentro de cierta situación social estudiada, de ahí podemos lograr la descripción etnográfica de la sociedad y la cultura; en segundo lugar, permite analizar la sociedad y la cultura como "procesos", no como entidades establecidos, 
invariables y perdurables; en tercer lugar, facilita explorar de qué manera los factores y las fuerzas sociales, económicos y políticos que rodean a la población estudiada influyen en la construcción de subjetividades, y por último, esta aproximación revela cómo estas subjetividades operan y transforman la realidad social.

En resumen, los conceptos y las aproximaciones que presenté en este apartado, me permiten complejizar el análisis que ha hecho el transnacionalismo para reconceptualizar los espacios que se construyen a través de los procesos transnacionales en torno a la migración. Esto lo haré de la siguiente manera: a) En primer lugar, como propone Pratt (1992), entenderé los lugares, regiones y espacios interconectados con otros como "zona de contacto," asumiendo que ahí se da un "encuentro pos-colonial" entre los sujetos móviles y la población inmóvil bajo relaciones de poder asimétricas. b) Por lo tanto, y en segundo lugar, propongo que estos espacios están lejos de ser armónicos y estar libres de conflictos. Los entiendo como "zonas fronterizas" con conflictos, contradicciones y paradojas (Alvarez, 1995). c) En tercer lugar, a través del encuentro entre diferentes poblaciones, surgen nuevas prácticas culturales y representaciones de identidad de parte de los sujetos que se encuentran en las posiciones subalternas dentro de las redes de fuerzas económicas y políticas. Si reconceptualizamos el lugar habitado por la población inmóvil en términos de conexiones y contactos, podemos abrir la posibilidad de ver a los "nativos" como sujetos que participan en procesos transnacionales y sujetos creactivos que construyen prácticas culturales e identidades transculturales igual que los sujetos que realizan el viaje en el sentido literal. d) En cuarto lugar, no sólo se encuentran distintas poblaciones en la "zona de contacto," sino que en esta zona se experimentan diferentes prácticas espaciales y temporales, así como diferentes intereses. En este encuentro, las subjetividades de los viajeros, las tradiciones y el paisaje del lugar de destino son manipulados para realizar los intereses económicos, políticos, sociales y culturales de varios actores. A través de estos encuentros y entreveros de varias miradas, surgen las prácticas y representaciones culturales de los habitantes locales que se 
pueden analizar mejor en términos del concepto de transculturación. Me interesa destacar especialmente que a pesar de que existen las conexiones translocales y transnacionales entre las sociedades emisoras y los destinos de viaje, la diferencia cultural entre dichos extremos de la migración no desaparece. Más bien, la construcción de las imágenes, de las subjetividades de los viajeros y del paisaje dentro de las conexiones translocales se basa en la construcción de las diferencias. Además, las distintas respuestas locales al proceso translocal se agregan al repertorio de la variedad de representación cultural y definición de la imagen del lugar. Entrar en los procesos de la transnacionalización de la vida y tener conexiones con otros lugares dentro de un contexto más amplio significa estar entreverado en una nueva y compleja configuración de relaciones de poder. En este sentido, vivir en un lugar con conexiones transnacionales significa entrar en un punto de convergencia de muchas fuerzas. Pero, como sostiene Foucault (1982:220), "estar entreverado en una malla de relaciones de poder abre la posibilidad de nuevas formas de resistencia y creación". f) Por último, para entender cómo penetran estas fuerzas en la vida interior de los sujetos situados en una malla de relaciones de poder, cómo múltiples miradas coexisten, se entrecruzan y chocan dentro los espacios construidos por las conexiones transnacionales y qué papel juegan las subjetividades de aquellos que viven en los procesos transnacionales en la transformación de espacios, culturas e identidades, hago énfasis en iniciar el análisis desde el entendimiento del punto de vista de distintos sujetos que viven dentro de los procesos transnacionales.

\section{METODOLOGÍA Ó ¡SIGUE LA IMAGEN!}

¿De qué manera podemos diseñar una investigación antropológica que intente describir etnográficamente las conexiones transnacionales entre varias localidades? ¿Cómo podemos incluir a los sujetos de estudio con distintas experiencias en el proceso de transnacionalización en la investigación para explorar las relaciones entre ellos en el proceso de reconstrucción del lugar y la cultura local? ¿Qué tipo de trabajo de campo nos permite captar la realidad en 
otros sitios que están distantes? ¿De qué modo podemos estudiar el vínculo entre las subjetividades, el lugar y la cultura en un terreno transnacional?

En este apartado, tomando en cuenta las discusiones anteriores, propondré una metodología, que denomino seguir la imagen del terruño, con la cual se analizan los datos etnográficos en los siguientes capítulos.

Esta metodología tiene tres facetas para el análisis. En la primera faceta, se selecciona un objeto de estudio estratégico y se enfoca el análisis en la circulación de este objeto de estudio con el fin de delinear los espacios de vida de las poblaciones estudiadas. Marcus (1998) propone la estrategia de seguir (en el sentido literal), a un sujeto de estudio o un objeto de estudio, moviéndose entre múltiples sitios para describir cómo los espacios sociales de los sujetos de estudio se constituyen de las conexiones entre varios sitios. El objeto de estudio que el investigador debe de seguir varía dependiendo del tema de investigación. En mi caso, escogí la imagen del terruño de los migrantes, dado que una de las particularidades del caso etnográfico estudiado aquí es la ubicuidad de la imagen del lugar de origen de los migrantes mexicanos en distintos lugares y que es un objeto de estudio estratégico para analizar distintas formas de percibir y representar el terruño entre los migrantes, sus familias y los habitantes del lugar de origen.

La segunda faceta para el análisis se concentra en explorar el proceso de producción y consumo de la imagen del terruño. Esto requiere una mirada analítica que recorre varios lugares no sólo en el sentido de recorrer los lugares como espacios físicos con el fin de captar el proceso concreto de producción y consumo de la imagen en cada sitio, sino también de explorar la relación entre tres prácticas espaciales diferentes sobre el terruño (hometown o homeland): el terruño imaginario, el terruño simbólico y el terruño como espacio físico. El terruño imaginario es el lugar que la gente describe en su mente, es decir, la imagen mental del lugar de origen. El terruño simbólico es el lugar de origen representado en las imágenes materiales, narraciones y discursos. Las experiencias de otras personas en el lugar de origen y el terruño imaginario que otro describe no se pueden observar ni transmitir hasta que se representen. Por eso, las imágenes 
que voy a seguir son estos símbolos del lugar de origen. Por su parte, el terruño como espacio físico es espacio donde los individuos realizan sus prácticas materiales.

Harvey (2004) explica de una manera similar pero con más detalle estas tres diferentes prácticas de espacio, resumiendo la idea de tres dimensiones que Lefebvre (1974) definió como lo experimentado, lo percibido y lo imaginado. La primera práctica espacial que plantea Harvey es "practica material espacial". Esto corresponde a lo que denomina Lefebvre como "lo experimentado", yo, como el "terruño como espacio físico". Para Harvey, estas prácticas espaciales "designan los flujos, transferencias e interacciones físicas y materiales que ocurren en y cruzando el espacio para asegurar la producción y la reproducción social." La segunda práctica espacial incluye las "representaciones del espacio" que abarcan todos los signos y significaciones, códigos y saberes que permiten que esas prácticas materiales se comenten y se comprendan, sea con las nociones del sentido común cotidiano sea con la jerga, a veces enigmática, de las disciplinas académicas que se vinculan a las prácticas espaciales (la ingeniería, la arquitectura, la geografía, la planificación, la ecología social, etcétera)." Lefebvre denomina esta dimensión como "lo percibido". Esto corresponde al "terruño simbólico" que se caracteriza en mi esquema. La tercera práctica espacial son los "espacios de representación" (o imaginación) que corresponde a "lo imaginado" de Lefebvre y el "terruño imaginario" a lo que me refiero. Son "invenciones mentales (códigos, signos, "discursos espaciales", proyectos utópicos, paisajes imaginarios y hasta construcciones materiales, como espacios simbólicos, ambientes construidos específicos, cuadros, museos, etc.) que imaginan nuevos sentidos 0 nuevas posibilidades de las prácticas espaciales." (Harvey, 2004: 244).

En cuanto a las relaciones dialécticas entre estas prácticas espaciales, Harvey señala que "los espacios de representación no sólo tienen la capacidad de afectar la representación del espacio, sino también la de actuar como una fuerza de producción material con respecto a las prácticas espaciales" (245). En otras palabras, el imaginario no sólo influye en lo simbólico, sino también en la realidad 
que existe en el espacio físico. ${ }^{37} \mathrm{El}$ proceso en que el terruño imaginario opera sobre la realidad del terruño como espacio físico a través de la intervención de los símbolos en la formación del primero se puede entender con el término de "terruño imaginado".

Benedict Anderson (1983) fue quien descubrió de qué modo las imágenes como símbolos operan sobre la imaginación y la capacidad de percibir la realidad del espacio físico y sobre el proceso de construcción del estado-nación como una comunidad nacional imaginada. La difusión del idioma nacional impreso en periódicos y literaturas ha facilitado crear los vínculos "imaginados" entre los individuos que en realidad no tienen ninguna interacción social por la distancia. Por consecuencia, los individuos sienten pertenencia a la misma comunidad nacional imaginada. Por lo general, la comunidad se plantea como un espacio donde todos los miembros se conocen cara a cara, pero al decir la comunidad "imaginada", Anderson señala el aspecto artificial y contradictorio del nacionalismo moderno. El estado-nación moderno se plantea como una comunidad donde todos comparten el idioma, las costumbres y los modos de vida, la identidad, pero en realidad no se conocen cara a cara. Esta comunidad no es una entidad política y social que ya existe, más bien es algo que se describió como imagen en la mente, pero este imaginario colectivo dominante se confunde con la realidad social y tiene la fuerza de ejercer una influencia material sobre el espacio físico y la realidad.

Las discusiones que hacen Baudrillard (1978) y Eco (1999) sobre los conceptos de "simulacro" e "hiperrealidad" explican cómo el imaginario y los símbolos operan sobre la realidad del espacio físico, particularmente, cómo el lugar imaginario se materializa en el espacio físico en el proceso de producción masiva y consumo de las imágenes. Según Baudrillard, hoy en día, en ocasiones, los simulacros preceden a la realidad e "intentan hacer lo real, todo lo real, con sus modelos de simulación" (Baudrillard, op.cit:: 10). Por lo general, pensamos que la ficción es un simulacro de la realidad y que la realidad precede a la ficción. Pero,

${ }^{37}$ Para consultar la definición de lo imaginario y la relación entre lo simbólico y lo imaginario, véase Abilio Vergara Figueroa, 2001, "Horizontes del imaginario. Hacia un reencuentro con sus tradiciones investigativas", en Imaginarios: horizontes plurales, Abilio Vergara Figueroa (ed.), México, D.F., Escuela Nacional de Antropología e Historia, pp. 11-83. 
en este orden de los simulacros, es al revés: la realidad nace de la ficción e imita a la ficción. La realidad construida de este modo es una "hiperrealidad" (Eco, 1999). ${ }^{38}$

Uno de los casos extremos de este orden de los simulacros es Disneylandia (California). La animación Disney, primero, nació de la imaginación de Walt Disney. Su mundo imaginario y de fantasía se les transmite a millones de personas a través de la pantalla de la televisión, del cine, libros y juguetes. Este lugar de diversión se construyó para materializar el mundo imaginario de Walt Disney y el de millones de consumidores de su fantasía. Es un lugar más "verdadero" y "real" que el primario (la animación o el imaginario de Walt Disney) aunque este lugar es real y existente pero nacido de la ficción, no de la realidad, dado que ahí, el mundo Disney, que está en el espacio de la segunda dimensión originalmente, está en nuestro mundo y se ha construido no con animales antropomorfizados, sino con seres humanos (Eco 1999). En pocas palabras, la hiperrealidad anula los límites entre la ficción y la realidad. Es una realidad construida a partir del simulacro para venderla como mercancía. Pero "no se trata de imitación ni de reiteración, incluso ni de parodia, sino una suplantación de lo real por los signos de lo real (Baudrillard, 1978: 11). Es más verosímil que lo primario y lo real: es lo hiperreal.

Tomando en cuenta estas discusiones para las relaciones entre el lugar imaginario, el simbólico y el espacio físico, se puede plantear este esquema de las relaciones triangulares entre el terruño imaginario, el terruño simbólico y el terruño como espacio físico como lo muestra en la figura 1 de la siguiente página.

\footnotetext{
${ }^{38}$ Véase el capítulo titulado "Viaje a la Hiperrealidad" del libro de Eco (1999).
} 


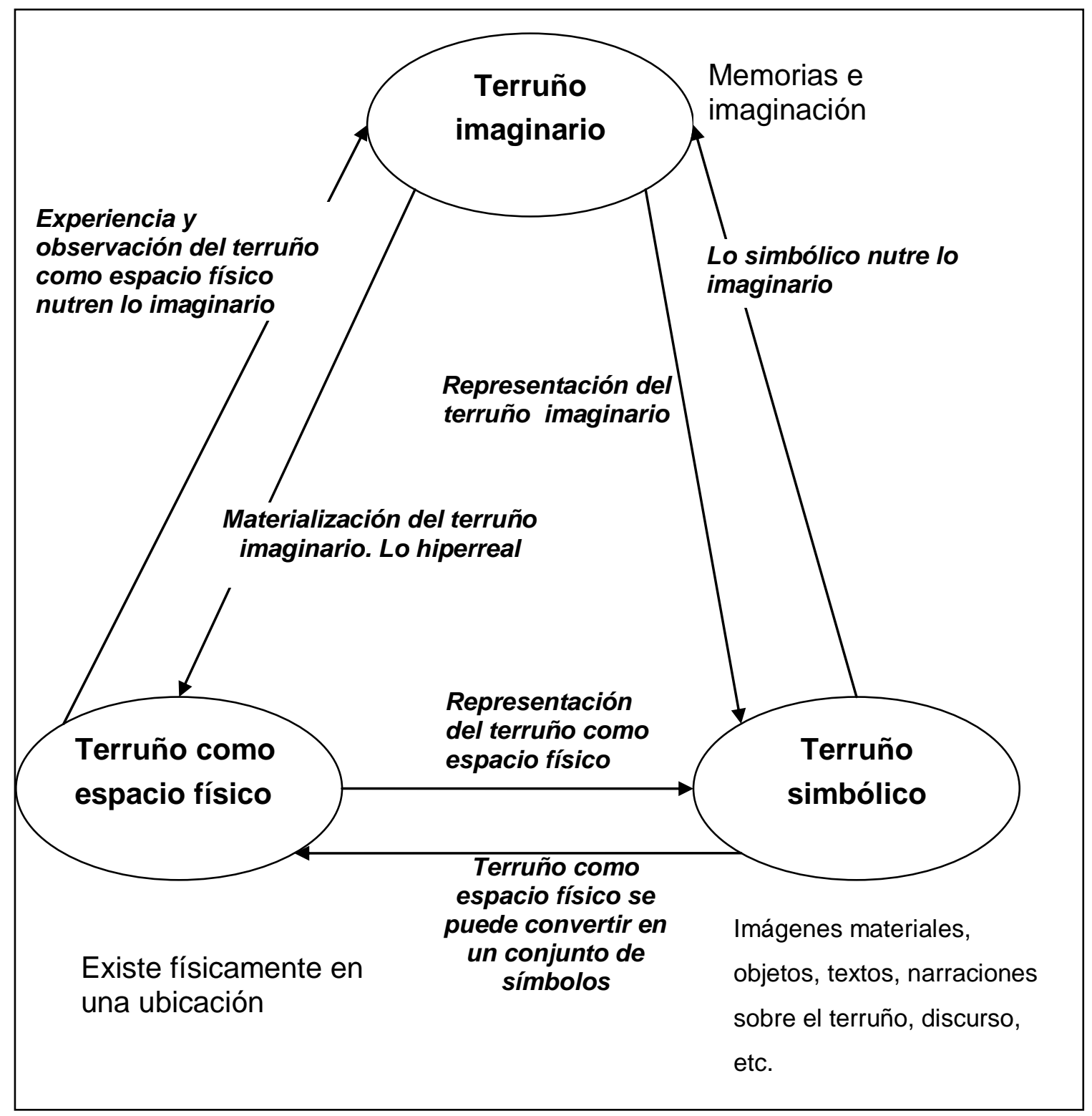

Figura 1 Relaciones entre el terruño imaginario, el terruño simbólico y el terruño como espacio físico.

El terruño imaginario es la imagen mental del lugar de origen construida a partir de memorias e imaginación. Como señalan los escritores diaspóricos, los sujetos desplazados que viven como minorías en la tierra extranjera sufren un sentido de pérdida del hogar y del pasado (Morrison, 1990; Rushdie, 1991). La nostalgia es el deseo de llenar estos huecos en su mundo interior y restaurar estos elementos perdidos. Lo que hacen para recuperar su pasado y su hogar es reconstruirlos en sus memorias. Pero, las memorias no están completas para 
restituir de manera precisa lo que se perdió. Para completar estas memorias, ellos utilizan la imaginación. Por eso, el lugar que se reconstruye de este modo es una ficción o un terruño imaginario (imaginary homeland) (Rushdie, 1991).

El terruño imaginario no puede ser transmitido por sí mismo. Tiene que pasar al nivel de representación para ser visible y transmitido. El terruño simbólico se refiere a la representación del terruño imaginario. Existen varias formas de representar el imaginario: las imágenes materiales, objetos, textos, narraciones, discursos, etc. En este sentido, para entender los terruños imaginarios que los individuos construyen en su memoria e imaginación con el sentimiento de nostalgia es necesario analizar estos terruños simbólicos.

Pero, las representaciones pueden influir en la construcción del terruño imaginario. Las imágenes pueden influir en la capacidad de las personas de percibir la realidad y el lugar (Boorstin, 1964; Augé, 1998 y 1998a). Por ejemplo, Paula Ebron (2000), analizando el caso de la construcción de la imagen de "madre África" para la diáspora afro-americana en Estados Unidos a través de la intervención de los medios de comunicación, la industria de turismo y las publicidades comerciales, revela cómo las imágenes materiales producidas sobre África juegan un papel importante en el auge del viaje a África entre los afroamericanos, nutriendo su deseo de viajar a esta tierra mítica. En el caso estudiado por Ebron, la nostalgia se utiliza como un eslogan publicitario para realizar intereses económicos del sector comercial que pretende aproximarse a los consumidores afro-americanos. En este sentido, "África" representada en los productos y las publicidades es un tropo para operar sobre las subjetividades de los consumidores y sobre el origen imaginario de la diáspora negra de ese país.

El terruño como espacio físico se refiere al terruño de los migrantes que existe físicamente en una ubicación geográfica. Las experiencias y las observaciones de este espacio físico nutren las memorias e imaginación sobre ese lugar. Las experiencias que tuvieron los individuos en ese lugar en el pasado se recuerdan y se imaginan como los elementos que contrastan con su vida cotidiana del presente en el lugar espacio-temporalmente remoto al sentir la nostalgia. De este modo, influyen en la construcción del terruño imaginario. Asimismo, el terruño 
como espacio físico pasa al nivel de representación y simbolización, se describe, se filma y graba y se representa de varios modos. Estos símbolos no sólo reflejan los sentimientos hacia ese lugar de aquellas personas que fabrican estos terruños representados, sino que también, como expliqué anteriormente, nutren las memorias, la imaginación y los sentimientos de otras personas sobre ese lugar.

No obstante, la más notable de las relaciones entre estos tres niveles del "terruño" es cuando se materializa lo imaginario en el lugar que existe físicamente. En este proceso, el terruño como espacio físico pasa por diferentes niveles de representación, y se convierte en el "terruño imaginado", es decir, un conjunto de símbolos y discursos aterrizados e incrustados en el lugar que controlan en forma organizada las memorias, la imaginación y los sentimientos de los individuos sobre ese lugar, construyen un imaginario colectivo dominante y les hacen confundir a los individuos la ficción y el imaginario con la realidad. Este terruño es más verosímil y real que el terruño imaginario y el terruño simbólico porque está hecho del paisaje, edificio, tradiciones, gente y objetos que materialmente existen y pueden percibirse físicamente, y por lo tanto, es un lugar que les permite satisfacer su nostalgia y realizar su sueño de retorno de una manera hiperreal.

Cabe señalar que pueden existir una gran variedad de terruños imaginarios, distintos modos de representar e interpretar las imágenes, pero que el acceso a la representación del imaginario y a la materialización del imaginario en las escenas físicas de representación no está abierto para todos los individuos. Como lo señala Stewart (1988), existen diferentes formas de sentir la nostalgia hacia el mismo lugar entre los sujetos que viven en ese lugar como viajeros y como lugareños. En la tercera faceta para el análisis de la metodología de "seguir la imagen", me detendré en analizar diferentes posicionamientos de los sujetos dentro de las redes de fuerzas económicas y políticas que envuelven a múltiples localidades que forman parte del espacio de vida construida por las conexiones transnacionales, para revelar las relaciones de poder que están detrás del proceso de producción y el consumo de imágenes del terruño.

La nostalgia es el deseo de regresar al hogar y el terruño. Pero de cierta manera, la materialización del terruño imaginario en el lugar de origen de los 
migrantes es una manera de cumplir el sueño del retorno y el deseo de tener contacto real con el terruño que imaginaba el migrante. Pero, cuando el lugar imaginario del sector dominante de la sociedad que se materializa conforme a su "nostalgia hegemónica" en el lugar que existe físicamente, no coincide con el imaginario de otros sectores de la población y lo excluye de la escena de representación, el cambio cultural que intenta crear la hiperrealidad para los grupos dominantes puede despertar en otros la "nostalgia subalterna y de resistencia" hacia el mismo lugar (Stewart, 1988). Las tensiones sociales, contiendas y negociaciones que se dan en torno a esta contienda entre diferentes nostalgias se analizan en esta faceta. De este modo, se examinarán las relaciones entre dos sujetos de estudio, es decir, los migrantes y la población no migrante.

En suma, con esta metodología de seguir la imagen del terruño no propongo un simple análisis simbólico de las imágenes. Más bien, al recorrer distintos sitios de producción y consumo de las imágenes, diferentes formas de representar el terruño y tres diferentes niveles del terruño, lo que intento revelar son las relaciones entre los sujetos móviles y los "nativos" del lugar, las relaciones complejas económicas, políticas, sociales y culturales en las que están entreveradas múltiples localidades y ambos sujetos y el proceso de reconstrucción del lugar y la cultura local en el contexto transnacional. En este sentido, esta aproximación parte de una suerte de "fetichismo metodológico", por el cual Appadurai (1991a) investiga las relaciones sociales que subyacen al "objeto" estudiado. ${ }^{39}$

${ }^{39}$ Appadurai (1991b) sostiene que el valor está en las mercancías, pero, lo que representan las mercancías se crea por el intercambio. Con el término de "fetichismo metodológico", no sólo propone enfocarse en los símbolos y el valor que las mercancías representan, sino seguir las cosas-en-movimiento para revelar su contexto social y político. En otras palabras, "las mercancías, como las personas, tienen una vida social" (Appadurai, 1991b:17). Sin embargo, como señala Chow (1993), Appadurai personifica las mercancías, pero, no incluye a las personas en la categoría de las mercancías. La fuerza de la comercialización en el capitalismo no hace distinción entre personas y mercancías. En el caso de la migración, las personas son mercancías que se venden y se compran. También son mercancías los "nativos" como "especímenes exóticos o étnicos" en el turismo (véanse Bruner, Edward, "Of Cannibals, Tourists, and Ethnographers", en Cultural Anthropology, 1989, 4(4), pp. 438-445, y Nancy Christine Lutkehaus (1989), "'EXCUSE ME, EVERYTHING IS NOT ALL RIGHT': On Ethnography, Film, and Representation", en Cultural Anthropology, 4(4), pp. 422437. 
La etnografía multilocal podría dar la impresión de correr el riesgo de perder la profundidad del análisis etnográfico en comparación con el clásico método antropológico de estar en una sola localidad durante un largo plazo. No obstante, en el contexto en que la economía, las relaciones sociales, la política y la cultura de una localidad están construidas a través de las conexiones entre localidades, realizar el trabajo de campo localizado en una sola localidad ya no es suficiente para tener profundidad de análisis. Tampoco es suficiente describir simplemente las conexiones y circuitos transnacionales o delinear los espacios, siguiendo un objeto de un lugar a otro, dado que el ejercicio de simplemente trazar las líneas marcadas por la circulación transnacional para plantear un nuevo concepto espacial carece del análisis de cómo lo que fluye y viaja dentro de las conexiones transnacionales afecta y se aterriza a la vida cotidiana de los habitantes de una localidad. Para evitar estos dos problemas, armé la metodología de "seguir la imagen" enfocándome en las diferentes prácticas espaciales sobre el terruño entre dos diferentes sujetos y las tensiones y el entrecruzamiento entre ellas.

En otras palabras, este trabajo no es un estudio convencional de los nativos en una localidad del tipo de la aldea aislada (real o metodológicamente). Aquí, los nativos son habitantes del lugar de múltiples convergencias y articulaciones. Tampoco intento proponer una "nomadología" (Clifford, 1999), es decir, los estudios enfocados simplemente en aquellos sujetos de estudio que viajan. Esta es una metodología alternativa a estas dos. Por eso, (siguiendo a Clifford), los sujetos de estudio en esta investigación son de dos tipos: viajeros en residencia y residentes en viaje (Clifford, 1999). 


\title{
Capítulo 2
}

Jalostotitlán ante la nostalgia y la alienación

\begin{abstract}
hemos creado una familia a la que nutrimos con nuestros valores, así religiosos como costumbristas, con el amor y la nostalgia por aquel trozo de patria, "la patria chica", que un día nos vimos precisados a dejar, si bien físicamente, jamás con el recuerdo, sublimado por el tiempo y distancia.

("Raíces", Guadalupe Gutiérrez de Mantecón, 2003, La Querencia, p.95).
\end{abstract}

\section{INTRODUCCIÓN}

Nostalgia es un término que se compone de dos palabras griegas: nostos (significa regresar a casa) y algos (significa sufrimiento). Desde la segunda mitad del siglo XVII a la segunda mitad del siglo XIX, en Europa, la nostalgia se consideraba como un desorden psiquiátrico temporal que podría causar la muerte. $^{40}$

En 1678 Johannes Hofer, un médico suizo, inventó este neologismo para referirse al dolor y sufrimiento que sentían sus pacientes por la causa de no poder estar en su tierra natal. Anteriormente este tipo de padecimiento se describía con diferentes nombres en los estudios médicos, tales como, maladie du pays en francés, Heimweh en alemán, el mal de corazón en español. Hofer usó este término para definir la categoría diagnóstica de dos pacientes que tuvieron desesperación, ansiedad, fiebre, palpitaciones, pérdida de apetito después de moverse de sus tierras natales a otros lugares. El único deseo que tenían era regresar a casa.

En el siglo XVIII en Europa, la nostalgia se aceptaba como una enfermedad mental que se observaba con frecuencia entre los soldados de servicio en el

${ }^{40}$ Edward Brown hizo una nota muy interesante de la historia de nostalgia como una categoría diagnóstica durante el siglo XVII y XIX. En esta parte del origen de la palabra nostalgia, resumí brevemente sus descripciones históricas basadas en la revisión de varios textos acerca de la nostalgia estudiada como una patología durante aquellas épocas. Puede consultar esta nota en la siguiente página de Internet:

http://bms.brown.edu/HistoryofPsychiatry/nostalgia.html

Para consultar las concepciones históricas de nostalgia, también véase Sedikides et al. (2004: 200-202). 
extranjero. Para los países europeos que iban a participar a la guerra, la nostalgia era un problema muy serio. Muchos soldados que entraron al ejército por la conscripción de gran escala sufrían de depresión, ansiedad, indolencia, fiebres y debilitamiento. Los tratamientos médicos en el hospital no les servían y, en ocasiones, era necesario que se descargaran de su servicio militar los individuos que padecían de la nostalgia gravemente, dado que el único tratamiento que servía era regresarlos a sus hogares (Rosen, 1975: 37-40).

Entre los años veinte y los treinta del siglo XIX, aumentó el número de los estudios médicos sobre la nostalgia. Muchos médicos de esa época creían que la causa de esta enfermedad tenía que ver con las primeras conexiones afectivas de las personas con el lugar de su niñez. El apego a las memorias de su niñez era el núcleo de este desorden mental, dado que las primeras impresiones de la vida se quedaban permanentemente en el cerebro (Roth, 1991: 9).

En Estados Unidos durante la Guerra Civil, los médicos usaban el término nostalgia para referirse al síntoma que hoy se considera como desorden por estrés. Durante la Guerra Civil, se reportaron varios casos de la nostalgia de los soldados. Por ejemplo, entre 1861 y 1866 hubo miles de casos de nostalgia y docenas de muertos por la misma causa en las tropas de los soldados "blancos" en el ejército federal (Anderson y Anderson, 1984: 157).

No obstante, hasta los años setenta del siglo XIX, desapareció el interés médico en la nostalgia. La nostalgia había dejado de considerarse como una enfermedad particular. Más bien comenzó a considerarse como un síntoma o una etapa del proceso patológico y una forma de melancolía (Rosen, 1975: 43-44). Desde un principio la nostalgia nunca fue una "unidad patológica". ${ }^{41}$

Aunque haya perdido su significado patológico, la nostalgia sigue existiendo hoy en día como categoría de análisis y como vocablo de uso común. En el uso contemporáneo de la nostalgia, esta palabra, por lo general, se refiere a la "pena de verse ausente de la patria o de los deudos o amigos" o "tristeza melancólica

${ }^{41}$ Sedikides et al. (2004) señala que hasta finales del siglo XIX y principios del siglo XX, la definición de nostalgia había transitado de una enfermedad cerebral al desorden psiquiátrico. Desde entonces hasta mediados del siglo XX, la nostalgia había sido estudiada como problema de la salud emocional provocada por el desorden psiquiátrico (201). Por ejemplo, Frost (1938) definió la nostalgia como "psicosis de inmigrante". 
originada por el recuerdo de una dicha pérdida, añoranza". ${ }^{42}$ Como lo señala la traducción de este término al inglés, homesickness, la nostalgia es un estado de ánimo o un sentimiento relacionado con el hogar. Es la tristeza o el malestar a causa de la distancia de su tierra natal, y a la vez es un anhelo por su hogar y un deseo de reducir la distancia con su patria chica.

En este capítulo, revisaré distintas formas de narrativa sobre esta subjetividad que ha surgido de las experiencias del desplazamiento. Particularmente, a partir del análisis de las narrativas de los jalostotitlenses que han dejado su tierra natal desde principios del siglo XX, haré una tipología de la nostalgia (o de las nostalgias) con el fin de revisar distintos modos de distanciarse del terruño en las experiencias migratorias. Trataré de explicar cómo el sujeto desplazado se distancia de la tierra natal y la pierde de distintos modos (aparte de la separación espacial) aunque la nostalgia es básicamente un sentimiento provocado por la pérdida de hogar, por la separación física, por el desplazamiento. Asimismo, argumentaré que el objeto de la nostalgia, y la imagen de la tierra natal que añora el sujeto, varían dependiendo del modo de separación del terruño.

\section{DISTANCIA ESPACIAL}

En la plazuela de enfrente del templo parroquial de Jalostotilán, está un busto de bronce. En la base del busto está inscrito el nombre Alfredo R. Placencia, el poeta jalisciense oriundo de Jalostotitlán, cuyas obras literarias influyeron sobre los poetas y escritores de la región. Este poeta nacido en 1875, después de pasar su infancia en Jalostotitlán, se trasladó a Guadalajara para estudiar en el seminario donde tuvo formación sacerdotal y descubrió su pasión y devoción por la poesía. Al terminar sus estudios en el seminario en 1899, comenzó su carrera sacerdotal como ministro en la parroquia de Nochistlán, Zacatecas. Desde entonces hasta su muerte en 1930, se dedicó al sacerdocio y a escribir poesía, viajando de pueblo en pueblo sin permanecer por mucho tiempo en un solo lugar, en ocasiones, saliendo del país. De hecho, durante 30 años de su vida sacerdotal,

\footnotetext{
${ }^{42}$ Diccionario de la lengua española, Real Academia Española.
} 
se trasladó a más de 20 lugares, incluyendo Estados Unidos y la República de El Salvador. ${ }^{43}$

Durante 30 años de su vida en un ir y venir constante escribió 260 poemas y publicó tres libros antes de su muerte (El Libro de Dios; El paso del dolor; y Del cuartel y del claustro). ${ }^{44}$ Los sentimientos encontrados en los destinos del desplazamiento son temas principales de la mayoría de sus obras. Por ejemplo, cuando se fue voluntariamente a Estados Unidos en 1924 para prestar sus servicios a los mexicanos residentes en Los Ángeles, la lejanía de su patria le inspiró a escribir un poema titulado "Acostarse en el mar":

Hasta ayer fuiste ola pacíica de río

Y cansada de serlo te aventuraste a andar

Y rueda y rueda, a ejemplo mío,

Hasta perder la tierra para hundirte en el mar. ${ }^{45}$

En la mayoría de sus obras, lamenta la soledad, el dolor y la tristeza que experimentaba en una vida de separación de su tierra natal en los destinos y expresa la nostalgia y la añoranza hacia su terruño. En un poema dedicado a su compañero del seminario, describe la tierra natal como un "paraíso", en cambio lamenta la vida presente en su destino.

Al cumplir los doce años de edad era preciso dejar, para ser hombre, mi natal paraíso.

Y allá quedó la madre por el ausente orando, y los hijos creciendo en fraterna armonía,

${ }^{43}$ En febrero de 1903, en San Pedro Apulco, Jaslico. En abril del mismo año, en Bolaños, Jalisco. Dos meses después, en San Gaspar de los Reyes, Jalisco. En el fin de ese año en Guadalajara. En 1905, en Amatitán, Jalisco. En mayo de 1910, en Ocotlán, Jalisco. En julio del mismo año, en Temaca, Jalisco. En 1912, en Portezuelo, Jalisco. En 1913, en Jamay, Jalisco. En 1914, en El Salto, Jalisco. En 1916, en Acatic, Jalisco. En 1918, Tonalá, Jalisco. En 1920, Atoyac, Jalisco. En 1921 en San Juan de los Lagos. En noviembre de 1922, en Capilla de Guadalupe, Jalisco. En diciembre de 1922, en Guadalajara. En 1923, se fue a Los Ángeles, California, voluntariamente para presentar sus servicios a los mexicanos residentes en esa ciudad. En 1926, se fue a la República de El Salvador para escapar de la persecución religiosa. En 1930 terminó su vida errante en Guadalajara.

${ }^{44}$ Unas décadas después de su muerte, las personas que tuvieron su amistad y recibieron sus libros y manuscritos, trabajaron para que salieran a la luz el resto de sus obras. En 1946 Alfonso Gutiérrez Hermosillo publicó de la UNAM la Antología de Placencia. En 1959, Luis Vázquez Correa publicó la edición completa de su poesía.

${ }^{45}$ Ramírez (1992: 135). 
y el padre, como abeja, sin cesar trabajando;

mientras yo, con el alma temblorosa de frío,

di la espalda a mis lares, crucé el bullente río,

subí el cerro que llama allá "de la Cantera",

y parado a la postre en su más alta cumbre,

con los ojos bañados y con la faz austera

dije adiós a mi pueblo y adiós a mi techumbre, a mis padres y a todo, por si ya no volviera.

$[\ldots]$

Y así llegué a la urbe a la edad de doce años, cargado con mis cosas, como ando todavía

por esta Yanquilandia tan brumosa y tan fría,

de gentes tan severas y de usos tan extraños. ${ }^{46}$

Lo evidente en sus cantos es que la añoranza y la nostalgia no son sentimientos construidos por el desplazamiento en sí. Más bien, varias experiencias amargas en su vida errante le hicieron decepcionarse de la vida presente en el nuevo lugar de residencia, lamentar la distancia física con su tierra natal y añorar la tierra donde nació y creció. Los fracasos en la carrera sacerdotal, la inadaptabilidad al nuevo ambiente del destino, la incomprensión de la gente, su aislamiento semivoluntario, la enfermedad, la pobreza, la muerte de sus seres queridos y dos guerras que devastaron los pueblos y los campos del occidente de México y su vida (la Revolución Mexicana y la guerra cristera) eran factores que nutrieron sus descontentos con la vida en el nuevo hogar, la soledad, la angustia y la nostalgia hacia su terruño. ${ }^{47}$ Para Placencia, todos estos sentimientos y desgracias que le acompañaron en su vida errante fueron el motor y la fuente de

${ }^{46}$ Ramírez (1992: 98-99).

${ }^{47}$ En contraste con su vida como poeta, su carrera sacerdotal no fue nada brillante. No recibió honores y altos cargos ni hizo algo sobresaliente en su oficio en las parroquias. Su fracaso en el sacerdocio se refleja en sus continuos traslados. Para el arzobispado de Guadalajara, el poeta siempre fue un dolor de cabeza. Por su conducta no edificante, sus desencantos en el ejercicio del ministerio, problemas con sus superiores, compañeros y feligreses, fue mantenido lejos de Guadalajara y destinado a pueblos pequeños y alejados en Jalisco. En un poema expresa sus fracasos en su vida práctica. Además del fracaso en su carrera, la separación de sus seres queridos fue otras desgracias que le causaron la soledad pero que nutrieron y alimentaron su inspiración. En 1896, Alfredo perdió a su padre. En 1910, perdió a su madre cuando él estaba en Temaca, Jalisco, una aldea lejana de donde falleció su madre. Y luego, en la Revolución Mexicana, el hermano que fue soldado perdió su vida. Su hermana que fue monja también se había ido antes que él. La perdida de su familia y desaparición completa de su hogar le inspiraron a Alfredo escribir varios poemas. Alfredo vivió una época difícil. La Revolución Mexicana, en la cual perdió la vida su hermano, y la guerra cristera, que le obligó a escapar a la República El Salvador. 
inspiración para escribir. Más bien, escribir poesía era la única manera de obtener consuelo y la única forma para aliviar la inmensa soledad para alguien como Alfredo quien siempre padecía del dolor, la soledad y la nostalgia (Ramírez, 1992: 33). En este sentido, para él, Jalostotitlán como objeto de nostalgia y añoranza que aparece en muchas de sus obras era un lugar de consuelo de las experiencias amargas en el destino de viaje y un punto distante que le permitía escapar del dolor de la vida presente. Para él, ese punto lejano no se encontraba en algún lugar desconocido ni en un futuro lleno de oportunidades y esperanzas, sino los puntos que precedían a su vida presente en el punto del desplazamiento, es decir, el punto de partida de su viaje, su tierra natal, su hogar donde creció y su pasado.

La época en que Placencia vivió su vida errante de tres décadas era precisamente el período de inicio de migración hacia Estados Unidos en Jalostotitlán. En las primeras dos décadas del siglo veinte los primeros grupos de migrantes se fueron a Estados Unidos. Durante la investigación, no pude encontrar algún texto o historia oral que me permitieran saber las subjetividades de los migrantes que se fueron a Estados Unidos durante las primeras dos décadas del siglo XX. Pero hay un caso de nostalgia de una familia migrante que se fue a Estados Unidos en la segunda mitad de los años veinte y regresó a Jalos en 1932. En 1981, don Severiano Jáuregui Pérez, un migrante originario de Jalostotitlán, publicó en Los Ángeles un libro titulado Libro de los talentos con la colaboración de sus paisanos de Jalostotitlán radicados en California. El libro está basado en varias entrevistas que él mismo realizó en distintas localidades de Estados Unidos y México. La mayoría de los entrevistados fueron oriundos de Jalos. La entrevista con don Félix, quien se encontraba en Hacienda Heights en el momento de la entrevista, es una de tantas entrevistas transcritas en este libro. En la primera parte de la entrevista, don Félix narra el recuerdo de su primera experiencia migratoria y el motivo del retorno de su familia a Jalos en 1932.

Al transcurso de cinco años, en 1932, todos nos regresamos de nuevo a Jalos, nuestro lugar de origen. 
Fue entonces cuando aquí, en Estados Unidos, la famosa depresión había alcanzado su punto más crítico; pero no nos fuimos, quiero aclarar, no nos fuimos, por la escasez de trabajo; sino que más bien nos fuimos, por la añoranza que sufríamos por nuestro pueblo y por el resto de los parientes que se habían quedado allá [...]

El motivo principal por el que nos regresábamos era de un sentimentalismo puro; no podíamos soportar la ausencia de los seres queridos. No podíamos vivir más tiempo separados. ${ }^{48}$

Él estuvo en Estados Unidos por primera vez con su familia cuando él tenía entre 17 y 22 años de edad. El año en que su familia se fue a ese país fue 1927, dado que comenta que estuvo cinco años ahí hasta 1932. Lo interesante de este caso es el contexto social de Jalos y de Estados Unidos durante estos cinco años. El período en que su familia emigró a Estados Unidos fue cuando un gran número de familias se fueron a Guadalajara, León, Guanajuato, Aguascalientes y la Ciudad de México para escapar de la inseguridad política y social del pueblo de Jalostotitlán debido al movimiento cristero levantado en 1926. Mientras muchas familias buscaron refugios en algunas ciudades dentro del país, algunas decidieron refugiarse en Estados Unidos. En la entrevista este migrante nunca menciona el motivo del viaje de su familia a Estados Unidos. Pero es muy probable que esta familia también hubiera decidido irse de Jalos para escapar de los conflictos si se toma en cuenta el contexto social del año en que salió a Estados Unidos. Por el otro lado, el año en que la familia regresó a Jalos fue el período en que en Estados Unidos los migrantes mexicanos en general tenían que enfrentarse con la realidad severa debido a la gran depresión y la organización de la "repatriación" masiva de los migrantes. También fue el período en que Jalos estaba recuperando la tranquilidad social y política y comenzó a recibir a las familias que habían buscado refugio fuera del pueblo. El cronista jalostotitlense José Trinidad Padilla Lozano describe el retorno de los jalostotitlenses de Estados Unidos en este período de la siguiente manera: "Así las cosas, la vida en Jalos se fue normalizando poco a poco al retornar del exilio voluntario todos aquellos que por el temor y por preocupación se habían trasladado a Estados Unidos" (1988: $174,180)$. Aunque no puedo salir de la suposición, a mi juicio, la añoranza por su tierra natal, que fue motivo de la decisión de retorno a Jalos, surgió de esta

\footnotetext{
48 Jáuregui Pérez (1981: 106).
} 
circunstancia social del lugar de origen y del destino. En otras palabras, la situación inevitable de abandono de su pueblo natal, la realidad severa del destino debido a la gran depresión, el temor de la deportación masiva y la circunstancia oportuna de recuperación de la paz en Jalos podrían ser factores importantes en la formación de este sentimiento y la decisión de retorno.

En suma, lo que quiero señalar con estos dos casos de la nostalgia de los jalostotitlenses desplazados de las primeras décadas del siglo XX es que la nostalgia no es un sentimiento que nace simplemente de la separación física de la tierra natal causada por el desplazamiento espacial, sino que la angustia y la pena por la distancia espacial con la tierra natal están íntimamente relacionadas con la circunstancia y el motivo del abandono del terruño, las experiencias, sentimientos y el contexto social en el destino. Por otro lado, estos casos demuestran que la nostalgia hacia Jalostotitlán es un sentimiento histórico paralelo al comienzo del siglo del éxodo de numerosas personas originarias de este lugar.

\section{DISTANCIA TEMPORAL}

La distancia con el terruño (de la cual se lamenta el sujeto desplazado) muchas veces se puede entender en términos temporales. Por ejemplo, en la obra de Alfredo R. Placencia anteriormente citada, el poeta expresa el cariño por su tierra natal y el sentimiento negativo hacia Estados Unidos no solamente a partir de la distancia espacial, sino a partir de la distancia entre el presente y el pasado. Él no describe de forma utópica Jalostotitlán de la misma época en que él estuvo en Estados Unidos. Más bien, "mi natal paraíso" que él canta es un Jalostotitlán de su infancia donde vivió con sus padres que ya estaban muertos cuando hizo este poema en Estados Unidos.

Cuando le pregunté a un migrante de 72 años que vino de Sacramento para visitar Jalos en agosto de 2004 si sentía nostalgia hacia Jalostotitlán, me comentó que aunque había vivido en Estados Unidos durante casi 50 años, tenía puros recuerdos de Jalos, sobre todo, para él los recuerdos de su infancia cuando tenía 8 o 9 años eran más claros y relevantes. Durante la investigación, también pude observar este tipo de nostalgia hacia Jalostotitlán del pasado, particularmente, un 
Jalos de épocas anteriores cuando los migrantes internacionales y nacionales eran niños (en los años treinta, cuarenta y cincuenta). Cuando ellos expresaban la añoranza por el paisaje del campo y el estilo de vida rural de Jalos, muchas veces no se referían a la actualidad de Jalostotitlán. Más bien, el objeto de su añoranza era el rancho, donde pasaron su infancia o donde vivían sus familias antes, y Jalostotitlán como un pueblo rural muy pequeño donde todo el mundo se conocía.

En el libro titulado La Querencia escrito por una mujer originaria de Jalostotitlán, quien radicó en la Ciudad de México, se puede encontrar varios ejemplos de la forma narrativa de la nostalgia hacia Jalostotitlán en términos temporales. Guadalupe Gutiérrez de Mantecón, la autora del libro, escribió las prosas que están en el libro entre 1970 y 80 en la Ciudad de México cuando ella tenía entre 57 y 67 años de edad. En 2003, con la colaboración de sus familiares, se publicó una nueva edición del libro que originalmente se publicó en 1981 y estaba en venta en Jalostotitlán en agosto de 2003. La Sra. Guadalupe nació en 1913 y pasó su infancia en una ranchería de Jalostotitlán. Salió de Jalos en los años inmediatos al movimiento cristero, es decir, alrededor de 1926, para establecerse en la Ciudad de México. Después de su matrimonio con un español, temporalmente estuvo en la provincia de Santander, España, cuando inició la Guerra Civil (1936-1939). Cabe mencionar que la autora del libro no tuvo una formación académica estricta para ser escritora. Más bien, el libro es fruto de unos talleres de literatura e historia.

En la mayoría de las prosas del libro ella expresa la profunda añoranza por su tierra natal. Ella describe recuerdos de la familia, costumbres del hogar y del pueblo muy ligadas a la profunda religiosidad, la vida en el rancho y el paisaje del campo. Asimismo expresa la nostalgia y la añoranza por un estilo de vida tradicional de la provincia y su preocupación de que desapareciera este estilo de vida añorada y lleno de valores religiosos, por las influencias del estilo de vida moderna y urbana que llevan nuevas generaciones.

En una prosa titulada "Mi tierra", ella explica claramente cuál es el objeto de la añoranza: "No cabe preguntarme por qué amo la tierra. ¡No! No me refiero a ese conglomerado de países [...] Yo me refiero a la que fue el entorno de mis años 
primeros" (Gutiérrez de Mantecón, 2003: 94, 95). En la mayor parte del libro, ella narra recuerdos de su pueblo natal y sus padres, la añoranza por el paisaje del campo y la nostalgia hacia el estilo de vida tradicional de rancho donde pasó su infancia en los años veinte del siglo anterior cuando todavía Jalos era un pueblo pequeño y muchas de las familias vivían en el rancho como la suya.

En estas narrativas de la nostalgia de los escritores jalostotilenses y los migrantes, lo evidente es que el objeto de la nostalgia no necesariamente es un Jalostotitlán del presente, sino un Jalostotitlán del pasado. Pero estos sentimientos no se dirigen hacia recuerdos imprecisos de todo el pasado. Más bien, el sujeto añora y siente la nostalgia hacia Jalostotitlán del período en que vivió ahí, particularmente la época en que pasó el sujeto su infancia en su tierra natal. En el caso de estos dos escritores ausentes, la tierra natal que ellos describían era de su infancia, dado que salieron de ahí a una edad temprana. En este sentido, el sujeto se distanció de su tierra natal doblemente: en primer lugar, el desplazamiento separó al individuo de su tierra natal; en segundo, el tiempo lo separó de su pueblo natal donde pasó su infancia.

En esta forma de nostalgia provocada por la doble separación de la tierra natal, recordar es un acto sumamente importante para realizar el deseo de retorno. En una de la prosa titulada "Mi pueblo", Guadalupe Gutiérrez de Mantecón explica que para ella recordar es una forma para regresar a su lugar de origen y su pasado, al rancho y a su infancia y volver a ver el paisaje del campo. Cuando añoraba su tierra natal pero no podía regresar físicamente, los recuerdos le permitían realizar su retorno: "Pero cuántas veces, allá en tierras lejanas, por las noches, mis párpados velaban el desfile de imágenes queridas... El camino que va del poblado al rancho, las cercas, los recuestos, los vados propicios para cruzar el río, los viejos sabinos bordeándolo y bebiendo frescura al hundir las raíces en su orilla..." (65-66). Recordar también es una forma de hacer presentes a las personas que dejaron de existir en este mundo. En su obra titulada "Aquellos proyectos...", ella hace presente a su marido muerto a través de sus recuerdos: "Nuestra casa se fue poblando de chiquillos sanos, traviesos, pero buenos. Uno a uno, volaron para formar sus propios nidos. Él ya partió también. Pero vive aún 
aquí, en el recuerdo amable de su recitad, de su bondad profunda y constructiva [...] me parece que su presencia continúa vigilando, para que en esta casa todo marche con bien" (90). En otra obra titulada "Invitación", la autora hace presente a su marido en su mente a través de memorias para aliviar la soledad: "Estas horas lluviosas, transidas de silencio, propician tu retorno, al reclamo exigente del recuerdo [...] Hoy te llamo a gustar de mi vigilia. ¿Quieres acompañarme? ¡Estoy tan sola! Juntos recordaremos aquel pasado juvenil y fuerte, cuando tu voluntad era la mía, y mi confianza en ti, ciega y alegre" (93).

Cabe señalar que el pasado y la tierra natal que el sujeto trata de recuperar a través de sus recuerdos no representan exactamente lo que fue en el pasado ni toda la realidad que vivió el sujeto y pertenecen, de cierto modo, a la "ficción" por dos razones: una es por la característica de la narrativa de la memoria; otra es por la intervención de la imaginación.

En su libro titulado Las formas del olvido donde se explora la relación entre recuerdo y olvido, Marc Augé (1998b) explica que la memoria y el olvido se definen una con relación a la otra. "La definición de olvido como pérdida del recuerdo toma otro sentido en cuanto se percibe como un componente de la propia memoria" (20). Señala Augé: "No olvidamos todo, evidentemente. Pero tampoco lo recordamos todo. Hay algunos elementos que debe eliminarse" (23). Por ejemplo, hay que olvidar el pasado reciente para recobrar el pasado remoto. En este sentido, los recuerdos que quedan en la mente se entienden como productos de una erosión provocada por el olvido.

Si el olvido es la contraparte de la memoria a través de la cual el sujeto nostálgico trata de recuperar la tierra natal que había perdido por la separación espacial y temporal, ¿qué se le olvida para poder recordar el pueblo natal de su infancia? Augé explica tres formas del olvido que se perciben en ciertos ritos africanos. Entre estas, la forma que él denomina "la forma de olvido del retorno" es interesante. "La principal pretensión de esta forma del olvido es recuperar un pasado perdido, olvidando el presente y el pasado inmediato para restablecer una continuidad con el pasado más antiguo (66). Siguiendo la idea de Augé, la tierra 
natal y el pasado que se narran de este modo no representan toda la realidad que vivió el sujeto.

Otra razón por la cual la narración nostálgica del pasado pertenece a la "ficción" es porque el sujeto tiene que depender de la imaginación para recuperar su tierra natal desde un punto alejado temporal y espacialmente a través de las memorias. Por ejemplo, Salman Rushdie (1991), escritor nacido en Bombay, la India, radicado en Inglaterra, afirma que aquellos escritores que nacieron en un lugar pero salieron de ahí para vivir en otra parte, tales como, exiliados, emigrantes o expatriados, viven el sentido de pérdida del pasado y del hogar y están obsesionados por recuperar lo que habían perdido. No obstante, para llenar el sentido de pérdida, según él, estos escritores no intentan reconstruir las realidades objetivas. El intento de retratar las tierras natales tiempo-espacialmente distantes del presente desde las tierras extranjeras acompaña a la imposibilidad de restituir alguna realidad objetiva a través de las memorias. La alienación física de sus lugares natales no les permite restituir precisamente lo que habían perdido. El "espejo" que debería reflejar el pasado y la imagen de sus tierras natales está fragmentado de manera irrecuperable. Por eso, el pasado que se refleja en este espejo fragmentado, no es lo mismo que lo que era realmente. Las tierras natales que se recrean por memorias parciales desde la distancia temporal y espacial, son "ficciones, no ciudades o villas actuales, sino las invisibles, terruños imaginarios" (Rushdie, 1991: 10).

La intervención de la imaginación en la reconstrucción del pasado de la diáspora a través de las memorias también fue señalada por Toni Morrison en su ensayo titulado "Site of Memory" (1990). Esta escritora afro-americana reconoce que la restauración del vínculo entre imaginación y memoria es el método que ella usa para revelar la vida interior de la diáspora afro-americana de Estados Unidos: primero, usa sus propias memorias y las de otras personas; en un segundo momento, usa la imaginación para complementar las memorias. Este método es similar a la arqueología. Se excava un sitio, y se descubren los restos de la antigüedad. Para restituir este sitio a su aspecto anterior, el arqueólogo pega los restos con los otros por un "adhesivo" de la imaginación y reconstruye una escena 
del pasado. De igual manera, uno excava sus memorias y las de otras personas, y combina unos fragmentos del pasado con otros por la imaginación, así reconstruye la vida interior de la gente que vivía en ese lugar. En cierto sentido, como sostiene Rushdie, el mundo que se reconstruye de este modo es una "ficción" o un producto de la imaginación o la invención, ya que no se reconstruye lo que era o lo que ocurrió realmente.

En el caso de las narraciones nostálgicas de Guadalupe Gutiérrez de Mantecón sobre el pasado y la tierra natal, los objetos del olvido son el presente, la presente vida urbana, solitaria y de envejecimiento, el pasado inmediato, los aspectos negativos de la vida rural tradicional. En cambio, recuerda el pasado remoto, particularmente su infancia, la convivencia con la naturaleza, el calor humano, el amor de sus padres y de su marido ya fallecidos, la forma de vida rural arraigada en la religiosidad. En esta narración nostálgica, el presente no sólo es el tiempo que se olvida, sino que es el punto de partida del cual el sujeto olvida y omite algunos elementos de la tierra natal distanciada tiempo-espacialmente y selecciona y edita el tema, personajes y el paisaje. La autora misma reconoce que en este modo de reconstruir su tierra natal a través de recuerdos hay una idealización del pasado de su tierra natal debido a la selección de los temas y la omisión de los aspectos negativos de la vida rural.

Y no voy a negar que en este retablo de égloga faltaran las tonalidades oscuras: el vicio, la dureza, el machismo. Había de todo; pero ¿en qué clase de sociedad no lo hay? Sin embargo, a la distancia, se vela y se disculpa, o se acepta con mínima indulgencia aquello que se sale de la regla. ${ }^{49}$

\section{NOSTALGIA DE CONTRASTE}

Señalar la diferencia y contraste entre Jalostotitlán y el lugar de residencia actual fuera de su tierra natal también es una forma muy común de manifestación de la nostalgia hacia su patria chica entre los ausentes. Por ejemplo, una de las cosas del lugar de origen que los ausentes de Estados Unidos añoran más es la comida. Aunque hoy en día se pueden conseguir casi todos los alimentos mexicanos en sus localidades en el sur de California, reconocen la diferencia de

\footnotetext{
${ }^{49}$ Gutiérrez de Mantecón (2003: 96).
} 
sabor. Por ejemplo, el hijo de un migrante que radica en La Habra, el condado de Orange, me comentó que ahí podían conseguir el mismo tipo de crema y queso que se consumen en México, pero no tenían el mismo sabor que los productos de Jalos. Estos productos sabían mejor allá porque los alimentos del ganado y la forma de criarlos eran diferentes en Estados Unidos.

Otro tema importante acerca del cual los ausentes comparan la sociedad receptora y su terruño al manifestar la nostalgia es la familia. En el trabajo de campo en California, por ejemplo, conocí a un migrante en "Xalos Bar", un restaurante-bar en Anaheim. Él me comentó lo siguiente: "los mexicanos son muy nostálgicos porque tienen un fuerte apego a la familia, lo cual no tienen los americanos. Ellos se separan y viven solitarios, pero la gente de México no. Por el apego a la familia, la gente extraña y añora su pueblo y regresa a su tierra natal."

Otro aspecto importante del terruño que los ausentes señalaron cuando expresaban su apego a la tierra natal, era la "libertad" de la cual uno puede gozar cuando regresa a Jalostotitlán. En Estados Unidos, cuando organizan fiestas en casa, por las estrictas normas sociales, tienen que estar pendiente con el sonido de la música y la hora en que termina la fiesta para que los vecinos no llamen a la patrulla. Pero, en Jalos, pueden celebrar las fiestas sin preocuparse de esto. También comentaron que en cuanto al consumo de alcohol, las normas sociales son mucho más tolerantes en Jalos que en Estados Unidos. Por ejemplo, en el Libro de los talentos de don Severiano Jáuregui Pérez, aparece la narrativa de una migrante radicada en Anaheim que trabajaba como vendedora de bienes raíces. A pesar de estar satisfecha con su profesión y el "triunfo" que había logrado en su carrera, expresó su añoranza por su tierra natal y sus fiestas locales.

Salí de Jalos hace dieciocho años. Recuerdo las fiestas del quince de agosto con sus juegos pirotécnicos y sus calles adornadas. Añoro las fiestas del carnaval, con sus corridas de toros. Echo de menos los días de salir a comer al campo. ijJalos! Un lugar muy especial. Un sitio donde yo puedo desahogar todas mis frustraciones. Un paraíso donde nos podemos curar de todas las neurosis. ${ }^{50}$

50 Jáuregui Pérez (1981: 20). 
En esta narrativa Jalos se describe como un espacio para desahogarse y librarse y contrasta implícitamente con Estados Unidos como espacio laboral, urbano y de estrés.

Para algunos migrantes, la tranquilidad que existe en Jalos es la razón por la cual prefieren su tierra natal a los actuales lugares de residencia. Un migrante de Los Ángeles quien también vivió en la Ciudad de México, Washington y Chicago, comparó la vida de Jalostotitlán con la situación actual de las ciudades donde él había vivido para explicar la tranquilidad de Jalos, diciendo que en Jalos no hay sismo, terrorismo ni secuestro como en otros lugares.

En contraste con la descripción de su tierra natal como un lugar tranquilo, Estados Unidos se describe como un espacio de soledad y de rutina. Por ejemplo, en el Libro de los talentos de don Severiano Jáuregui Pérez, aparece la siguiente narrativa de un migrante radicado en Huntington Park, el condado de Los Ángeles, quien en el momento de la entrevista llevaba once años en ese país: "de todas maneras no me gusta esta nación para vivir siempre. Se vive muy alejado de parientes y amigos. Además, la vida es demasiado monótona, extremadamente rutinaria. Si estuviera rodeado de todos mis parientes y amigos, sería más feliz en esta tierra tan extraña." (Jáuregui Pérez, 1981: 134).

Desde mi punto de vista, un factor importante que afecta la forma de narrativa comparativa entre la vida de "aquí" y "allá" son las contradicciones que viven los migrantes. Muchos migrantes reconocen que Estados Unidos es un país de mejores oportunidades económicas que México y su tierra natal y de alguna manera, se sienten afortunados de estar en ese país. Pero, la contradicción entre sus expectativas, sus proyectos y la realidad afecta su modo de ver dos mundos más allá del criterio económico. Por ejemplo, el migrante de la entrevista citada en el párrafo anterior reconocía que Estados Unidos era mejor lugar que México para trabajar y para buscar mejores oportunidades económicas y llegó con su esposa con la idea de juntar durante seis meses suficiente dinero para abrir un negocio en su tierra natal. Pero, no le fue fácil realizar su proyecto inicial y prolongó su estancia y llevaba once años en el momento de la entrevista que realizó don Severiano Jáuregui Pérez. 
En algunas narrativas de los migrantes sobre la sociedad receptora y el lugar de origen, no sólo se observa la forma de descripción de dos mundos a partir de contrastes, sino también la contradicción entre la aceptación del país receptor y el rechazo y la crítica a la vida en ese país. Por ejemplo, en el Libro de los talentos, aparece la siguiente entrevista de un migrante radicado en Downey, el condado de Los Ángeles:

Definitivamente, yo creo que Estados Unidos es el país de las grandes oportunidades, para todo mundo. Estoy aquí, porque mis padres me trajeron desde niño. Me considero afortunado, porque los padres quieren siempre lo mejor para sus hijos, y si ellos, mis padres, me trajeron aquí quiere decir que esto era lo mejor para mí. Indiscutiblemente que sí. Esta nación ofrece todas las circunstancias favorables para que todos desarrollemos nuestro potencial [...] No sé por qué; pero añoro México. Muchas veces he sentido la nostalgia por nuestro pueblo. Me encantaría vivir allá en Jalos, nuestro querido pueblo. Su ambiente es tan pacífico, sus gentes tan hospitalarias, las calles...las calles tan desmerecidas, materialmente hablando; pero pletóricas de tradiciones y de seres que se recuerdan con agrado. Las costumbres tan sanas de mi tierra, el temor de Dios tan palpable en la conducta de todas las gentes. ¡Yo sueño con vivir en Jalos!... ${ }^{51}$

Por un lado, sentía que era afortunado de estar en Estados Unidos, por el otro, sentía la nostalgia por su tierra natal señalando la tranquilidad del pueblo, la hospitalidad de su gente y las costumbres y tradiciones locales. Aunque en esta parte de la narrativa no menciona la contraparte con la que compara la vida en Jalos, en la segunda parte de la entrevista, expresó su inconformidad y rechazó el espacio urbano tan tenso en el que había vivido en el condado de Los Ángeles durante su juventud.

Durante más de diez años viví en Watts, uno de los barrios más bajos de todo el condado de Los Ángeles, y tal vez de todo el estado de California. Experimentaba inconformidad. Sentía que no era para mí aquel barrio. Advirtiendo el peligro que corría de echar a perder mi vida traté de imitar a los jefes de las pandillas; pero nada más para hacerlos pensar que estaba a su lado para evitarme dificultades, porque vivía entre ellos. Nunca me gustó el barrio. Aceptaba vivir ahí porque sabía que la capacidad económica de mi padre no le permitía llevarnos a mejor barrio; pero nunca me agradó y siempre renegué, dentro de mí mismo, de aquella triste y lamentable situación de vivir en un barrio tan desordenado. Nunca se lo dije a mis padres, porque eso sería tanto como ofenderlos. Y es que a mí me llegaron a corretear muchas veces los negros y los pachucos. Y nunca de los nuncas me sentí a gusto, por eso antes de

51 Jáuregui Pérez (1981: 85). 
casarme compré mi casa y me fui a vivir a South Gate, un barrio mucho mejor. Yo buscaba la paz y la tranquilidad. ${ }^{52}$

Esta parte de la narrativa sobre la vida en un barrio, donde existía una fuerte tensión entre pandillas y grupos étnicos minoritarios, contrasta con la narrativa sobre Jalostotitlán.

Sin embargo, los ausentes no necesariamente hacen comparaciones entre dos lugares o dos mundos sociales y culturales diferentes para narrar la añoranza y el deseo de retorno a su tierra natal, sino también señalan diferencias entre el pasado de su tierra natal y el presente. En las entrevistas con los ausentes que pasaron su infancia y juventud en los años treinta, cuarenta y cincuenta, yo escuchaba en ocasiones la comparación entre un "antes" y un "ahora" al narrar sus recuerdos de la vida en Jalostotitlán en aquellas épocas. En esta forma narrativa, se describía que Jalos antes era muy bonito y tan pequeño que todos se conocían, pero ahora creció tanto que es difícil saber quien es el hijo de tal persona; antes la música que tocaban en las fiestas era muy bonita y diferente del tipo de música que ahora escuchan los jóvenes; antes las serenatas celebradas en la plaza entre los jóvenes eran mejores que las que hacen ahora. ${ }^{53}$

Cabe señalar que en las narrativas nostálgicas de su tierra natal, lo que hace el sujeto no es una simple comparación entre dos lugares o dos tiempos. Más bien, contrastando uno con otro, lo que hace el sujeto es narrar su preferencia por cierto paisaje, estilo de vida, costumbre, relaciones sociales y ciertos períodos del pasado de Jalostotitlán y manifestar sus propios sentimientos positivos hacia el espacio, el paisaje, relaciones sociales, estilo de vida, eventos y la época, a los cuales pertenece el sujeto o perteneció en su infancia o juventud. En las narrativas sobre la nostalgia, el sujeto da más valor al terruño imaginario, es decir, el terruño que el sujeto recuerda y describe en su mente, que a otro lugar y al presente con

52 Jáuregui Pérez (1981: 85, 86).

${ }^{53}$ Las serenatas son una práctica tradicional para buscar pareja celebradas entre los jóvenes en la Plaza de Armas de Jalostotitlán en la noche de los domingos generalmente, pero, durante las fiestas locales se celebra todos los días. Alrededor del kiosco de la plaza, los hombres caminan en una dirección y las mujeres en la otra. Las filas de mujeres caminan alrededor del kiosco para encontrar alguien que le guste y para intercambiar miradas. Cuando un hombre encuentra a una mujer que le guste, la invita salir de la fila o le entrega un ramo de flores. Anteriormente los hombres caminaban en el sentido contrario al de las mujeres. 
los que se compara su terruño. El imaginario es un concepto neutral, no correcto ni negativo. Ni bueno ni malo. No obstante, cuando uno describe en su mente la imagen de su tierra natal y sus recuerdos con nostalgia, lo que describe en su mente no es ya un término neutral. Además de ser una subjetividad que marca la diferencia entre dos términos, la nostalgia es una subjetividad de doble sentimiento: por un lado, existen insatisfacción, disgusto, descontento, decepción por la condición de su vida actual en el destino del desplazamiento; por el otro lado, preferencia, apego y anhelo por el pasado y por el estilo de vida, el paisaje y personas que están ausentes en la vida presente en el extranjero, pero que hay, había o podría haber en la tierra natal. Con la nostalgia uno construye una imagen de su tierra natal en su mente en comparación entre un "aquí" y un "allá", o sea, entre el destino de viaje y el punto de partida y entre el presente y el pasado, pero dando más valor a los segundos términos.

Los objetos de esta forma de comparación pueden ser varios términos: "aquí" puede ser el presente extranjero, la vida urbana, moderna, rutinaria, fría, solitaria y de envejecimiento, Estados Unidos, etc.; "allá" puede ser el pasado, la infancia, la juventud, lo nacional, México, la vida rural, tradicional, comunitaria, de calor humano, etc.

\section{CALENDARIO EMOCIONAL}

Otro punto interesante acerca de la nostalgia de los migrantes relacionado con el tiempo es que la nostalgia es "un estado" de ánimo y es una subjetividad que cambia con el transcurso del tiempo, no es un sentimiento permanente. En otras palabras, aunque en algunos momentos uno cae en este estado de ánimo y añora su tierra natal, en otros momentos no necesariamente siente la nostalgia. Entonces, ¿cuáles son los momentos en que los migrantes han caído en la nostalgia en sus vidas en Estados Unidos?

Lo que he podido observar en las entrevistas con los migrantes originarios de Jalostotitlán (principalmente, con los hombres que radican en Estados Unidos y con las personas que tuvieron experiencias migratorias en Estados Unidos en algún momento de su vida pero actualmente radican en Jalos) es que 
básicamente hay dos tipos de tiempo en que sentían o sienten la nostalgia hacia su tierra natal en sus vidas en Estados Unidos:

El primer tipo de tiempo de la nostalgia para muchos migrantes, no es el tiempo de trabajo, sino el tiempo en que los migrantes están liberados de este tiempo, es decir, el tiempo de ocio. Cuando están trabajando, no añoran su tierra natal por la concentración que requieren sus actividades laborales, pero, después del trabajo, sobre todo, cuando están descansando en casa, extrañan su tierra natal y a las familias y novias que se quedan ahí. Particularmente, para los migrantes solteros que dejaron sus familias en su tierra natal y los migrantes casados que llegaron a Estados Unidos solos sin esposas e hijos, el tiempo que pasan en sus casas en Estados Unidos después del trabajo es el momento en que sienten duramente la soledad y la insipidez de su vida en ese país.

En vez de pasar solos en sus casas la mayor parte de su tiempo de ocio, muchos migrantes comentaron que iban a los sitios de concentración de redes sociales de los mexicanos y de los paisanos de su lugar de origen, como los restaurantes mexicanos, bares, discotecas, las iglesias católicas cercanas, las casas de algunos familiares, y también iban a algunos espacios públicos, tales como centros comerciales, parques, sitios turísticos cercanos. Aunque hay varios motivos para visitar estos sitios entre individuos, uno de los motivos importantes de estas actividades en el tiempo de ocio es evitar estar solos en sus casas durante tanto tiempo, en el tiempo liberado del trabajo cuando sienten la soledad y añoranza por su tierra natal.

Sin embargo, estas actividades de los migrantes fuera de sus casas en el tiempo de ocio, que de alguna manera se podría decir que son un modo de evitar el tiempo de nostalgia en sus hogares, se comparte entre ellos de manera heterogénea debido a varios factores. Por ejemplo, el tipo y la extensión de actividades de los migrantes en el tiempo de ocio varían, dependiendo de la accesibilidad desde sus domicilios en Estados Unidos a los sitios donde se reúnen los mexicanos y sus paisanos, el clima, su capacidad de comunicación en inglés, si cuentan con los papeles legales en ese país, o suficientes recursos económicos, 
la información, las redes sociales estrechas con los paisanos y si tienen familiares y amigos que vivan cerca de sus casas o no.

Por ejemplo, dos hermanos (de aproximadamente sesenta años de edad) que tuvieron experiencias migratorias en Washington, Chicago y Los Ángeles en los años setenta (el hermano mayor tenía 65 años viviendo en Jalos y el menor tenía 61 años radicado en Los Ángeles en el momento de la entrevista en agosto de 2004 en Jalostotitlán) me comentaron que no sentían la añoranza por su tierra natal cuando estaban trabajando porque estaban muy concentrados en sus labores, pero sí pensaban seguido en Jalos y lo extrañaban cuando estaban descansando en su casa. Cuando vivían en Chicago entre 1976 y 1978, el mayor trabajaba en una fábrica de galletas e iba con frecuencia a los restaurantes mexicanos y a los parques y a ver a sus parientes radicados en la ciudad, y en ocasiones iba al Lago de Michigan los fines de semana. Pero, en invierno tenían que estar encerrados en casa viendo la televisión o comiendo porque no podían ir a trabajar por la nieve y no había algunos sitios cercanos de su casa donde se reunieran los mexicanos como la iglesia católica.

Otro migrante que igualmente estuvo en Chicago durante dos años en los años setenta me comentó, dejándose llevar por una emoción profunda, que no le podía gustar mucho el paisaje urbano invernal de Chicago, donde los coches aplastaban la nieve recién acumulada en las calles cambiando el color blanco de la ciudad por el gris, porque le provocaba melancolía. En este comentario sobre el invierno de Chicago que de repente hizo en la entrevista, se reflejan los recuerdos oscuros de su estancia de dos años en esa ciudad. Para él, estos dos años fueron el período en que estuvo más alejado de su tierra natal en su vida migratoria de más de 30 años. Se fue por primera vez a Estados Unidos en 1970. Llegó a Vallejo, una localidad cercana a Sacramento, California, donde vivía su hermana. En el año siguiente regresó a Jalos y se casó. Por un tiempo estuvo viviendo con su esposa en Jalos. Pero decidieron ir al Norte porque querían conocer más del país sobre el cual siempre le habían hablado a él su familia y parientes que habían estado en Estados Unidos durante su infancia. Llegaron a Chicago, ahí fue donde comenzó a trabajar como mesero, un trabajo que le permitía practicar su inglés. 
Así estuvieron en Chicago durante dos años como indocumentados. Ahí nacieron dos de sus hijos. Después de haber regresado a Jalos y estar por un tiempo en su tierra natal, en 1976, se fueron a vivir a Los Ángeles. La estancia en esta ciudad duró más de diez años. Luego, se fueron a La Quinta, una ciudad ubicada en el condado de Riverside, trabajando hasta la fecha en un country club como mesero durante más de 15 años.

Durante más de 30 años de su vida migratoria en ese país, siempre ha regresado a Jalos, por lo menos, una vez al año, sobre todo, en agosto. La única excepción fue el agosto de 1999, cuando estaba esperando la expedición de su ciudadanía estadounidense, y el período en que estuvo durante dos años en Chicago en los años setenta. Particularmente, cuando estaba en Chicago, tenía que permanecer en ese país porque él y su esposa estaban arreglando su estatus migratorio. Pero su estancia en Estados Unidos se interrumpió cuando recibió la noticia del fallecimiento de su padre y decidieron a regresar a su tierra natal.

Este migrante también me comentó que en ese período era difícil mantener la comunicación inmediata con su familia de Jalos. Ahora que puede hablar por teléfono con sus parientes de Jalos cada vez que extraña su tierra natal, en aquella época la tarifa de la llamada internacional era muy alta, y se cobraba casi 50 dólares para hablar durante una hora. Por eso, usaban más el servicio postal y le escribía a su familia cuando la extrañaba y recordaba a su tierra natal. Usaba la llamada internacional sólo en el caso de alguna emergencia. Esto es el recuerdo de una etapa difícil de su vida migratoria y las experiencias de mayor separación de su lugar de origen, y es lo que la narrativa sobre el invierno de Chicago le hizo recordar.

En cuanto a otro tipo de tiempo de nostalgia que pude observar en las entrevistas con los migrantes, es que hay temporadas en que muchos de los jalostotitlenses radicados en Estados Unidos han caído en este estado de ánimo. Por ejemplo, un joven de 20 años de edad que tuvo una experiencia migratoria me comentó que cuando acababa de llegar a California, al principio estaba muy emocionado, pero, después, casi todo el tiempo quería regresar a Jalos. Él ya contaba con muchos miembros de su familia con experiencias migratorias en el 
momento de su llegada. De hecho, algunos de sus parientes vivían en California cuando estaba trabajando ahí y era una experiencia migratoria insertada en las redes sociales densas de los paisanos. Los primeros 15 días de su llegada, consiguió un trabajo en una compañía de construcción en Vallejo, donde una persona originaria de su tierra natal trabajaba como "mayordomo" (jefe del grupo de trabajadores, en inglés foreman) y rentó una casa con sus amigos de Jalos.

Su rutina era comenzar a trabajar a las 5:30 de la mañana y salía del trabajo a las 6:00 de la tarde. En el tiempo de descanso, iba a algún lado para comer, a discotecas, centros comerciales y ver a sus familiares. Esta vida migratoria duró un año y medio sin haber regresado ninguna vez a su tierra natal. Para él, durante este tiempo el anhelo por el retorno era más fuerte particularmente en agosto y en la temporada navideña. Después de un año y medio de estancia en ese país, decidió regresar a Jalos, y en el momento de la entrevista en agosto de 2004, estaba trabajando con su tío en una tienda de muebles que administraba su familia.

Los migrantes con quienes me entrevisté en California también comentaban que el momento en que sentían la nostalgia de su terruño era cuando tenían que permanecer en Estados Unidos los meses de agosto y febrero. Por ejemplo, para un migrante casado que tiene un hijo y un negocio de imprenta en Anaheim, su tiempo de nostalgia es en estos dos meses en que se celebran las fiestas locales en Jalostotitlán. Sobre todo, en temporada de carnaval es cuando extraña más a su tierra natal que en otros períodos del año. En las fechas en que la gente está festejando el carnaval, muchas veces su mente viajaba a Jalos, pensaba que ahora en Jalos ya comenzaron corridas de toros e imaginaba el paisaje de esta festividad en su terruño.

A pesar de vivir en Anaheim, una de las ciudades donde se concentran más las redes sociales de los jalostotitlenses en California y regresar una vez al año a su tierra natal, ¿por qué este migrante siente la nostalgia? Me explicó que cuando era joven, se divertía mucho en el carnaval, pero ahora que tiene esposa, hijo y negocio, es muy difícil regresar a Jalos en temporada de carnaval porque no es el período en el que caen días festivos en Estados Unidos. Las fechas del retorno 
tienen que ser en agosto o en otro período del año cuando puede tener vacaciones largas. Otro punto importante que señaló este migrante es que aunque regresa a su tierra natal, ya no puede divertirse y comportarse de la misma manera como cuando era soltero porque ahora tiene una esposa y un hijo que cuidar. El hecho de que ahora tiene más responsabilidad dentro de la familia y en el trabajo le dificulta ausentarse de Estados Unidos para asistir al carnaval de Jalos y divertirse como antes y se lamenta por el sentido de distancia temporal y espacial en temporada de esta festividad local.

Pero también me comentó que ahora ya no se ponía tan triste como antes porque ya podía aceptar que tenía que permanecer en Estados Unidos cuando hay cosas más importantes que cumplir y que ya se divirtió bastante cuando era joven. Según él, su caso es aún mejor que el de muchos otros migrantes. Los migrantes que pueden regresar a Jalos en algún período del año son afortunados en comparación con los migrantes que se lamentan por no poder regresar porque todavía les faltan dos o tres años para juntar dinero o para arreglar papeles. Su caso es aún mucho más favorable que el de los migrantes solteros que no tienen estatus migratorio legal porque muchos de ellos no han regresado a Jalos durante cuatro o cinco años, ni saben cuándo podrían salir de Estados Unidos y porque no pueden gozar del carnaval en su juventud. Se dice entre los migrantes jalostotitlenses que hoy en día el riesgo y el costo del retorno son más altos para los indocumentados que antes. Para regresar a Jalos, tienen que juntar 3000 o 4000 dólares para pagar al coyote de regreso a California, además de tener que pagar la renta, cubrir otros gastos y ahorrar el dinero que van a gastar en Jalos. Aunque le paguen al coyote, no hay ninguna garantía de que logren estar de nuevo en los mismos lugares y trabajos que tenían antes de salir del país, debido a la situación actual de la frontera en que se vuelve cada vez más severa la vigilancia fronteriza por las autoridades de Estados Unidos. Por eso, muchos de los indocumentados se enfrentan con la dificultad de realizar su retorno temporal y tienden a prolongar su estancia en ese país.

En suma, la temporada en que viven con mayor nostalgia los migrantes originarios de Jalos en Estados Unidos es la temporada en que se celebra el 
carnaval en su tierra natal, el mes de agosto cuando se festejan las fiestas patronales y la temporada navideña de diciembre. ${ }^{54}$ Lo interesante es que este calendario emocional de los migrantes coincide con el calendario ritual de su lugar de origen. Los migrantes sienten más nostalgia hacia su terruño en estos períodos en que se dan los eventos religiosos importantes y el carnaval en el calendario ritual de la localidad de origen cuando no pueden estar ahí porque vienen uno tras otro varios factores que les dificultan a los migrantes realizar el retorno y les obligan a permanecer en el país del norte, tales como, la responsabilidad y papel que tienen que cumplir dentro de su hogar en Estados Unidos, el trabajo, la falta de recursos económicos disponibles para el viaje, la estricta vigilancia en la frontera, etc. Si la nostalgia es un sentimiento que surge de un dilema entre el deseo de regresar y la imposibilidad de cumplirlo, es necesario entender por qué los migrantes desean estar en su tierra natal cuando se celebran los rituales. Aquí me detengo para analizar los significados de las fiestas locales para los migrantes.

\section{4-1. Significado de las fiestas patronales para los migrantes}

Agosto es el mes en que durante más de 15 días se celebran los ritos religiosos más importantes en la parroquia de Jalostotitlán cuya patrona es la Virgen de la Asunción. Todas las mañanas del primer día del mes hasta el día 15 se celebran las mañanitas a la Virgen, las que cada uno de los ocho sectores de la parroquia de Jalostotitlán se encarga de organizar en dos días seguidos. Los encargados y los habitantes de cada sector llevan cargando una réplica de la imagen de la Virgen al templo parroquial acompañados con la banda municipal, y a las seis de la mañana comienza la misa.

Del día primero al 14 de agosto, se hace una peregrinación en el día y otra peregrinación en la tarde. Las peregrinaciones que se celebran antes de la misa de 12:00 de la tarde se llaman peregrinaciones de los campesinos, en las cuales participan los habitantes de las rancherías de Jalos. Las peregrinaciones que se

${ }^{54}$ Como en otros lugares del mundo donde se celebra el Carnaval, en Jalostotitlán el Carnaval se centra en tres días antes del miércoles de ceniza aunque en los últimos años se ha ampliado una semana más. Las fiestas de la Virgen de la Asunción se celebran durante la primera quincena del mes de agosto. 
hacen antes de la misa de la tarde son para los habitantes de otras dos parroquias que existen dentro de la cabecera municipal y para varios gremios, los jóvenes, señoras y las personas que llevan el nombre de Asunción. Para todas estas peregrinaciones, se usa la réplica de la imagen de la Virgen de la Asunción

El 15 de agosto es el día más importante de las fiestas patronales dedicadas a la Virgen de la Asunción. Para esta ocasión, se saca de la iglesia la imagen original de la Virgen. Es el único día durante todo el año en que se saca la imagen original del altar de la iglesia y se realiza la Procesión con la Imagen de la Santísima Virgen de la Asunción, recorriendo las principales calles de la ciudad. Es una peregrinación de mayor escala que otras, dado que gran parte de los habitantes de la parroquia y los retornados temporales que llegan de Estados Unidos y de otras partes de la República Mexicana forman la procesión que recorre la mayor distancia de las principales calles de la cabecera municipal. Después de regresar al templo parroquial, la imagen de la Virgen se coloca en la escena establecida fuera del templo y se celebra la misa, no en el interior del templo, sino en su exterior, y la gente está de pie en la plazuela de enfrente del templo.

Varios de estos ritos dedicados a la Virgen de la Asunción no sólo son para dar gracias a la Virgen, pedirle las mandas y venerarla, sino que son ocasiones en que a través de la preparación, organización y participación en los ritos, se crean y se refuerzan la identidad religiosa y los lazos sociales y emocionales más allá del sentido de pertenencia a un solo grupo social o sector de la parroquia. El efecto de comunitas del rito del día 15 de agosto les permite a los jalostotitlenses compartir el sentido de pertenencia a la tierra que reina la Virgen de la Asunción con otros habitantes y reafirmar la identidad local. ${ }^{55} 56$

${ }^{55}$ Maria Ana Portal Ariosa (1994) propone ver peregrinaciones como un sistema de intercambio simbólico que facilita la recreación de identidades sociales, a través de la fijación de límites culturales que señalan el adentro y el afuera del grupo.

${ }^{56}$ Turner (1969) enfoca en la fase de transición o la fase liminal, una de tres fases del rito de paso que propuso Arnold van Gennep (1960). Sostiene que en este proceso liminal del rito, se anulan las relaciones sociales, papeles y posiciones estructurados de manera jerárquica por los factores políticos, jurídicos y económicos en la vida cotidiana y se construyen lazos sociales y emocionales más comunitarios. Para consultar el concepto de comunitas, también véase Turner (1974: 231-271). 
El día 16 de agosto se celebran la peregrinación y la misa para los hijos ausentes. Este rito cumple la función de reincorporar a la parroquia a aquellos jalostotitlenses que radican en Estados Unidos y en otros lugares de México y reforzar el sentido de pertenencia a la parroquia de Jalostotitlán. ${ }^{57}$

Estos son los eventos religiosos principales de las fiestas patronales. Pero, aparte de estos, durante las fiestas también se celebran otros ritos religiosos, tales como, bautismos, primeras comuniones, confirmaciones, bodas, quinceaños. Estos ritos de paso no se realizan diario en el templo parroquial. Ciertos días del mes de agosto están asignados para bautismos, primeras comuniones y confirmaciones, por tanto, estos eventos se celebran de manera colectiva juntando a varios niños a la vez en el templo. Por ejemplo, del día primero al 15 de agosto de 2004, en el Templo parroquial de Nuestra Señora de la Asunción se realizaron las primeras comuniones de aproximadamente 300 personas y Confirmaciones para casi 400 personas. El día 8 de agosto del mismo año 20 niños fueron bautizados. Del día primero al 31 de agosto del mismo año, se celebraron 23 matrimonios, 13 quinceaños, una boda de oro y dos bodas de plata. Según la notaría de la parroquia, el número de estos ritos es mucho menor fuera de temporada de fiestas de agosto. Según el registro civil de la presidencia municipal, se registran aproximadamente 180 casos de matrimonio al año en todo el municipio. Si se pensara que 180 parejas que se casan por el civil organizan el matrimonio religioso en el mismo año, se podría decir que casi 13 por ciento de las parejas recién casadas por el civil realizan su matrimonio religioso en una sola iglesia de la cabecera municipal durante un mes a pesar de que existen varias otras iglesias en el municipio.

La razón por la cual se concentran los ritos de paso en el mes de agosto, según la notaría de la parroquia y los habitantes de Jalos, es porque muchas familias prefieren organizar estas fiestas religiosas cuando regresan en agosto muchos de sus familiares que viven en otros lugares de México y en Estados Unidos para poder invitarlos a las fiestas. En ese caso, tienen que solicitar la fecha

${ }^{57}$ Explicaré con más detalle el día de los hijos ausentes en el capítulo 4. 
de la celebración a la notaría de la parroquia con mucha anticipación. Si no, no pueden recibir la fecha que desean debido al número mayor de interesados.

En este sentido, el mes de agosto es el período de reencuentro de los habitantes de Jalos con sus familias y parientes que salieron a otras ciudades del país y a Estados Unidos. También es un período de reencuentro con sus amigos y sus novios (as).

Un migrante radicado en Turlock me explicó que el mes de agosto es una época de mucha alegría. ¿Cuál sería el motivo de esta emoción? Es la alegría de haber podido ver de nuevo la imagen de la Virgen de la Asunción y celebrar sus fiestas. Es la alegría de que toda la ciudad reciba su bendición. Pero, la alegría que los jalostotitlense pueden sentir en esta temporada del año no es simplemente una emoción en el sentido religioso, sino que tiene un significado social más amplio. Es una emoción en la que incluyen la alegría de poder compartir el sentido de pertenencia con otras personas que tienen trabajos y experiencias diferentes, la alegría de poder reencontrarse con sus seres queridos, la alegría de poder festejar los ritos de paso con sus familias, la alegría de poder enseñar las tradiciones y costumbres de su tierra natal a sus hijos nacidos y crecidos en Estados Unidos. En suma, agosto es la temporada de alegría en el calendario emocional de los jalostotitlenses.

Otro punto importante de las fiestas religiosas de agosto en que se organizan varias peregrinaciones es que, de alguna manera, el retorno temporal de los migrantes en sí es una peregrinación. La peregrinación es la caminata devota que hacen los peregrinos. El término peregrino procede de la palabra latín peregrinus, que significa extranjero (Quiroz Malca, 2000: 14). Si la peregrinación es un viaje y un recorrido que se realiza desde el extranjero o de algunos lugares lejanos a un lugar sagrado para venerar y agradecer a alguna imagen religiosa, el retorno temporal de los migrantes en agosto es una peregrinación, dado que en esta temporada toda la ciudad Jalostotitlán se convierten en lugar sagrado y que uno de los motivos principales de este viaje es religioso.

Turner y Turner (1978) sostienen que la peregrinación tiene algunos atributos de la fase liminal del rito de paso. Es decir, en la peregrinación, los peregrinos se 
convierten en seres que están liberados de la relación social jerárquica de la estructura social secular, de las normas sociales y de las posiciones y los papeles sociales en la vida cotidiana, por lo que se construyen lazos sociales más igualitarios. Lo interesante de esta consideración es que originalmente, en el significado local, las fiestas patronales de agosto son una festividad que consiste en las peregrinaciones en las que se suspenden la relación social, las posiciones y los papeles sociales que ocupan los individuos dentro de la estructura social de la vida cotidiana, y los individuos de diferentes sectores, profesiones y experiencias se convierten en los habitantes de Jalos igual que otros ante la imagen de la Virgen de la Asunción para reafirmar su identidad social en esta fase liminal del rito.

Pero los migrantes que regresan de Estados Unidos realizan la peregrinación utilizando su tiempo de ocio. Lo que se suspende para liberarse de las relaciones, posiciones y papeles sociales temporalmente en la estructura social secular, es la vida cotidiana de los migrantes en Estados Unidos, donde ocupan posiciones sociales como trabajadores del grupo minoritario y donde están sujetos al trabajo y las normas sociales de ese país.

$\mathrm{Si}$ entendemos los significados que dan los migrantes a las fiestas locales de agosto, podemos entender que el hecho de no poder regresar a su tierra natal en esta temporada tendría implicaciones profundas: la pérdida de la oportunidad para liberarse de la cotidianeidad sujeta al trabajo y a las normas sociales en Estados Unidos; la pérdida de la oportunidad para liberarse de la posición social como trabajadores extranjeros del grupo minoritario en la sociedad estadounidense; la pérdida de la oportunidad para reforzar lazos sociales con los habitantes del lugar de origen y para reafirmar la identidad religiosa y el sentido de pertenencia a la tierra natal; la alienación del tiempo y espacio de la alegría que pueden sentir al reencontrar a sus seres queridos y festejar con ellos este período del año dedicado a la Virgen de la Asunción. En esta temporada, la tristeza y la nostalgia de los migrantes surgen del contraste entre el yo ideal, que debería de estar en su tierra natal gozando del tiempo y espacio de las fiestas locales, y otro yo que se 
enfrenta con la realidad de no poder estar ahí y no poder saborear la alegría colectiva.

La temporada navideña de diciembre es otro período del año en que los migrantes experimentan la nostalgia provocada por el contraste en el caso de que tengan que permanecer en Estados Unidos. Particularmente, aquellos migrantes que llegaron solos a Estados Unidos sin familia viven un doble contraste, es decir, el contraste entre un yo que debería estar festejando la navidad con su familia en casa si estuviera ahora en Jalos, y otro yo, que recibe la navidad de manera solitaria en Estados Unidos, y entre la gente que celebra la navidad con la compañía de sus familias y novias en Estados Unidos y ellos que pasan vacaciones de diciembre sin estar con su familia.

\section{4-2. Significados del carnaval para los migrantes}

Ahora bien, el carnaval es otra festividad local importante en la que Jalostotitlán recibe a un gran número de visitantes que llegan de las localidades vecinas de la cabecera y de otros municipios de los Altos de Jalisco y muchos ausentes radicados en Estados Unidos. Sin embargo, este ritual tiene un sentido social diferente de las fiestas locales de agosto. Mientras que las fiestas patronales son un ritual en que los jalostotitlenses reafirman la creencia, los valores y las normas religiosas, el carnaval es un ritual que libera a la gente de la cotidianeidad sujeta a las normas religiosas.

El carnaval se festeja durante los tres días anteriores al miércoles de ceniza. Por lo general, se entiende que es un ritual que suspende la vida cotidiana que está estrictamente sujeta a las normas religiosas entre el adviento y los cuarenta días de la cuaresma. En este tiempo "liminal", se invierten las normas católicas, tales como, sobriedad, abstinencia, penitencia, en cambio, el exceso y el placer se convierten en los valores que dominan los comportamientos de los individuos. Es una fiesta de renovación que representa la continuidad de la vida al volver simbólicamente al caos. Asimismo, es una fiesta colocada en el ciclo agrícola cuya objetividad es celebrar la llegada de la primavera y la reproducción así como 
romper las normas sociales de la vida cotidiana al seguir al exceso, el placer y el consumo del vino. ${ }^{58}$

Esta fiesta de origen mediterráneo llegó a este continente en el proceso de la conquista, y se difundió en distintos lugares del continente, tales como, Río de Janeiro, Nueva Orleáns, Veracruz, Mérida, Mazatlán, otros lugares de México, etc. Según la libreta sobre la historia del carnaval de Jalostotitlán publicada por la presidencia municipal de Jalostotitlán en el año 2003, la tradición del carnaval de Jalos es tan antigua como la llegada de los españoles a los Altos de Jalisco, y en 1572 se estableció el carnaval en Jalostotitlán. Se explica el significado del carnaval de Jalos del siguiente modo, enfocándose en su función ritual dentro del contexto religioso del catolicismo: "El carnaval tiene su origen en un contexto religioso como una fiesta que permitía gozar de los días previos al miércoles de ceniza, ya que el período cuaresmal era muy riguroso, de ahí el que la fecha de esta fiesta sea variable de acuerdo al calendario litúrgico de la Iglesia Católica" ${ }^{59}$

Por su parte, el cronista Víctor Manuel Jiménez considera que el carnaval de Jalos es un producto del paralelismo y mestizaje de festividades de origen mediterráneo con la fiesta de Tlacaxipehualiztli dedicada a Xipetotec, el dios de la renovación de la tierra, que se celebraba entre los tecuexes que gobernaban la zona en la que se ubican Jalostotitlán y sus lugares vecinos, en el inicio del ciclo agrícola, en el segundo mes del calendario azteca. ${ }^{60}$

De cualquier modo, el actual carnaval de Jalostotitlán es una festividad local que atrae aproximadamente a 10,000 visitantes, y se celebra no sólo en los tres días previos al miércoles de ceniza, sino que empieza casi una semana antes con la realización de varios eventos, tales como, el certamen de belleza, el desfile inaugural, juegos mecánicos, la exposición ganadera, industrial y artesanal, las peleas de gallos y los conciertos de los cantantes mexicanos, charreadas, corridas de toros, el teatro del pueblo, etc. Aparte de estos eventos, todas las noches se da en la Plaza de Armas la serenata, una ceremonia tradicional que se practica entre

${ }^{58}$ La "liminalidad" y la "subversión de las normas sociales y las relaciones y posiciones sociales" estructuradas en la vida cotidiana son elementos fundamentales del carnaval como ritual. Véanse Caro Baroja (1979), Eco et al. (1984), le Roy Ladurie (1979) y Turner (1974).

${ }^{59}$ H. Ayuntamiento de Jalostotitlán (2003: 13).

${ }^{60}$ Víctor Manuel Jiménez, 2006, "La fiesta de Xipe o Carnaval”, Revista Seis, p.3. 
jóvenes para buscar novios y novias. Se establecen en la misma plaza terrazas, puestos de venta de bebidas alcohólicas. Esta plaza, cantinas, bares y discotecas se llenan de gente y el enorme gentío que hay en el centro de la ciudad durante el carnaval dura hasta casi la madrugada.

En contraste con las fiestas locales de agosto organizadas principalmente por la autoridad eclesiástica local, el carnaval se organiza por la participación del sector comercial local y por la coordinación de la autoridad civil local, es decir, la presidencia municipal.

Esta temporada de festividad local también es un período en que llegan un gran número de ausentes radicados en Estados Unidos y en otros lugares de México, sobre todo, durante el carnaval hay una fuerte presencia de jóvenes originarios de Jalostotitlán. Para los migrantes solteros de Estados Unidos, es una temporada importante para desahogarse del estrés y liberarse de la vida cotidiana como trabajadores extranjeros, buscar novias y profundizar el noviazgo. En este sentido, es necesario analizar los significados de esta festividad local para los migrantes y la nostalgia que experimentan en tiempo ritual de la tierra natal desde el ángulo generacional.

\section{NOSTALGIA EN TÉRMINOS GENERACIONALES}

\section{5-1. Nostalgia de los jóvenes}

El carnaval de Jalostotitlán es una festividad cuyas características fundamentales consisten en el exceso de consumo de bebidas alcohólicas, diversión, música y el placer, los cuales son comportamientos contrarios a los que las normas religiosas controlan en la vida cotidiana. La característica esencial de este ritual es la suspensión y la liberación de las relaciones, normas, posiciones y papeles sociales dentro de la estructura social de la vida cotidiana. Una de las expectativas de los migrantes masculinos de Estados Unidos sobre el carnaval tiene que ver precisamente con esta característica del ritual.

En el apartado anterior, yo había explicado la nostalgia que se basa en el contraste entre Estados Unidos como espacio de estrictas normas sociales y Jalostotilán como "espacio de libertad". Este "espacio de libertad" no se refiere al 
Jalostotitlán de la cotidianeidad, sino la tierra natal del tiempo ritual y de fiestas. El contraste se marca entre la vida cotidiana de Estados Unidos, donde los comportamientos de los migrantes están sujetos a las estrictas normas sociales, al tiempo de trabajo, a la moderación del consumo y al ahorro, y el tiempo del carnaval de la tierra natal, en el que se divierten con sus amigos tomando en exceso bebidas alcohólicas, en las cantinas, bares, discotecas y terrazas, recorriendo las calles con las bandas comerciales, llamadas tamborazos, que tocan música a un alto volumen. En el tiempo y espacio de esta fiesta local, se anulan los comportamientos moderados de los migrantes para desahogarse del cansancio y estrés acumulado durante su estancia en Estados Unidos y liberarse de la soledad, las estrictas normas sociales y la vida rutinaria en ese país.

Por el otro lado, para los migrantes jóvenes, el retorno temporal es una importante ocasión para la diferenciación social con los habitantes de su lugar de origen enseñando la ropa de moda, las camionetas y otros productos que habían comprado y el estilo de vida y las ideas adquiridos en el país del norte. Esta expectativa de diferenciación social al retornar no sólo se limita a los migrantes jóvenes ni a la temporada del carnaval. Para muchos migrantes, el retorno a su tierra natal en temporada de fiestas locales es, por lo general, la ocasión en que pueden sentir un cambio temporal en su estatus social a través de su capacidad de consumo, su capacidad económica y los productos, ideas e información adquiridos en Estados Unidos. Al parecer, este tipo de comportamiento de los migrantes contradice la idea de que el efecto de comunitas del ritual construye las relaciones humanas más igualitarias. ${ }^{61}$ Sin embargo, en las fiestas locales de Jalostotitlán hay dimensiones en que se observa el comunitas como un atributo de la fase liminal del ritual, también existen dimensiones en que los participantes se convierten, en la fase liminal, en seres sociales con el significado diferente de lo que tienen en su vida cotidiana. En este tiempo ritual, los migrantes reciben un estatus social diferente de lo que tienen en Estados Unidos. Su estatus social de trabajadores extranjeros de un grupo minoritario dentro de la sociedad estadounidense se suspende en la tierra natal en México, y pueden sentir un

${ }^{61}$ En cuanto al concepto de comunitas, véase Turner (1969; 1974: 231-271). 
estatus social mejor gracias a su capacidad de consumo respaldado por los dólares que habían ahorrado en Estados Unidos.

Asimismo el carnaval es una ocasión importante para los jóvenes con el fin de conocer a las mujeres o renovar y profundizar el noviazgo, dado que varios eventos del carnaval les dan pretexto y oportunidades para salir con ellas. Tres migrantes jóvenes solteros con quienes me entrevisté en Anaheim me comentaron que cuando regresaban a Jalos durante el carnaval, gastaban cerca de 1000 dólares en tres días porque salían con sus novias a ver conciertos, a corridas de toros, a tomar y bailar con ellas. Para ellos, la intención de ver a sus novias durante el carnaval no es sólo para pasar bien el tiempo en compañía de mujeres, sino que es algo más serio. Aunque habían conocido a sus novias en su tierra natal, ellos tienen que seguir trabajando gran parte del año en Estados Unidos, por lo que tienen que mantener un noviazgo de larga distancia hablando con frecuencia por teléfono con ellas. Por eso, las fiestas locales son la oportunidad para poder conocer más a sus novias, reafirmar sus sentimientos y profundizar el noviazgo. Ellos pensaban casarse con sus novias de Jalos después de trabajar unos años más en Estados Unidos.

De hecho, hay muchas parejas que se conocieron, se enamoraron y renovaron su noviazgo de larga distancia en temporada de fiestas y llegaron hasta el matrimonio. En este sentido, las fiestas locales cumplen una función social como reforzamiento de los lazos sociales y emocionales entre los migrantes solteros y las mujeres que viven en su tierra natal y contribuyen a la futura reproducción social.

Los motivos del retorno temporal de los jóvenes que he explicado aquí no sólo se limitan al carnaval. Estas expectativas del viaje a Jalos también se incluyen en los motivos del retorno de muchos migrantes durante la temporada de fiestas patronales. De hecho, las fiestas de agosto tienen varios eventos y espacios que permiten materializar estas expectativas a pesar de que el objetivo principal de esta celebración sea religioso. ${ }^{62}$

62 Como explicaré en el capítulo 6, en los años recientes había muchas quejas de parte de los habitantes de Jalostotitlán y los párrocos sobre la "carnavalización" de las fiestas 
En suma, para los jóvenes migrantes, no poder regresar a su tierra natal en el carnaval significa experimentar la alienación provocada por la pérdida de la oportunidad para liberarse del cansancio y el estrés acumulados en la vida cotidiana en Estados Unidos, sentir un ascenso temporal de su estatus social, y comenzar y renovar el noviazgo. Al no poder estar en el tiempo de carnaval en Jalostotitlán, ellos se lamentan por la imposibilidad de su retorno, se entristecen por el dilema entre querer estar ahí y tener que permanecer aquí y por el contraste entre un yo, que debería de estar divirtiéndose mucho con sus amigos y su novia si estuviera ahora allá, y otro yo, que está tomando solo para aliviar el dolor o está mirando solo el cielo de California dibujando la ilusión del paisaje del carnaval y recordando con la nostalgia aquellas épocas en que pudo estar en esta fiesta de su terruño.

\section{5-2. Nostalgia de los viejos}

Por otro lado, los migrantes jubilados que se establecieron con sus familias en Estados Unidos donde ya llevan varias décadas, ahora pasan su vejez en aquel país, sienten de diferente modo el contraste entre la vida en su tierra natal y su vida cotidiana en Estados Unidos y expresan su añoranza por Jalos y su deseo de retorno temporal y/o definitivo.

Un migrante jubilado, que tenía 74 años en el momento de entrevistarlo en el otoño de 2004 en California, ya llevaba aproximadamente cincuenta años viviendo en Estados Unidos desde que llegó a ese país en 1953. En el momento de la entrevista, ya estaba jubilado y vivía con su esposa y una hija en su casa ubicada en el este del condado de Los Ángeles. Cuando trabajaba, regresaba a Jalostotitlán cada agosto. Continúa esta costumbre de retorno temporal hasta la fecha después de su jubilación. Aunque le gustan ambos lugares, su tierra natal y la localidad en California, me comentó que en comparación con la vida rutinaria y solitaria en ese país, tenía más cosas que hacer y más amigos con quien platicar en Jalostotitlán. Sus actividades diarias en Estados Unidos consistían

patronales de agosto debido a la fuerte presencia de jóvenes que buscan materializar más estas expectativas seculares del retorno que demostrar la devoción. 
principalmente en ir solo a la iglesia y a la biblioteca para leer libros en español y cuidar sus plantas en el jardín de la casa entre semana y recibir la visita de las familias de algunos de sus hijos e ir a Tijuana en coche los fines de semana. En contraste con esta vida cotidiana en California, él comentó que en Jalos tenía más actividades, tales como, cuidar un pedazo de terreno agrícola y hablar con parientes y amigos.

Es cierto que Jalostotitlán cuenta con varios sitios de actividades para la gente de la tercera edad: las iglesias donde los mayores juegan papeles importantes dentro de los grupos adoradores, la plaza donde se reúnen los ancianos para platicar con sus amigos sentados en las bancas desde la mañana hasta la hora de comida, la presidencia municipal, las cantinas donde platican y juegan domino con sus amigos, el taller de reparación de aparatos eléctricos adonde van los amigos y vecinos para conversar con el dueño de distintos temas, las actividades recreativas que organiza el DIF municipal y el taller de baile folklórico donde los integrantes de la tercera edad ensayan su presentación para las fiestas de agosto, etc. En suma, Jalostotitlán es un espacio social donde está más abierta la participación en las actividades sociales para la gente de la tercera edad que en Estados Unidos.

Por el otro lado, en la vida cotidiana en Estados Unidos, los migrantes jubilados están liberados de actividades laborales y los roles sociales dentro del hogar porque ya no trabajan y porque sus hijos crecieron y salieron de sus casas para formar sus propias familias. Asimismo, hay algunos factores que les obstaculizan a los migrantes jubilados tener actividades sociales fuera de sus hogares, tales como, falta de la alta capacidad de comunicación en inglés, la brecha generacional, en algunos casos particulares, el estado de salud de los migrantes y/o de sus esposas, la situación económica no favorable entre otros. En cierto sentido, muchos migrantes jubilados experimentan la soledad y la alienación social debido a esta dificultad de tener nuevos papeles sociales y crear vínculos sociales dentro la sociedad receptora. Un migrante jubilado radicado en el condado de Orange durante cerca de cinco décadas me comentó que sería mejor pasar la vejez en Jalostotitlán que en Estados Unidos porque a diferencia de las 
personas que envejecen en su lugar de origen, muchas personas se mueren de repente cuando cambian el ritmo de vida y actividades después de la jubilación.

Otro punto interesante de las narrativas de los migrantes jubilados es que no sólo comparan su tierra natal con otros lugares, sino que contrastan la época en que ellos crecieron en Jalos con la actualidad de otros lugares. Dicen que en su infancia en Jalos sus padres les inculcaban la costumbre de respetar a los mayores, pero hoy en día muchos valores tradicionales como este se han perdido por las influencias de la televisión y el estilo de vida moderna en donde viven ellos actualmente, y sobre todo, los jóvenes de hoy en día no comparten el valor tradicional del respeto a los mayores.

Por ejemplo, un migrante jubilado del condado de Orange se enfrentó con la carencia de este valor tradicional entre los jóvenes mexicanos en el lugar laboral cuando trabajaba temporalmente en una fábrica para juntar dinero para cubrir los gastos de su viaje a Jalostotitlán. Aunque tenía la experiencia de haber trabajado varias décadas en otros lugares antes de su jubilación, se dedicó al mismo tipo de labor y puesto que un grupo de jóvenes mexicanos indocumentados que llegaron de otros estados de México. Ellos siempre le decían "abuelo" sin respetar la edad de este migrante jubilado y sus experiencias de vida acumuladas en Estados Unidos. Lo que quiero señalar con este ejemplo es que la pérdida del valor tradicional del respeto a los mayores no sólo tiene que ver con la diferencia generacional, sino con el contexto laboral de la fábrica, donde para el tipo de labor que realizaban este migrante jubilado y los jóvenes no se requerían trabajadores calificados, ni se evaluaban las experiencias laborales previas, o la edad de los migrantes, además del hecho de trabajar con trabajadores mexicanos provenientes de diferentes regiones y ciudades, con quienes no se comparten los valores tradicionales de la región de los Altos de Jalisco.

La idea de Jalostotitlán como espacio social donde predominan los valores tradicionales se refleja en el motivo del retorno temporal a su tierra natal. Por ejemplo, un migrante jubilado de Sacramento, que tenía 72 años en el momento de la entrevista en Jalos en la temporada de fiestas patronales en 2004, comentó que desde 1982 regresaba a su tierra natal cada agosto, y que el motivo del 
retorno anual no sólo era ver a sus padres y familiares, sino también enseñarles a sus hijos las tradiciones y costumbres de su tierra natal. Para él, el respeto a los padres es una "filosofía" de vida y quería transmitirles esta idea tan arraigada en las costumbres de Jalos.

Esta preocupación por la alteración y la desaparición de los valores tradicionales que existían en el ámbito rural en la infancia también la comparten los ausentes nacionales, es decir, los jalostotitlenses que salieron de su tierra natal y se asentaron en otros lugares, sobre todo, en las grandes ciudades dentro del territorio nacional mexicano. Por ejemplo, José Atanasio Gutiérrez y Gutiérrez, un migrante interno originario de Jalostotitlán radicado en la Ciudad de México, aporta el siguiente mensaje para la presentación del libro titulado, La Querencia, de Guadalupe Gutiérrez de Mantecón:

Más aún, podría yo decir que este libro refleja de manera muy acabada un estilo de vida antiguo que se extendió y aún perdura parcialmente en la región de los Altos de Jalisco; me refiero a la suma de costumbre y tradiciones que practicaban nuestros abuelos [...]

[...] el tipo de vida que llevaron nuestros padres y abuelos, dentro de un ambiente campesino de principios del siglo veinte. Quienes, siendo niños, alcanzamos a vivir en algún rancho de Los Altos [...]

[...] Por desgracia, la historia del país, de cincuenta años a esta parte, nos ha permitido ser testigos de cómo estas formas antiguas de vida son de repente distorsionadas y aún barridas por una especie de huracán que quisiera llevarse estilos de existencia consagrados por muchas generaciones de mexicanos.

Pero de cara a cara a esta frustración [...] no pensamos -ni por equivocaciónque todo tiempo pasado fue mejor; sabemos muy bien que la vida moderna ha traído, aunque no para todos, múltiples beneficios y comodidades de que carecieron las generaciones pasadas; pero, a cambio, los costos en varios sentidos han sido enormes, fundamentalmente en los ámbitos familiares y sociales, como a diario lo seguimos lamentando [...] una forma de vida que va quedando rápidamente en desuso en nuestro pueblo y sus rancherías, por lo menos como forma de expresión cotidiana en las relaciones familiares y sociales; particularmente, los de respeto a los mayores y a los compromisos asumidos en la palabra.

Como dije antes, considero que estos fundamentos han sido ya desplazados del centro que ocuparon durante cientos de años, y todo hace pensar que los jóvenes de hoy se mueven, en la vida, orientados por otros valores y llevados por impulsos y objetivos distintos a los que tuvieron nuestros padres y abuelos. Puede esto obedecer a cambios profundos que han dislocado las relaciones sociales y familiares $[\ldots]^{63}$

63 José Atanasio Gutiérrez y Gutiérrez (2003: 8, 12-14). 
Explica que la autora del libro reconstruye a través de los recuerdos de su infancia el estilo de vida tradicional en el ámbito rural que predominaba en la región de los Altos de Jalisco, y que los valores tradicionales ligados a las costumbres y tradiciones regionales de centenarias historias han sido alterados y subestimados por los cambios traídos por la modernidad y las influencias de nuevas formas de vida. Expresa, desde el contexto urbano de la capital del país, la nostalgia hacia el estilo de vida tradicional y el espacio rural del pasado en donde las relaciones familiares y sociales estaban sujetas a los valores tradicionales.

En suma, los migrantes de esta generación experimentan en su vida cotidiana de vejez en las tierras tiempo-espacialmente distanciadas de su tierra natal el sentido de pérdida de los valores tradicionales, tales como, el respeto a los padres y mayores, valores que aún existen en Jalos o existían antes. Entrando a su vejez, a la etapa de vida, donde ellos ahora son el objeto de respeto según los valores tradicionales de su región natal, sienten duramente el contraste entre generaciones y entre la vida durante su infancia en Jalostotitlán que fue sujeta a los valores tradicionales y la vida contemporánea en Estados Unidos más ligada a otros valores. Para los migrantes de esta generación que pasan su vejez en el país del norte, su tierra natal es un espacio en donde ellos pueden tener más actividades y otros papeles sociales dentro de la comunidad local y pueden ser revalorados socialmente, es decir, Jalostotitlán es un espacio de empoderamiento de los migrantes jubilados.

\section{NOSTALGIA EN TÉRMINO DE GÉNERO}

No son pocas aquellas personas que desean volver a su tierra natal para vivir por estas razones entre los migrantes jubilados y los migrantes que aún están en las edades activas para el trabajo, sobre todo, entre los hombres.

Sin embargo, sus esposas por lo general piensan del proyecto de retorno de un modo diferente, cuestionan la idea de retornar a Jalos para vivir después de la jubilación de sus esposos y desean permanecer en Estados Unidos. Hay varias razones por las cuales quieren seguir viviendo en ese país. Por ejemplo, una razón muy importante es porque quieren estar cerca de sus hijos y sus nietos. La 
esposa de un migrante jubilado radicado en el condado de Orange que cuida a sus nietos en el día para ayudar a su hijo y su nuera que trabajan me contestó que quería seguir viviendo cerca de sus nietos cuando le pregunté qué pensaba acerca de la idea de su esposo de regresar a Jalos para vivir algún día. Para ella, cuidar a sus nietos es una de las actividades principales de su vida cotidiana de la vejez y es un papel importante que asume dentro del hogar.

La esposa de otro migrante jubilado radicado en el condado de Los Ángeles comentó que prefería vivir en Estados Unidos a vivir en Jalos porque cuando regresaban su esposo y ella a su tierra natal en vacaciones, ella salía de casa sólo para ir a las misas y ver algunos eventos en las fiestas, pero básicamente estaba en casa platicando con sus parientes, mientras los hombres tenían muchas cosas que hacer fuera de casa.

No sólo son las esposas de los migrantes jubilados las mujeres que prefieren vivir en Estados Unidos a vivir en su tierra natal, sino muchas de las esposas de los migrantes relativamente jóvenes y en edades activas para actividades económicas. Por ejemplo, la esposa de un ex-migrante con hijos menores de edad explicó, comparando los comportamientos de su esposo después del retorno con sus comportamientos en Estados Unidos, la razón por la cual ella quería volver a Estados Unidos. Cuando vivían allá, su esposo casi no tomaba alcohol y siempre estaba con su familia en los fines de semana y la llevaba a pasear muy seguido. Pero, en Jalos siempre está con sus amigos tomando cervezas. Por eso, preferiría la vida de allá a la de Jalos.

Víctor Espinosa (1998), quien describe, a partir de una mirada analítica de relación de género, el dilema y la tensión entre el retorno y el establecimiento dentro de una familia migrante que se ha establecido en una ciudad de Estados Unidos durante 25 años, señala que la participación de las esposas de los migrantes en el mercado laboral ha cambiado los papeles que asumen tanto los hombres como las mujeres dentro del hogar y la tradicional relación de género dentro de la familia en la que los hombres asumían actividades fuera de casa y las mujeres ocupaban papeles y actividades dentro de casa. La participación de las mujeres en las actividades económicas en Estados Unidos no sólo significó un 
ingreso extra para la familia, sino amplió la oportunidad de su participación en la toma de decisión dentro de la familia y ha cambiado la idea tradicional de que las mujeres sólo tienen que ocupar roles relevantes dentro de la casa. Ante esta situación, los hombres también se enfrentan con la necesidad de redefinición de su identidad masculina, dado que aunque en el país de origen ellos eran quienes mandaban a sus esposas, ahora son ellos quienes son mandados ante la creciente toma de decisión de las mujeres dentro del hogar en Estados Unidos.

Para las mujeres migrantes, permanecer en Estados Unidos significa mantener su posición equitativa en la relación de género dentro de la familia, en ocasiones, más ventajosa que la de sus esposos. En cierto sentido, seguir viviendo en Estados Unidos es permanecer en el lugar de empoderamiento femenino, en cambio, el retorno a México significaría la posibilidad de la pérdida de su autonomía dentro de la familia. Por eso, en el caso estudiado, la esposa se opone al proyecto de retorno del esposo y desea el establecimiento de su vida en ese país, al contrario, en el deseo del esposo del retorno y su fuerte sentido de pertenencia a su lugar de origen se refleja su deseo de recuperar el dominio dentro de la familia al realizar su proyecto de retorno.

Una anécdota que me contó un ex-migrante que había vivido en California durante 20 años y regresó a Jalos para criar y educar a sus hijos en su tierra natal, ilustra muy bien que México es un espacio de reivindicación de la identidad masculina tradicional patriarcal y autoritaria para los migrantes masculinos en general. Un migrante mexicano discutió con su esposa y la golpeó cuando vivía en Estados Unidos. Como respuesta inmediata, ella llamó a una patrulla y los policías llegaron a casa y lo arrestaron. Después de salir de la cárcel, ese migrante pensaba cómo podría vengarse de ella por ese trato tan sin respeto al hombre y se le ocurrió una idea. Un día invitó a su esposa a ir a Tijuana para ver corridas de toros. Cruzaron la frontera y llegaron a Tijuana. De repente, el migrante la golpeó. Pero esta vez no hubo patrulla ni arresto, regresaron juntos a California. Después de esta venganza, cada vez que tenía una discusión con su esposa y estaba en una situación desventajosa, ese migrante la invitaba "cariñosamente" de nuevo a ir a Tijuana a ver corridas de toros. 
El ex migrante que contó esta anécdota piensa que las mujeres deben de tener los mismos derechos que los hombres y la relación conyugal debe de ser equitativa, pero quiso explicarme con esta anécdota por qué los migrantes masculinos tienen el deseo del retorno y en cambio, sus esposas quieren el establecimiento en Estados Unidos y cómo se sienten avergonzados ante el empoderamiento de sus esposas dentro del hogar en Estados Unidos aquellos hombres que aún se aferran al machismo y a la idea de que el retorno a México es la única manera de recuperar su masculinidad.

En suma, en cierto modo, el deseo de retorno de los migrantes mexicanos masculinos es una nostalgia masculina en la que se refleja su deseo de recuperar la identidad de género tradicional patriarcal y autoritaria, y la tierra natal como el objeto de esta nostalgia es un espacio de empoderamiento masculino.

Se puede interpretar que la nostalgia masculina que surge del contraste entre las imágenes de la mujer en México y en Estados Unidos y de la diferencia en la relación de género entre dos países, también se refleja en la expectativa de los jóvenes migrantes masculinos de buscar novias al regresar a su tierra natal en temporada de fiestas locales. En la entrevista con un grupo de jóvenes migrantes solteros que trabajaban en California, me comentaron que ellos querían casarse con mujeres de Jalos de "allá" (México) porque pensaban que las mujeres de Jalos que crecieron en Estados Unidos tenían las ideas y los valores de ese país que ellos no necesariamente comparten, en cambio, las mujeres de Jalos nacidas y crecidas en su tierra natal eran más tranquilas y seguían más con la cultura de allá.

Esta nostalgia masculina hacia las mujeres de la tierra natal se puede ver en las imágenes de mujeres de Jalos que describen los escritores jalostotitlenses. Por ejemplo, en el libro titulado, En un Pueblo Alteño, publicado originalmente en 1966 y cuya nueva edición se publicó en 1976 por la colaboración del Club Social Jalostotitlán de Los Ángeles, Pedro Rodríguez Lomelí, originario de Jalostotitlán, presenta sus ensayos sobre la añoranza y los recuerdos de su infancia en su tierra natal. Describe la imagen de las mujeres de su región de origen del siguiente modo: 
Hermosas son las mujeres alteñas; hermosas y altas; hermosas y blancas [...] Su alma religiosa se manifiesta hasta en el amor [...] La novia alteña es firme en su cariño; nunca traiciona. Penas y sacrificios; trabajos y castigos, nada la hace desistir de aquel amor, ni mucho menos traicionarlo [...] Trabajadora, leal, honrada, honesta, religiosa, resignada, fiel hasta la exageración; he allí las características de las alteñas. $^{64}$

Asimismo, caracteriza a las esposas de la región de los Altos de Jalisco de la cual forma parte su tierra natal de la siguiente manera:

La esposa alteña es fiel, abnegada, sostén espiritual y colaboradora del esposo en todo [...] Son así la inmensa mayoría, podíamos decir la totalidad de las esposas y madres alteñas, que se convierten en un tesoro de fidelidad para el esposo; en una seguridad para su vida y tranquilidad, y en un ejemplo vivo de honestidad para los hijos. ${ }^{65}$

También personifica la tierra natal como madre en el poema dedicado a su tierra natal.

Las campanas de mi pueblo que alegres cantando están, parece que van diciendo:

Jalos...Jalostotitlán!

Son sones me dicen una muy dulce canción de cuna: es su sonido hay la santa placidez de una oración: es mi madre que me canta su dulce y vieja canción. ${ }^{66}$

César Ramírez Ramírez, compositor y pintor nacido y radicado en Jalostotitlán describe su tierra natal con la asociación de la imagen de mujeres.

Si las mujeres son flores, mi Jalos es un jardín, donde hay de todos colores, donde hay de todos colores, como se dan por aquí.

\footnotetext{
${ }^{64}$ Rodríguez Lomelí (1976: 25-29).

65 Rodríguez Lomelí (1976: 31).

${ }^{66}$ Poesía titulada “Las campanas de mi pueblo" (Rodríguez Lomelí, 1976).
} 
Hay morenas de ojos negros

güeras cual durazno prisco,

con los ojos más azules

con los ojos más azules,

que el cielo de mi Jalisco. ${ }^{67}$

Ay que bonitas si señor

son las gardenias,

ay que bonito es el tulipán

pero más lindas

son las Alteñas

que se dan en ésta tierra

que es mi Jalostotitlán. ${ }^{68}$

El historiador mexicano, Luis González y González, quien propuso la idea de la microhistoria, denomina a la comunidad local como objeto de descripción como la matria. Para él, la matria se refiere al "mundo pequeño, débil femenino, sentimental de la madre; es decir, la familia, el terruño, la llamada hasta ahora patria chica" (González y González, 1986: 15). Retomando lo que propone este historiador mexicano, sería adecuado llamar al terruño que añoran los migrantes jalostotitlenses matria. La matria de los migrantes es un espacio sagrado de ritual que gobierna la Virgen de la Asunción, la madre sagrada de los jalostotitlenses. Es un espacio imaginario e idealizado donde habitan las mujeres, madres y esposas que les permitan a los migrantes recuperar la identidad masculina tradicional.

\section{NOSTALGIA HACIA LA IDENTIDAD}

En las narrativas nostálgicas de los migrantes que hacen contraste entre su tierra natal y el lugar de residencia actual y entre el pasado y el presente, en ocasiones se comparan espacios y tiempos en términos de lo nuestro y lo ajeno, es decir, en términos del yo y el otro.

Por ejemplo, en la narrativa que hace contraste entre el terruño y la sociedad receptora en las relaciones familiares, la sociedad estadounidense donde los anglosajones por lo general tienen una vida solitaria y se alejan de sus familias se describen como espacio del otro, en contraste, se narra que los mexicanos dan

\footnotetext{
67 Poesía titulada “Jalos” (Ramírez Ramírez ,1998: 184, 185).

68 Poesía titulada “Jalos de agualcarna” (Ramírez Ramírez, 1998: 231,232).
} 
más importancia a los lazos familiares, extrañan a sus familias y añoran y regresan a la tierra natal donde se quedan sus familias.

Espinosa también presta atención a esta forma narrativa de los migrantes donde contrasta el lugar de origen en México con la vida en Estados Unidos, y señala el sentido de pertenencia que los migrantes mexicanos expresan en este tipo de narrativa. Al manifestar la nostalgia de su tierra natal, los migrantes mexicanos por lo general describen a Estados Unidos como "un mundo desolado, sin calor humano y un lugar donde llevaban una vida atrapada en la rutina del trabajo esclavizante", en contraste con esta imagen negativa de la sociedad receptora, su tierra natal "era descrita como un lugar donde reinaba la tranquilidad, la libertad y la facilidad de llevar una vida mucho más gregaria", y este espacio es la tierra a la que identifican sus sentimientos de pertenencia (Espinosa, 1998: 28).

Por el otro lado, como había mencionado en el apartado anterior, la comparación entre "aquí" y "allá" no sólo tiene el significado espacial, sino también temporal. Los migrantes añoran un Jalos de las épocas anteriores donde ellos pasaban su infancia y existían el paisaje rústico y el estilo tradicional del campo más que el Jalostotitlán actual, y sienten la pertenencia a este espacio del pasado.

No necesariamente es un rasgo peculiar del caso de los migrantes mexicanos la forma narrativa de la nostalgia a través de un ejercicio de comparación entre dos puntos, la idealización del pasado, el terruño y lo "propio" y la desvaloración del presente, el lugar de residencia actual y lo "ajeno". Sandra Lorenzano (2004), quien hizo un análisis literario de las obras de los escritores argentinos exiliados, señala que esta forma comparativa de narrar tanto la tierra extranjera como la tierra natal aparece en varias obras como un ejercicio para categorizar el tiempo, el espacio y las características del lugar y la época, definiendo cuáles elementos son lo "nuestro" y cuáles son lo "ajeno"

Sostiene que un "elemento que se repite en los textos literarios escritos en el exilio es la oposición entre un espacio de pertenencia y otro de ajenidad." El espacio de ajenidad "es el que recuerda permanentemente la extranjería; las marcas en el paisaje no convocan en principio ningún recuerdo, no hay huellas de una historia propia en el nuevo lugar". El "espacio de pertenencia es el lugar de la 
historia personal, el sitio de la memoria. Muchas veces ésta se transforma en un espacio mítico, idealizado por obra de la nostalgia y la añoranza" (Lorenzano, 2004: 255, 256).

Para los migrantes jalostotitlenses, el espacio de ajenidad, es el mundo caracterizado por el paisaje urbano y por el estilo de vida moderna, particularmente, se refiere a la sociedad en donde ellos se han asentado en Estados Unidos. Ahí sienten que están en el exterior del idioma, de los papeles sociales importantes que otorga el estado-nación a los ciudadanos, de la historia nacional y de la identidad nacional que los discursos hegemónicos definen, debido a su condición de trabajadores extranjeros de un grupo étnico minoritario.

En el libro publicado por don Severiano Jáuregui Pérez, expresa que los migrantes mexicanos han sentido rechazos sociales y políticos y sus esfuerzos han sido subestimados dentro de la sociedad estadounidense. Uno de los objetivos principales de su libro consiste principalmente en que a través de la presentación de las entrevistas con los migrantes mexicanos destacables, principalmente los migrantes jalostotitlenses, que demostraron sus logros económicos e intelectuales, intenta exigir a la sociedad estadounidense el reconocimiento social y político de la existencia de los migrantes y la integración social más justa de esta población en la sociedad receptora.

aclaramos a nuestros adversarios potenciales, a los que afirman que nosotros, los latinos somos la rémora del progreso de esta nación, somos los únicos causantes de todo lo que distorsiona en esta sociedad; a ellos les respondemos que están rotundamente equivocados [...]

A ellos, a nuestros adversarios, a los que no nos aceptan, a los que no están de acuerdo con nuestra presencia aquí; les recordamos que nosotros, como ustedes estamos cooperando al crecimiento, en todos los aspectos, de esta nación, a la que ya amamos con todas nuestras fuerzas.

A los gobernantes queremos comunicarles que ya no somos un puño. Las estadísticas dan indicios de que hemos crecido, en número, excesivamente, en contra del propio consentimiento de muchos de ellos [...]

Aquí muchos de nuestros antepasados, sentaron las bases de una economía saludable, vigorosa y creciente.

Aquí, en estas tierras, muchos de nuestros padres dieron rienda suelta a su energía.

Aquí, muchos de nosotros hemos trabajado, nos hemos sacrificado, hemos puesto nuestro mejor esfuerzo y toda nuestra capacidad [...] 
Nuestra intención es actuar de acuerdo a nuestros merecimientos. Damos en primer lugar las gracias, a toda la nación, porque ha tolerado nuestra presencia. Pero exigimos que lo que antes fue tolerancia, por conveniencia de ustedes mismos, ahora por justicia, se convierta en reconocimiento a nuestros méritos [...]

Nuestro intención fue: que la historia de los inmigrantes pueda ser conocida, por igual, dentro y fuera de los límites de esta nación; por los hombres de estado y por los hombres de la calle igualmente; por los estudiosos y por los ignorantes; por ésa masa de gente acostumbrada a juzgar las cosas superficialmente, de acuerdo a lo que ven en las pantallas cinematográficas, sin el menor esfuerzo de su parte. ${ }^{69}$

De este modo, el autor manifiesta que los migrantes mexicanos no han podido obtener, de manera justa, el suficiente reconocimiento social y político por parte de la sociedad estadounidense a pesar de su creciente presencia en ese país, y a pesar de que han contribuido de una manera importante al crecimiento de la economía nacional (Jáuregui Pérez, 1981). Estados Unidos es un espacio de ajenidad no sólo porque ellos no pueden identificar sus sentimientos de pertenencia con los otros que habitan la sociedad receptora, sino porque ellos mismos son "otros", aquellos que son subalternos y están alienados dentro de la sociedad estadounidense.

Por otro lado, muchos de los migrantes jalostotitlenses no pueden identificar el sentido de pertenencia en la sociedad receptora, por otras razones, como la religiosa, de género, generacional, social y cultural. Por ejemplo, al enfrentarse con la imposibilidad de estar en su terruño en temporada de fiestas locales, la sociedad receptora aparece como un espacio de ajenidad porque ahí no pueden participar en los rituales, hacer reencuentro con sus familias y reforzar la identidad religiosa y social como en Jalostotitlán. Para algunos migrantes masculinos, Estados Unidos es un espacio de ajenidad porque ahí la masculinidad tradicional con la que se identifican tiene un significado negativo y es objeto de crítica social ante el empoderamiento femenino en el lado norte de la frontera, y se encuentran lejos de la sociedad donde se acepta esta identidad masculina tradicional. Asimismo, para los migrantes jubilados, Estados Unidos es un espacio de ajenidad donde pasan su vejez solitaria sin recibir algún papel social con el que se identifican.

69 Jáuregui Pérez (1981: 8, 9, 11). 
En contraste, el espacio de pertenencia de los migrantes jalostotitlenses es un lugar donde quedan los recuerdos de su infancia y juventud; un Jalostotitlán como espacio rural anterior a la urbanización; es un lugar donde gozan de la libertad alejándose de la cotidianeidad sujeta a la rutina del trabajo, la soledad y las estrictas normas sociales de Estados Unidos; es una tierra que habitan las mujeres bellas que siguen con la relación de género tradicional, las madres y esposas que se dedican a cuidar el hogar y los vecinos que se conocen entre sí y sus familias y saben quiénes son; es un lugar sagrado donde los valores religiosos gobiernan el tiempo, el espacio y los comportamientos de los habitantes; es un pueblo rural donde aún quedan el paisaje del campo y el estilo de vida tradicional donde hay respeto a los mayores y actividades sociales para los ancianos; es un lugar donde ellos pueden sentir el cambio temporal en estatus social; es un lugar donde pueden olvidarse de la soledad y sentirse como la mayoría al compartir la identidad local con los habitantes de su tierra natal.

En suma, el anhelo y el apego por la tierra natal que se expresan a partir del contraste entre el espacio de ajenidad y el espacio de pertenencia es un reflejo del deseo de los migrantes de buscar y representar la identidad. En esta narrativa nostálgica, ellos no construyen y representan su identidad a partir de un "aquí", "ahora" o futuro, sino desde una "allá", es decir, desde la tierra natal y su pasado que dejaron en el lado sur de la frontera.

\section{CONCLUSIONES: NOSTALGIA, DISTANCIA Y ALIENACIÓN}

En este capítulo analicé distintas formas narrativas de la nostalgia de los jalostotitlenses que han dejado su terruño en diferentes períodos históricos desde principios del siglo XX. Lo que explica la tipología de la nostalgia que planteé en los apartados anteriores es una diversidad en la forma de "distanciarse" del terruño.

Por lo general, la nostalgia se entiende como un estado de ánimo que nace en el individuo cuando se separa físicamente del lugar en donde nació, creció y se acostumbró a vivir y no puede adaptarse al nuevo ambiente del lugar de destino. Sin embargo, la tipología de la nostalgia demuestra que este sentimiento no surge 
simplemente del sentido de distancia física que experimenta el sujeto desplazado entre el punto de partida de su viaje y el lugar de destino, sino de las experiencias personales y los factores sociales y culturales que acompañan al viaje. Al tener las "experiencias amargas" en el lugar de destino de su viaje, como, el fracaso, la soledad, la tristeza, el dolor, el sujeto siente el contraste entre el terruño donde vivió antes y el lugar donde se encuentra actualmente y entre su pasado y su vida presente, y dirige la añoranza hacia los primeros términos. En este sentido, el sujeto nostálgico no está distante de su lugar de origen sólo espacialmente, sino también temporalmente.

No obstante, el contraste que siente no se marca de una manera abstracta entre el terruño y el lugar de destino y entre el pasado y el presente, sino entre los aspectos detallados de la vida humana, como las formas de relaciones sociales, el modo de vida, prácticas culturales, costumbres, tradiciones, instituciones, el paisaje, relaciones de género y generacionales y la identidad.

Asimismo, las "experiencias amargas" no siempre son meramente personales. Más bien, algunas experiencias personales negativas están determinadas por el contexto social y cultural que el individuo vivió antes en su terruño o vive actualmente en el lugar de destino. Por ejemplo, en el caso de los migrantes jalostotitlenses, una de las causas principales de la experiencia de distanciarse del terruño que despierta en muchos de ellos la nostalgia es la situación que dificulta a los migrantes sincronizar el viaje de retorno temporal con el calendario ritual de su lugar de origen. Para aquellos migrantes que nacieron y crecieron en el contexto social y cultural del terruño donde las fiestas locales tienen un significado importante para los habitantes y que han encontrado en ellas otros significados importantes durante su estancia en Estados Unidos, las temporadas de las fiestas locales son períodos del año en que sienten el mayor sentido de distancia cuando no pueden regresar a su terruño.

Sin embargo, lo que se espera del lugar de origen no es compartido de manera homogénea por los migrantes jalostotitlenses, sino que varía en términos generacionales y de género. Para los jóvenes, el terruño es un "espacio de libertad" donde ellos pueden liberarse de la cotidianeidad sujeta a la rutina del 
trabajo y la soledad; es un lugar donde pueden olvidarse de su condición de ser trabajadores migrantes subalternos dentro de la sociedad receptora; es un lugar importante para buscar novias y para avanzar hacia la siguiente etapa del ciclo de vida. Para los migrantes jubilados, Jalostotitlán es la tierra en donde pueden encontrar más papeles y oportunidades en la participación social así como ser más valorados socialmente que en Estados Unidos. Para los migrantes masculinos en general, el terruño aparece como un lugar que habitan las mujeres que aceptan la identidad masculina tradicional. Asimismo, el sentido de distancia entre dos lugares también se percibe a través de la oposición entre el "yo" y el "otro". El terruño es visto como un espacio donde los migrantes pueden identificar el sentido de pertenencia y se distingue de la sociedad receptora como espacio de ajenidad. En pocas palabras, en el sentido de distancia entre el terruño y el lugar de destino que experimentan los migrantes están enredados estos factores sociales y culturales.

Lo que quiero destacar en la tipología de la nostalgia que explica distintas formas de distanciarse del terruño es que estos sentidos de distancia no son simplemente productos de las experiencias de separación espacial, temporal, social y cultural del lugar de origen. Más bien, son sentimientos de insatisfacción provocados por las experiencias de "alienación". En otras palabras, otro aspecto importante que revela la tipología de la nostalgia jalostotitlense es el contexto en que surgen distintas experiencias de "alienación".

No uso la palabra alienación en el sentido psiquiátrico, es decir, el término genérico que comprende todos los trastornos intelectuales. No pretendo entender de nuevo la nostalgia como una "enfermedad". Más bien, sería mejor explicar el significado que doy a esta palabra, revisando el significado del uso común de este vocablo. Por lo general, entendemos como "alienación" la condición en la cual el individuo cae al estar insatisfecho con lo que es y al sentir la contradicción entre su ideal y la realidad.

Hegel fue quien usó originalmente este término como un concepto analítico para entender la vida humana. ${ }^{70}$ Sostiene que la vida humana consiste en realizar

${ }^{70}$ Georg Wilhelm Fredrich Hegel, 1999, Fenomenología del espíritu. Madrid, Fondo de 
el ideal que el individuo describe en su mente; pero él se enfrenta con la contradicción entre su ideal y la realidad. Esta contradicción es a lo que se refiere el concepto de alienación de Hegel.

Posteriormente, Marx convirtió este concepto en un término económico. En Manuscritos económicos y filosóficos que publicó Marx en 1844, desarrolló su teoría de alienación. ${ }^{71}$ Su idea parte de la siguiente idea de Hegel sobre el trabajo: el trabajo se caracteriza originalmente como un acto de autorrealización porque al trabajar, el individuo expresa su esencia e inscribe su espíritu en el objeto de trabajo. Retomando esta idea, Marx plantea que el trabajo, es decir, la "producción" era originalmente un acto de invertir la fuerza de trabajo en los medios de producción para generar los productos que el individuo iba a recibir como beneficios de su propia fuerza de trabajo.

Sin embargo, según Marx, en la sociedad capitalista este esquema ideal de trabajo-autorrealización se desploma y el trabajo que debería de permitir la autorrealización se convierte en lo que aliena al individuo en varias formas. En la sociedad capitalista, los trabajadores no pueden obtener los productos generados por sus propias fuerzas de trabajo. Por mucho que produzcan las mercancías, quienes las obtienen no son ellos, sino los capitalistas. Además, lo que producen los trabajadores genera el capital que ejerce el dominio sobre ellos porque en el capitalismo ellos son aquellos que ofrecen fuerzas de trabajo y reciben el sueldo equivalente a ellas.

Pero, los trabajadores no están alienados solamente de los productos, sino también del trabajo que originalmente era un acto que les permitía la autorrealización. En la sociedad capitalista los trabajadores son fuerzas de trabajo, por lo tanto, son "mercancías" y propiedad de los capitalistas. En esta situación, los trabajadores no pueden sentir la satisfacción con el trabajo porque ahora el trabajo ya no es un acto que nazca de su propia iniciativa y que satisfaga su deseo de autorrealización, sino un acto forzado y un medio necesario para poder realizar su deseo fuera del trabajo. En pocas palabras, en el capitalismo los trabajadores

\footnotetext{
Cultura Económica.

${ }^{71}$ Karl Marx, 1976, Manuscritos económicos y filosóficos de 1844, México, Cultura popular.
} 
tienen que buscar autorrealización fuera del trabajo y no pueden encontrar a un yo original en el trabajo.

Además, estas formas de alienación obstaculizan a los individuos el tener actividades humanas creativas, les privan de la esencia de la vida humana y les hacen caer en condiciones antihumanas. A diferencia de Hegel, quien sostenía hacer un cambio en espíritu para resolver la contradicción entre el ideal y la realidad, Marx buscó la forma para anular la alienación en la transformación de la realidad misma, la realidad de la sociedad capitalista.

Es cierto que este argumento de Marx sobre el trabajo y la alienación es un modelo teórico extremo, y por lo tanto, cabe añadir críticas y modificaciones. Sin embargo, este argumento nos da algunas pistas para entender cómo se han convertido en seres alienados los jalostotitlenses que dejaron su terruño y cruzaron la frontera para insertarse en el mercado laboral de Estados Unidos y cómo experimentan la contradicción entre su ideal y la realidad al quedarse en ese país como migrantes laborales.

Muchos de los jalostotitlenses que tenían aspiración o necesidad de buscar mejores oportunidades económicas que en su tierra natal encontraron el camino del "progreso" en Estados Unidos y dejaron Jalostotitlán para viajar hacia el Norte. En este proceso migratorio internacional, ellos fueron introducidos en la economía estadounidense como mano de obra barata y se convirtieron en trabajadores para generar productos por medio de su fuerza de trabajo para los otros. Sin embargo, debido a sus condiciones de trabajar para los patrones estadounidenses y las características del trabajo con operaciones simples y repetitivas, para ellos el trabajo aparece como una actividad rutinaria a través la cual no puedan buscar autorrealización. $^{72}$

${ }^{72}$ Como explicaré en el capítulo 3, la mayoría de los jalostotitlenses habían vivido tradicionalmente en ranchos y se habían dedicados a la producción agrícola y ganadera. Cuando comenzó el auge de la migración hacia Estados Unidos, el rancho era visto como un espacio de atraso, en cambio, el Norte era como un espacio de progreso. Sin embargo, en el proceso migratorio los migrantes han desplazado el significado del campo y del Norte. Por ejemplo, al establecerse en Estados Unidos, la vida en el rancho ha sido vista como un estilo de vida independiente por los migrantes. Este cambio en la imagen del campo tiene que ver con las experiencias de alienación que viven los migrantes tanto en la vida social como en la vida laboral. 
Además, en la sociedad receptora, estos jalostotitlenses que fueron introducidos como mano de obra barata extranjera, no son solamente trabajadores que están sujetos al dominio del capital, sino también son uno de los grupos étnicos minoritarios en la sociedad estadounidense. Por sus condiciones de ser subalternos en términos sociales, económicos y políticos y ser vistos culturalmente como "otros", no han podido integrarse completamente en la sociedad receptora. En otras palabras, los migrantes han vivido las experiencias de alienación tanto del trabajo como de la sociedad receptora. Para ellos, la posibilidad de anular la alineación dentro de ese país no está tan abierta debido a sus condiciones de trabajadores migrantes extranjeros del grupo minoritario y a las normas estrictas de la sociedad receptora.

En este contexto, los migrantes han intentado buscar formas para anular las experiencias de alienación y realizar su deseo de autorrealización en el "exterior" del tiempo, el espacio y la realidad que viven como sujetos alienados. Este "exterior" en donde ellos esperan encontrar una vida auténtica y un yo ideal es su terruño que se encuentra en el exterior de Estados Unidos visto como espacio de trabajo; es el tiempo y el espacio ritual en donde se suspenden las normas, relaciones y posiciones sociales de la vida cotidiana en Estados Unidos; es el pasado que contrasta con la vida presente en ese país; es el terruño imaginario que se diferencia de la realidad actual con la que no pueden sentir satisfacción.

Sin embargo, aunque ellos han encontrado en su terruño formas para anular las experiencias de alienación en la sociedad receptora, no ha sido fácil realizar sus proyectos de retorno temporal. Cuando se enfrentan con las situaciones que les imposibilitan regresar a su lugar de origen, experimentan el mayor sentido de distancia con el terruño y la alienación por la pérdida de varias oportunidades importantes para ellos: pierden la oportunidad para reafirmar su identidad religiosa y social; la pérdida de oportunidades para compartir la alegría del reencuentro con sus seres queridos, fortalecer lazos con ellos; la pérdida de oportunidades para buscar novias, recuperar la masculinidad tradicional, transmitir tradiciones y costumbres a sus hijos nacidos y crecidos en Estados Unidos y reincorporarse socialmente a su terruño; no pueden tener oportunidades para sentir un cambio en 
su estatus y actividades sociales al liberarse de la soledad, las normas sociales estrictas y sus condiciones de ser subalternos en Estados Unidos.

Para aquellos migrantes que nacieron y crecieron dentro del contexto social y cultural del terruño, la pérdida de estas oportunidades es la alienación de costumbres, tradiciones, valores, instituciones, el ritual, las relaciones sociales y la identidad social, religiosa y de género de su lugar de origen, es decir, una serie de elementos culturales que definen modos de vida ideales y modelos del yo ideal. En pocas palabras, el sentido de distancia con su terruño que experimentan los migrantes en varias formas es en lo que se reflejan varias experiencias de alienación, y lo que revelan diversas narrativas de la nostalgia de los migrantes es su condición de ser un yo insatisfecho, alienado e incompleto, un yo culturalmente "fragmentado".

Entonces, ¿cómo intentan los migrantes jalostotitlenses llenar los huecos de su vida interior y reunir los fragmentos de su yo ideal para escapar de las experiencias de alienación? Lo que les permiten hacerlo son terruños imaginarios que describen en su mente con la nostalgia. Si el análisis de la nostalgia revela el contexto de las experiencias de alienación, lo que nos explican las imágenes del terruño son significados del lugar que anula la alienación. El terruño que ellos recuerdan e imaginan como objeto concreto de la nostalgia es el lugar en donde dejan de ser sujetos ajenos y distantes del yo ideal y pueden recuperar los fragmentos perdidos de una vida auténtica. Para ellos, es un lugar en donde pueden gozar de modos y estilos de vida ideales que se definen en los contextos sociales y culturales en que sitúa cada uno de ellos.

Por lo general, se piensa que el modo de comportamiento, de pensamiento y de vida en cada sociedad, los valores y las normas dominantes e ideales en cada sociedad, se transmiten a los nuevos miembros de la sociedad a través de la socialización desde la infancia hasta llegar a ser adultos. En el caso de los migrantes jalostotitlenses, ellos salieron de su terruño después o antes de terminar el proceso de socialización y entraron a un ambiente sociocultural que consiste en las normas sociales, los valores y el modo de vida diferentes de los que habían adquirido o estaban adquiriendo en su lugar de origen. En esta situación, al 
experimentar el contraste entre su lugar de origen y el lugar de destino y al sentir que los elementos culturales que habían adquirido en su terruño desde la infancia y su forma de ser son ajenos al contexto social y cultural del lugar de destino, se sienten alienados de su lugar propio y experimentan la nostalgia hacia su terruño. Por eso, los sujetos que tienen experiencias de alienación en Estados Unidos dirigen la añoranza hacia un Jalostotitlán de su infancia y su juventud y el paisaje, el estilo de vida, la identidad de género, costumbres y tradiciones y papeles sociales que existían de manera dominante en estas etapas del ciclo de vida en las que estaban en el proceso de socialización, revaloran lo que había antes e identifican en ese lugar tiempo-espacialmente distante el objeto de la nostalgia y las formas para solucionar la alienación.

Sin embargo, como lo demuestra la tipología de la nostalgia, la imagen del terruño que anula las experiencias de los migrantes de alienación y llenan los huecos del yo fragmentado, no se imagina ni se representa de una forma homogénea entre los migrantes. La razón por la cual no existe la única imagen ideal del terruño para todos los migrantes es que el contexto y el factor de la alienación y los componentes faltantes que el sujeto desea recuperar para reconstruir su yo ideal varían dependiendo del posicionamiento en que cada uno de los individuos se sitúan. A partir de las experiencias de alienación vividas en su posicionamiento y del contraste entre la vida presente en Estados Unidos y un terruño del pasado visto desde su posicionamiento, el sujeto describe en su mente la imagen del terruño espacio-temporalmente distante que puede llenar la insatisfacción con la vida presente en Estados Unidos.

Pero las imágenes del terruño que ellos imaginan y representan en distintas formas como "tierra prometida" para anular la alienación, no necesariamente corresponden a la realidad objetiva de su lugar de origen del pasado y del presente porque estas imágenes del terruño son producto de la selección y la restauración de las memorias fragmentadas sobre su tierra natal a través de la imaginación. En este sentido, son producto de la idealización y de los terruños imaginarios. 
Aunque el terruño que se reconstruye de este modo en la memoria y la imaginación pertenece, de cierto modo, a la ficción y es diferente de la realidad de Jalostotitlán, para los migrantes, es un lugar tan "real" y "verdadero" que les despierta el sentido de pertenencia. Para ellos, el terruño imaginario es un lugar que les hace olvidar y escapar de la realidad dura en Estados Unidos; es un lugar de consuelo, terapéutico y de esperanza para los sujetos alienados; es un terruño de ensueño o una "tierra prometida" donde existe un ambiente social y cultural que les permita llegar a obtener una identidad estable, un yo ideal. En este sentido, la nostalgia es el deseo de los sujetos alienados de transformarse en seres sociales diferentes de lo que son ahora y estar en un lugar distante que les posibilita esta transformación.

Sin embargo, como lo explicaré en los siguientes capítulos, la nostalgia no sólo es un sentimiento que les hace a los sujetos alienados construir las imágenes del terruño que flotan moviéndose entre la dimensión de imaginario y la de representación, sino que también aparece como una subjetividad que saliendo de estas dimensiones, influye sobre la realidad que viven los migrantes jalostotitlenses y los habitantes de su lugar de origen, y como el motor de la transformación de prácticas espaciales, temporales y culturales y actividades económicas entre los lugares de destino en Estados Unidos y el lugar de origen en México. 


\title{
Capítulo 3
}

\section{Campo y Ciudad: El surgimiento de las vacaciones de los migrantes y la nueva imagen del espacio rural}

\begin{abstract}
cuántas veces, allá en tierras lejanas, por las noches, mis párpados velaban el desfile de imágenes queridas...El camino que va del poblado al rancho, las cercas, los recuestos, los vados propicios para cruzar el río, los viejos sabinos bordeándolo y bebiendo frescura al hundir las raíces en su orilla...Las portillas de trancas que comunicaban los potreros... Con la ligereza de la imaginación, hacía el arribo a nuestra casa

(“Mi pueblo", Guadalupe Gutiérrez de Mantecón, 2003, La Querencia, pp.65-66)
\end{abstract}

\section{INTRODUCCIÓN}

En su libro titulado, La Querencia, Guadalupe Gutiérrez de Mantecón, quien nació en 1913 y pasó su infancia en un racho perteneciente al municipio de Jalostotitlán, pero que vivió en la Ciudad de México la mayor parte de su vida, narra sus recuerdos de la vida en el rancho y la convivencia con la naturaleza y la añoranza por el paisaje del campo y por el estilo de vida tradicional en el pueblo y en el rancho, y hace un retorno al pasado y a su tierra natal a través de la memoria y la imaginación desde su vida de vejez en la Ciudad de México. La añoranza por Jalostotitlán como espacio rural y el fuerte vínculo emocional con el paisaje del campo y el estilo de vida rural de su tierra natal no son algo particular de esta escritora. De hecho, muchos migrantes radicados en Estados Unidos que pasaron su infancia en algunos ranchos de Jalostotitlán comparten esta subjetividad hacia el espacio rural.

Un migrante jubilado de 74 años me invitó a pasar al jardín de su casa ubicada en Norwalk, el condado de Los Ángeles. ${ }^{73}$ Me enseñó la higuera, el manzano y cebollines que sembraba en su jardín. Desde que lo conocí en agosto de 2003 en Jalostotitlán, siempre me invitaba a ir al rancho de su familia. Me decía que ahí tenía un pedazo de terreno que heredó de su padre. Ahí se cultivaban

\footnotetext{
${ }^{73}$ En el otoño de 2004, realicé el trabajo de campo en California.
} 
maíz, alfalfa, chayote, etc. Aunque este pequeño terreno producía sólo alrededor de 7,000 pesos al año, tener un pequeño campo agrícola le daba mucha satisfacción porque "uno puede trabajar por sí mismo, no para algún patrón". Por eso, cultivaba varias plantas en el jardín de su casa en Estados Unidos.

El apego a la tierra, los recuerdos de la vida en el rancho y la añoranza por el paisaje del campo y el estilo de vida rural son una forma persistente y dominante entre muchos migrantes jubilados que radican en Estados Unidos y en otras ciudades de México para expresar su nostalgia hacia Jalostotitlán. En las entrevistas, ellos narraban que antes Jalos era un pueblo pequeño donde todos se conocían y que muchas familias vivían en los ranchos y se iban al pueblo los domingos para la misa, en cambio, la gente que vivía en el centro del pueblo iban a su rancho a trabajar diario e iban con su familia en vacaciones de escuelas de sus hijos.

En contraste con el paisaje rural que describen los migrantes con añoranza, ahora Jalostotitlán es una localidad que cuenta con más de 20,000 habitantes donde al parecer, el paisaje urbano predomina sobre la rusticidad que queda gravada en las memorias e imaginación de los migrantes que aún podían pasar una etapa de su vida en el Jalostotitlán del pasado cuando Jalos era un pueblo pequeño y había muchos ranchos a su alrededor. Algunos campos agrícolas de la cabecera municipal, donde pasaron su infancia, se han reducido y otros han desaparecido en el proceso de urbanización, construcción de viviendas y surgimiento de otros sectores laborales. El pueblo de Jalos que recuerdan muchos migrantes tampoco existe ahora. Jalos ya no es un pueblo donde todos se conocen cara a cara porque la población creció rápidamente y porque muchos de los vecinos que conocían se fueron a Estados Unidos y a otras ciudades de México y formaron familias en los lugares de destino. De hecho, en 1970 esta localidad subió oficialmente a la categoría de ciudad y desde los años setenta la tendencia a la concentración demográfica en el espacio urbano de Jalostotitlán venía acentuándose a pesar de que al mismo tiempo, la migración hacia Estados Unidos se había intensificado. 
Entonces, ¿el paisaje rural en el cual los migrantes identifican la nostalgia ha desaparecido por completo en su terruño como espacio físico? ¿Jalostotitlán como un pueblo rural y el estilo de vida rural existen sólo en memorias e imaginación de aquellas generaciones que vivieron allí antes de la transformación urbana de esta localidad? ¿Para los migrantes jalostotitlenses, el deseo del retorno al espacio rural de su terruño es un sueño que no se puede materializar en la vida real? ¿El terruño como espacio rural es un lugar que pertenece al pasado adonde pueden llegar los migrantes solamente "con la ligereza de la imaginación" como lo dice la autora de la prosa que presenté en el principio de este capítulo?

Sin embargo, desde que comenzó el retorno temporal masivo de los jalostotitlenses radicados en Estados Unidos en temporada de las fiestas locales en la segunda mitad de los años ochenta, otro proceso de transformación de Jalostotitlán inició. La llegada de un gran número de los ausentes a Jalostotitlán para asistir al carnaval y a las fiestas patronales de agosto ha levantado negocios que venden productos y servicios que representan signos del estilo de vida rural. En agosto, tanto los habitantes de la cabecera municipal como los ausentes que vienen de distintas ciudades de Estados Unidos y de México organizan convivencias familiares en suburbios de la cabecera municipal donde aún quedan los campos agrícolas a menor escala que en la época en que pasaron su infancia. Corridas de toros, charreadas, peleas de gallos y conciertos de música ranchera se organizan a mayor escala que en las décadas anteriores atrayendo a los habitantes y a miles de visitantes que llegan a Jalostotitlán para celebrar el carnaval. Además, en los años recientes, inició el proyecto local de conservación de viviendas de estilo arquitectónico rústico del centro de la ciudad. De este modo, el ambiente de un "pueblo rural" y el estilo de vida "ranchera" se reviven y se reestrena durante las fiestas locales, inscribiéndose las imágenes rústicas encima del Jalostotitlán urbanizado.

En este capítulo, pretendo entender el proceso reciente de reconstrucción de Jalostotitlán en que se reestrena el paisaje del "pueblo rural" en las escenas de las festividades locales, a partir de enfocarme en la articulación de los procesos migratorios y del retorno temporal masivo con este proceso local. Para ello, 
primero analizaré la formación de la nostalgia de los jalostotitlenses radicados en Estados Unidos hacia Jalostotitlán como espacio rural. Aquí, los términos "campo" y "ciudad" son claves para entender el contexto histórico, social y cultural de la construcción de este sentimiento.

Raymond Williams (1973) fue quien abrió el camino para estudiar el sentimiento como algo más que una simple experiencia personal e individual, es decir, analizar la construcción de la subjetividad desde una mirada sociológica e histórica. Descubrió el vínculo entre el sentimiento y los cambios en el entorno social que rodea al sujeto. Al revisar varios textos de la literatura inglesa cuyo tema es el campo y la ciudad, Williams encontró una tendencia permanente: los autores de diferentes épocas añoraban los campos y se lamentaban de los cambios en el paisaje y la vida rural. Williams propone dos razones de esta persistente nostalgia hacia el campo. En primer lugar, los campos que los autores añoraban fueron las localidades en donde ellos pasaron su niñez. La memoria de la niñez tiene algún significado permanente. Williams expresa este tipo de sentimiento permanente y persistente con el término de estructura de sentimiento. Esta estructura de sentimiento de la memoria de la niñez evoca en los autores las imágenes idealizadas del pasado del campo. En segundo lugar, sostiene que la idealización del campo y la desvaloración de la ciudad que hacen los autores son una manera de percibir y reaccionar a los cambios en su entorno social.

Siguiendo esta propuesta de Williams, en los primeros tres apartados de este capítulo, exploraré los cambios en el entorno social donde han vivido los migrantes jalostotitlenses, para entender el surgimiento de la estructura de sentimiento hacia el espacio rural de su terruño. En el primer apartado, analizaré el proceso de transición del campo a la ciudad en Jalostotitlán desde principios del siglo XX hasta el presente. Pero, en vez de analizarlos solamente dentro del contexto local, pretendo hacerlo enfocándome en la articulación de los procesos migratorios con este proceso local.

Sin embargo, para entender la formación de la nostalgia de aquellos sujetos que han vivido los cambios en su entorno social que se extiende más allá del contexto local, no es suficiente analizar el proceso local de su terruño. Por eso, en 
el segundo apartado, exploraré el proceso de transición del campo a la ciudad en los lugares de destino de los migrantes en el sur de California. En el caso de la migración jalostotitlense hacia Estados Unidos, los patrones migratorios que tradicionalmente se caracterizaban por la movilidad hacia las zonas agrícolas en la sociedad receptora, se han cambiado desde hace cuatro o cinco décadas por el trabajo y residencia en las zonas urbanas. En este proceso de transición del campo a la ciudad que se dio en California, la sociedad estadounidense en la cual proyectaban los migrantes el "sueño americano" se ha interpretado de manera negativa por ellos, en cambio, los campos del terruño que habían sido vistos como "espacio de atraso" por los migrantes antes de cruzar la frontera, han adquirido un nuevo significado positivo y se ha convertido en el objeto de la nostalgia.

Pero, como explicaré en el tercer apartado, lo que surgió en este proceso de transición del campo a la ciudad en California, no sólo fue el "desplazamiento" del sentimiento y el significado del lugar de origen y el lugar de destino, sino también nuevas prácticas temporales y espaciales de los migrantes, es decir, el retorno temporal masivo que se da en las vacaciones de los migrantes. Esta corriente de los jalostotitlenses que se dirige al sentido contrario de la migración laboral internacional y opuesta a la lógica del trabajo ha creado el contexto en que Jalostotitlán se imagina como espacio rural lúdico a partir del vínculo con el tiempo de ocio. Además, a través de esta nueva práctica espacial de los migrantes en sus vacaciones, ha surgido el contexto en que el terruño como espacio físico hace el contacto con los terruños imaginarios colectivos de los migrantes y entra en un nuevo proceso de transformación local.

En el cuarto apartado, analizaré este nuevo proceso de transformación de Jalostotitlán que se basa en la materialización del nuevo imaginario colectivo sobre el espacio rural en Jalostotitlán. Para entender este proceso, el concepto de "simulacro" de Baudrillard (1978) y el de "hiperrealidad" de Eco (1999) son herramientas analíticas más útiles que la propuesta de Williams, porque lo que permite explicar la idea de Williams no es cómo los sentimientos cambian la realidad, sino cómo los cambios en la realidad operan sobre la formación de los sentimientos y porque las discusiones de Baudrillard y Eco pretenden 
precisamente explicar cómo el imaginario y los símbolos operan sobre la realidad del espacio físico. ${ }^{74}$ En el caso del nuevo proceso de transformación de Jalostotitlán, se materializa en el terruño que existe realmente el imaginario sobre su terruño como "pueblo rural" que los migrantes describen en sus memorias e imaginación.

En el último apartado, sintetizaré las implicaciones que se pueden sacar de los procesos que se presentan en este capítulo, enfocándome en la articulación de estos procesos que se han dado en ambos lados de la frontera entre México y Estados Unidos y en el papel que juega la nostalgia de los migrantes hacia el espacio rural en la transformación de su lugar de origen.

\section{DEL CAMPO A LA CIUDAD EN JALOSTOTITLÁN}

Después de la fundación del pueblo llamado El Divino Salvador de Xalostotitlán a mediados del siglo XVI en el proceso de la evangelización en los Altos de Jalisco, los españoles comenzaron a llegar a Jalostotitlán. La llegada de los colonos españoles tuvo que ver con el hecho de que a partir de la segunda mitad del siglo XVI, Jalostotitlán se había convertido en un lugar importante en la región de los Altos de Jalisco por dos razones: en primer lugar, porque se fundó en Jalostotitlán una parroquia cuyo curato abarcaba varias poblaciones de su alrededor; ${ }^{75}$ en segundo lugar, se habían desarrollado las rutas de comunicación con Guadalajara, Zacatecas y México alrededor de Jalostotitlán. A raíz del descubrimiento de las minas de Zacatecas en 1546, aumentó el tráfico entre México, Guadalajara y Zacatecas y creció la demanda de crear rutas transitables para hacer llegar alimentos y mano de obra y para el transporte de los minerales. ${ }^{76}$ En este contexto, los Altos de Jalisco se fundaron como un área de producción agrícola que abastecía de alimentos las zonas mineras, zonas de flujos de

\footnotetext{
${ }^{74}$ Véase el apartado de "Metodología ó ¡Sigue la imagen! del capítulo 1 de esta tesis.

${ }^{75}$ La parroquia de Jalostotitlán era una de las más importante y más ricas de la diócesis hasta que ocurrió un milagro en 1630 en una pequeña aldea de indios de San Juan Bautista Mezquitic (actual San Juan de los Lagos) que era dependiente del curato de Jalostotitlán. El curato del pueblo San Salvador de Xalostotitlán se componían de San Gaspar, San Miguel, Teocaltitán, Mitin, Temacapulín, Mezquitic, San Juan de los Lagos, las Haciendas de la Venta de Pegueros, la Venta, San José de los Reynoso y Cañada (Gutiérrez Gutiérrez 1985: 125).

${ }^{76}$ Gutiérrez Gutiérrez (1985: 123, 129, 130)
} 
productos y mercancía; y como punto de comunicación entre las minas y las ciudades. ${ }^{77}$

Al principio, las tierras eran propiedad de la corona. Pero los colonos españoles pudieron recibirlas al solicitar al rey la tenencia de las tierras como remuneración por los servicios prestados durante la conquista o al solicitársela pagando cierta cantidad de dinero. ${ }^{78}$ De este modo, los españoles ocuparon las tierras e introdujeron la ganadería y comenzaron a establecerse separados de los indios formando propiedades privadas, como haciendas y ranchos que tenían cierta autonomía política. Se repartían las tierras entre los herederos, de tal manera que se conservaban el patrimonio y la unidad dentro de las familias. Cabe destacar que el crecimiento del número de los poblados españoles fue rápido debido a que muchos españoles llegaron trayendo a sus familias a la Nueva España. Los españoles se establecieron principalmente en haciendas y ranchos y los indios centraron su vida en los barrios del pueblo. De este modo, se formó una sociedad ranchera dominantemente criolla aunque hubo mestizaje entre españoles y nativos. ${ }^{79}$

Durante la época colonial, los ranchos eran unidades sociales multifuncionales: Eran unidades tanto para colonizar las tierras conquistadas y defender los territorios de los ataques de los indios como para construir la base de la sociedad a través de la reproducción, la agricultura y la ganadería. Además, funcionaban como bases de abastecimiento de alimentos para las zonas mineras y como centro de producción de caballos que eran el principal medio de transporte para la comunicación con otros lugares y para el comercio. Además, el rancho era un elemento fundamental para la formación histórica de una identidad regional asociada con la vida autónoma y la convivencia con la naturaleza y ganados. ${ }^{80} \mathrm{En}$ su libro sobre la historia local de Jalostotitlán, José Antonio Gutiérrez Gutiérrez, historiador originario de esta localidad, explica la imagen del campo como un

\footnotetext{
${ }^{77}$ Fábregas (1986: 79, 80).

78 Gutiérrez Gutiérrez (1985: 156).

${ }^{79}$ Gutiérrez Gutiérrez (1985: 120, 138, 139).

${ }^{80}$ Gutiérrez Gutiérrez (1985: 144, 145).
} 
espacio sociocultural en los Altos de Jalisco en la época colonial del siguiente modo:

el mundo del hombre a caballo en la región alteña era el de charro, vaqueros, caporales, rodeos, coleadores, jaripeos, corridas de toros, canciones, machismo en el carácter, bebidas fuertes, gallardía en el montar, pasión en el amor, rudeza campesina, peleas de gallos, relucientes estribos, bellas monturas, grandes espuelas, anchos sombreros...

La general libertad y común estimación de la tierra es donde generan algunos aspectos de su personalidad. Parece pertenecer a una nación diferente, a un mundo aparte que aman por encima de todo "su" país, su cielo azul, su clima encantador y la belleza de sus mujeres; que cantan y pregonan de "lo suyo". "El habitante de la región [...] se siente frecuentemente en el pasado, orgulloso de su tierra, de su historia, de sus tradiciones y de esa honda personalidad autárquica que se fue fraguando a lo largo del lento proceso de colonización de 'su' territorio [...]"\$1

En este análisis histórico el mundo rural alteño de la época colonial se describe con la asociación de la vida autónoma e independiente, la libertad, machismo, mujeres, canciones, consumo de bebidas alcohólicas y algunas prácticas sociales y culturales del manejo de cierto ganado, y que la tierra, el pasado, tradiciones y ganado eran elementos importantes para la formación de la identidad regional.

En la época colonial, Jalostotitlán creció en cuanto a su demografía. Al principio del siglo XVII, se estima que Jalos contaba con aproximadamente 500 habitantes. En 1764 se realizó un censo general de la feligresía. Aunque sólo se contó el número de los adultos, el pueblo de Jalostotitlán tenía 211 familias establecidas y 1141 habitantes. La totalidad del número de habitantes de haciendas y ranchos era 10,557, un número mayor que el de cualquier pueblo de la jurisdicción. En 1765, se realizó otro censo que contaba 1296 habitantes del pueblo de Jalostotitlán incluyendo a los niños. En los ranchos y haciendas vivían 11,220 personas. El número de la totalidad de la población de su jurisdicción era

${ }^{81}$ Gutiérrez Gutiérrez (1985: 144, 145). 
$17,109 .{ }^{82}$ En la época de la Independencia, Jalostotitlán contaba 2,000 habitantes en la cabecera y 16,000 en su jurisdicción. ${ }^{83}$

A finales del siglo XIX, la municipalidad de Jalostotitlán contaba con 20,621 habitantes, 11,501 hombres y 9,120 mujeres. Aunque el número de la población en el pueblo de Jalostotitlán aumentó teniendo 5,485 habitantes, igual que las épocas anteriores, la mayor parte de los habitantes vivían en los ranchos y en las haciendas. ${ }^{84}$ En el año 1900, según el censo levantado por la parroquia de Jalostotitlán, la totalidad de los habitantes alcanzaba $23,036 .{ }^{85}$

Entrando a la segunda década del siglo XX, sucedió un acontecimiento importante que rompió esta tendencia de la mayor distribución demográfica en el campo en Jalostotitlán. En 1926 estalló la guerra cristera (1926-1929) como respuesta por parte de los católicos al gobierno anticlerical de Calles. Una de las medidas que el gobierno federal adoptó para controlar la rebelión en los Altos de Jalisco fue obligar a todos los habitantes de los ranchos a concentrarse en las cabeceras municipales para aislar a los cristeros que sostenían una guerra de guerrillas gracias al apoyo que recibían de los rancheros.

Cabe mencionar que más de 70 por ciento de la población de la región vivía en el campo. Por tanto, la concentración de todos los campesinos en el centro de cada pueblo causó la incertidumbre y el hambre porque el campo fue abandonado debido al traslado de los habitantes de los ranchos al pueblo y al alistamiento de los campesinos al movimiento cristero y porque los pueblos no contaban con suficientes alojamientos. El pueblo de Jalostotitlán recibió la llegada de más de 800 familias. Entonces, el "pueblo apenas contaba con lo necesario para 3,500

${ }^{82}$ En el período en que se realizaron estos dos censos, en la jurisdicción de Jalostotitlán se incluían Jalostotitlán, San Juan de los Lagos, San Miguel el Alto, Santiago de Teocaltitán, Pueblo de San Gaspar, Mezquitic, Pueblo de Mitic y haciendas y ranchos (Gutiérrez Gutiérrez 1985: 162, 163).

${ }^{83}$ Gutiérrez Gutiérrez (1985: 135; 162, 163, 173).

84 Juan Macías Gutiérrez, Cuadro estadístico de la municipalidad de Jalostotitlán 1880, México, Amigos de la historia de los Altos de Jalisco, AC., 1996

${ }^{85}$ La parroquia se constituía por Jalostotitlán, los pueblos de Cañadas, Valle de Guadalupe, Tamacapulín, San Gaspar, Teocaltitán, Mitin, La llave, Labor de San Antonio (Gutiérrez Gutiérrez 1985: 227). 
habitantes y al verse incrementados por esas 800 familias, tuvo que sufrir grandes estrecheces". ${ }^{86}$

A pesar de que regresaron al campo los campesinos que fueron concentrados en el pueblo de Jalostotitlán y las familias que se fueron a otros lugares después de este conflicto, se volvió inestable la economía de Jalostotitlán basada en la producción agrícola y ganadera. Los hacendados abandonaron sus tierras, en cambio, aumentó el número de pequeños propietarios de la tierra. Pero, en la sociedad agricultora y ganadera de Jalostotitlán se presentaban los factores no favorables para muchos de estos rancheros, tales como, el descuido del campo durante el movimiento cristero, la depresión económica mundial, la amenaza de la reforma agraria, la inserción de la región en el mercado más amplio. El clima de la región, la tierra "flaca" de Jalostotitlán, el tamaño reducido de sus tierras y escasos recursos económicos y tecnológicos no les permitían a muchos de los rancheros buscar una forma competitiva y eficiente de producción agrícola y ganadera que pudiera mantener a las familias con numerosos hijos. Ante esta difícil situación en el campo, los rancheros buscaron asentarse en el pueblo o emigrar a Estados Unidos, el país del norte adonde Jalostotitlán había enviado a sus habitantes desde principios del siglo $X X{ }^{87}$

José Antonio Gutiérrez Gutiérrez señala que en este contexto surgió una nueva ideología entre los rancheros. La explica de la siguiente manera:

es innegable la nueva orientación de los valores del ranchero, que ha cambiado el campo por la ciudad y que quiere que sus hijos no se dediquen directamente a las

${ }^{86}$ Gutiérrez Gutiérrez (1985: 253). Este número de 3500 habitantes es menor de lo que el pueblo de Jalostotitlán tenía a finales del siglo XIX. Una razón de esta reducción de la población que se puede suponer es que muchas familias decidieron abandonar su tierra natal por la inseguridad política y social causada durante la revolución y la guerra cristera.

${ }^{87}$ Gutiérrez Gutiérrez (1985: 261, 265-273). El clima del municipio es semiseco. La temporada de lluvia es junio y julio. Los suelos dominantes son del tipo planosol eútrico y feozen háplico. La explotación extensiva de las tierras para la ganadería y agricultura tiene un "techo demográfico" difícil de modificar sin innovaciones tecnológicas mayores. A diferencia del centro del país donde se buscó una solución de este tipo de problema a través de la intensificación del trabajo agrícola, en Los Altos de Jalisco había la dificultad de actualización de la producción agrícola. En este contexto, la migración ha sido una "válvula de escape" cuando la producción en el campo no ha podido responder al crecimiento demográfico (González de la Rocha y Escobar Latapí, 1990: 520). 
labores del campo. De este estrato social salen los comerciantes y los que emigran en busca de un mejor nivel de vida y de estudios.

La familia no espera ya que los hijos se dediquen al rancho tradicionalmente, a sembrar la tierra, a tener animales; lo que desea es que éstos estudien o que al ir a los Estados Unidos reúnan un capital suficiente para levantar una empresa por sí solos. El patrimonio de la familia ya no es el rancho; éste pertenece al padre quien sigue deseando que sus hijos se hagan de otro igual o mejor. ${ }^{88}$

En este período del siglo XX, ante la difícil situación para la producción agrícola y ganadera en el campo, el rancho se apropió de un nuevo significado, pero mucho más negativo de lo que representaba la imagen del rancho en la época colonial. El campo fue considerado como un espacio de estancamiento económico y como objeto de abandono. En cambio, la ciudad surgió como un nuevo espacio que se valoraba más, como un espacio de progreso y como un destino adonde los hijos de los rancheros deberían de llegar después de abandonar el campo.

La tendencia al abandono del campo tanto para la residencia como para el trabajo iba creciendo década tras década. El cuadro 1 demuestra el incremento notorio en la población del pueblo de Jalostotitlán donde actualmente se encuentra la cabecera municipal (aunque la extensión territorial de la jurisdicción de Jalostotitlán de la época colonial es diferente de la actual extensión territorial del municipio y que las fuentes de datos son diferentes). En la década de los años veinte del siglo pasado, la cabecera municipal contaba con 3,500 habitantes antes de la concentración de los campesinos en el centro del municipio sucedida en la guerra cristera. Sin embargo, medio siglo después, hubo un aumento de aproximadamente 10,000 personas en la cabecera municipal. De hecho, 66.16 por ciento de la población del municipio vivía en la localidad de Jalostotitlán.

Este incremento de la población en la cabecera municipal no se debe interpretar como producto de la gran afluencia de las personas desde el exterior del municipio a la cabecera municipal, sino como producto del movimiento poblacional hacia la localidad de Jalostotitlán dentro del municipio que contribuyó a este cambio demográfico, dado que la población total del municipio entre 1940 y

${ }^{88}$ Gutiérrez Gutiérrez (1985: 271). 
1980 (con la excepción de 1960) era menor al número de habitantes en el municipio en $1900 .^{89}$

\begin{tabular}{|l|l|l|}
\hline Año & Población de la jurisdicción total de Jalostotitlán & $\begin{array}{l}\text { Población } \\
\text { del pueblo o } \\
\text { la localidad } \\
\text { Jalostotitlán }\end{array}$ \\
\hline Siglo XVII & & 500 \\
\hline 1764 & 15,376 & 1,141 \\
\hline 1765 & 17,109 & 1,296 \\
\hline 1820 's & 16,000 & 2,000 \\
\hline 1880 & 20,621 & 5,485 \\
\hline 1900 & 23,036 & 3,500 \\
\hline 1920 's & & \\
\hline 1940 & $\begin{array}{l}15,616 \\
(6,467 \text { en el espacio urbano, } 9,149 \text { en el rural })\end{array}$ \\
\hline 1950 & 18,287 & \\
\hline 1960 & $\begin{array}{l}27,294 \\
(13,675 \text { en el espacio urbano, } 13,619 \text { en el rural) }\end{array}$ & \\
\hline 1970 & $\begin{array}{l}18,467 \\
(11,719 \text { en el espacio urbano, } 6,748 \text { en el rural) }\end{array}$ & \\
\hline 1980 & 19,694 & 13,031 \\
\hline 1990 & 24,497 & 18,089 \\
\hline 2000 & 28,110 & 21,291 \\
\hline 2005 & 28,462 & 21,656 \\
\hline
\end{tabular}

Cuadro 1: El cuadro de la evolución demográfica de la jurisdicción total o del municipio de Jalostotitlán y la población del pueblo y la cabecera municipal de Jalostotitlán ${ }^{90}$

${ }^{89}$ Entre 1950 y 1960, hubo un incremento de la población de cerca de 9,000 personas. Hubo una disminución de casi el mismo número de personas entre 1960 y 1970. Cabe mencionar que en estas dos décadas hubo cambios importantes en la migración hacia Estados Unidos. En 1964 se concluyó el Programa Bracero que emprendió la salida masiva de los jalostotitlenses como migrantes laborales en Estados Unidos. Desde mediados de los años sesenta, ha aumentado el número de los migrantes que trataban de entrar a Estados Unidos de manera indocumentada. Si se toma en cuenta este cambio en patrón migratorio, se puede interpretar que una parte importante de la población migrante que salió de Jalostotitlán regresó al municipio por el fin del contrato de trabajo migratorio o por la deportación masiva antes de 1960. Pero, después de la conclusión del Programa Bracero, salieron un gran número de personas a Estados Unidos.

${ }^{90}$ Fuentes de datos: Gutiérrez Gutiérrez (1985: 135; 162; 163; 173; 292), López Cortés (1999: 70), INEGI (1984), X Censo General de Población y Vivienda, 1980, México; INEGI (1991), XI Censo General de Población y Vivienda, 1990. Resultados Definitivos. Tabulados Básicos, México; INEGI (2001), XII Censo General de Población y Vivienda, 2000. Resultados Definitivos. Tabulados Básicos, México; INEGI (2002), XII Censo General de Población y Vivienda, 2000. Principales Resultados por Localidad, México; INEGI (2006), II Conteo de 
En este proceso de la evolución demográfica de la cabecera municipal, Jalostotitlán fue elevado oficialmente a la categoría de ciudad en 1970. Después de su transformación formal en el espacio urbano, en Jalostotitlán siguió aumentando el número de habitantes. En el año 2005, la cabecera municipal contaba con 76.09 por ciento de la población total del municipio. El incremento de los habitantes en la cabecera municipal durante más de un siglo es sorprendente si se compara esta proporción de la totalidad de la población del municipio con el censo de 1880. Entonces, la cabecera municipal sólo tenía aproximadamente 26 por ciento de la población total del municipio.

En el proceso de la evolución demográfica de Jalostotitlán desde su fundación en el siglo XVI hasta la presente fecha, el territorio del pueblo de Jalostotitlán transformado hoy en día en una ciudad también se ha extendido. En el siglo XVI, el pueblo se extendía sólo en el espacio en donde se ubica el actual centro de la cabecera municipal. Contaba sólo con 25 manzanas de terreno del centro. Sus límites territoriales llegaban hasta el Río de Jalostotitlán en el oeste y el sur, hasta Av. Juárez en el este y hasta dos cuadras norte del templo parroquial en el norte. Pero, tras siglos, el territorio de la cabecera municipal y de su espacio urbano se ha extendido enormemente. ${ }^{91}$ En los años treinta del siglo $\mathrm{XX}$, los límites de la cabecera municipal eran el río, el santuario y el panteón. Pero, actualmente su territorio geográfico se extiende más allá de los límites de aquel período.

La transición del campo a la ciudad en Jalostotitlán también se observa en las actividades económicas de sus habitantes. Desde la época colonial, la agricultura y la ganadería habían sido la principal fuente de trabajo para la mayoría de los jalostotitlenses. Sin embargo, como demuestra la gráfica 1, la proporción que ocupa el sector primario en la población económicamente activa en el nivel

Población y Viviendas, 2005, Resultados Definitivos. Tabulados Básicos, México. Durante el trabajo de campo, no pude conseguir los datos demográficos de la localidad de Jalostotitlán de 1900, 1940, 1950, 1960 y 1970. Pero si se compara el número de habitantes en el espacio urbano del municipio en 1940 con el de 1960 y el de 1970, se observa la tendencia notoria al abandono del espacio rural a favor del espacio urbano como lugar de residencia.

${ }^{91}$ Véase el mapa anexado en el libro de Gutiérrez Gutiérrez (1985). 
municipal disminuyó radicalmente entre 1960 y 1970, en cambio, se ha incrementado el número de personas dedicadas al sector de la industria manufacturera, el comercio, los servicios y la construcción hasta el año 2000.

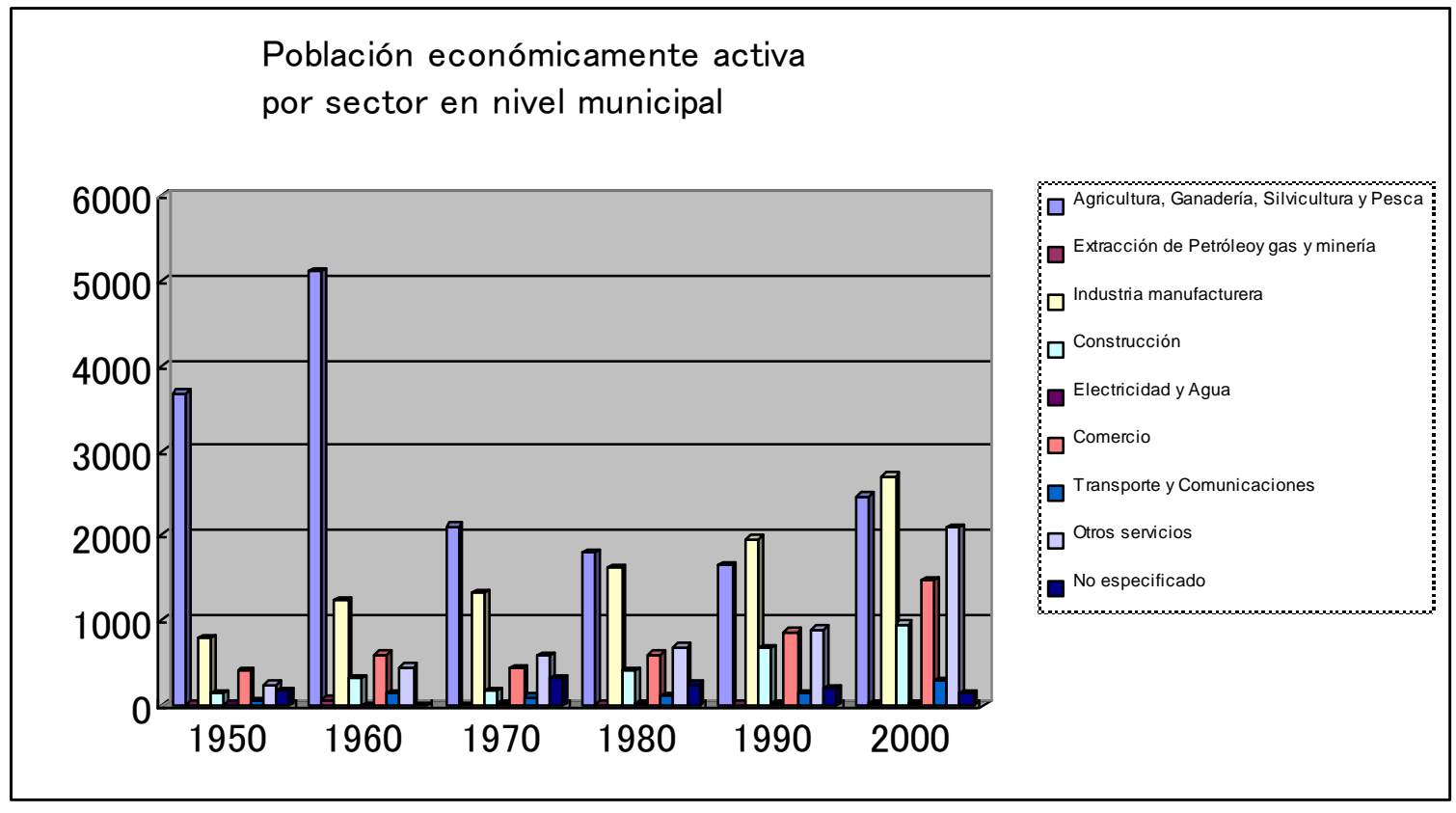

Gráfica $1^{92}$

Estos trabajos se han desarrollado principalmente en la urbe municipal, es decir, en la cabecera. La apertura de las carreteras que comenzó en Los Altos de Jalisco en los años cuarenta y el incremento de la población en la cabecera municipal aumentaron las demandas de labores urbanas. En suma, durante las últimas cuatro o cinco décadas Jalostotitlán ha pasado de ser una sociedad ranchera a otra urbana tanto en términos de número de población como en términos de tipo de trabajo.

A esta transformación de Jalostotitlán en el espacio urbano el fenómeno de migración hacia Estados Unidos ha contribuido de una manera importante. Cuando los migrantes se iban de Jalos, dejaban a sus familias instaladas en la cabecera municipal por la seguridad y comodidad en vez de dejarlas solas en el

92 Fuente de datos: López Cortés (1999: 71); INEGI (1991), XI Censo General de Población y Vivienda, 1990. Resultado Definitivos. Tabulados Básicos, México; INEGI (2001), XII Censo General de Población y Vivienda, 2000. Resultado Definitivos. Tablados Básicos, México. 
campo. ${ }^{93}$ Además, debido a la afluencia de dólares a Jalostotitlán, comenzó un auge en la ampliación y la construcción de casas no necesariamente con los materiales tradicionales, sino con materiales finos y un estilo arquitectónico diferente. Por ejemplo, entre 1990 y 2000, hubo un aumento de más de 1,000 viviendas en el nivel municipal. ${ }^{94}$ Este auge en la construcción de viviendas, la concentración de la población en la cabecera municipal y el vínculo económico y social de sus habitantes con el país del norte han permitido crear nuevos trabajos urbanos.

La tecnología, el dinero, los objetos y la información que los migrantes enviaban y llevaban desde el contexto urbano de Estados Unidos han contribuido, de manera significativa, al desarrollo social y económico del lugar de origen y han inscrito nuevos signos y elementos culturales en la vida cotidiana de los habitantes de Jalostotitlán. Las remesas se invirtieron en la ampliación y construcción de casas de otro estilo y en negocios en la cabecera municipal. Las ideas, modas, nuevos aparatos electrónicos y automóviles derivados de Estados Unidos han cambiado los modos de vida, formas de vestir, lenguaje y comportamientos humanos.

Estas remesas económicas y sociales que contribuyeron a la transformación de Jalostotitlán en el espacio urbano no necesariamente han sido llevadas por los migrantes de forma individual, sino que también fueron enviadas algunas veces de forma colectiva ${ }^{95}$ Por ejemplo, en 1967, los migrantes radicados en el sur de California fundaron el Club Social Jalostotitlán de Los Ángeles. A través de la celebración del Baile de Coronación de la reina, colectaron una donación entre los migrantes originarios de Jalostotitlán con el fin de dar apoyos económicos y materiales a su lugar de origen en donde todavía había mucha pobreza en aquella época. Las ambulancias que donó el Club Social a principios de los años setenta

93 Gutiérrez Gutiérrez (1985: 292)

94 INEGI (1991), XI Censo General de Población y Vivienda, 1990. Resultado Definitivos, Tabulados Básicos, México; INEGI (2001), XII Censo General de Población y Vivienda, 2000. Resultados Definitivos, Tabulados Básicos, México.

${ }^{95}$ Véase el concepto de "remesas sociales" que propone Peggy Levitt (2001). Ella analiza los flujos hacia el lugar de origen de los migrantes de objetos, dinero, información, ideas, valores y símbolos en términos de "remesas sociales". 
contribuyeron de manera fundamental al servicio de la Cruz Roja de Jalostotitlán fundada en la misma década.

Esta historia de transformación de Jalostotitlán articulada con la migración hacia Estados Unidos se puede entender mejor con el concepto convencional de desarrollo del mundo rural mexicano. Según el modelo convencional de desarrollo basado en el pensamiento modernista, el campo es un espacio inmóvil y de atraso, en cambio, la ciudad es un espacio que se define en oposición a lo rural, es un espacio dinámico y de innovación, progreso y desarrollo. En esta definición, el desarrollo significaba la eliminación del espacio rural y la urbanización y la industrialización de la sociedad por medio del cambio tecnológico y la mecanización de las formas de producción (Morales Hernández, 2004; Ramírez y Arias, 2002). Pero en realidad, la mayor parte de los campos quedaron al margen de esa transformación en el proyecto de desarrollo moderno (Ramírez y Arias, 2002). Muchas sociedades rancheras del occidente de México, como Jalostotitlán, tenían escasos recursos para la industrialización de la naturaleza y la urbanización.

En esta situación, para muchos habitantes de Jalostotitlán cuyos familiares ya habían tenido experiencias migratorias en Estados Unidos, la migración fue una manera muy accesible para buscar el progreso. De hecho, la mayoría de los jalostotitlenses que dejaron su tierra natal para irse a Estados Unidos en este proceso de transición del campo a la ciudad buscaban mejores oportunidades de trabajo en Estados Unidos. Por ejemplo, un migrante nacido en un rancho, quien trabajaba en Indianápolis, en el estado de Indiana, explicó su motivo de salida de Jalostotitlán de la siguiente manera:

Salí por la ambición, por el dinero, por el deseo de progresar. Yo, desde que tenía cinco años, tenía la ilusión de hacer algo en la vida [...] en Jalos las ambiciones de un muchacho no pueden ser colmadas, porque no hay dinero. ${ }^{96}$

Para otro migrante, quien vivía en South Gate, condado de Los Ángeles, la búsqueda del progreso era también su motivo de irse al Norte:

${ }^{96}$ Jáuregui Pérez (1981: 137). 
Estados Unidos de Norte América, para mí, ha significado progreso. Con este deseo vine a esta nación, con el afán de progresar en todos los sentidos, principalmente en el aspecto económico. Llegué buscando un nivel de vida superior al que teníamos allá, en Jalos: lograr el progreso anhelado. ${ }^{97}$

La siguiente narrativa de un migrante de Sacramento explica cómo los jóvenes de Jalostotitlán construían su sueño americano y veían el progreso y un futuro en Estados Unidos.

A decir verdad, yo salí de mi pueblo natal por ambición. Cuando, en mis tiernos años de infancia, estudiaban en Jalostotitlán, la educación primaria, veía a los norteños que llegaban manejando carros flamantitos, vestían ropa muy buena y cargaban muchos dólares, en su cartera. Yo me deslumbraba. Las posibilidades de seguir estudiando, eran muy escasas. En cambio, venirse al Norte y trabajar y comprar carros y ropa buena, parecía ser el asunto más fácil del mundo. Especialmente para mí, que tenía varios hermanos y parientes en Estados Unidos. La vuelta a esta nación se me presentaba como el siguiente paso que había que dar, una vez terminaba la educación primaria. ${ }^{98}$

Lo que se destaca aquí es que la salida de los jalostotitlenses hacia Estados Unidos con el fin de realizar el sueño americano de alcanzar el progreso y tener un futuro mejor, abandonando el mundo rural mexicano como espacio de estancamiento económico y de atraso, ha contribuido, de alguna manera, como expliqué antes, a la transformación de su terruño en la ciudad. En otras palabras, los jalostotitlenses han logrado articular el proceso migratorio hacia el Norte como el mundo de progreso y las conexiones transnacionales que han permitido introducir dinero, objetos y nuevas ideas y formas de vida a Jalostotitlán con el proceso de transformación urbana de Jalostotitlán para lograr el desarrollo moderno local.

\section{DEL CAMPO A LA CIUDAD EN EL SUR DE CALIFORNIA}

La transición del campo a la ciudad también se dio en el espacio de vida de los migrantes jalostotitlenses en el sur de California. Este proceso se dio principalmente en dos modos. En primer lugar, en las últimas cinco décadas, la mayoría de los jalostotitlenses del sur de California han tendido a abandonar

\footnotetext{
97 Jáuregui Pérez (1981: 387).

98 Jáuregui Pérez (1981: 318)
} 
labores agrícolas en favor de labores urbanos. Durante la época del Programa Bracero (1942-1964), el sector de la agricultura fue el destino laboral principal que absorbía a las corrientes de trabajadores migrantes contratados. ${ }^{99}$ Pero, después de la abolición de dicho programa, los migrantes mexicanos tendían a trabajar menos en este sector laboral. ${ }^{100} \mathrm{El}$ destino hacia el cual se dirigían las corrientes de estos trabajadores migrantes cambió. Por ejemplo, según los resultados de las investigaciones cuantitativas realizadas por Portes y Bach en los años setenta, la ocupación de los migrantes mexicanos se concentraba en los sectores laborales diferentes de la agricultura (1985: 185). Desde los años sesenta, ha aumentado la demanda de la mano de obra barata en el sector de la construcción, servicio y otras labores urbanas e industriales.

La migración jalostotitlense no ha sido la excepción de esta transición ocupacional de los migrantes mexicanos. De hecho, en la investigación cuantitativa realizada en el municipio de Jalostotitlán en los años ochenta, se observa una tendencia a abandonar la agricultura en favor de actividades laborales urbanas. (González de la Rocha y Escobar Latapí, 1990).

Esta transición ocupacional de los migrantes jalostotitlenses también se observa en las trayectorias laborales de mis entrevistados. Un migrante jubilado, nacido en 1930 en Jalostotitlán y radicado actualmente en Norwalk, en el condado de Los Ángeles, llegó por primera vez a California en 1953. Su primer trabajo en Estados Unidos era la pizca de uvas y duraznos en un campo agrícola de Fresno. Un contratista mexicano americano le llevó a él y a otros ocho paisanos de su tierra natal. Antes de ir a Estados Unidos, trabajaba en el rancho de su familia. Seis meses después de haber trabajado en Fresno, se fue a Los Ángeles con algunos de sus paisanos, porque en invierno no había el trabajo de pizca de frutas. Se quedaron en la casa de una familia originaria de Jalos en esta ciudad y consiguió trabajo en una fábrica. Ahí trabajó durante seis meses y luego regresó a Jalos porque lo deportaron. En 1955, volvió a Los Ángeles. A finales de los años cincuenta le dieron una carta para solicitar la visa en su trabajo de empaque de

\footnotetext{
99 Durand (1994: 133).

100 Portes y Walton (1981: 54); Cornelius (1989: 5).
} 
cajas de cartón y consiguió su estancia legal. Luego, entró a trabajar en una fábrica de fundición de patrones italianos.

Otro migrante jubilado nacido en Jalos en 1934 y radicado en el condado de Orange llegó en 1956 a La Habra, una ciudad en el condado de Orange donde había cerca de 30 familias originarias de Jalostotitlán en los años cincuenta y los años sesenta. Ahí trabajó en huertas de limón con su tío que había llegado antes que él. Seis meses después de haber trabajado pizcando limón, se fue a Los Ángeles. Consiguió trabajo en un hotel de lujo, donde estaban trabajado entonces muchos paisanos de Jalos. Trabajaba en la limpieza y como busboy (ayudante de mesero). En 1957, entró a trabajar a una compañía empacadora de tomate en el condado de Orange. Luego, en 1975, consiguió un empleo en una compañía que hacía pozos petroleros. En 1985, entró a trabajar en una tienda. Cinco años después, consiguió otro empleo de repartidor de medicamentos en un hospital.

Otro migrante jubilado de South Gate, en el condado de Los Ánleges, de 59 años en el momento de la entrevista en 2004, había llegado a California a principios de los años sesenta cuando tenía 16 años. En el momento de su llegada, sus hermanos y su padre ya habían estado en California. En Jalostotitlán, trabajaba en el rancho de su familia. Su primer trabajo en Estados Unidos fue un trabajo de lavacoches en Venice. Después entró al restaurante de un hotel del aeropuerto de Los Ángeles. Ahí trabajó durante 11 años. Comenzó a trabajar como lavaplatos. Pero luego, ascendió de busboy a mesero. Luego, le dieron el cargo de "mayordomo" del departamento de banquetes. ${ }^{101}$ Tuvo 40 o 50 personas trabajando con él. La mayoría de sus trabajadores eran de Jalostotitlán. A mediados de los años setenta, entró a General Motors. Ahí trabajó como armador de vehículos durante 25 años.

Lo que demuestran estas trayectorias laborales es que la transición ocupacional del campo a la ciudad entre los migrantes jalostotitlenses del sur de California había comenzado durante el periodo del Programa Bracero. Iniciando el trabajo migratorio en el campo agrícola, pronto abandonaron el campo y buscaron oportunidad de empleo en las ciudades. De cierta manera, la labor agrícola no les

${ }^{101}$ Aquí, el mayordomo se refiere al jefe de grupo de trabajo. En inglés, foreman. 
convenía porque el período laboral sólo duraba algunos meses y cuando terminaba la temporada de cosecha, ya no había tantos trabajos en el campo. Por eso, se dirigieron a las ciudades (aunque ahora como indocumentados). Aunque tuvieron poco tiempo de estancia en Estados Unidos cuando decidieron buscar trabajo en el espacio urbano, las redes sociales de los jalostotitlenses construidas en el sur de California les facilitaron conseguir hospedaje y acomodo en trabajos urbanos. Otro punto importante es que en el transcurso de su vida migratoria ellos consiguieron empleos en sectores laborales diferentes de los que tenían en Jalostotitlán. También se observa un "ascenso" cada vez que cambiaban de trabajo o en términos generacionales. Esto quiere decir que al cambiar de lugar de trabajo, buscaron un lugar de trabajo más estable que el anterior o que los migrantes que llegaron a California con una edad más temprana que otros se insertaron en el sector laboral urbano más rápido que las generaciones anteriores.

El resultado de la investigación cuantitativa realizada en el municipio de Jalostotitlán en los años ochenta por los investigadores coincide con esta tendencia ocupacional de mis informantes. Según González de la Rocha y Escobar Latapí (1990), el resultado de la encuesta muestra que los migrantes mayores de 50 años ocupaban labores agrícolas más que los migrantes jóvenes, en cambio, la proporción de los jóvenes que tenían trabajo en los sectores de industria y de servicio era mayor que la proporción de los migrantes mayores de 50 años, y que los migrantes más viejos se concentraban en la categoría de trabajadores manuales no calificados y las demás generaciones en la categoría de trabajadores manuales calificados (González de la Rocha y Escobar Latapí, 1990: 538-541).

La concentración de los jalostotitlenses en ciertos sectores laborales urbanos y ciertas localidades en las zonas urbanas del sur de California tiene que ver, de cierta manera, con el ascenso laboral de los migrantes. Primero, llegaron algunos migrantes a la cocina del hotel y a las fábricas, y luego, en el transcurso de su vida laboral, ascendieron de puesto en el trabajo y ocuparon el cargo de "mayordomo" (la persona encargada del grupo de trabajadores). Este cargo les facilitaba invitar a sus familiares y amigos de Jalos a trabajar con ellos cuando había vacantes y 
necesidad de trabajadores extras en sus trabajos. Por ejemplo, el migrante que trabajaba como encargado del departamento de banquetes en el hotel del aeropuerto de Los Ángeles, enviaba un anuncio de trabajo de medio tiempo a un billar del sur de California que frecuentaban los coyotes y los migrantes recién llegados de Jalostotitlán, cuando había muchos banquetes que necesitaban 10 o 15 trabajadores extras en el hotel. Hasta los años ochenta, ya habían surgido varios migrantes jalostotitlenses que establecieron sus propios negocios en los sectores de industria, servicio y de comercio en el sur de California. Estas empresas migrantes han contribuido a ofrecer trabajos a sus paisanos. De este modo, los jalostotitlenses se han asentado en varias localidades de las zonas urbanas del sur de California.

Pero la transición del campo a la ciudad no sólo se dio en el tipo de trabajo de los migrantes jalostotitlenses. La segunda forma de transformación urbana en el espacio de vida de la sociedad receptora es que las localidades asentadas por los jalostotitlenses del sur de California han vivido un crecimiento urbano. Por ejemplo, cuando trabajaba en la pizca de limón el migrante jubilado que llegó a La Habra, en el condado de Orange, en 1956, tumbaron los árboles de limón que él pizcaba después de terminar esa cosecha. Ahora en las zonas donde había huertas de limones están construidas casas y edificios. La huerta de limones donde él trabajaba, ahora es una bodega de la cadena de supermercado Albertsons. Desde los años cincuenta, la población de La Habra había empezado a crecer drásticamente. En 1950, La Habra sólo tenía 4,961 habitantes, para 1960, había 25,136; en 1970, se incrementó a 41,350; y para el año 2000, llegó a $58,974 .^{102}$

Anaheim, la ciudad en donde actualmente se concentran los jalostotitlenses en el condado de Orange, también mostró un enorme crecimiento demográfico durante las últimas cinco décadas. En 1950, su población sólo alcanzaba 14,556 habitantes. Pero, en 1960, el número de habitantes era 104,184; en 1970, 166,701; en 1980, 219,494; en 1990, 266,406; y en 2000, 328,014. Cabe destacar que este incremento demográfico ha sido acompañado con el crecimiento de la

${ }^{102}$ April Decennial Census of Population, U.S. Census Bureau. 
población hispana. De hecho, 46.8 por ciento de la población de Anaheim era hispana en $2000 .^{103}$

Uno de los factores importantes por los cuales se incrementó la población hispana es que estas dos localidades del condado de Orange han pasado de ser espacios laborales agrícolas a ser centros urbanos e industriales. Hasta los años sesenta, como lo indica el nombre del condado, el paisaje de estos dos lugares estaba lleno de huertas de cítricos. Sin embargo, las huertas fueron tumbadas para construir viviendas, fábricas y carreteras. En este proceso de transformación del espacio rural en uno urbano e industrial, aumentó la demanda de mano de obra barata en los sectores industrial, de la construcción y de servicio. Ahí encontraron nuevas fuentes de empleo miles de migrantes mexicanos que se dedicaban a labores agrícolas durante el período del Programa Bracero y la creciente población migrante indocumentada. El establecimiento de Disneylandia en Anaheim en el verano de 1955 era un acontecimiento simbólico de este proceso de transformación de la localidad rural en un espacio laboral diferente de la agricultura, dado que este sitio de entretenimiento fue construido encima de huertas de naranjas de 160 hectáreas que compró Walt Disney. ${ }^{104}$

En este proceso de crecimiento demográfico de los asentamientos de los jalostotitlenses en el condado de Orange, también las parroquias de las iglesias católicas locales de las localidades pobladas por los migrantes mexicanos se han desarrollado. Por ejemplo, la parroquia de la Iglesia de Nuestra Señora de Guadalupe (Our Lady of Guadalupe Church) en La Habra contaba con 2,055

${ }^{103}$ April Decennial Census of Population, U.S. Census Bureau. En las localidades del condado de Los Ángeles, donde se han asentado varias familias originarias de Jalostotitlán también se observa el crecimiento demográfico acompañado con la alta proporción de la población hispana. Por ejemplo, South Gate, la localidad del condado de Los Ángeles, donde había cerca de 20 familias originarias de Jalostotitlán a principios de los años setenta, se ha convertido en una localidad poblada por migrantes hispanos. Según el censo de 2000, vivían ahí 96,375 habitantes, 92 por ciento de los cuales eran de origen hispano (U.S. Census Bureau, 2000).

${ }^{104}$ Un dato interesante sobre Disneylandia relacionado con la migración mexicana es que una forma común entre los migrantes indocumentados de entrar a Estados Unidos durante el período de los años sesenta y los años ochenta era pasar la frontera con pasaporte y visa vigentes como turistas. Muchos migrantes se iban a Disneylandia como turistas en "tours" que organizaban las agencias de viaje. Pero, después de terminar el recorrido en el reino de la fantasía, los camiones turísticos regresaban semivacíos (Durand 1994: 137). 
familias registradas en 1966. Pero en 1997, el número de familias registradas en la parroquia llegó a 4,600. Para responder al crecimiento de los creyentes de la iglesia local, se tuvo que ampliar y reconstruir la iglesia tres veces después de que se construyó la primera iglesia en 1928. La mayoría de las personas que han sostenido este crecimiento demográfico de la parroquia en La Habra han sido hispanos. ${ }^{105}$ Por ejemplo, la población hispana de La Habla ocupa $49.0 \%$ de la población total de la ciudad. ${ }^{106}$ Cuando me hospedaba en la casa de don Antonio ubicada cerca de esta iglesia, él y su esposa doña Teresa me llevaban ahí para asistir a la misa de la tarde. En la misa que daba en español un sacerdote originario de Los Altos de Jalisco estaban ocupadas las bancas del interior de la iglesia que tenían capacidad para aproximadamente 1,000 personas. En esta iglesia, hay seis misas los domingos, dos de las cuales se celebran en español.

Lo que era relevante entre los migrantes jalostotitlenses en esta transformación de los asentamientos en las ciudades con la mayor población hispana fue el surgimiento de empresas de migrantes. ${ }^{107}$ En los años setenta y ochenta ya existían varias personas originarias de Jalostotitlán que trabajaban como corredores de bienes raíces y algunos tenían sus propias agencias. Tener personas dedicadas a esta área de trabajo era una ventaja entre los jalostotitlenses del sur de California para tener información del cambio en el precio del terreno y vivienda y para comprar las casas antes de que el precio se elevara por el rápido incremento de la población en cierta zona urbana. La compra de vivienda es uno de los factores que prolongaron la estancia de los migrantes en Estados Unidos y les permitieron establecerse en aquellos lugares. Para los migrantes jalostotitlenses que obtuvieron la licencia como vendedores de bienes raíces, el proceso de transformación de los asentamientos en las ciudades con la creciente población hispana que ha sido muy marcado desde los años setenta era

105 Our Lady of Guadalupe Church Family Album, 1997, Publicado por la parroquia de Our Lady of Guadalupe Church en La Habra.

${ }^{106}$ April Decennial Census of Population, U.S. Census Bureau (2000).

107 Mike Davis usa el término "suburbios transnacionales" para explicar el proceso de transformación de grandes ciudades acompañado con el incremento de la población latina y con la proliferación de gente, objetos, el idioma y prácticas sociales culturales derivados de lugares y países de origen de los inmigrantes latinos en las ciudades en Estados Unidos (2000: 80). 
un buen contexto social para encontrar clientes. Por ejemplo, un migrante que comenzó esta carrera desde 1976 aumentaba regularmente las comisiones que ganaba por la venta de bienes raíces. Por ejemplo, en 1977, ganó 19 mil dólares de comisión, y en 1978, obtuvo más de 43 mil dólares de comisiones. En 1980, logró vender más de dos millones de dólares en bienes raíces. ${ }^{108}$

Cabe mencionar que los jalostotitlenses que han recibido el beneficio económico de la compra y venta de bienes inmuebles no sólo son los corredores profesionales de bienes raíces. En el trabajo de campo en el sur de California, conocí a jalostotitlenses que han aumentado sus bienes por la compra, venta y renta de viviendas y terrenos. Cuando el precio de los terrenos y viviendas eran relativamente bajos en sus asentamientos que comenzaban a urbanizarse, compraron sus primeras casas. Luego, las vendían al subir el precio y compraron otras casas en otras zonas que aún no subían tanto de precio. De hecho, no son pocos migrantes los que han comprado más de dos casas en su vida migratoria en California. Hay algunos migrantes jubilados que habían comprado departamentos y terreno con sus familiares y actualmente rentan sus propiedades para tener un ingreso extra mensual además de la pensión.

Otro sector laboral del cual surgieron las empresas de migrantes jalostotitlenses es la industria. Por ejemplo, un migrante que trabajaba en una fábrica de acabado de metales en Los Ángeles, abrió su propio negocio en Anaheim aprovechando su experiencia por haber trabajado en esa fábrica. Era una fábrica del tratamiento de metales que hacía partes de computadoras o cajas para registros electrónicos, para recubrir postes o para alumbrado de parques. Al principio de los años ochenta, esta compañía contaba con 35 empleados. ${ }^{109}$

También surgieron las empresas de los jalostotilenses en los sectores de comercio y de servicio. La administración de supermercados que se especializan en la venta de alimentos para la gastronomía mexicana es el área de trabajo en el cual se insertaron algunos migrantes jalostotitlenses. Por ejemplo, el difunto don Miguel González Jiménez y su hijo Miguel González Reynoso pusieron el primer

108 Jáuregui Pérez (1981: 88-92).
109 Jáuregui Pérez (1981: 22-25). 
establecimiento comercial en Anaheim en enero de 1980. Era una tienda donde se vendían abarrotes mexicanos, carnes y un poco de ropa y calzado. ${ }^{110}$ El negocio tuvo un gran éxito. Luego, se abrieron otros locales comerciales. Actualmente Northgate González Market es una de las cadenas de supermercados más grandes para consumidores mexicanos en el condado de Orange. Hasta otoño de 2004, la familia González llegó a tener 17 supermercados en el condado de Orange y en la parte oeste del condado de Los Ángeles. ${ }^{111}$

Otro migrante jalostotitlense que llegó a California en 1961 abrió un hotel y un restaurante junto con su esposa en la Isla Catalina a finales de los años sesenta y a finales de los años setenta respectivamente. Este migrante inició su vida migratora lavando platos. Luego, ascendió a busboy. En dos años tuvo el puesto de jefe de cocineros. En 1964, llegó a la Isla Catalina. Ahí trabajó de busboy y en la limpieza en el hotel que él y su esposa compraron en 1968. Luego, en 1977 abrieron un restaurante de comida mexicana. ${ }^{112}$

Uno de los factores fundamentales del surgimiento de los empresarios migrantes jalostotitlenses y de la expansión de sus negocios es el crecimiento demográfico de la población mexicana en el proceso de urbanización de los asentamientos de los jalostotitlenses en el sur de California. Los negocios que levantaron estos migrantes aprovechando sus experiencias laborales y migratorias previas, podían encontrar tanto la mano de obra barata como la clientela entre la masa de los migrantes mexicanos que estaba contribuyendo al crecimiento urbano de sus asentamientos.

Al principio, estos empresarios jalostotitlenses trabajaban, como los demás paisanos, en algunas fábricas, restaurantes, hoteles, etc., pero, en el transcurso de sus experiencias de trabajo para algún patrón o alguna compañía, modificaron lo que eran su "sueño americano". Antes de llegar a Estados Unidos, el progreso les significaba a los migrantes jalostotitlenses simplemente trabajar en el norte. Pero, después de haber trabajado durante años como empleados, algunos

110 Jáuregui Pérez (1981: 26-30).

${ }^{111}$ En el condado de San Bernardino, también existe otra cadena de supermercado para consumidores mexicanos, que administra una familia originaria de Jalostotitlán.

112 Jáuregui Pérez (1981: 38-42). 
migrantes, como estos migrantes empresarios, propusieron otra meta y encontraron el progreso en sus propios negocios. En el libro escrito por don Severiano Jáuregui Pérez, aparecen varias entrevistas con personas que abrieron negocios, en las cuales explican su nueva idea de progreso del siguiente modo:

Paisano de Jalos, por favor, los que tengan oportunidad de iniciar su negocio propio, no se detengan ante nada ni nadie. Sean ustedes sus propios patrones. Traten de superarse de ir siempre hacia arriba. ${ }^{113}$

Dedíquense a un negocio propio; pero no le trabajen, por un puño de centavos, a una compañía. Las compañías acaban con las fuerzas de un individuo y le atrofian su mente. ${ }^{114}$

Amigos lectores, busquen todos la forma de independizarse, con un negocio propio. Cualquier comercio, chico o grande; pero no trabajen para otros. ¡Es tan bonito manejarse uno mismo! [...] Que se termine eso de estar siempre esperando que otro nos diga qué es lo que tenemos que hacer. Con nuestro propio modo de ganarnos la vida seremos más felices y más prósperos y, sobre todo, nos desarrollaremos más en nuestro ingenio y en nuestras capacidades, porque somos susceptibles de un crecimiento ilimitado. ${ }^{115}$

Las ventajas de un negocio propio son muy grandes [...] el dueño se manda solo; se trabaja, a discreción, las horas que sean necesarias para el progreso del negocio...en el negocio, existe siempre la esperanza de la superación. ${ }^{116}$

Estas narrativas explican la idea de no conformarse con el trabajo y la vida que tienen como trabajadores migrantes en ese país, tener una vida independiente y ser dueños de su propia vida. Esto es la idea de progreso, superación y triunfo que sostenía el surgimiento de empresarios migrantes.

Sin embargo, no todos los migrantes jalostotitlenses han realizado este nuevo sueño americano de ser empresarios. La mayoría de los migrantes han seguido trabajando para alguna compañía como empleado asalariado. Como comenté en el apartado anterior, los migrantes jalostotitlenses salieron de su tierra natal en busca de un mejor futuro y progreso en el Norte. Pero, al desplazarse a Estados Unidos y al haber trabajado durante años y décadas en ese país, ellos se

\footnotetext{
113 Jáuregui Pérez (1981: 83).

114 Jáuregui Pérez (1981: 224).

115 Jáuregui Pérez (1981: 265).

116 Jáuregui Pérez (1981: 264).
} 
situaron en otro contexto sociocultural que también les hizo reflexionar sobre su sueño inicial de buscar el progreso y el desarrollo moderno abandonando su tierra natal para trabajar en Estados Unidos. En su libro don Severiano hace una reflexión del "precio" que los migrantes han pagado para vivir en Estados Unidos: "hemos pagado el precio, a veces demasiado alto, de nuestra estancia en este país" (8). ¿Cuál es el precio que han pagado? ¿Qué es lo que han sacrificado para buscar el progreso en Estados Unidos? En las narrativas de algunos migrantes jalostotitlenses, se puede entrever una respuesta:

La venida de Jalos fue una necesidad. ¡Maldigo la hora en que abandoné Jalos! Es triste dejar la patria, el pueblo, la familia, padres y hermanas. ¡Pero yo no tenía otro recurso! ${ }^{117}$

llegamos, en busca de superación. Eso es. Superación, es la palabra que nos anima a todos los exhabitantes de Jalostotitlán [...] A nuestro pueblo querido seguimos recordándolo con mucho cariño, no obstante que las circunstancias nos hacen salir a otros senderos, en busca de un porvenir, o en busca de una vida mejor para nuestras propias familias, por encima de todo, Jalos sigue viviendo en nuestro espíritu [...] Desgraciadamente, no tenemos ahí, las fuentes de trabajo, la industria necesaria para volver todos a Jalostotitlán. Si estas condiciones se realizaran, creo que nadie saldría de nuestro querido terruño. ${ }^{118}$

de todas maneras no me gusta esta nación para vivir siempre. Se vive muy alejado de parientes y amigos. Además, la vida es demasiado monótona, extremadamente rutinaria. Si estuviera rodeado de todos mis parientes y amigos, sería más feliz en esta tierra tan extraña. ${ }^{119}$

Se puede leer en estas narrativas el dilema que experimentan los migrantes. A pesar de que hayan podido cruzar la frontera y permanecer en la tierra prometida de "progreso", no han podido sentir la satisfacción por completo con su vida migratoria porque han tenido que separarse de su terruño y de sus seres queridos y estan atrapados en la vida solitaria, monótona y rutinaria.

También este dilema que experimentan los migrantes se puede interpretar a partir de sus experiencias de la alienación en Estados Unidos. Los jalostotitlenses dejaron su tierra natal y viajaron hacia el Norte en busca de mejores

\footnotetext{
117 Jáuregui Pérez (1981: 32).

118 Jáuregui Pérez (1981: 50)

119 Jáuregui Pérez (1981: 134).
} 
oportunidades económicas. En este proceso migratorio, como expliqué en el apartado final del capítulo 2, ellos fueron introducidos en la economía estadounidense como mano de obra barata y se convirtieron en trabajadores que experimentan la alienación en varias formas: debido a sus condiciones de trabajar para los otros y a las características del trabajo con operaciones simples y repetitivas, para ellos el trabajo aparece como una actividad rutinaria a través de la cual no puedan buscar autorrealización; además, por sus condiciones de ser subalternos en términos sociales, económicos y políticos y ser vistos culturalmente como "otros", han vivido las experiencias de alienación tanto del trabajo como de la sociedad receptora; pero la posibilidad de anular la alienación dentro de ese país, no está tan abierta para ellos. En este contexto, los migrantes han experimentado la añoranza por Jalostotitlán. En vez de dirigir la mirada hacia adelante y hacia el futuro, como las narrativas de los migrantes empresarios, apuntando sus metas en el nivel más alto y en el mejor éxito económico, ellos miran hacia su pasado y hacia su terruño que han dejado atrás. Han dado significados positivos a su terruño que se encuentra en el "exterior" del tiempo, el espacio y la realidad que viven como sujetos alienados, en cambio, han proyectado la imágenes negativas en Estados Unidos visto como espacio de trabajo, como ilustran las siguientes narrativas:

Extraño tanto a mi pueblo. Todo se extraña: las campanas de la Iglesia, los amigos, las fiestas...Todo. Todo se extraña. Siempre he tenido en mi mente el deseo de regresar a mi querido Jalos. Aunque me lleven en un cajón; pero yo tengo que regresar a mi pueblo tan querido. Creo que no hay un paisano que tenga malos recuerdos de nuestro pueblo. ${ }^{120}$

Me gustaría regresar a mi pueblo, a vivir allá [...] Yo me voy al rancho y soy feliz. Recibo el aire fresco y se me olvidan todos los problemas de la vida. ${ }^{121}$

mi impresión del Norte no fue muy placentera...comprendo que todo ser humano requiere y necesita confort; pero cuando la abundancia de bienes materiales ahoga las aptencias del espíritu, el hombre pierde el verdadero sentido de vida. ${ }^{122}$

\footnotetext{
120 Jáuregui Pérez (1981: 334).

121 Jáuregui Pérez (1981: 433).

122 Jáuregui Pérez (1981: 167).
} 
lo que más me impresionó fue la falta de vida que se advierte en sus habitantes, automatizados por el trabajo constante, rutinario. ${ }^{123}$

A pesar de que ahora ellos manifiestan la añoranza por su terruño, lo describen con buenos recuerdos y piensan que ahí pueden tener una vida feliz y tranquila y consideran a Estados Unidos como un espacio donde las personas tienen una vida automotorizada sin el "verdadero" sentido de vida, no ha sido fácil para muchos migrantes jalostotitlenses regresar a su terruño, dado que tienen que enfrentarse con la distancia física que los separa de su tierra natal y de sus seres queridos y se les dificulta estar en un espacio que les permite anular las experiencias de alienación en la sociedad receptora. Esto es el dilema que los migrantes experimentan. Esto es el "precio" que tuvieron que pagar al cruzar la frontera hacia el Norte en busca del "progreso".

Aquí, la nostalgia y la añoranza por lo que han dejado en el pasado y en su tierra natal que ellos manifiestan, aparecen como una reacción al desarrollo moderno que se basa en el tiempo y el rumbo del desarrollo unilineal. Después de haber realizado el desplazamiento físico hacia Estados Unidos para avanzar hacia el futuro y hacia un mundo con mejor oportunidad de progreso que en su tierra natal ubicado en el mundo rural como espacio de atraso según la idea modernista, los migrantes jalostotitlenses han entrado en el contexto sociocultural, económico, laboral y político de la sociedad receptora en que se enfrentan en su vida cotidiana con la dureza de la realidad y varias experiencias de alienación y han cuestionado el sueño americano y valoran lo que el desarrollo moderno unilineal les hizo dejar atrás. En otras palabras, el desplazamiento físico hacia el Norte en busca del sueño americano ha situado a los individuos en otro contexto sociocultural que transformó el sueño americano como discurso de progreso en el dolor, tristeza, la alienación y la nostalgia.

La nostalgia hacia su tierra natal y el pasado se narra a partir del contraste con los elementos valorados en la idea de desarrollo moderno y los que ahora forman parte de la vida presente de los migrantes y a partir de la revaloración de sus oponentes. Por ejemplo, en la nostalgia, el campo, la tierra natal de México,

123 Jáuregui Pérez (1981: 101). 
las tradiciones y el pasado son elementos altamente valorados, los mismos que fueron marginados en la idea de desarrollo moderno. En cambio, se cuestionan la urbanidad, la abundancia material, la condición de ser empleados asalariados y la vida presente moderna en Estados Unidos, los cuales fueron altamente valorados entre los migrantes antes de salir de su tierra natal.

Los migrantes jalostotitlenses que pasaron su infancia en el rancho o en el centro de la cabecera municipal en los años cuarenta y cincuenta (el período en que aún no era muy notorio el proceso de transición del campo a la ciudad en Jalostotitlán) se fueron a Estados Unidos en busca de un desarrollo moderno. Después de cruzar la frontera, tendieron a dirigirse a zonas urbanas para trabajar y para vivir en busca de un mejor futuro, dado que la ciudad era un espacio de oportunidad y de progreso según la idea de desarrollo moderno. Sin embargo, sus experiencias migratorias en la vida cotidiana en Estados Unidos les hicieron cuestionar el sueño americano y lamentarse por lo que habían dejado atrás al seguir el camino unilineal del desarrollo.

De este contexto surge la nostalgia hacia el campo y hacia Jalostotitlán como un pueblo rural entre los jalostotitlenses. De cierta manera, los ausentes jalostotitlenses de la generación que pasó su infancia antes de la transformación urbana de Jalostotitlán han perdido doblemente su tierra natal como espacio rural: Primero la perdieron emigrando a Estados Unidos y a otras ciudades de México; luego, la perdieron de manera definitiva porque mientras vivían fuera de su lugar de origen, el pueblo se fue transformando en una ciudad y los ranchos de sus familias fueron abandonados y reducidos y desaparecieron por la reducción de personas dedicadas a las actividades ganaderas y agrícolas, por la venta de la tierra, por el reparto entre numerosos hijos y por la urbanización de la cabecera municipal. Por eso, aunque regresan a su tierra natal, ya no pueden encontrar el paisaje de su nostalgia, dado que el verdadero objeto de nostalgia de los migrantes de esta generación es un Jalostotitlán que queda gravado en sus recuerdos de infancia, un Jalostotitlán antes de su transformación en la ciudad. ${ }^{124}$

${ }^{124}$ Renato Rosaldo (1989) denomina como la "nostalgia imperialista" a los sentimientos en los cuales se basan las narrativas de los agentes del imperialismo sobre las tradiciones que se estaban destruyendo por el imperialismo. Esta nostalgia es un sentimiento paradójico 
Hace dos años, fui a mi querido pueblo, a las fiestas del carnaval. Jalos. El Jalos de mis recuerdos ya no es el Jalos de los tiempos actuales. Antes era una aldea sosegada y tranquila...Ahora, la vida pueblerina ya no es como antes [...] Hoy que ha crecido tanto el pueblo las personas, parece como que se inclinan más a lo material que a lo espiritual. ${ }^{125}$

El paisaje material y sociocultural del campo ha desaparecido de tal forma que recuerdan los migrantes jalostotitlenses que pasaron una parte de su vida en el pueblo y en algún rancho de la cabecera municipal antes del proceso de transformación urbana de su terruño. Pero en este proceso de transformación espacial se han construido un imaginario colectivo sobre Jalostotitlán como espacio rural y el apego al paisaje del campo que vive en sus memorias e imaginación. El sentido de pérdida hacia el paisaje rural revive recuerdos y fortalece la añoranza por la tierra de su infancia. Los ausentes hacen presente aquel pueblo rural y aquel rancho, donde vivieron sus familias y pasaron su infancia, en las memorias al hacer una lectura del paisaje material y sociocultural de la actualidad de su tierra natal sintiendo el contraste entre el presente y su pasado.

\section{SURGIMIENTO DE LAS "VACACIONES" DE LOS MIGRANTES}

La transición del campo a la ciudad en el espacio de vida de los migrantes jalostotitlenses en sus lugares de destino en Estados Unidos ha sido un factor fundamental para el cambio en su práctica temporal. Al abandonar el campo como su lugar de trabajo, lograron liberarse del tiempo laboral sujeto al ciclo agrícola e insertarse al calendario laboral urbano. Para los migrantes que fueron empleados para la pizca de productos agrícolas, el período laboral intensivo era la temporada de cosecha. Fuera de esta temporada, por ejemplo, en invierno, no había

porque los sujetos que se lamentan por el cambio y desaparición de las tradiciones que existían antes, fueron quienes participaron de manera directa o indirecta en la expansión del imperialismo. En el caso de los migrantes jalostotitlenses, la formación de su nostalgia hacia el terruño como espacio rural tiene una similitud con la nostalgia imperialista que explica Rosaldo, dado que la migración hacia Estados Unidos en busca del progreso definido en la idea de desarrollo moderno contribuyó de una manera importante a esta doble pérdida del terruño como espacio rural.

125 Jáuregui Pérez (1981: 444). 
suficiente trabajo en el campo para todos los trabajadores que encontraron el empleo para la cosecha. Por esta razón, aquellos migrantes que se dedicaban a la labor del campo y de compañías empacadoras o enlatadoras de frutas y verduras, tenían dificultad de tomar vacaciones y realizar el retorno temporal para asistir a las fiestas patronales de Jalostotitlán que se celebran en agosto.

Sin embargo, al insertarse en el mercado laboral urbano, era relativamente fácil regresar a su tierra natal en agosto aunque no podían estar ahí durante todas las fiestas patronales porque podían estar liberados del trabajo por vacaciones de verano. Además, las fiestas patronales de Jalostotitlán caen en el período vacacional de verano de las escuelas. Gracias a esta coincidencia del período vacacional de verano en los calendarios laboral y escolar en Estados Unidos con las fechas de las fiestas religiosas en el calendario ritual de su lugar de origen, los migrantes jalostotitlenses que viven y trabajan en espacios urbanos han podido regresar a su tierra natal con sus familias en agosto.

Por ejemplo, el migrante jubilado radicado en Norwalk no pudo regresar a Jalostotitlán en agosto de 1953 cuando trabajaba en la pizca de uvas y duraznos en Fresno durante seis meses. Pero, desde que entró a trabajar a una fábrica de fundición en Los Ángeles, el retorno temporal a su tierra natal en agosto ha sido fácil. Ni siquiera tenía que pedir permiso para ausentarse del trabajo a su patrón porque la fábrica estaba cerrada durante tres semanas desde finales de julio hasta mediados de agosto por vacaciones de verano. Cuando comenzaban las vacaciones de verano, se iba con su esposa y sus hijos a Jalos en una camioneta. Después del día 15 de agosto, el día más importante de las fiestas religiosas dedicada a la Virgen de la Asunción, regresaba a California el día 16017 de agosto.

La transición ocupacional del campo a la ciudad no sólo se dio entre los migrantes jalostotitlenses del sur de California, sino entre los migrantes de otra parte de California y de otros estados. Por ejemplo, un migrante jubilado, quien nació en Jalostotitlán en 1932 y ha vivido en Sacramento desde 1955, no podía regresar a su tierra natal cada agosto. Trabajaba desde 1956 a 1982 en una compañía de "canería" (en inglés canery, fábrica enlatadora) de verduras. Para él, 
regresar temporalmente a su tierra natal cada año en agosto era difícil porque las fiestas religiosas de su lugar de origen caían en la temporada de cosecha de espárrago, jitomate y otras verduras. Pero, desde que entró a Coca Cola en 1982, pudo tomar sus vacaciones de verano en agosto y el retorno temporal a su tierra natal en agosto se ha convertido en una práctica anual de su tiempo de ocio de verano.

Un migrante de Maryland, que tenía 68 años en el momento de la entrevista en Jalostotitlán en agosto de 2004, visita Jalostotitlán y la Ciudad de México cada mes de agosto desde 1997. En los años cincuenta, intentó en varias ocasiones cruzar la frontera para trabajar en Estados Unidos. Pero en el primer intento no encontró trabajo y regresó a Jalos. En el segundo intento, se quedó en Mexicali donde trabajó durante cinco meses. En el tercer intento, primero se fue a Sonora, de ahí los contratistas lo llevaron a California. Trabajó durante tres años pizcando jitomates, fresas y lechugas en los campos agrícolas. En los años sesenta cambió su lugar de trabajo a México. Se fue con sus padres y sus hermanos a vivir a la Ciudad de México. Estableció su vida y trabajó como ganadero en Iztapalapa. Pero, a mediados de los años noventa, decidió vender las vacas y tres taxis que tenía porque la urbanización estaba cubriendo el campo de Iztapalapa y pensó que ya no podía seguir trabajando de la ganadería. En 1997, decidió irse a vivir con sus hijos que estaban en Maryland. Ahí consiguió trabajo de medio tiempo en la limpieza de una escuela católica. Este trabajo le permitía tener un largo tiempo de ocio para estar en México porque las vacaciones de la escuela comenzaban a mediados de junio y podía pedir el permiso de su ausencia en el trabajo hasta octubre. De esta manera, anualmente podía estar en Jalostotitlán de julio a finales de septiembre y en la Ciudad de México unos días antes de tomar el vuelo directo a Maryland.

En el trabajo de campo en California, también encontré un caso de un migrante que ha logrado regresar a Jalostotitlán cada agosto articulando el período vacacional en su calendario laboral en California con el calendario ritual de su tierra natal de una manera particular. En 1982, don Severiano llegó con su familia a La Quinta, en el condado de Riverside después de haber trabajado en 
Vallejo, el condado de Saramento, Chicago y Los Ángeles desde 1970. Desde que vivía en Chicago a principio de los años setenta siempre trabajaba como mesero aprovechando su dominio del idioma inglés. Cuando llegó a La Quinta en 1982, se metió a trabajar como mesero en un country club. En el momento de la entrevista realizada en otoño de 2004, también trabajaba como mesero en una instalación. La economía del valle de Coachella, que abarca ciudades como La Quinta, Indio, Palm Spring, etc., depende de más de 200 country clubs, la industria de servicio relacionado con el turismo y la agricultura. ${ }^{126}$ Los country clubs son instalaciones dedicadas a los turistas provenientes de las ciudades del norte del país y de Canadá que llegan a esta región de clima cálido para escapar del frío de sus ciudades y pasan el invierno jugando golf. ${ }^{127}$ Las instalaciones cuentan con casas, campos de golf, restaurantes, gimnasio, espacio para eventos sociales, espacios recreativos, barras, peluquerías, etc. La temporada alta de este turismo comienza en noviembre. Los turistas que tienen membresías en algún country club pasan prácticamente la mitad del año en esta región y se van en junio o julio cuando inicia el verano en sus lugares de residencia.

El calendario laboral sujeto a esta práctica temporal y espacial de los turistas le permitía a este migrante jalostotitlense regresar a su tierra natal cada agosto. De hecho, desde que vivía en La Quinta podía estar siempre en Jalostotitlán en temporada de fiestas religiosas locales con una sola excepción: agosto de 1999, dado que en ese año tuvo que permanecer en el país para recibir la ciudadanía estadounidense en ese mes. La manera en que él podía asegurar sus vacaciones de verano para regresar a su tierra natal en agosto era lo siguiente: Al comenzar el verano, los miembros del country club se iban a sus lugares de origen. Cuando el número de los clientes del restaurante de la instalación disminuía, la

${ }^{126}$ La Quinta subió a la categoría de ciudad del condado de Riverside en 1982, debido al rápido crecimiento demográfico por el desarrollo de turismo. Según el censo de 2000, 32.01 por ciento de la población eran hispanos (Census 2000).

${ }^{127}$ Se dicen "snowbirds" tourists para referirse a estos turistas procedentes de Canadá y del norte de Estados Unidos que viajan a lugares con el clima cálido para escapar del largo invierno de sus lugares de residencia. Por lo general, son jubilados y propietarios de empresas que tienen disponibilidad de tiempo y de recursos económicos para estar lejos de sus lugares de residencia y para poder comprar membresía costosa del country club. 
administración tenía que minimizar el número de trabajadores. Entonces, él tomaba sus vacaciones de verano.

Hay otros factores importantes que les permitieron a los migrantes jalostotitlenses que se insertaron en el mercado laboral urbano realizar el retorno temporal cada año. En primer lugar, aunque muchos de ellos iniciaron su vida migratoria como indocumentados, lograron legalizar su estatus migratorios al tener hijos nacidos en Estados Unidos o al recibir documentos necesarios de parte de sus patrones para realizar el trámite de la visa. De hecho, la mayoría de mis entrevistados contaban con su residencia permanente en Estados Unidos cuando regresaban anualmente a Jalostotitlán en los años sesenta y los años setenta. Incluso, muchos de los migrantes jubilados ya obtuvieron ciudadanía estadounidense hasta finales de los años noventa. Este mejoramiento en el estatus legal les ha permitido moverse de Estados Unidos a México y volver al Norte sin problema ni costos y riesgos altos en el cruce fronterizo.

En segundo lugar, al vivir y trabajar en Estados Unidos con el estatus migratorio legal, han establecido su vida en la sociedad receptora, lo cual les ha permitido regresar a las mismas localidades y los mismos trabajos que antes de regresar temporalmente a su tierra natal. Para los migrantes legales, el retorno temporal no ha significado la suspensión de su vida migratoria, dado que salen del trabajo y del país en su tiempo de ocio y siguen con los mismos proyectos de vida y de trabajo al regresar de México. En este sentido, hay circularidad en la migración jalostotitlense hacia Estados Unidos a pesar de su establecimiento en ese país. Pero este movimiento poblacional es diferente de la migración circular del período del Programa Bracero en el cual los migrantes se iban a trabajar a Estados Unidos y regresaban a México en el fin de la temporada de producción agrícola perdiendo el trabajo. La forma dominante del movimiento circular entre los migrantes jalostotilenses legales es vivir en Estados Unidos teniendo sus propias casas, familias y trabajos estables, regresar a su tierra natal en vacaciones y luego, volver a la vida que tienen en el Norte cuando termina su tiempo de ocio.

Por el otro lado, aunque han podido estar en Jalostotitlán cada agosto, para aquellos migrantes de edad económicamente productiva que cuentan con trabajo 
estable en Estados Unidos, ha sido difícil regresar a su tierra natal para celebrar el carnaval porque las fechas de esta festividad no caen en el período vacacional laboral. La mayoría de los migrantes que viajan a Jalostotitlán para el carnaval cada año son los migrantes jubilados y los migrantes jóvenes solteros que aún no buscan el establecimiento laboral y de vida en ese país o que tienen facilidad de pedir permiso de descansar en un tiempo corto a sus patrones de trabajo, quienes son también originarios de Jalostotitlán.

En la temporada de fiestas patronales de agosto, la cabecera municipal recibe a miles de jalostotitlenses radicados en Estados Unidos que regresan con sus familias. Por ejemplo, en el día 16 de agosto de 2003, se repartieron alrededor de 1,900 calcomanías del día de los hijos ausentes para los jalostotitlenses procedentes de Estados Unidos y otros lugares de la República Mexicana quienes participaron en la peregrinación y la misa dedicadas a los hijos ausentes. Aunque en este evento no participaban todos los ausentes que llegaron a Jalostotitlán durante las fiestas de agosto porque había migrantes que se fueron a las playas o regresaron antes de esta fecha a Estados Unidos, los migrantes de Estados Unidos formaban la mayor parte de los peregrinos. En el carnaval, llegan alrededor de 10,000 visitantes a la cabecera municipal según lo que estima la presidencia municipal a partir de los datos de la venta de boletos de entrada de algunos eventos realizados en el carnaval. Aunque Jalostotitlán recibe a un gran número de visitantes que llegan de localidades vecinas del municipio y de otros lugares de los Altos de Jalisco, la presencia de los migrantes de Estados Unidos también es fuerte en esta festividad local de Jalostotitlán.

Según los habitantes de la cabecera municipal, desde que comenzó la migración masiva hacia Estados Unidos, siempre había el retorno temporal de migrantes en temporada de fiestas locales, pero desde la segunda mitad de los años ochenta, la presencia de los ausentes de Estados Unidos se ha vuelto mucho más notoria durante las fiestas patronales y el carnaval.

La razón por la cual el retorno temporal de los jalostotitlenses radicados en Estados Unidos se ha convertido en un fenómeno masivos a partir de la segunda mitad de los años ochenta, tiene que ver con el impacto de la legislación de 
Immigration Reform and Control Act (IRCA), conocida como la ley SimpsonRodino en 1986, la cual permitió la legalización de la residencia en Estados Unidos de 2,300,000 migrantes mexicanos. ${ }^{128}$ Gracias al beneficio de esta reforma migratoria estadounidense, muchos migrantes que habían entrado al país del norte en las décadas anteriores obtuvieron su estancia migratoria legal.

Los migrantes, que salieron hacia Estados Unidos de forma masiva desde los años sesenta y se establecieron como forma de vida en los lugares de destino, ahora pueden regresar a su lugar de origen con facilidad, gracias a su nuevo estatus migratorio. Además, pueden hacerlo junto con sus esposas e hijos nacidos o crecidos en los Estados Unidos. A pesar de que el propósito de la ley era frenar la migración indocumentada, después de la legislación de esta ley migratoria, no disminuyó el flujo de migrantes jalostotitlenses sin papeles. Al contrario, aumentó el número de los migrantes sin papeles debido a la crisis económica de México y porque dejaron su tierra natal para dirigirse al Norte con el fin de recibir, de alguna manera, el beneficio de esta ley migratoria. Por la antigüedad de la tradición migratoria, la nueva generación de jóvenes migrantes puede conseguir más fácilmente estatus legal o el apoyo económico para pagar "polleros" y encontrar trabajo y hospedaje. Los nuevos migrantes que pudieron arreglar papeles también han participado en las corrientes masivas que se dirigen a su lugar de origen en temporada de fiestas.

Además, después de la segunda mitad de los años ochenta, la migración jalostotitlense sigue manteniendo la tendencia que comenzó a surgir en los años sesenta y setenta a ser la migración familiar que dirige a las zonas urbanas más que los campos agrícolas. Al vivir y trabajar en las ciudades, los migrantes han tenido más facilidad de articular el periodo vacacional en el calendario laboral con el calendario escolar de sus hijos y el calendario ritual de su tierra natal para regresar con sus familias para las fiestas locales de agosto.

Además de estos cambios en el patrón migratorio, la edad de los hijos de los migrantes jalostotitlenses que habían salido a Estados Unidos de forma masiva en

${ }^{128}$ González de la Rocha y Escobar Latapí (1990) analizan el impacto de esta reforma migratoria en patrones migratorios a partir de los resultados de investigaciones cuantitativas realizadas en el municipio de Jalostotitlán. 
las décadas anteriores ha influido en el aumento de los "hijos ausentes" radicados en Estados Unidos que regresaban temporalmente a Jalostotitlán. Los ausentes de la segunda generación nacida en los años sesenta y setenta ya eran de mayor edad o estaban en la adolescencia a finales de los años ochenta. Las fiestas de la tierra natal de sus padres les han atraído a los jóvenes ausentes porque Jalostotitlán les ofrece sitios y eventos para tener noviazgo y para divertirse con sus amigos y parejas sin preocuparse tanto de la edad y de las normas sociales, como en Estados Unidos. En los años noventa y la actual década del siglo XXI, se han incorporado a los flujos de los migrantes de primera generación que regresan a Jalostotitlán para las fiestas, los ausentes de segunda generación que se casaron con personas originarias de la tierra natal de sus padres y ahora regresan con sus nuevas familias y los ausentes solteros que viajan con sus primos y amigos a Jalostotitlán para pasar las vacaciones buscando noviazgo y diversión.

Como expliqué en el capítulo 2, hay varios motivos por los cuales los migrantes y sus familias radicados en Estados Unidos desean regresar a Jalostotitlán en temporada de fiestas locales de Jalostotitlán. En primer lugar, las fiestas son una oportunidad importante para el reencuentro entre miembros de una familia extensa, novios y amigos para renovar los lazos con las personas que se encuentran en diferentes lugares de México y Estados Unidos. En segundo lugar, en el caso de las fiestas de agosto, la devoción por la Virgen de la Asunción y la reafirmación de su identidad religiosa a través de la participación en los ritos son un motivo fundamental. Pero la cuestión religiosa no es el único motivo del retorno temporal. Tanto en las fiestas patronales de agosto como en el carnaval, el tiempo y el espacio ritual de Jalostotitlán también les ofrecen a los ausentes oportunidades para experimentar una liberación de la cotidianeidad sujeta al trabajo y normas sociales estrictas en los asentamientos y estilos de vida diferentes de lo que tienen en Estados Unidos, sentir el cambio efímero en su estatus social y refortalecer el sentido de pertenencia a Jalostotitlán.

También es importante entender los motivos del retorno temporal en términos de diferencia de edad y en la etapa de vida. Por ejemplo, para los migrantes solteros y los jóvenes de la segunda generación, ver a sus novias y buscarlas en 
Jalostotitlán y sentir el cambio en su estatus social y la libertad a través de su capacidad de consumo en las fiestas son motivos dominantes. Para los migrantes en edad económicamente activa que regresan con sus esposas e hijos, la transmisión de tradiciones y costumbres del lugar y del país de origen a sus hijos nacidos y crecidos en Estados Unidos es un motivo importante. Para los migrantes jubilados, Jalostotitlán es un espacio donde pueden liberarse de las experiencias de alienación y soledad en su vida jubilada en Estados Unidos, tener más actividades y transformarse en seres revalorados y respetados socialmente.

En realidad, las familias migrantes radicadas en Estados Unidos no planean sus proyectos vacacionales de retorno temporal a las fiestas locales (en especial a las fiestas religiosas de agosto) por un motivo único. Al determinar sus itinerarios de viaje a Jalos, los migrantes jalostotitlenses combinan diferentes motivos de sus miembros para poder involucrar a cónyuges, hijos y nietos en el viaje de retorno. Algunas familias migrantes llegan de Estados Unidos a Guadalajara en avión, de ahí viajan a Jalostotitlán en autobús, taxi o coches de algunos parientes. Otros viajan en autobús o en camioneta a su tierra natal. Pero, entre las familias migrantes, es muy común incluir en su plan de retorno temporal a Jalostotitlán viajes a otros lugares de México, tales como, Puerto Vallarta, Acapulco, Cancún, Guanajuato, Aguascalientes, Guadalajara, Ciudad de México, Zacatecas, Tijuana para visitar a sus familiares o para hacer turismo, dado que no todos los miembros de la familia quieren viajar solamente a Jalostotitlán cada año, y dado que tampoco comparten el mismo apego a Jalostotitlán que tienen los migrantes de la primera generación. En el caso de que los migrantes jalostotitlenses estén casados con personas originarias de otros lugares de México, los lugares de origen de sus cónyuges también se incluyen en sus itinerarios de retorno a México.

Los gastos de viaje varían dependiendo de su estatus migratorio, itinerario de viaje, el número de las personas que viajan juntos y los medios de transporte. Pero, por lo general, un migrante legal gasta alrededor de 2,000 dólares para viajar solo. En cambio, un migrante sin papeles gasta entre 5,000 y 6,000 dólares porque necesita pagar 3,000 dólares a un "coyote" para el viaje de regreso a Estados Unidos. Pero si viaja con su familia, gasta alrededor de 5,000 dólares. 
En la cabecera municipal sólo existen tres hoteles. Obviamente esta infraestructura de turismo en Jalostotitlán no tiene capacidad para hacer una oferta suficiente a los miles de jalostotitlenses que llegan de Estados Unidos y de otros lugares de México. Pero las casas de los familiares y las casas construidas y ampliadas por la inversión de migradólares se utilizan como hospedaje de estos visitantes en temporada de fiestas locales.

Cabe destacar que el retorno temporal masivo sustentado por diversos motivos no sólo se realiza en el tiempo ritual, sino también en el tiempo de ocio que se ha establecido en la vida de los migrantes. Por lo tanto, las actividades que ellos esperan tener durante la estancia en su terruño no sólo reflejan los significados que dan a las fiestas locales como rituales, sino que también se caracterizan por el tiempo de ocio que tiene su propia lógica. En el tiempo efímero liberado del trabajo se construye una cotidianeidad opuesta a las condiciones prevalecientes en el mundo del trabajo, en la cual los individuos intentan tener actividades, roles y posiciones sociales, estilos de vida y experiencias diferentes de los que tienen en la vida cotidiana sujeta al trabajo (Hiernaux, 2000). En el caso de los migrantes jalostotitlenses, el mundo del trabajo del cual se liberan durante las vacaciones a través del retorno temporal a su terruño, es Estados Unidos donde experimentan la alienación en distintas formas. Como expliqué en el capítulo 2, a partir de estas experiencias de alineación en ese país, se forma la nostalgia hacia el terruño como "tierra prometida" para estar libre de la insatisfacción de su vida cotidiana. Ahora, al establecer en sus vidas el tiempo de ocio en temporada de las fiestas de su terruño, han encontrado la forma de anular la alienación en el tiempo y espacio de ocio y ritual, es decir, en el exterior de la cotidianeidad de Estados Unidos visto como espacio de trabajo y han logrado realizar sus sueños del retorno aunque sea de manera temporal.

Debido a que se lleva a cabo el proyecto del retorno temporal en el tiempo de ocio, no es sorprendente que esta práctica espacial de los migrantes se entrecruza con las rutas del turismo masivo y que algunas expectativas de los migrantes sobre el retorno temporal (como las experiencias de tener estilos de vida rural y de sentir un cambio en su estatus social, la compra de los productos que llevan 
símbolos de Jalostotitlán) están relacionadas estrechamente con el consumo, el acto que se opone a la producción. ${ }^{129}$

Además, a través de esta nueva práctica espacial de los migrantes en sus vacaciones, se creó el contexto en que el terruño como espacio físico hace el contacto con los terruños imaginarios colectivos de los migrantes y entra en un nuevo proceso de transformación local. Como explicaré en el siguiente apartado, los actores locales se apropian de la nostalgia de los migrantes hacia el espacio rural y contribuyen al reestreno del ambiente del "pueblo rural" en las escenas festivas de Jalostotitlán.

\section{REESTRENO DEL PUEBLO RURAL}

La consolidación del "tiempo de ocio" que les permite a miles de migrantes realizar el retorno temporal a su tierra natal, inició una nueva transformación de Jalostotitlán que se caracteriza por la materialización del imaginario colectivo del pueblo rural. Sin embargo, el paisaje rural no se materializa ni se representa en Jalostotitlán durante las fiestas locales de la misma manera como había existido antes de la transformación urbana de Jalostotitlán. La dureza de la vida, la pobreza en el campo y otros aspectos oscuros de la vida tradicional en el campo y en el pueblo no forman parte del nuevo paisaje rural de Jalostotitlán. Los casos etnográficos que se presentan en este apartado ilustran que el paisaje del campo y del pueblo que se representa (incluso se presenta y se consume) es un espacio lúdico y un estilo de vida para pasar el tiempo de ocio tanto para los ausentes como para los habitantes de la cabecera municipal.

\section{1) Sombrero como signo del estilo de vida "ranchera"}

Desde que comenzó el retorno temporal masivo de los migrantes en la segunda mitad de los años ochenta, se han abierto varias tiendas, restaurantes, bares y discotecas que les ofrecen productos y servicios tanto a los habitantes como a los visitantes. De hecho, como demuestra la gráfica 1, el comercio y el

${ }^{129}$ Explicaré de manera detallada el consumo de los migrantes en retorno temporal en un apartado del capítulo 5. 
servicio son dos de los sectores laborales que han demostrado un incremento significativo en el número de las personas de edad económicamente activa en el nivel municipal en las últimas dos décadas. Muchos de estos nuevos negocios comerciales de la cabecera municipal buscan una mayor ganancia en temporada de fiestas locales.

La tienda de sombreros Country Hats era uno de estos negocios que vendían más productos en temporada de fiestas locales a la llegada de los visitantes a Jalostotitlán que en la temporada baja. ${ }^{130}$ La tienda tenía tres tipos de clientes: en primer lugar, las personas que se dedican a labores agrícolas y ganaderas en Jalostotitlán compraban sombreros para el trabajo y para montar a caballo y otros para salir los domingos; en segundo lugar, los habitantes que no trabajan en el campo también compraban sombreros; la tercera categoría de clientes era los hombres que llegaban de Estados Unidos. Los ausentes que retornaban de Estados Unidos compraban normalmente 4 o 5 sombreros como regalos porque sabían que los mismos productos costaban en ese país entre 200 y 600 dólares. Los productos que se vendían eran sombreros para el trabajo agrícola que costaba alrededor de 150 pesos, sombreros para salir que costaba alrededor de 450 pesos, sombreros de modelos diseñados para jóvenes, botas, camisas, playeras de Jalos y del carnaval como artículos de recuerdo de las fiestas. Febrero y agosto son los meses en que se vendían más sombreros, es decir, los meses que se celebran el carnaval y las fiestas patronales en Jalostotitlán.

El sombrero es un signo del campo que tanto los habitantes como los ausentes llevan durante el carnaval para ir a charreadas y corridas de toros. En el carnaval también se celebran otros eventos que evocan la imagen de campo. En el palenque se organizan peleas de gallos y conciertos de cantantes de música ranchera, la exposición ganadera, etc. Pero, los que se llevan sombreros y los que van a estos eventos que evocan la rusticidad arraigada en la vida ranchera no sólo son los ausentes, sino los habitantes de la cabecera municipal. En febrero de 2005, fui por primera vez en mi vida a una corrida de toros. Me acompañaron a la plaza

${ }^{130}$ Realicé la entrevista en esta tienda en agosto de 2004. Pero, dos años después, descubrí que el negocio se traspasó a otra persona. Ahora, en el local está una tienda que vende otros productos. 
de toros mis amigos que trabajan como profesionistas en Jalostotitlán. Al verlos con sus sombreros y una cantimplora de piel que tenía tequila, me sorprendió su apariencia, dado que jamás los había visto con sombreros desde que los conocí en el año 2003. El contraste entre sus sombreros de ese día y la vida profesional que ellos tenían en su vida cotidiana me hizo reír. Uno de ellos me explicó que sólo cuando iba a corridas de toros, se disfrazaba de "ranchero".

Estas descripciones etnográficas de sombreros ilustran que estos objetos que se han usado tradicionalmente para realizar labores en el campo, ahora también se usan y se venden como signo del estilo de vida "ranchera" en temporada de fiestas locales. Tanto para los retornados temporales como para la mayoría de los habitantes, el estilo de vida "ranchera" que se representa en estos objetos no es un estilo de vida arraigado en sus actividades laborales y sociales en su vida cotidiana, sino un estilo de vida tradicional idealizado, un símbolo del terruño o un disfraz para actividades recreativas en su tiempo de ocio aunque todavía existen personas dedicadas a labores agrícolas y ganaderas, quienes usan sombreros como "uniforme" de su trabajo.

\section{2) Ambiente del espacio rural mercantilizado}

El estilo de vida "ranchera" no sólo se representa en objetos, sino que también se mercantiliza como servicio para las fiestas. En un día de febrero de 2004, don Francisco Javier Reynoso Gutiérrez, quien regresó a Jalostotitlán de manera definitiva en 1983 después de haber vivido en California durante 20 años, me invitó a ir a su bodega que se estaba remodelando para abrir un salón de fiestas. El salón tiene capacidad para aproximadamente 800 personas. Cuando fui a la bodega, los albañiles estaban remodelando su interior con adobe y ladrillo para crear un estilo rústico, que asemejara a una casa tradicional de rancho. Estaban construyendo la fachada de una casa de adobe en la esquina de la bodega para recrear la casa de rancho de su abuelo. Me comentó don Francisco que su casa de rancho ya no existía porque su familia había vendido el rancho hace tiempo. Escogió este estilo para el salón de fiestas porque la mayoría de los jalostotitlenses también tenían o vivían en ranchos antes de que Jalostotitlán 
creciera tanto y compartían el gusto por la vida ranchera y las casas rústicas. Ya sólo faltaban dos meses para concluir la remodelación. Agosto y febrero serían la época en que tendría más renta el salón porque muchos preferían organizar las ceremonias religiosas y fiestas sociales en temporada de fiestas locales de Jalostotitlán cuando se reunían en Jalos los familiares de México y de Estados Unidos. Su salón de fiesta se llamaría "Casa Grande".

La imagen del rancho que se representa en este salón de fiestas se construyó a partir de las experiencias y las memorias de este ex-migrante de la vida en el rancho de su familia y la añoranza por el estilo de vida rural que perdió por la venta del rancho en el proceso de urbanización de su terruño y por haber emigrado a Estados Unidos. Pero al recrear la casa del rancho de su abuelo como aspecto que diferencia a su negocio de otros salones de fiesta, este ex-migrante sabía que el sentido de pérdida del hogar en el espacio rural y la añoranza no sólo son sentimientos personales, sino que son sentimientos y el gusto que comparten los demás habitantes y los jalostotitlenses que viven fuera de esta localidad. La "Casa Grande" es una casa de rancho construido encima de la zona urbana. Es un hogar rústico que se asocia con la alegría, el calor humano y la imagen del espacio gregario, con los cuales llenarían la bodega los jalostotitlenteses al usar este salón para celebrar las fiestas familiares en el mes de febrero y agosto, la temporada en que se reúnen en Jalostotitlán los miembros de familia y parientes radicados en distintos lugares de México y Estados Unidos.

\section{3) Paseo al campo}

Tanto para los jalostotitlenses radicados en otras ciudades de México y Estados Unidos como para muchos de los habitantes de Jalostotitlán que ya no se dedican a labores agrícolas y ganaderas, los ranchos que aún quedan en menor escala que en las décadas anteriores en los suburbios de la ciudad, no son espacios que se usan en su vida cotidiana, sino terrenos destinados para pasar el tiempo de ocio con sus familias y amigos.

En agosto, en un día de fiestas, la mayoría de los habitantes de la cabecera municipal van a algún rancho de la familia que se encuentra en el suburbio de la 
cabecera municipal para convivir tanto con sus familias y parientes que viven en Jalostotitlán como con los que llegan de Estados Unidos y otros lugares de México. Se van de la ciudad en camionetas llenas de familiares y amigos. En el rancho, comen barbacoa, carnitas o carne asada y otros platillos. Ahí pasan toda la tarde hasta oscurecer, los adultos, platicando, tomando cervezas o tequila con sus familiares y amigos, los niños jugando con sus primos.

Desde que las familias se han asentado en el centro de Jalostotitlán, el paseo al campo se ha transformado en una tradición del mes de agosto. Antes de que la parroquia organizara el llamado "paseo del pueblo", cada familia se iba de paseo al rancho. Pero, posteriormente, en el proceso de transición del campo a la ciudad en Jalostotitlán, la parroquia organizaba el día 17 de agosto un paseo al campo para hacer convivencia con todos los habitantes de Jalostotitlán. En mi trabajo de campo, muchos habitantes y ausentes de Jalos comentaban sus gratos recuerdos del "paseo del pueblo" que organizaba la parroquia el día 17 de agosto. En ese día la ciudad se quedaba vacía. Pero, este paseo del pueblo organizado por la parroquia se suspendió hace tiempo. Ahora, cada familia organiza su paseo como antes.

Lo interesante de este caso es que la iglesia local se apropió de las prácticas de los habitantes de pasar el día de descanso en los ranchos en el proceso de urbanización de la localidad y estableció un evento para crear el ambiente del "pueblo", y que después de la suspensión de este evento organizado por la parroquia, los jalostotitlenses revivieron las prácticas que existían antes en Jalostotitlán para usar en el tiempo de ocio los terrenos agrícolas que aún quedan en los suburbios de la ciudad en forma reducidas. ${ }^{131}$

4) Apropiación de la imagen del espacio rural y la presentación oficial de Jalostotitlán como pueblo rural

${ }^{131}$ El "paseo del pueblo" terminó en Jalostotitlán. Pero en las fiestas de la Virgen de la Asunción organizadas en California, se llevó al cabo un evento llamado "paseo del pueblo" el 17 de agosto de 2003 en el parque de South Gate, en el condado de Los Ángeles. Véase el capítulo 4 de esta tesis. 
En las prácticas comerciales y sociales de los jalostotitlenses que describí anteriormente, se puede observar que la rusticidad que se representa, se presenta, se practica y se consume es una imagen del campo como espacio lúdico y un estilo de vida rural para pasar el tiempo de ocio. Sin embargo, la imagen de Jalostotitlán como espacio rural lúdico no sólo se representa en los objetos, servicios y en las actividades recreativas. Más bien, en los años recientes, esta imagen ha sido apropiada como la imagen oficial para la presentación de la ciudad hacia el exterior.

En los folletos de las fiestas locales, los discursos de los conductores de los eventos y las revistas y los libros publicados en Jalostotitlán es muy común usar la palabra "pueblo" para referirse a la localidad aunque oficialmente está definida como "ciudad". Por ejemplo, en un programa de la radio de Guadalajara titulado, "Tierra de mis amores", se hizo la presentación del municipio de Jalostotitlán en 2001. En el programa, el cronista Luis Jesús Ramírez Jiménez comentó que aunque Jalostotitlán ahora es una ciudad, los habitantes de Jalostotitlán quisieran denominarlo "pueblo", en donde la gente se caracteriza por su amabilidad, hospitalidad y actitud abierta hacia las personas que vienen de fuera.

Esta imagen de los jalostotitlenses también se observa en las frases de los folletos turísticos producidos por el gobierno municipal:

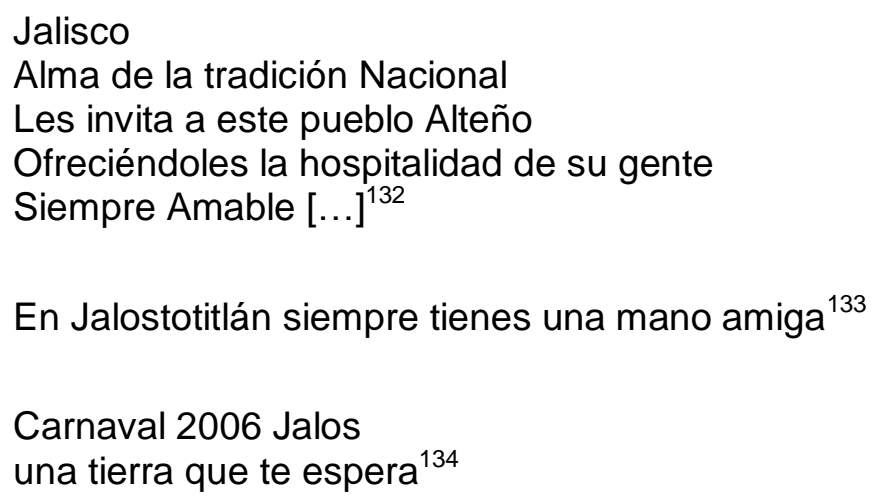

${ }^{132}$ Folleto turístico que conseguí en la presidencia municipal de Jalostotitlán en agosto de 2002.

${ }^{133}$ Otro folleto turístico que conseguí en la presidencia municipal de Jalostotitlán en agosto de 2002.

${ }^{134}$ El folleto del carnaval de Jalostotitlán del año 2006. 
La imagen del "pueblo" y de sus habitantes que se representa de este modo es diferente de las características históricas y estereotipos sobre las comunidades campesinas tradicionales de provincias mexicanas que se describen por lo general como comunidades campesinas cerradas hacia el mundo exterior. ${ }^{135}$ De hecho, durante el trabajo de campo y mi estancia en la Ciudad de México, uno de los estereotipos que me comentaron de los Altos de Jalisco las personas que no son originarias de esta región fue que los pueblos de esta región y sus habitantes no son tan abiertos como en otros lugares de México. Para justificar esta imagen, señalaron las características de la formación histórica de ranchos y la guerra cristera. Pero algunos de los que tenían este estereotipo se sorprendieron por la actitud abierta de los jalostotitlenses hacia ellos durante su estancia en Jalostotitlán.

La creación del paisaje del pueblo rural ahora es un proyecto municipal. En el año 2004 inició el proyecto de la promoción turística "Ven a Jalos". Lo que busca este proyecto es traer a la cabecera municipal a una parte del gran número de turistas que hacen el recorrido de turismo religioso entre San Juan de los Lagos y Santa Ana de Guadalupe. Este proyecto está relacionado estrechamente con el proyecto regional turístico de la Secretaría de Turismo del gobierno del estado de Jalisco. En la ruta cristera que se promueve en este proyecto, Jalostotitlán se ubica entre Santa Ana de Guadalupe y San Juan de los Lagos, dos lugares importantes del turismo religioso. ${ }^{136}$ Por lo tanto, Jalos no se puede presentar como otro destino del turismo religioso, sino que debe de proponer otro tipo de turismo. Lo que se propone en este proyecto de turismo en Jalos es la arquitectura de estilo rústico de la ciudad. Desde el febrero de 2004 ya había comenzado un proyecto piloto de la remodelación del centro histórico. Con la colaboración del ayuntamiento, la Secretaría de Turismo del gobierno del estado de Jalisco y los propietarios de las casas antiguas ubicadas en el centro, se pintaron las fachadas

${ }^{135}$ Véase el concepto de "comunidad campesina corporativa cerrada" que propone Wolf (1957).

${ }^{136}$ Santa Ana de Guadalupe es una ranchería perteneciente al municipio de Jalostotitlán. Después de la canonización de los mártires de la guerra cristera en el año 2000, este lugar se convirtió en el destino de miles de peregrinos que piden y pagan la manda al Santo Toribio Romo, uno de los nuevos santos mexicanos. Explicaré esta peregrinación en Santa Ana de Guadalupe en el capítulo 4 de esta tesis. 
de algunas casas. Para dar una apariencia rústica a las casas, se seleccionaron, por la recomendación del Instituto Nacional de Antropología e Historia, tres colores: ocre, tierra y terracota.

Estas imágenes del "pueblo" que se representan en el comentario del cronista en el programa de la radio, en los folletos turísticos y en el proyecto local de turismo, no necesariamente está dirigida a los habitantes de Jalostotitlán. Más bien, está diseñada y dirigida hacia las miradas de aquellas personas que no viven en esta localidad para promover la visita. Aquí, el ambiente del "pueblo rural" no se narra como una comunidad campesina cerrada para el mundo exterior, sino que se representa y se presenta a los visitantes que viajan a Jalostotitlán en su tiempo de ocio como un lugar que conserva las casas de estilo arquitectónico rústico y donde habita gente con amabilidad, hospitalidad y actitud abierta.

El pueblo rural como objeto de la nostalgia de los jalostotitlenses que surgió del proceso de transición del campo a la ciudad en Jalostotitlán y del contraste entre los recuerdos de los migrantes sobre la vida en el campo y sobre el estilo de vida tradicional rural y el presente urbano moderno extranjero, ahora se ha convertido en un lugar imaginario popular como un espacio lúdico que viven los jalostotitlenses en vacaciones y en el tiempo ritual. La nueva vida ranchera no es un espacio que se presenta a través de los recuerdos de la pobreza y la dificultad de la vida que realmente existían, sino que se imagina, se recuerda, se presenta y se consume con la grata sensación del pueblo imaginario idealizado, lleno de alegría, calor humano, la convivencia con seres queridos, y cercanía con la naturaleza por medio de la participación en charreadas, corridas de toros, peleas de gallos, la melodía de la música ranchera, el consumo de sombreros y botas, el paseo al campo y las casas de estilo arquitectónico tradicional.

Aquí se observa una ruptura de significados del pueblo y del rancho. Antes de la urbanización de la localidad de Jalostotitlán, este lugar era un pueblo pequeño que contaba con una menor población que en los ranchos. El primer significado del término "pueblo" es de la definición de este Jalostotitlán del pasado. El segundo significado de esta palabra es de uso folklórico. A pesar de la 
urbanización de este lugar, los jalostotitlenses siguen llamando a esta ciudad "pueblo" como un término folklórico para referirse a la tierra natal que contrasta con otras ciudades más grandes donde viven muchos de los jalostotitlenses que radican fuera de esta localidad. El tercero significado es que como ilustran los casos etnográficos que presenté en este apartado, el "pueblo" es un término usado como tropo o símbolo dominante que regula la imaginación popular sobre Jalostotitlán en el proceso reciente de transformación de esta localidad en que se representa el ambiente rústico en la ciudad durante las fiestas locales. ${ }^{137}$ En este uso del término "pueblo", se hace una ruptura con el primer significado, dado que a lo que se refiere esta palabra no es la definición estricta de la localidad en el sentido demográfico y geográfico, sino la imagen del espacio rural lúdico que se proyecta en la ciudad.

En el caso de la palabra "rancho", el significado original de este término es el espacio que habitaba la mayor parte de las familias jalostotitlenses como unidad social formada desde la época colonial y dedicada a la producción agrícola y ganadera. Asimismo, el rancho fue un elemento fundamental para la formación histórica de una identidad regional asociada con la autonomía y la convivencia con la naturaleza y la ganadería. Pero en el contexto en que comenzó el proceso de urbanización de Jalostotitlán y surgió el auge de la migración hacia Estados Unidos, este término adquirió un nuevo significado: un espacio de atraso que contrastaba con la ciudad vista como espacio de progreso. Sin embargo, en la nueva transformación de Jalostotitlán, hay una ruptura con los significados que los jalostotitlenses habían dado a este término históricamente. Ahora el "rancho" se convierte en una palabra que tiene una connotación positiva. Aunque algunos habitantes siguen usando esos terrenos agrícolas para la producción agrícola y ganadera, la mayoría de los habitantes los usan para pasar el tiempo de ocio con sus familias. El "rancho" es una palabra que evoca fuertemente en aquellos

137 Jennifer Robertson (1991) explora el proceso de transformación de una localidad suburbana de Tokio, enfocándose en el término furusato (literalmente significa villa antigua o terruño) que se usa como tropo en el proyecto de reconstrucción cultural tanto en nivel nacional como en nivel local. Mi idea de analizar el término "pueblo" y "rancho" como tropos dominantes que regulan la imaginación popular sobre la rusticidad mexicana fue inspirada por su investigación etnográfica. 
jalostotitlenses, que viven y trabajan en zonas urbanas de esta localidad y de otras, la imagen del espacio rural, del espacio de libertad, del espacio lúdico, del estilo de vida independiente y de un modo de vida tradicional idealizado que contrasta con su vida cotidiana. Igual que el término "pueblo", la palabra "rancho" es un tropo dominante que regula la imaginación sobre la rusticidad local durante las festividades locales.

En este sentido, lo que se materializa en las escenas festivas de Jalostotitlán no son las imágenes del espacio rural que existió realmente en el pasado. El reestreno del "pueblo rural" no es la restauración del paisaje del pueblo de Jalostotitlán que existió antes de la urbanización. Lo que se materializa y se reestrena son las imágenes idealizadas del pueblo y ranchos, construidas a partir de las memorias, la imaginación y las expectativas de las vacaciones. Son un espacio rural imaginario, y la ficción y el "simulacro" del pueblo y ranchos que operan sobre la realidad de Jalostotitlán y crean una "hiperrealidad" a través de una serie de signos del campo representados en objetos, servicios, eventos, vestidos, actividades recreativas, discursos y el estilo arquitectónico de las casas antiguas del centro histórico.

\section{CONCLUSIONES}

En este capítulo, he descrito tres momentos de la transformación de Jalostotitlán: el primer momento de la transformación es la construcción histórica de la localidad como una sociedad rural desarrollada desde la época colonial. El Jalostotitlán de este momento se entiende como un espacio rural que se componía del pueblo pequeño y de los ranchos habitados por una mayor población; el segundo momento de la transformación de esta localidad es la transición del espacio rural al urbano. En este proceso de transformación que se dio en forma paralela al proceso migratorio internacional que había comenzado a principios del siglo XX, Jalostotitlán se convirtió en una ciudad; en el tercer momento de la transformación de esta localidad, Jalostotitlán se ha reconstruido como una ciudad donde se reestrena el ambiente del "pueblo rural" desde que el retorno temporal 
de los jalostotitlenses radicados en Estados Unidos se ha convertido en un fenómeno social anual desde la segunda mitad de los años ochenta.

Lo que intenté en este capítulo a través de revisar brevemente estos tres momentos de la transformación de Jalostotitlán, fue entender cómo Jalostotitlán ha entrado en el proceso actual de reconstrucción de esta localidad después de haber pasado dos momentos anteriores de la transformación y en qué tipo de lugar se está transformando en el tercer momento. Para ello, me enfoqué en la articulación de algunos procesos que se han dado en la sociedad receptora de los migrantes y otros que atraviesan la frontera con Estados Unidos con los procesos de transformación de Jalostotitlán. Lo que quise enfatizar al enfocarme en la articulación de distintos procesos, fue que para entender la reconstrucción de la localidad de origen de los migrantes, es importante no analizar sólo los procesos que se dan dentro de los territorios locales, sino también la relación entre estos procesos locales y otros procesos que se dan en otros lugares y se articulan con los primeros de manera transnacional. Con esta idea, pretendí describir cómo han surgido y se han desarrollado los procesos locales de transformación de Jalostotitlán a través del vínculo con los procesos transnacionales.

Lo primero que pretendí explorar a través de esta aproximación analítica, fue la formación de la nostalgia hacia Jalostotitlán que los migrantes narran a través de las imágenes rústicas. En el proceso en que ellos cruzan la frontera y viven en Estados Unidos, han perdido doblemente el terruño como espacio rural. En primer lugar, al salir de Jalostotitlán para ir a ese país del norte como trabajadores migrantes, perdieron el terruño que aún era una sociedad dominantemente rural en aquella época en que la mayoría de los migrantes, que ahora están jubilados, nacieron y crecieron ahí. En segundo lugar, en el proceso de urbanización de Jalostotitlán al cual contribuyeron el proceso migratorio y los flujos transnacionales de gente, dinero, objetos y estilos de vida, ellos perdieron el paisaje rural del pueblo y los ranchos donde nacieron y crecieron. En este proceso de reducción y desaparición del espacio rural de Jalostotitlán y en el auge de la migración hacia Estados Unidos, el campo era considerado como un espacio de atraso, en cambio, 
la ciudad y el "Norte" eran vistos como espacios de progreso según la idea modernista de desarrollo.

Sin embargo, al desplazarse a Estados Unidos, los migrantes se situaron en otro contexto sociocultural en que la alienación que experimentaban en el trabajo y en la vida cotidiana en las zonas urbanas en ese país les hizo cuestionar el sueño americano. En esta situación, hubo un desplazamiento o subversión de significados de espacios, es decir, un cambio en la percepción del campo, la ciudad, el terruño y el Norte. Las ciudades donde ellos se asentaron en Estados Unidos ahora se narran como espacios de la vida solitaria y rutinaria sin un "verdadero" sentido de vida. En contraste con el Norte descrito de este modo, el terruño y los ranchos se imaginan como espacios donde ellos pudieran liberarse de las experiencias de alienación y tener una vida libre e independiente. En pocas palabras, aquí la migración no se entiende como un simple desplazamiento físico de las personas que buscan mejores oportunidades económicas a través del trabajo en otro lugar y país, sino como un desplazamiento espacial que también implica un "desplazamiento" de significados y sentimientos. ${ }^{138}$

Sin embargo, la estructura de sentimientos de los migrantes hacia Jalostotitlán construida de este modo se entrecruza con la lógica del tiempo de ocio en el contexto en que han surgido las vacaciones de los migrantes en el proceso de transición del campo a la ciudad tanto en el trabajo como en el lugar de residencia en Estados Unidos y se ha generalizado el retorno temporal masivo en sus vacaciones desde la segunda mitad de los años ochenta. En esta articulación de la construcción del terruño imaginario para los migrantes con la nueva práctica espacial y temporal de los migrantes, Jalostotitlán se imagina como un espacio rural lúdico para pasar el tiempo de ocio. Al mismo tiempo, la nostalgia entrecruzada con las expectativas de las vacaciones ha formado una parte importante de los motivos del viaje de retorno de los migrantes radicados en Estados Unidos en temporada de fiestas locales de Jalostotitlán.

${ }^{138}$ Véase Clifford (1999). En este texto, Clifford no usa el término "desplazamiento" sólo para referirse al movimiento de un lugar a otro, sino también como una práctica que constituye diversos significados culturales. 
Cabe recordar que Raymond Williams (1973) sostiene que la nostalgia hacia el campo que se basa en la idealización del campo y la desvaloración de la ciudad, es una manera de percibir y reaccionar a los cambios en su entorno social. En el caso de la formación de la nostalgia de los migrantes jalostotitlenses, el entorno social donde ha habido cambios no sólo es su terruño, sino también la sociedad receptora. En pocas palabras, la nostalgia jalostotitlense hacia el campo es un sentimiento que se ha formado como una manera de percibir y reaccionar a los cambios en su espacio de vida transnacional, el espacio de vida donde se articulan los procesos locales del terruño con los procesos que se han dado en Estados Unidos.

Sin embargo, la nostalgia hacia el terruño como espacio rural construida en el contexto transnacional opera sobre la realidad del terruño. El retorno temporal masivo de los migrantes en temporada de fiestas locales ha creado el contexto en que no sólo se hace contacto entre los migrantes y los habitantes de Jalostotitlán, sino también entre el terruño imaginario de los migrantes y el terruño como espacio físico. En esta "zona de contacto", varios actores locales se apropian de las imágenes rústicas de Jalostotitlán y utilizan la nostalgia hacia el pueblo rural lúdico como recurso económico y como capital cultural. Este nuevo proceso de transformación de Jalostotitlán se puede entender como un proceso de reconstrucción de la realidad de Jalostotitlán a partir del "simulacro" del pueblo rural o como un proceso de creación de "hiperrealidad" que materializa el imaginario popular de los migrantes sobre el pueblo y los ranchos en el terruño como espacio físico. Para los migrantes, el terruño que se reconstruye a través del reestreno del "pueblo rural" es un lugar donde puedan satisfacer su nostalgia en sus vacaciones y anular sus experiencias de alienación en Estados Unidos de manera "hiperreal".

Entonces, ¿cómo se podría definir esta localidad que se reconstruye a través de la formación de la nostalgia de los migrantes en el contexto transnacional y de la operación de la nostalgia sobre la realidad del terruño? ¿Qué tipo de ciudad sería Jalostotitlán que representa el ambiente del "pueblo rural" encima del contexto urbano? 
En su libro titulado Magical Urbanism: Latinos Reinvent the US City, Mike Davis (2000) explora cómo el aumento demográfico de los latinos ha transformado el paisaje urbano de grandes ciudades de Estados Unidos donde el creciente número de latinos se han asentado. Señala que a medida que las localidades de origen de los migrantes provenientes de América Latina y el Caribe se han integrado a la economía de las metrópolis de Estados Unidos a través de las migraciones transnacionales y la intensificación de flujos transnacionales de personas, dinero y símbolos, se han construido y fortalecido los vínculos sociales, económicos, políticos y culturales entre los países de origen y Estados Unidos. Davis llama "suburbios transnacionales" a los espacios suburbanos de las grandes ciudades, tales como, Nueva York, Los Ángeles, Chicago y Miami, donde se ha asentado un creciente número de migrantes latinos que mantienen vínculos con sus localidades de origen (Davis, 2000: 80).

A mi juicio, este tipo de espacio urbano que construye y fortalece el fuerte vínculo transnacional a través de la circulación de gente, dinero, objetos, símbolos, información y estilos de vida, no se observa solamente en Estados Unidos, sino también en la sociedad emisora de los migrantes mexicanos. Como expliqué en el primer apartado, Jalostotitlán pasó de ser una sociedad rural a otra urbana a través de la articulación del proceso de urbanización con los procesos transnacionales. La migración hacia Estados Unidos y la afluencia de personas, objetos, dinero, información y modos de vida derivados de ese país a la vida local contribuyeron de manera importante a la transformación de Jalostotitlán en una ciudad. Asimismo, las conexiones transnacionales también han jugado un papel importante en el proceso reciente de reconstrucción de esta localidad. Como expliqué en el cuarto apartado, el retorno temporal masivo de los migrantes radicados en Estados Unidos durante su tiempo de ocio y las imágenes rústicas de Jalostotitlán construidas en Estados Unidos han contribuido de manera fundamental al nuevo proceso de transformación de Jalostotitlán en que se representa el ambiente del "pueblo rural" encima del contexto urbano. En este sentido, Jalostotitlán es una ciudad transnacional que surgió en la sociedad emisora de los migrantes. 
Sin embargo, la rusticidad que se representa en el nuevo proceso de transformación de Jalostotitlán, no es la imagen de espacio rural ni la de ciudad concebida en el pensamiento modernista en el que se basa la idea convencional de desarrollo. Blanca Ramírez y Patricia Arias (2002) señalan que el pensamiento moderno que privilegió una concepción fraccionada, dicotómica y restringida del tiempo y el espacio se observa en la forma convencional de definir las relaciones campo-ciudad. En esta definición, el campo ha sido concebido como espacio inmóvil, estético, pasivo y de atraso, en cambio la ciudad ha sido definida a partir del oponerlo al espacio dinámico y de innovación, progreso y desarrollo que se ubica en las zonas urbanas. En este modo dicotómico de ver las relaciones entre el campo y la ciudad, el desarrollo significa la eliminación del espacio rural a través de la urbanización y la industrialización de la sociedad. Pero lo que proponen Ramírez y Arias, escapando de esta visión dicotómica de definir las relaciones entre el campo y la ciudad, es buscar una nueva rusticidad que permita "abrir las nociones de campo y ciudad a las relaciones y a la diferencia" para percibir "la diversidad interna de los espacios" y aceptar que "en cada uno de ellos se recrean relaciones socioespaciales que han sido vividas, elaboradas, procesadas, e imaginadas de diferentes maneras por las diversas sociedades rurales [...] y urbanas" (12).

Retomando este argumento, se puede decir que el caso de la reconstrucción del espacio urbano de la localidad de Jalostotitlán a través del reestreno de la imagen del "pueblo rural", es un ejemplo de la creación de una nueva rusticidad. En el proceso de transición del espacio rural al urbano, la idea modernista de desarrollo, en la cual el campo era considerado como espacio de atraso, en cambio, la ciudad y el Norte eran vistos como espacios de progreso, fue el motor principal que desplazó a aquellos jalostotitlenses que buscaban el progreso y el mejoramiento de vida al centro de la localidad y a Estados Unidos. En el proceso en que Jalostotitlán se transformó en ciudad a través de la articulación entre la urbanización local con el proceso migratorio y los flujos transnacionales, la concepción dicotómica del tiempo y espacio prevaleció en el modo de definir la relación entre el campo y la ciudad, entre lo tradicional y lo moderno y entre el 
pasado y el futuro. En la concepción dicotómica modernista del tiempo y el espacio, se consideraban que estos elementos eran incompatibles y que para buscar el progreso y el desarrollo, se debían sacrificar los primeros términos.

Sin embargo, en la estructura de sentimientos nostálgicos, los significados del tiempo y el espacio subvierten. Ahora, el campo, la tradición y el pasado, que fueron marginados en la idea modernista de desarrollo, se imaginan por los migrantes como elementos revalorados. En el nuevo proceso de transformación de Jalostotitlán, donde se materializa el imaginario popular de los migrantes sobre el paisaje rural, el estilo de vida tradicional y el pasado idealizado, la relación entre el campo y la ciudad, entre lo tradicional y lo moderno, entre el pasado y el futuro y entre la ficción y la realidad se vuelve compatible. El estilo de vida rural tradicional se reconstruye, se mercantiliza, se representa y se presenta en forma idealizada en el tiempo y espacio ritual y de ocio. La realidad del terruño se modifica para materializar la ficción del pueblo rural en el contexto urbano. La imagen idealizada del pasado se presenta como un proyecto actual de reconstrucción de Jalostotitlán para tener una mejor imagen local en el futuro.

En suma, Jalostotitlán es una ciudad posmoderna que hace un rompimiento con el modo moderno de percibir el campo y la ciudad, yuxtapone lo rural y lo urbano y crea el ambiente del espacio rural de modo ecléctico por encima del contexto urbano. ${ }^{139} \mathrm{El}$ "pueblo rural" que se representa en esta ciudad no es un pueblo definido por sus características demográficas y geográficas. Tampoco es un espacio rural visto como espacio de atraso. El estilo de vida "ranchera" que se representa en esta ciudad no es un modo de vida en los ranchos como unidades sociales que existieron antes como principales unidades sociales de Jalostotitlán. Más bien, lo que se representa en los escenarios festivos de esta ciudad es un "simulacro" del espacio rural construido en forma idealizada a partir de la "ruptura de la cadena de significación" histórica del pueblo y de los ranchos (Jameson, 1984:71). Es una imagen del espacio rural que tiene una connotación placentera y lúdica para aquellos que pasan vacaciones en esta ciudad transnacional.

${ }^{139}$ Véanse las características constitutivas de lo posmoderno que explica Jameson (1984). 


\title{
Capítulo 4
}

\section{Viajes sagrados: Migración y Prácticas religiosas transnacionales}

\begin{abstract}
La Virgen de la Asunción señorea la vida del pueblo desde la época Colonial [...] Es como la patria espiritual de aquel pueblo; como su misma alma; como su propia conciencia; como su íntimo valer. Nunca se podrá arrancar ese culto a la imagen que se ha adentrado en la vida del pueblo, como historia, como religión, como consuelo y como amor. (“Fiestas de Agosto", Pedro Rodríguez Lomelí, 1976, En un pueblo alteño, pp.76-77.)
\end{abstract}

\section{INTRODUCCIÓN}

En la década de los años treinta del siglo XVI, las tropas de los españoles bajo el mando de Nuño de Guzmán estaban ampliando la conquista en la parte occidente de México, desde Jalisco hasta Sinaloa y una parte de Zacatecas, la cual fue denominada Nueva Galicia. ${ }^{140}$

Paralelamente a esta expedición conquistadora en el occidente de México, los misioneros franciscanos estaban recorriendo los Altos de Jalisco con el fin de predicar el cristianismo a los indios de esta región. Una de las figuras importantes entre estos misioneros para la historia de Jalostotitlán era Fray Antonio de Segovia, quien fue el primer misionero que visitó la región en la que actualmente se encuentra Jalostotitlán y llevó el cristianismo a esta tierra. Después de la pacificación de la insurrección de Mixtón que se dio en 1541, este misionero nombró a Fray Miguel de Bolonia para reconstruir y reorganizar esta zona. Construyó una iglesia provisional y un pequeño hospital para atender a los nativos recién cristianizados. Dejó una imagen de la Virgen de la Expectación en la capilla del hospital. De este modo, fundó un pueblo llamado El Divino Salvador de Xalostotitlán a mediados del siglo XVI. ${ }^{141}$

No se sabe con certeza cómo y cuándo llegó a este pueblo la imagen de la Virgen de la Asunción que es la actual patrona de la parroquia de Jalostotitlán. Pero, según la tradición oral heredada por generaciones entre los habitantes de

\footnotetext{
${ }^{140}$ Gutiérrez Gutiérrez (1985: 67-79); Padilla (1988: 43-48).

141 Gutiérrez Gutiérrez (1985:104-111); Padilla (1988: 62-66).
} 
Jalos, se cree que esta imagen fue donada por el mismo padre Bolonia a mediados del siglo XVI, y ha sido considerada como Patrona de la parroquia de Jalostotitlán desde el siglo XVII. ${ }^{142}$

Desde entonces hasta la actualidad, la devoción por esta imagen religiosa ha sido uno de los ejes de la sociedad jalostotitlense y la identidad local. ${ }^{143} \mathrm{Sin}$ embargo, la creencia y las prácticas religiosas locales, que se desarrollaron en torno a esta imagen en Jalostotitlán a lo largo de los siglos, se han extendido al exterior de Jalostotitlán acompañando el éxodo masivo de las personas hacia el Norte en los procesos migratorios laborales que comenzaron a principios del siglo XX. En otras palabras, como diría el autor de la prosa que cité en la página anterior, la separación física con el terruño no ha podido arrancar el apego a esta imagen sagrada del terruño que se ha adentrado en la vida de los migrantes jalostotitlenses.

En este capítulo, pretendo analizar las conexiones transnacionales entre Jalostotitlán y California que se han construido a raíz de la migración hacia Estados Unidos, a partir de enfocarme en el nexo entre la migración y las prácticas religiosas de los migrantes. Exploraré cómo el desplazamiento de las personas y de los símbolos se relaciona con las prácticas religiosas y cómo éstos han contribuido a la construcción, el mantenimiento y el fortalecimiento de vínculos sociales, emocionales y simbólicos extendidos más allá de la frontera nacional. Para ello, en los siguientes cuatro apartados, primero presentaré descripciones de algunos casos etnográficos sobre las prácticas religiosas que se han desarrollado tanto en el país receptor de los migrantes jalostotitlenses como en su terruño a través de la inserción de las imágenes sagradas de su lugar de origen en el contexto transnacional.

${ }^{142}$ Padilla (1988: 74, 75, 194).

${ }^{143}$ Gutiérrez Gutiérrez sostiene que la religión ha sido uno de los ejes de la sociedad jalostotitlense y que la iglesia católica está ligada históricamente a la formación de la ciudad de Jalostotitlán y del municipio (1985: 276-283). Pedro Rodríguez Lomelí, escritor originario de Jalostotitlán, también afirma que en su pueblo natal "el centro de la vida está en la iglesia" y la Virgen de la Asunción es la patrona de esta localidad que gobierna la vida espiritual de sus habitantes (1976: 5, 16). Según José Luis López Ulloa (2002), investigador originario de Jalostotitlán, la religión, la tierra y la familia son tres ejes de la formación histórica de la identidad social en los Altos de Jalisco. 
Los primeros dos apartados tratan acerca de las descripciones de las prácticas religiosas de los migrantes jalostotitlenses radicados en California, las cuales se originaron con la iniciativa del club y la organización religiosa de los migrantes y se han desarrollado a través de la inserción de las réplicas de la imagen de la Virgen de la Asunción de Jalostotitlán y las prácticas religiosas locales en sus lugares de destino en California.

Sin embargo, como ilustra el caso de la fiesta de la Virgen de la Asunción en Turlock que se presenta en el segundo apartado, las prácticas religiosas populares de los migrantes se incorporan al nivel institucional de la iglesia local del lugar de destino. Este aspecto del acercamiento de las instituciones religiosas a los migrantes a través del uso del discurso sobre el terruño como fuente de la fe católica y del símbolo local, también se observa en el tercero y cuarto caso etnográfico sobre las prácticas religiosas de los migrantes que se insertan en el contexto transnacional.

En el tercer apartado, presentaré el caso de las prácticas religiosas del lugar de origen que se modificaron y se desarrollaron al reincorporar a la población migrante radicada en Estados Unidos a la parroquia de Jalostotitlán. En contraste con los primeros dos casos que revelan el vínculo entre la migración hacia Estados Unidos y la dimensión religiosa de la vida de los migrantes en ese país, este caso trata de las prácticas religiosas que se han desarrollado en torno al retorno temporal de los migrantes. Para poder estar presentes en el ritual más importante de su terruño, los migrantes jalostotitlenses no sólo han organizado las fiestas patronales de Jalostotitlán en el país receptor, sino también regresan físicamente a su terruño. Sin embargo, el contacto entre los migrantes y el lugar sagrado del terruño no ha sido posible solamente por el viaje de los migrantes al terruño, sino también por el acercamiento de la iglesia de Jalostotitlán a los migrantes. En este caso, el principal actor que hace resignificación de las prácticas religiosas locales en el contexto transnacional es la iglesia del lugar de origen.

En el cuarto apartado, se presenta el caso de la peregrinación en Santa Ana de Guadalupe, una comunidad perteneciente al municipio de Jalostotitlán, la cual es el lugar de nacimiento de Santo Toribio Romo que fue el mártir de la guerra 
cristera. Este caso ilustra que la iglesia del país de origen de los migrantes juega un papel crucial en la difusión de la devoción por esta figura regional más allá de la frontera nacional.

Después de la descripción de estos cuatro casos etnográficos, finalmente explicaré algunas implicaciones acerca de la construcción de las conexiones transnacionales entre Jalostotitlán y Estados Unidos a través del análisis de estos cuatro casos etnográficos. En ese último apartado del capítulo, mi argumento sobre las conexiones transnacionales en la dimensión religiosa de la vida de los migrantes jalostotitlenses se centra principalmente en el análisis de la construcción y el fortalecimiento de vínculos sociales, emocionales y simbólicos transnacionales a través de estas prácticas religiosas.

\section{LA RÉPLICA DE LA IMAGEN DE LA VIRGEN DE LA ASUNCIÓN EN EL SUR DE CALIFORNIA}

El 3 de noviembre de 1946, el padre Salvador Quezada Limón llegó a Jalos como nuevo párroco. Observando la inmensa devoción que tenían los habitantes por la imagen de la Virgen de la Asunción, se le ocurrió la idea de promover su coronación canónica. Le comentó esta idea al padre José María Cornejo, sacerdote originario de Jalos que en ese tiempo estaba en el cargo de canónigo en la catedral de Guadalajara. Estos dos sacerdotes le propusieron este proyecto al arzobispo José Garibi Rivera de la Arquidiócesis de Guadalajara. Finalmente su petición fue aprobada por el arzobispo, y posteriormente el decreto de coronación fue promulgado por el Vaticano. ${ }^{144}$ El 15 de agosto de 1948 se celebró la coronación de la Virgen de la Asunción de Jalostotitlán.

Unos años después de esta celebración, se hizo una nueva imagen de la Virgen de la Asunción, copia fiel de la original, la cual fue bendecida por el arzobispo Garibi en 1950. Esta réplica de la imagen de la Virgen, que ahora se conoce como "La Peregrina", se hizo con el fin de visitar los hogares tanto en el pueblo de Jalostotitlán como en los ranchos de la jurisdicción de la parroquia. Posteriormente, se amplió el espacio de su visita. Del día primero de febrero al 31

${ }^{144}$ Padilla (1988: 188, 194, 196, 204). 
de julio, esta imagen de la Virgen se encontraba en Guadalajara visitando los hogares de los jalostotitlenses radicados en esta ciudad. Según lo que describe el cronista José Trinidad Padilla Lozano en su libro publicado en 1988, la imagen permanecía 24 horas en cada uno de los 182 hogares o templos en donde las familias originarias de Jalos la veneraban. Después de seis meses de estancia en Guadalajara, la imagen peregrina se trasladaba a Jalostotitlán para incorporarse a la celebración de sus fiestas patronales y acompañar a los fieles en distintas ceremonias religiosas. ${ }^{145}$ Esta tradición continúa hasta la fecha, con la visita de la virgen a los hogares de sus fieles en Jalostotitlán y en Guadalajara.

Pero hay otras réplicas de la imagen de la Virgen de la Asunción que viajaron al exterior de Jalostotitlán para acompañar las prácticas religiosas colectivas de los hijos ausentes: una réplica se encuentra en el sur de California y otras dos en el norte del mismo estado. ${ }^{146}$

No se sabe con certeza en qué año llegó la imagen de la Virgen de la Asunción a Los Ángeles, California. Pero, entre finales de los años sesenta y principios de los setenta, se le ocurrió al entonces párroco de Jalostotitlán la idea de llevar una réplica de la imagen de la Virgen a California con el fin de hacer una rifa entre los ausentes para recolectar la donación. Primero, la mandó con una persona de Jalos en un camión de carga para pasar la frontera por Tijuana sin papeles aduanales. Algunos migrantes llaman a esta imagen, con cariño, la "Virgen indocumentada" porque cruzó la frontera sin papeles igual que muchos migrantes jalostotitlenses que llegaron a California en esa época. Pero, cuando el párroco llegó al sur de California, uno de los directivos del Club Social Jalostotitlán de Los Ángeles le propuso al párroco otra idea: en vez de hacer la rifa, el Club Social Jalostotitlán donaría a la parroquia la misma cantidad del dinero que pretendía recolectar el párroco con la rifa, para que esta réplica perteneciera a todas las personas originarias de Jalos que radicaban en el sur de California. Al

145 Padilla (1988: 255).

${ }^{146}$ En realidad, hay dos réplicas de la imagen de la Virgen de la Asunción en el sur de California. Una es la que pertenecía al Club Social Jalostotitlán de Los Ángeles, y la otra es de una familia originaria de Jalostotitlán. Esta segunda no se usa de manera colectiva para las prácticas religiosas entre otros migrantes jalostotitlenses, más bien es para las prácticas religiosas familiares. 
párroco también le pareció mejor esta idea que su plan inicial. Desde entonces, esta imagen de la Virgen ha peregrinado entre los hogares de los jalostotitlenses y ha acompañado la celebración de su fiesta patronal de agosto en el sur de California.

El Club Social Jalostotitlán de Los Ángeles fue fundado en 1967 por un grupo de personas originarias de Jalostotitlán. Se hicieron el escudo del club y el lema. Era una organización, sin fines de lucro, fundada con el objetivo de ayudar a los demás y de convivir con los paisanos de Jalostotitlán. La mesa directiva se componía de diferentes cargos: presidente, vicepresidente, secretario, subsecretario, tesorero, subtesorero, encargado de relaciones sociales y su asistente, el encargado de festejo y su asistente. Una de las actividades importantes de este club de los migrantes era la celebración del Baile de Coronación de la Reina, seleccionada cada año por concurso entre las candidatas originarias de Jalostotitlán. A través de la celebración de este evento, el club les ofrecía a los migrantes jalostotitlenses y a sus familias la oportunidad para convivir con sus paisanos, y al mismo tiempo, recolectaban la donación para dar apoyos económicos y materiales a su lugar de origen, en donde todavía había mucha pobreza. Por ejemplo, en 1974, el Baile de Coronación de la Reina se celebró el 27 de julio, sábado, de las 9:00 P.M a las 2:00 A.M en el salón del Blarney Castle ubicado en el número 607 de la avenida South Western en Los Ángeles. El donativo para este evento era de cinco dólares. Este evento tuvo la asistencia de cerca de 800 personas. Aparte del Baile de Coronación de la Reina, en otros años se organizaban el baile el 31 de diciembre y el baile de carnaval en marzo.

Otras actividades recreativas del club eran un pic nic y reuniones para el cómputo de los votos del certamen de la reina realizados en distintos lugares de Los Ángeles. En estas ocasiones, se recolectaba la cooperación entre los participantes para dar apoyos económicos y materiales a su lugar de origen.

Desde finales de los años sesenta hasta la segunda mitad de los años setenta, esta organización había dado distintos apoyos a las instituciones y a las personas menos beneficiadas de Jalostotitlán, a base de los recursos económicos recaudados por los migrantes en las actividades recreativas. Por ejemplo, les 
había otorgado becas a los estudiantes de la escuela secundaria, regalos para niños de las familias de escasos recursos en la navidad, despensas a las familias más necesitadas, donación al asilo de ancianos y al hospital y cobijas a los indigentes. Entre los apoyos que había dado el club a su lugar de origen, la donación de la ambulancia fue uno de los apoyos materiales que los ex directivos del club y otros migrantes recordaban y narraban con orgullo y satisfacción, dado que la ambulancia que el Club Social Jalostotitlán de Los Ángeles mandó a su terruño contribuyó a la fundación de la Cruz Roja de Jalostotitlán en 1973.

Aparte del Baile de Coronación de la Reina, otro evento grande que organizaba el club social cada año era la celebración de la fiesta de la Virgen de la Asunción en agosto. Coordinaba con alguna iglesia católica de Los Ángeles la celebración de la fiesta religiosa. Aunque el 15 de agosto es el día más importante de las fiestas patronales de la Virgen de la Asunción, ese día no caía en un día de fin de semana todos los años. Por eso, en algunos años, se organizaba la festividad un sábado antes del día 15 de agosto, dado que la mayoría de los ausentes tenían que trabajar en ese día si el 15 caía entre semana. La fiesta se celebraba en alguna iglesia católica de Los Ángeles, donde muchos de los migrantes vivían concentrados. Por ejemplo, en 1971 se organizó la fiesta patronal el 15 de agosto en el Templo de Saint Peter Catholic Church, ubicado en la avenida Broadway, Los Ángeles. Hubo una misa a las 12:00 del día. Cabe señalar que después de la llegada de la réplica de la imagen de la Virgen de la Asunción de Jalostotitlán, la fiesta patronal se celebraba con la presencia de esta imagen que peregrinaba entre los hogares de las familias originarias de Jalos radicados en el sur de California, igual que la réplica de la imagen que peregrinaba entre Guadalajara y Jalostotitlán.

Era evidente que se habían reforzado los lazos sociales entre los jalostotitlenses del sur de California a través de los eventos y actividades del Club Social Jalostotitlán. A los eventos no sólo llegaban aquellas familias originarias de Jalos que vivían en Los Ángeles, sino que venían de distintos condados del sur de California. 
Por el otro lado, los eventos sociales y religiosos organizados por este club eran también ocasiones de reencuentro entre las familias, parientes, amigos y novios que habían estado separados a pesar de haber llegado a California, y a la vez, eran buenas ocasiones para que los migrantes solteros conocieran a las mujeres de su terruño y comenzaran el noviazgo. De hecho, las personas que estaban en la mesa directiva recordaban que había varias parejas que se conocieron y reencontraron en el baile y posteriormente se casaron.

Asimismo, eran momentos oportunos para crear el vínculo social con la comunidad mexicana de Los Ángeles y con otras asociaciones y clubes de migrantes mexicanos de otras localidades de Jalisco y de otros estados. Por ejemplo, en el Baile de Coronación de la Reina celebrado en 1974 fueron invitados varios clubes de los migrantes de los estados del occidente y norte de México, organizaciones de mexicanos y la prensa para la población mexicana. ${ }^{147}$

Lo interesante del baile de ese año fue que entre los invitados externos estaba el nombre del entonces presidente del municipio de Jalostotitlán. El presidente municipal de Jalos fue invitado para coronar a la reina electa. En el apartado anterior, comenté que el Club Social Jalostotitlán de Los Ángeles mantenía un vínculo social con su lugar de origen por medio de sus actividades filantrópicas. Pero este vínculo social no necesariamente se había creado y mantenido de manera unilateral por los migrantes porque este presidente municipal no fue a Los Ángeles solamente como invitado del evento, sino para dar un reconocimiento al club social de sus paisanos por los apoyos que habían brindado a Jalostotitlán.

A pesar de que había jugado un papel importante para fortalecer las redes sociales entre los migrantes radicados en el sur de California y había tenido una fuerte presencia en la vida de muchas familias originarias de Jalos que se

${ }^{147}$ En el programa del Baile de Coronación de la reina de 1974, aparecen los nombres de los siguientes clubes de migrantes, organizaciones y prensas de la comunidad mexicana en Los Ángeles: Club Social Ávalos, Chihuahua, Club Social Guadalupe Victoria, Zacatecas, Club Social Fresnillo, Zacatecas, Cámara de comercio de damas mexicanas, Club Social Nayarit, Club Social Huejucar, Jalisco, Club Social Zacatecano, Asociación de Charros la Alteña, Club Villa López, Chihuahua, conductor del programa de radio local, Presidente de la Beneficencia Mexicana, Presidente del Comité Cívico Mexicano, periódico La Opinión, periódico El Heraldo de México. 
encontraban en el sur de California desde finales de los sesenta hasta la segunda mitad de los setenta, el Club Social Jalostotitlán de Los Ángeles terminó sus actividades. Los ex integrantes de la mesa directiva no recuerdan muy bien en qué año exactamente terminó el club. Pero desde finales de los años setenta, habían desaparecido paulatinamente las actividades del club, y a principios de los ochenta prácticamente desapareció esta organización. ${ }^{148}$

El Club Social Jalostotitlán de Los Ángeles no fue la única organización de migrantes jalostotitlenses que existía en California. De hecho, había otras organizaciones que tenían el nombre de Club Social Jalostotitlán. Según un migrante jubilado de Sacramento, con el círculo de los paisanos y sus actividades, él y sus amigos fundaron en los años sesenta el Club Social Jalostotitlán en Sacramento, la capital del Estado de California que ha sido uno de los destinos clásicos de migrantes jalostotitlenses desde principios del siglo XX. Esta organización también tenía distintos cargos en la mesa directiva y elección del presidente. Él fue el primer presidente y estuvo en este cargo durante 13 años. Uno de los eventos principales que organizaba este club de Sacramento era la celebración del día 15 de agosto para venerar a la Virgen de la Asunción y el "paseo del pueblo" para las familias originarias de Jalos que no podían regresar a su terruño en agosto. ${ }^{149}$ Igual que el club de Los Ángeles, este club contaba con una réplica de la imagen de la Virgen de la Asunción de Jalostotitlán que fue llevada a Sacramento en los años sesenta. Actualmente esta imagen está guardada en la iglesia de Guadalupe de la ciudad, donde se organizaba la misa para el 15 de agosto en aquella época. ${ }^{150}$

${ }^{148}$ Los jalostotitlenses que participaban en los eventos expresaban su añoranza por aquellos días en que el Club Social Jalostotitlán organizaba el baile y reuniones en los años setenta. Había personas que se lamentaban por la desaparición de las actividades del club y esperaban su reorganización (Jáuregui Pérez, 1981: 21, 36).

${ }^{149}$ El "paseo del pueblo" era originalmente un evento que organizaba la parroquia de Jalostotitlán el día 17 de agosto para hacer una convivencia en el campo con todos los habitantes de la localidad. Véase el apartado titulado "Reestreno del pueblo rural" en el capítulo 3 de esta tesis.

${ }^{150}$ En 1973, existían tres organizaciones en California (el club de Sacramento, el de Los Ángeles y otro que comenzó a formarse en el mismo año en Anaheim) y otra en Guadalajara con el mismo nombre de "Club Social Jalostotitlán". Ante esta situación, el entonces presidente del Club Social Jalostotitlán de Los Ángeles, decidió registrar esta organización ante el gobierno del estado de California para que fuera el número uno del Club Social 
Después de que el Club Social Jalostotitlán de Los Ángeles había desaparecido, por un tiempo la imagen de la Virgen se quedó sin moverse. Se quedó en la casa de uno de los ex presidentes del club en Downey, condado de Los Ángeles. Cuando él se fue a vivir de manera definitiva a Jalostotitlán, la dejó con su hermana. Después, el Sr. Jesús Jáuregui, quien es uno de los coordinadores actuales de la "visita de la Virgen", se hizo responsable de cuidar la imagen. Desde entonces, la imagen ha andado, de nuevo, peregrinando entre las casas de los jalostotitlenses de diferentes ciudades y de distintos condados en el sur de California y las prácticas religiosas en torno a esta imagen siguieron creciendo. Al principio, esta réplica de la imagen de la Virgen peregrinaba entre las casas de los migrantes jalostotitlenses permaneciendo durante una semana en casa. Pero, ahora la estancia de la imagen en cada hogar se redujo a tres días porque ha habido más familias que le solicitan a él y a otro coordinador la visita de la imagen de la Virgen. Actualmente hay aproximadamente 300 direcciones de casas de jalostotitlenses que solicitan la visita. Hay alrededor de 40 direcciones registradas en Anaheim.

Las fiestas patronales de agosto también se han celebrado con la presencia de la imagen de la Virgen, pero de una manera más organizada y a mayor escala. En comparación con la fiesta religiosa que se celebraba solamente en un día en una iglesia católica de Los Ángeles, ahora se da la misa para venerar a la Virgen de la Asunción duante varios días del mes de agosto y en ocasiones, en las iglesias de diferentes ciudades y condados. Por ejemplo, en 2001, la misa se llevó a cabo el 12 de agosto, domingo, a las 12:30 en la Iglesia de San Juan Evangelista en Los Ángeles, y el 15 de agosto, miércoles, a las 7:00 P.M. en la Iglesia de San Bonifacio en Anaheim; en el año 2002, del 6 al 10 de agosto, se rezaba el rosario a las 7:00 P.M y la misa el 11 a las 3:30.P.M. en la Iglesia de San Lorenzo de Brindisi en Los Ángeles, y otra misa el 15 de agosto a las 7:00 P.M. en la iglesia de San Bonifacio en Anaheim; en el año 2003, se rezaba el rosario del 6

Jalostotitlán, oficialmente registrado entre los cuatro clubes que existían en el mismo momento. 
al 9 de agosto a las 7:00 P.M., la misa y el rosario del 10 al 15 del mismo mes a las 6:30 o a las 7:30 P.M.

En los años recientes, los coordinadores de la organización de las fiestas patronales han tomado varias medidas para dar información de la celebración. Se reparten cerca de 1000 invitaciones y se creó la página de Internet. Asimismo, los gastos de la organización del evento se cubren a través del fondo de la imagen de la Virgen de la Asunción y del patrocinio de docenas de personas originarias de Jalostotitlán. Por ejemplo, en la celebración de la fiesta patronal el 15 de agosto de 2003 en la iglesia San Lorenzo de Brindisi en Los Ángeles, hubo 50 personas que patrocinaron 60 dólares por persona. Con este dinero que en total sumó 3000 dólares, se cubrió gran parte de los gastos y además, se hizo una rifa de un boleto para viajar a Jalos para dos personas. La compañía Northgate González Market pagó los gastos de la comida para toda la gente, y el pago de la música de banda se cubrió con el fondo de la imagen. En el mismo año también se organizó el "paseo del pueblo" el 17 de agosto en el parque de South Gate, condado de Los Ángeles, como si fuera una versión de "revival" del "paseo del pueblo" organizado por la parroquia de Jalostotitlán el mismo día del mismo mes algunas décadas atrás, una tradición local que existía antes en Jalostotitlán en el proceso de transición del espacio rural al urbano. ${ }^{151}$

Hay algunos factores que permiten explicar el aumento tanto de la visita de la imagen de la Virgen de la Asunción, como de la celebración de las fiestas patronales. En primer lugar, el aumento de los participantes en estas prácticas religiosas tiene que ver con el hecho de que la salida de la población de Jalostotitlán hacia Estados Unidos ha aumentado drásticamente a partir de 1986, el año en que se aprobó la Immigration Reform and Control Act (IRCA), conocida como "Ley Simpson-Rodino", que permitió la legalización de la residencia en Estados Unidos de 2300000 migrantes mexicanos. A partir de entonces, la migración jalostotitlense hacia Estados Unidos aumentó drásticamente por intentar entrar a la categoría de "migrante con papeles" y buscar una mejor oportunidad económica cuando México estaba en una crisis (González de la Rocha y Escobar

${ }^{151}$ Véase el apartado titulado "Reestreno del pueblo rural" del capítulo 3 de esta tesis. 
Latapí, 1990). Otro factor importante que influyó en el aumento del número de los jalostotitlenses en California es que el flujo migratorio a partir de la segunda mitad de los años ochenta ha tendido a ser una migración familiar más que individual (González de la Rocha y Escobar Latapí, 1990). Al establecerse en ese país con sus familias, los migrantes han podido aumentar el número de miembros de sus familias. Sus hijos crecen y se casan y luego, participan con sus parejas e hijos en las prácticas religiosas de los migrantes de primera generación. Hoy en día, el desarrollo de las familias de migrantes jalostotitlenses es, de cierta manera, un "problema" para organizar fiestas familiares en California. Por ejemplo, en el caso de un migrante radicado en South Gate, Los Ángeles, que tiene varios hermanos y familiares de su esposa en California, para celebrar la navidad en la casa de algún familiar, llegan varios migrantes casados de la primera generación, sus hijos, nietos, e incluso bisnietos. En total, llegan alrededor de 200 o 250 personas a la fiesta. El problema es que si el anfitrión vive en la zona urbana no tiene dónde estacionar los coches de los invitados.

Otro factor importante que influyó en el aumento de los participantes en las prácticas religiosas y sobre todo en la celebración de las fiestas patronales en el sur de California, es que todavía hay muchas personas que no pueden regresar a Jalostotitlán en agosto por su situación migratoria, por cuestión económica, o por otros compromisos con sus familias y de negocio; aunque han aumentado también el número de los ausentes que regresan temporalmente a su tierra natal en temporada de fiestas locales desde la segunda mitad de los años ochenta.

\section{LA RÉPLICA DE LA IMAGEN DE LA VIRGEN DE LA ASUNCIÓN EN TURLOCK}

En el año 2003, la tercera réplica de la imagen de la Virgen de la Asunción llegó a la iglesia católica, Sacred Heart Catholic Church, en Turlock, en el condado de Stanislaus, ubicado en el norte de California. El motivo de su traslado de Jalostotitlán al norte de California era para incorporarse a la celebración de la fiesta de la Virgen de la Asunción el 15 de agosto que se ha organizado en los años recientes en esta iglesia con la coordinación de un grupo de personas originarias de Jalostotitlán radicadas en esta ciudad. 
Los jalostotitlenses comenzaron a llegar a Turlock desde principios de los años sesenta para trabajar en los campos agrícolas. Primero, llegaron solamente los hombres. Ahora hay muchas fábricas y otros sectores de trabajo en los cuales se insertan los migrantes de la primera generación y los jalostotitlenses profesionistas de segunda y tercera generación. Pero al principio, todos los migrantes jalostotitlenses pasaron por el trabajo en los campos de cultivo de durazno, uvas, almendra, nuez, chabacano, etc. Los Pérez, los Gutiérrez, los Franco y los González fueron las principales familias que llegaron a Turlock. Después de tener trabajos estables, los migrantes, hombres, llamaron a sus familias a esta ciudad. En algunos casos, emigró prácticamente toda la familia que vivía en Jalostotitlán.

Han pasado más de cuatro décadas desde que llegaron los primeros jalostotitlenses a Turlock. Durante este tiempo la población originaria de Jalostotitlán ha crecido en esta ciudad. Ahora, ahí viven cerca de 100 familias de migrantes nacidos en Jalos. Si se incluyen las familias de la segunda generación, el número de las familias originarias de Jalos alcanza aproximadamente 200. Incluso, hay familias que tienen miembros de cuarta generación.

Muchos de los jalostotitlenses de esta ciudad no han podido regresar a su tierra natal cada año en el mes de agosto para asistir a las fiestas patronales. Por ejemplo, un migrante que llegó a Estados Unidos por primera vez en 1967, pudo estar en Jalos en agosto sólo dos veces durante casi 40 años de su vida migratoria en ese país. Otro jalostotitlense, quien tiene un campo agrícola, no ha podido regresar a Jalos para las fiestas patronales durante más de 40 años.

Una razón importante por la cual muchos de los migrantes de esta ciudad han tenido dificultad en realizar el retorno temporal cada año en el mes de agosto es porque las fechas de las fiestas religiosas de Jalostotitlán caen en medio de la temporada de cosecha de los productos agrícolas en esta área. Por ejemplo, la temporada de cosecha de uva, almendra y durazno dura casi tres meses y medio. Comienza en julio y termina en la primera semana de octubre. Por eso, aquellos jalostotitlenses que trabajan en este sector regresan a su tierra natal fuera de esta temporada. 
Existen otros factores que les dificultan a muchos jalostotitlenses regresar cada año a su lugar de origen en esta temporada. Por ejemplo, en algunos casos, ya no hay tanta necesidad de hacer esfuerzos para regresar a Jalos para ver a sus familias y parientes porque la mayoría de ellos se encuentran en Estados Unidos; en otros, tienen que estar con sus hijos por sus escuelas y sus actividades; otros más cuando acababan de llegar a California, no podían salir del país porque no tenían los documentos necesarios para legalizar su estancia; y finalmente por la cuestión económica, algunos jalostotitlenses de segunda generación no pueden regresar cada año a su lugar de origen porque tienen que visitar, aparte de Jalos, diferentes lugares de México, donde viven los padres y familiares de sus esposas, lo cual implica gastos fuertes de viaje.

Por estas razones, para los jalostotitlenses de Turlock ha sido difícil estar en las fiestas religiosas de su tierra natal cada año. A pesar de sus experiencias de separación del tiempo y espacio ritual de su lugar de origen, ellos no han perdido la creencia y el apego por la Virgen de la Asunción y han tratado de conservar las prácticas religiosas locales de Jalostotitlán. Por ejemplo, cuando aún no había la celebración del 15 de agosto como se festeja hoy en día, se reunían los paisanos y participaban en la misa de la iglesia católica de Turlock el 15 de agosto para celebrar la fiesta de la Virgen de la Asunción aunque era una misa normal de la iglesia.

Con base en estas prácticas religiosas locales, se reunieron algunos migrantes originarios de Jalos y formaron la Asociación de Nuestra Señora de la Asunción, dentro de la iglesia católica de Turlock. Sus integrantes son 15 personas originarias de Jalostotitlán y sus esposas(os). En total son 30 personas. Los esfuerzos de esta asociación y su devoción por la Virgen de la Asunción dieron fruto por fin, y en el año 2001 la fiesta patronal de esta Virgen se celebró como una fiesta oficial de la parroquia de Sagrado Corazón en Turlock el 15 de agosto del mismo año.

Según la Sra. Esperanza, originaria de Jalostotitlán e integrante de la Asociación de Nuestra Señora de la Asunción, el motivo por el cual la asociación promovió en la iglesia la celebración de la fiesta del 15 de agosto fue que ella y 
sus compañeros sentían la necesidad de transmitir y promover a las siguientes generaciones las costumbres y tradiciones de su tierra natal porque en muchas ocasiones no han podido regresar a su lugar de origen con sus hijos.

La celebración de la Virgen de la Asunción el 15 de agosto, organizada por esta asociación, cuenta con la participación de la población hispana de Turlock. Como hacen en Jalos, se celebran las mañanitas a la Virgen, la peregrinación y la misa. La peregrinación recorre las calles de la ciudad acompañada por un grupo de danzantes aztecas y un grupo de charros que llevan una bandera de México y otra de Estados Unidos. Después de la misa, se hace la convivencia entre los fieles. Hay música de banda y puestos de comida mexicana, frutas y bebidas. La asociación es la que organiza la fiesta, pero se prepara esta convivencia entre toda la comunidad hispana que pertenece a la parroquia.

Aunque esta celebración en Turlock surge principalmente de las prácticas religiosas locales de Jalostotitlán, la asociación no la considera solamente como fiesta de Jalos. Más bien, es la tradición de su tierra natal, y a la vez, la fiesta de la iglesia del Sagrado Corazón de Turlock para todos los hispanos.

El 2003 fue un año muy significativo para los integrantes de la Asociación de Nuestra Señora de la Asunción porque llegó a Turlock una réplica de la imagen de la Virgen de la Asunción de Jalostotitlán.

Esta réplica se hizo con el permiso de ambas parroquias, es decir, de la parroquia de Turlock y la de Jalostotitlán. Posteriormente, la nueva réplica se trasladó en avión hasta Tijuana. Los integrantes de la Asociación fueron a recogerla a Tijuana para pasar la frontera. Luego, se trasladó esta imagen a Turlock por tierra. Esta vez, la imagen de la Virgen no cruzó la frontera de manera indocumentada, sino que entró a California con todos los documentos necesarios para pasar la aduana. Esta réplica es una copia idéntica de la imagen original de la Virgen de Jalos. Los integrantes tratan de realizar las prácticas religiosas dedicadas a la imagen de la Virgen de la Asunción con la mayor similitud a las de su tierra natal. Por ejemplo, los integrantes hacen el vestido de la Virgen cada año, igual que se hace en su tierra natal. 
De alguna manera, tanto las prácticas religiosas locales de los migrantes como la réplica de la imagen religiosa de su tierra natal fueron apropiadas por la iglesia católica de Turlock como nuevas prácticas religiosas de la población hispana que ha llegado a la ciudad como migrante y su nuevo símbolo, dando nuevos significados a la tradición local de los jalostotitlenses y a la imagen de la patrona de su lugar de origen. Hace unos años, el sacerdote de la iglesia del Sagrado Corazón de Turlock dio el siguiente discurso en la misa en español, explicando la vida de Elías, el profeta de Israel y comparándola con la vida de los migrantes que llegaron a Estados Unidos:

Al hacer la lectura del profeta, pensaba yo, cómo hay diversos motivos por los cuales las personas tienen que emigrar y dejar a sus pueblos, a sus tierras. Las circunstancias por las cuales muchos de ustedes han emigrado a este país del norte, no es la misma circunstancia por la que el profeta Elías también emigraba al país del norte. A ese país, él emigraba por ser perseguido. Las razones son diferentes. Pero [...] el profeta Elías necesitó un alimento para su camino de huída. Igual que quienes emigran siguen necesitando en su vida cristiana de un alimento que nos mantenga en su vida cotidiana. Este profeta Elías, el primer gran profeta de Israel, hace que se vea en él como un regreso a las fuentes de la fe del pueblo, es decir, es una llamada de atención para que el pueblo recuerde su fe. Y por qué no decirlo, también ahora en el contexto de esta lectura, nosotros, al colocar en este lugar la imagen de Nuestra Señora de la Asunción, volvemos a las fuentes de nuestra fe, volvemos a nuestra memoria, nuestro recuerdo, a esos lugares donde algunos de ustedes, muchos de ustedes han peregrinado en algunas ocasiones, a lugares que les vieron nacer, lugares de sus padres, lugares, también, de crecimiento en la fe $[\ldots]^{152}$

Lo que se puede interpretar en este discurso es que la imagen religiosa del terruño de los migrantes de cierta región, fue apropiada por la iglesia de destino como un símbolo que crea en los migrantes hispanos católicos en general las memorias, recuerdos de las costumbres y tradiciones de sus lugares de origen vinculadas de manera estrecha con la religión católica, la fe y la identidad religiosa. De este modo, la iglesia local de destino intenta incorporar a la población migrante hispana a la jurisdicción de la parroquia para buscar el crecimiento de la misma.

Desde el 15 de noviembre de 2004, esta imagen está guardada dentro de la iglesia del Sagrado Corazón en Turlock y sale de ahí el día 15 de agosto para

${ }^{152}$ La película de la Celebración de Nuestra Señora de la Asunción grabado en DVD que hizo la Asociación de Nuestra Señora de la Asunción. 
acompañar la procesión que recorre las calles de la ciudad el mismo día. Para la celebración de esta fiesta religiosa, llegan a Turlock muchos jalostotitlenses que viven en Sacramento, San José, San Francisco, Petaluma, Fresno y otras localidades del norte de California.

Aunque con esta celebración oficial de la fiesta religiosa los jalostotitlenses de Turlock que forman la Asociación de Nuestra Señora de la Asunción han tenido un motivo más para no regresar a su tierra natal en agosto, año con año han hecho esfuerzos para promover las prácticas religiosas que se dan alrededor de esta nueva imagen, creando la página de Internet y distribuyendo imágenes de la celebración del 15 de agosto en Turlock en DVD. Esta película de la fiesta religiosa grabada en DVD se envió a Jalostotitlán y se transmitió en el canal local durante las fiestas patronales de agosto de 2004.

\section{LOS HIJOS AUSENTES Y LA IGLESIA LOCAL DEI LUGAR DE ORIGEN}

En Jalostotitlán, hay varios términos para referirse a los jalostotitlenses que viven en Estados Unidos: emigrante, migrante, norteño y ausente. El primer término es lo que se usa con frecuencia en los folletos de las fiestas patronales de agosto y del carnaval para referirse a esta población desplazada. El segundo no es tan común como el primero. Pero los investigadores de estudios de migración, como yo, lo han usado y algunas personas a veces usan este término que aparece en los estudios académicos y en las noticias de la televisión. La palabra norteño se usa con más frecuencia que los primeros dos términos por los habitantes, pero, tiene una connotación negativa y a veces, se usa para despreciar sus comportamientos que son diferentes de los de los habitantes locales. Ausente o hijo ausente es el término más común que se usa tanto entre los habitantes de Jalos como los migrantes que viven y trabajan en Estados Unidos aunque este término no sólo se refiere a aquellas personas que vivan en Estados Unidos, sino también a los jalostotitlenses y sus familias en general que viven fuera del municipio de Jalostotitlán. Es decir: aquellas personas que se fueron a vivir a otras localidades, ciudades y otros estados de la República Mexicana también son "ausentes". 
En las fiestas patronales de agosto hay una fecha especialmente dedicada a los hijos ausentes, el 16 de agosto. ${ }^{153}$ En este día se celebran la peregrinación y la misa exclusivamente para ellos como ceremonias oficiales de la parroquia de Jalostotitlán.

Antes de las 11:30 de la mañana tanto los ausentes nacionales como los ausentes de Estados Unidos se reúnen en una parte de la Av. Guadalupe González del centro de la cabecera municipal que se encuentra enfrente del complejo deportivo "La Alameda". El encargado del día de los hijos ausentes y algunos ausentes reparten las calcomanías del día de los hijos ausentes a las personas que forman la peregrinación. Encontraba yo, en las veces en que participaba en la peregrinación del día 16 de agosto durante la investigación, a los ex integrantes del Club Social Jalostotitlán de Los Ángeles, repartiendo las calcomanías a la gente.

A las 11:30 de la mañana comienza a avanzar la peregrinación de miles de "hijos ausentes". Por ejemplo, en el año 2003, se prepararon 2000 calcomanías del "día de los ausentes" y sobraron solamente alrededor de 100. Recorren las calles de la ciudad pasando por la Plaza de Armas y la presidencia municipal y llegan al Templo parroquial de Nuestra Señora de la Asunción. A las 12:00 del día comienza la misa. Por lo general, no caben en el templo todas las personas que forman la peregrinación.

Estas ceremonias religiosas ya han sido una tradición que se ha practicado por la iglesia y por los ausentes en las fiestas patronales de agosto, por lo menos, durante casi medio siglo. Por ejemplo, en el programa de las fiestas religiosas de agosto de 1948, en el año en que se realizó la coronación de la Virgen de la Asunción en Jalostotitlán, ya aparece la siguiente indicación: "Día 16. Festividades organizadas por los hijos de Jalostotitlán, radicados fuera de la parroquia."154

${ }^{153}$ Hay otros casos de la celebración de un ritual para incorporar a la población migrante al lugar de origen durante las fiestas religiosas en los Altos de Jalisco. Por ejemplo, en el caso de San Diego de Alejandría, un pueblo de los Altos de Jalisco, el día 8 de enero se celebra el "día del emigrante" en el último día de las fiestas religiosas dedicadas a la Inmaculada Concepción que comienza el 31 de diciembre (Espinosa, 1999).

${ }^{154}$ Padilla (1988: 208). 
Durante el trabajo de campo realizado en Jalostotitlán en agosto del 2003, también pude observar la existencia de una oración dedicada a los ausentes. En ese año, se repartieron en los días anteriores al 16 de agosto las tarjetas de invitación del "día de los ausentes" para dar la información a los jalostotitlenses que vivían fuera de la población. Se les informaba sobre el horario de la peregrinación y la misa del 16 de agosto y otros eventos religiosos y civiles. La tarjeta de invitación del 2003 tiene un mensaje del presidente municipal dirigido a los ausentes, el programa de las ceremonias religiosas y eventos relacionados con los ausentes, tales como, convivio de los hijos ausentes en el Salón Pío XII del templo parroquial y las ceremonias del día 16 de agosto. En ese programa, también aparece una "oración por los emigrantes":

Oh, Jesús, te pido por todos aquellos que andamos lejos de la Patria y vivimos la experiencia de la emigración. Somos hermanos en búsqueda de un mundo mejor.

Tú mismo te identificas con nosotros, porque viviste la dura prueba del exilio en Egipto, junto con María, tu Madre, y con José.

Todos necesitamos un trabajo que asegure el sustento de la familia. Pero también necesitamos de tu palabra de vida, para no perder los valores de nuestra cultura y fe.

Oh corazón de Jesús, bendice a los emigrantes, guárdanos junto a tu corazón. Llena nuestras vidas con el amor de Dios, quien es el principio de todo bien.

Que como peregrinos de la Iglesia de Dios, podamos alcanzar la ciudad celestial y disfrutar todos juntos, la vida eterna para siempre. Amén. ${ }^{155}$

Asimismo, hay invitaciones a las fiestas patronales que llegan directamente desde Jalostotitlán a los domicilios de los ausentes en Estados Unidos. La parroquia de Jalostotitlán envía cada año el programa de las fiestas de la Virgen de la Asunción y una carta del párroco a las direcciones de domicilios de los ausentes registradas por la parroquia, para invitarlos a esta celebración de la patrona de su lugar de origen. Por ejemplo, en el año 2004, la iglesia envió la invitación a 364 direcciones: 25 direcciones eran de otras ciudades del interior del país, tales como, Ciudad de México, Guadalajara, Monterrey, Tijuana, Torreón; el resto era direcciones de distintas localidades, condados y estados de Estados Unidos, aunque la mayoría de las direcciones eran de varias localidades de California. ${ }^{156}$

${ }^{155}$ Invitación del 16 de agosto "Día de los Ausentes", 2003.

${ }^{156}$ La lista de direcciones de domicilios de los ausentes registradas en la iglesia no necesariamente demuestra la totalidad de las familias migrantes originarias de Jalostotitlán 
El envío de la invitación de las fiestas religiosas de agosto de Jalostotitlán no sólo les ha servido a los ausentes para enterarse de los eventos que se celebran durante las fiestas patronales, sino para mantener y fortalecer un vínculo emocional con su tierra natal porque cuando los ausentes reciben el programa y la carta de invitación, se emocionan y empiezan a conversar y compartir sus recuerdos de las fiestas patronales con sus familias.

El intento por parte de la iglesia de Jalostotitlán para crear y reforzar el vínculo con los ausentes no sólo consiste en la celebración del día de los hijos ausentes el 16 de agosto y el envío del programa y la invitación a esta población desplazada al país del norte, sino en la "reinvención de tradición" para que los ausentes puedan estar vinculados simbólicamente con la parroquia de su tierra natal y mantener las prácticas religiosas locales a pesar de estar distantes de su lugar de origen. ${ }^{157}$ Hasta mediados de los años ochenta, en Jalostotitlán había la costumbre de recibir la bendición a las 9:00 de la noche todos los días. Cuando sonaba la campana del templo parroquial, donde quiera que estuvieran, las personas tenían que arrodillarse o guardar silencio. Pero esta costumbre se suspendió por la decisión del párroco que estuvo en Jalos entre los años ochenta y los años noventa. El nuevo párroco que llegó a Jalos, quien estuvo en la parroquia durante los primeros años de este siglo reestableció esta práctica dando un nuevo significado: cuando suena la campana a las 9:00 de la noche (hora de Jalostotitlán), donde quiera que estén los jalostotitlenses pueden recibir la bendición. La bendición va a donde quiera que se encuentren los jalostotitlenses. Aunque estén en California, pueden recibir la bendición a las 7:00 de la noche de California (que son las 9:00 de la noche de Jalos).

radicadas en Estados Unidos ni la totalidad de la distribución geográfica de los migrantes en ese país porque no todos los ausentes que regresan a Jalos para las fiestas de agosto han entregado las direcciones de sus domicilios.

${ }^{157}$ En cuanto a la noción de "invención de tradición", véase Hobsbawm y Ranger (1983). El tema principal de su texto es deconstruir la idea de que las "tradiciones" son aquellas prácticas sociales, religiosas o culturales que han existido desde el pasado inmemorial sin cambio alguno. Las prácticas sociales y culturales que se etiquetan como "tradiciones" son, en realidad, el producto de la selección de los componentes y formas de las prácticas para adaptarlas al contexto político, económico, social y cultural de cada época. Sin embargo, me parece que el término "invención" resulta una connotación un poco agresiva para las personas que participan en las prácticas sociales y culturales locales dando significados importantes a ellas en su vida y a su conservación. 
De cierta manera, la reincorporación de los ausentes radicados en Estados Unidos a la parroquia de su lugar de origen ha sido sumamente importante en las últimas décadas para el desarrollo de la parroquia. En la parroquia de Jalostotitlán existen varios templos e iglesias que fueron remodelados y construidos con una gran cantidad de recursos económicos que han donado los migrantes. Por ejemplo, la construcción reciente del Templo del Padre Toribio Romo fue posible en parte por la colaboración de los ausentes en Estados Unidos porque se recolectó la donación por medio de un comité que algunos migrantes formaron para ayudar a la construcción del nuevo templo después de recibir en California en 1996 la visita del párroco de Jalostotitlán, quien trataba de promover la devoción por el Padre Toribio y la construcción de su templo entre los ausentes.

\section{SANTO TORIBIO ROMO Y LA PEREGRINACIÓN EN SANTA ANA DE GUADALUPE}

Toribio Romo González nació el 16 de abril de 1900 en Santa Ana de Guadalupe, la población que pertenece al municipio de Jalostotitlán. Después de estudiar la primaria en Jalostotitlán, ingresó al seminario auxiliar de San Juan de los Lagos en 1913. En 1920 terminó sus estudios en San Juan de los Lagos, pasó al seminario de Guadalajara y fue ordenado sacerdote en 1922. Después de haber realizado su servicio sacerdotal en diferentes parroquias del Estado de Jalisco, llegó a Tequila en septiembre de 1927, un año después del levantamiento del movimiento cristero en el occidente de México. Este conflicto por la cuestión religiosa surgió como una respuesta por parte de los católicos a la expulsión de los sacerdotes extranjeros, la clausura de las iglesias y la prohibición de actividades religiosas que ordenó el gobierno federal de Calles.

En Tequila realizaba sus actividades sacerdotales escondiéndose, dado que el ejército federal perseguía a los sacerdotes y a los feligreses cristeros. El 25 de febrero del 1928, los soldados federales y agraristas lo descubrieron y lo asesinaron. Esta es la breve biografía de este mártir cristero. ${ }^{158}$

${ }^{158}$ Esta breve biografía de Toribio Romo está basada en el artículo de Guzmán Mundo (2004: 123-125, 130-133) y la revista local de Jalostotitlán, Mi Tierra, No.1, junio del 2000, Jalostotitlán., pp. 2-6. 
En 1992 se realizó la beatificación del padre Toribio Romo y posteriormente, el 21 de mayo del año 2000 se le canonizó junto con otros 24 mártires cristeros en el Vaticano. El padre Toribio Romo González es uno de los santos mexicanos más conocidos en el país y también en Estados Unidos. Se le conoce popularmente como el Santo protector de los migrantes indocumentados, "Patrono de los mojados", "Santo pollero" o "Santo Coyote". 159

Santa Ana de Guadalupe tiene cerca de 400 habitantes. Hasta hace dos décadas había sido una ranchería aislada del exterior que se podía entender con el concepto convencional antropológico de "comunidad" aunque había tenido contacto con el mundo exterior desde el siglo XVII por medio del comercio, envío de sus hijos a seminarios e hijas a los conventos y la migración hacia Estados Unidos. ${ }^{160}$ Después de la guerra cristera, Santa Ana de Guadalupe había sido una comunidad olvidada y relativamente autónoma. Una de las razones fue porque sus habitantes habían tomado una postura de autoaislamiento con el exterior, sobre todo, con los proyectos gubernamentales. Apenas en la segunda mitad de los años ochenta, se instaló la electricidad en esta población, lo cual fue el primer proyecto gubernamental que aceptaron los habitantes de Santa Ana de Guadalupe. Sin embargo, en la última década, esta población ha demostrado un rápido crecimiento y se ha abierto mucho más con las personas que vienen de fuera. Hace más de una década, en Santa Ana vivían unos 100 habitantes. Pero el número de la población creció y ahora tiene cerca de 400 habitantes. Ante este crecimiento de la población y desarrollo del lugar, Santa Ana subió su categoría de ranchería a agencia.

El crecimiento y la apertura de Santa Ana de Guadalupe tienen que ver con la peregrinación de los devotos de Santo Toribio Romo a su santuario. Los fines

${ }^{159}$ Marco A. García Gutiérrez, 2002, "Toribio Romo González: Protector de los mojados", Contenido, 1 de junio; Luis Alfonso Orozco, 2005, "Toribio Romo González, Santo. El santo protector de los 'mojados', en Luis Alfonso Orozco (ed.), Madera de Héroes: semblanza de algunos héroes mexicanos de nuestro tiempo, México, Arca; Pedro Baca Montaño, 2003, "Toribio Romo. Santo coyote de los braceros", en Revista bi: revista del México binacional, 1 (3), pp. 11-13.

${ }^{160}$ Regina Martínez Casas y Guillermo de la Peña, 2004, "Migración y Comunidades Morales", ponencia presentada el 14 de mayo de 2004, el Gobierno del DF. 
de semana llegan miles de peregrinos. ${ }^{161}$ Por ejemplo, cuando hice trabajo de campo en un domingo de Semana Santa del año 2004, llegaba un gran número de personas en camiones de excursión y coches. En los estacionamientos ubicados en la entrada del centro de la población, había una docena de camiones de excursión de Aguascalientes, Guadalajara y de otros lugares del Estado de Jalisco. Por ejemplo, algunos camiones procedentes de Aguascalientes llevaban a los turistas de Aguascalientes, Guanajuato, Michoacán, Ciudad de México y otros lugares que hacían un día de excursión entre Aguascalientes, Santa Ana de Guadalupe, San Juan de los Lagos y otros lugares. También había coches y camionetas con las placas de Zacatecas, Jalisco, Baja California, Aguascalientes, Michoacán, Guanajuato, Tamaulipas y de otros estados del país del norte, tales como, California, Texas, Illinois, Oklahoma. ${ }^{162}$

En las cartas y retablos que dejaron en el santuario los peregrinos procedentes de diversas partes del interior del país y de Estados Unidos, pude observar diferentes milagros por los que ellos daban gracias al Santo y hacían peticiones. Algunos le pedían su protección y le daban agradecimiento por su ayuda en los momentos difíciles de su vida, tales como, enfermedad, operación y acusaciones. Otros le pedían y agradecían por favores relacionados con las experiencias migratorias. Por ejemplo, "gracias por habernos ayudado a llegar con bien a los Estados Unidos", "Vine a pedirle que me ayude a pasar a Los Ángeles", "gracias por haberme hecho el milagro de que llegáramos a nuestro destino Texas yo y todos mis compañeros", "Gracias por salvarlo en el desierto de Estados Unidos", "gracias por librarse de un accidente en Los Ángeles", "Gracias por tener este hogar con tu ayuda después de andar tanto tiempo por Estados Unidos".

${ }^{161}$ Según el artículo del periódico The Orange County Register, que se publicó el 1ro de junio de 2003, el número de los peregrinos es más de 5000 todos los fines de semana. En el artículo de Marco A. García Gutiérrez (2002), aparece el número de camiones que llevan peregrinos a Santa Ana de Guadalupe cada sábado y domingo: es más de 50 .

${ }_{162}$ Hay dos razones importantes por las cuales la mayoría de peregrinos vienen de los estados del occidente y norte del país: en primer lugar, algunos de estos estados son las regiones que fueron principales escenas de la guerra cristera; en segundo lugar, porque son estados que aportan a la migración hacia Estados Unidos. 
La transformación de Santa Ana de Guadalupe como un destino de peregrinación en los años recientes después de la canonización del mártir de la guerra cristera ha contribuido al desarrollo de la iglesia local y de la población. En primer lugar, por medio de la venta de imágenes religiosas, llaveros del Santo Toribio y otros tipos de productos en las colecturías del santuario, la iglesia local ha tenido mejor ingreso económico. En segundo lugar, la llegada de miles de peregrinos ha fomentado el comercio local, como negocios locales de abarrotes, restaurantes, puestos de bebida, coctel de frutas y de artesanías y estacionamientos privados. De alguna manera, el comercio local relacionado con la peregrinación ha creado entre los habitantes fuentes de trabajo alternativo a la ganadería, la agricultura y la migración. Por ejemplo, don José, originario de Santa Ana de Guadalupe, en su trayectoria laboral, primero se dedicaba a la ganadería en esta población. Luego se fue a trabajar a Jalostotitlán. Después, se fue al Norte como muchas de otras personas de Santa Ana; estuvo trabajando en Santa Mónica durante un año. Después de haber regresado a México, trabajaba para una empresa de producción de pan y posteriormente para una empresa cigarrera. En el año 2000, puso un negocio de carnitas; el negocio creció rápidamente. Ahora, en los fines de semana, prepara casi 1000 kilos de carnitas, y tiene entre 15 y 20 empleados.

La peregrinación también ha contribuido al desarrollo material de la población. Se remodeló la iglesia y se construyó la calzada de los mártires de la guerra cristera en la capilla. Se han pavimentado las principales avenidas y hay un proyecto de ampliación del camino a Santa Ana de Guadalupe. En el año 2000, se levantó un arco monumental de cantera rosa con la ayuda de un grupo de migrantes zacatecanos devotos del Santo Toribio. ${ }^{163}$

Otro impacto positivo de la peregrinación es el mejoramiento de la imagen de Santa Ana de Guadalupe. Tradicionalmente sus habitantes habían sufrido de prejuicios y discriminación dentro del municipio. Pero ahora gracias a la popularidad del Santo Toribio Romo, las imágenes negativas de Santa Ana y la

${ }^{163}$ García Gutiérrez (2002); Orozco (2005). 
mentalidad de sus habitantes han cambiado. Ahora con orgullo pueden representar su identidad local.

Hay algunos factores fundamentales por los cuales han surgido esta peregrinación y la popularidad del Santo Toribio entre los migrantes. En primer lugar, el auge de la creencia popular en este nuevo santo mexicano tiene que ver con varios testimonios y anécdotas de milagros. Hace dos décadas, un campesino zacatecano decidió irse de manera indocumentada a California para buscar trabajo. Hizo contacto con un "pollero" en Mexicali, pero al cruzar la frontera, la patrulla fronteriza los descubrió y el zacatecano se metió en el desierto para escapar. Después de caminar días en el desierto sufriendo calor y sed, vio una camioneta que se acercaba hacia él. Salió del vehículo un hombre de apariencia juvenil que hablaba español. Le ofreció agua, alimento y le prestó unos dólares. Al despedirse, le dijo al migrante que cuando tuviera dinero y trabajo, lo buscara en Jalostotitlán, Jalisco y preguntara a la gente por Toribio Romo. Después de haber trabajado durante una temporada en California, el migrante regresó a México y decidió visitar a Toribio. Cuando llegó a Jalostotitlán, lo mandaron a Santa Ana de Guadalupe. Cuando preguntó a la gente por Toribio Romo, le dijo que estaba en el templo. Cuando vio una imagen de ese joven que lo ayudó en el desierto en el altar mayor, casi le daba un infarto. Ese hombre había sido un mártir de la guerra cristera muchos años atrás. ${ }^{164}$ Muchos testimonios de los migrantes mexicanos indocumentados como este han convertido al padre Toribio Romo en un santo protector de los indocumentados.

Otro factor importante es la situación actual de la frontera. La popularidad creciente de este santo corresponde a la situación reciente en la que han muerto más migrantes en el proceso de "militarización" de la frontera entre México y Estados Unidos. A diferencia del cruce fronterizo del tiempo atrás, los migrantes indocumentados tienen que correr más riesgo al cruzar la frontera debido a que los puntos más fáciles para cruzar la frontera están más vigilados y tienen que pasar por puntos geográficamente difíciles, tales como, el río de la corriente rápida y los desiertos abiertos.

${ }^{164}$ García Gutiérrez (2002). 
Aparte de estos dos factores, el papel que ha jugado el padre Gabriel González Pérez, quien ha estado en la iglesia local durante años, ha sido clave para el desarrollo de la iglesia de la población, y la difusión de la creencia popular en el Santo Toribio. Por ejemplo, este sacerdote tomaba la iniciativa en Santa Ana de Guadalupe para promover el comercio local. Les decía a los habitantes que no había suficientes sitios para comer y que antes de que llegara la gente de fuera a invertir en los negocios relacionados con la peregrinación, los habitantes mismos comenzaran a poner los negocios para recibir a tantos peregrinos. Les pedía a sus feligreses que en el caso de que abrieran negocios, se mantuviera la calidad del producto y del servicio y no alzaran el precio para los peregrinos. También invitó a la empresa maquiladora de ropa deportiva que tiene sede en los Altos de Jalisco para abrir una microsucursal cerca de la iglesia. En la tienda se venden productos de "outlet". Las ganancias por la venta de los uniformes deportivos se destinan a ayudar a la iglesia para cubrir los gastos de construcción y remodelación de sitios sagrados.

Los medios de comunicación también han jugado un papel fundamental para la difusión de la fama de Santo Toribio y de Santa Ana de Guadalupe. La delegación regional de la Secretaría de Turismo del Gobierno de Jalisco, que se encuentra en San Juan de los Lagos, organizó entrevistas y un recorrido turístico para la prensa en 1999, 2001 y 2003. En las entrevistas, el sacerdote Gabriel González hablaba del milagro de Santo Toribio a los periodistas de los estados vecinos. Por medio de estos periodistas, se difundió rápidamente la fama de Santo Toribio como patrón de los migrantes indocumentados entre los colegas de otros países. Llegaron periodistas de Los Ángeles, Chicago, Miami y de programas de radio y televisión de Estados Unidos.

El último factor importante es que la peregrinación en Santa Ana de Guadalupe se ha promovido dentro del proyecto regional de turismo. La Secretaría de Turismo del Gobierno de Jalisco planteó como el proyecto del turismo en los Altos de Jalisco el proyecto llamado "Ruta Cristera". ${ }^{165}$ La primera etapa del

${ }^{165}$ La información acerca de este proyecto regional se debe a la entrevista realizada el 20 de abril de 2004 con el Mtro. Silvano Ruezga, quien estaba, en el momento de la entrevista, en el cargo de delegado del proyecto del turismo regional desde que comenzó la 
proyecto se centraba en la explotación y la promoción de la ruta cristera para traer a la gente a los Altos de Jalisco. Por ejemplo, la organización de entrevistas y el recorrido para la prensa era una de las estrategias en esta etapa del proyecto. En la segunda etapa, en la que se encuentra ahora, se busca la distribución de turistas, recursos y beneficios del turismo regional a 25 municipios de los Altos de Jalisco. Cada uno de los lugares que componen la ruta cristera tiene sus propias características y atracciones turísticas. Por ejemplo, la catedral es la atracción principal de San Juan de los Lago, la artesanía de Teocaltiche, los textiles de Villa Hidalgo, la arquitectura de estilo colonial de Lagos de Moreno, el tequila de Arandas, etc.

Por su ubicación geográfica, la región alteña no puede plantear un proyecto turístico de playa y sol. Pero el Mtro. Silvano Ruezga, profesor de turismo de la Universidad de Guadalajara y encargado del proyecto de la Ruta Cristera, explicó que el turismo religioso tiene ciertas ventajas. Mientras que el turismo de playa y sol depende mucho de la situación política y económica de las sociedades emisoras de turistas, el turismo religioso permite buscar el flujo de turistas en cualquier situación, dado que en los momentos difíciles la gente va a los santuarios a pedir la solución de problemas y preocupaciones, y cuando no hay problemas en las sociedades emisoras, viaja para dar gracias a los santos y a la Virgen. De alguna manera, las creencias que tienen los mexicanos y los católicos en general en la religión y el fuerte apego a la iglesia son recursos importantes para el turismo religioso.

La peregrinación en Santa Ana de Guadalupe se inserta en este proyecto del turismo regional. En la ruta cristera, esta población es un punto importante para el turismo religioso regional porque está geográficamente cerca de San Juan de los Lagos y porque es el lugar de nacimiento y tiene santuario de uno de los santos más populares de los mártires de la guerra cristera.

Aunque la cabecera municipal está ubicada cerca de Santa Ana de Guadalupe, la creencia que tienen los jalostotitlenses en el padre Toribio Romo es reciente. De hecho, antes de la beatificación de este mártir de la guerra cristera en 
1992, muchos de los habitantes de Jalostotitlán no lo conocían. Pero en la última década, la devoción por el padre Toribio se difundió entre los habitantes por medio de su canonización en el año 2000 y la construcción del Templo dedicado al Santo Toribio dentro de la cabecera municipal. Ahora los jalostotitlenses se han apropiado de la creencia en él. Se venden sus imágenes y llaveros en la notaría del Templo parroquial de Nuestra Señora de la Asunción y los productos con la imagen de este santo en las tiendas de artículos de recuerdos de viaje a Jalos. Hay negocios con el nombre de "Padre Toribio" y muchos niños recién nacidos que se llaman Toribio.

Los ausentes en Estados Unidos también se han apropiado de la creencia en este Santo. Por medio del viaje que hizo el párroco de Jalostotitlán al sur de California en 1996, de la formación de un comité para ayudar a la construcción del nuevo templo en California y del retorno temporal a su tierra natal, se ha difundido rápidamente la popularidad del padre Toribio entre los jalostotitlenses radicados en Estados Unidos. Algunos migrantes jalostotitlenses guardan la imagen de Santo Toribio en su cartera para pedir su protección en el camino al Norte y en la vida en Estados Unidos. Otros llevan su imagen en playeras y llaveros para ellos o para sus familiares cuando se van de Jalos hacia el Norte. Hace años, una señora originaria de Jalostotitlán obsequió la imagen del padre Toribio Romo a la iglesia de San Bonifacio en Anaheim, una de las iglesias donde los ausentes han celebrado la fiesta de la Virgen de la Asunción. Actualmente esta imagen está colocada en el altar de la iglesia junto con la imagen de la Virgen de Guadalupe.

El comerciante que vende llaveros y playeras con la imagen del padre Toribio en Jalostotitlán me contó un chiste que se cuenta en Jalos en los años recientes. Un hombre le pregunta a su amigo: “ ¿Te vas al Norte sin papel?" Su amigo contesta: "Pero tengo la imagen de Toribio Romo". El hombre dice: "¡Ya la hiciste! Con esta imagen puedes cruzar la frontera sin problema."

\section{CONCLUSIONES}

En este capítulo, he descrito diferentes casos etnográficos sobre las prácticas religiosas de los migrantes que se caracterizan por la inserción de las imágenes 
sagradas de su terruño y la devoción local por ellas tanto en el país receptor como en el contexto transnacional. Lo que quise demostrar a través del análisis de los tres primeros casos etnográficos es, en primer lugar, que hay diferentes modos de vivir el tiempo y espacio ritual entre los jalostotitlenses. El tiempo y espacio ritual que viven los jalostotitlenses varían dependiendo del lugar de residencia, el trabajo, el estatus legal, la situación económica, los compromisos familiares y el contexto social y político. Los habitantes de Jalostotitlán no tienen dificultad para vivir según el calendario religioso. Pero los ausentes que viven en Estados Unidos han tenido que desafiar la distancia física que los separan de su terruño para poder participar en la celebración de las fiestas de la Virgen de la Asunción en Jalostotitlán. Ante esta situación, los migrantes jalostotitlenses radicados en Estados Unidos han creado diferentes prácticas espaciales para poder participar, en distintas formas, en el ritual más importante para los jalostotitlenses.

Para aquellos migrantes que, por distintos motivos, tienen dificultad para estar físicamente en su terruño en agosto saliendo de la vida cotidiana en el país receptor, se han organizado las fiestas patronales en los lugares de destino en California como demuestran los primeros dos casos etnográficos. Las réplicas de la imagen de la Virgen de la Asunción, que fueron llevadas de Jalostotitlán a California cruzando la frontera, jugaron un papel fundamental en el desarrollo de estas prácticas religiosas de la localidad de origen, reterritorializadas en California. La lógica de la inserción de los símbolos religiosas locales en los lugares de destino es que si los migrantes no pueden regresar a Jalostotitlán para las fiestas patronales, la imagen de la Virgen de la Asunción viene hacia ellos para que puedan estar simbólicamente conectados con las fiestas religiosas celebradas en Jalostotitlán.

Otra práctica espacial de los migrantes para desafiar la distancia física entre el país receptor y el terruño con el fin de participar en las fiestas patronales de Jalostotitlán, es viajar físicamente al terruño como demuestra el tercer caso etnográfico. En este caso, se puede interpretar que el retorno temporal de los migrantes en sí es una peregrinación, como había comentado en el capítulo 2, 
porque en la primera quincena de agosto su terruño se convierte en un lugar sagrado y porque uno de los motivos principales de este viaje es religioso.

La segunda implicación de los tres primeros casos etnográficos que quisiera destacar, es que detrás del surgimiento y el desarrollo de estas prácticas religiosas, hay sentimientos de los migrantes hacia el ritual de su terruño. Para entender los sentimientos de los migrantes que sustentan estas prácticas religiosas populares de los migrantes, cabe recordar las implicaciones que tiene para los migrantes el hecho de no poder regresar a su terruño en la temporada de fiestas patronales, las cuales expliqué en el capítulo 2. Para ellos, el no poder estar en estas fiestas significa la pérdida de una oportunidad para reafirmar la identidad religiosa y el sentido de pertenencia a Jalostotitlán cuyo símbolo central ha sido históricamente la Virgen de la Asunción; la alienación del tiempo y el espacio en cuanto a la alegría que pueden sentir al reencontrar a sus seres queridos y festejar con ellos, en este período del año, a la Virgen de la Asunción; la pérdida de una oportunidad para liberarse de la cotidianeidad sujeta al trabajo y a las normas sociales en Estados Unidos; la pérdida de una oportunidad para liberarse de la posición social como seres subalternos en la sociedad receptora, y la pérdida de oportunidades para reforzar lazos sociales con los habitantes del lugar de origen. Por lo tanto, la tristeza y la nostalgia prevalecen en la vida de los migrantes en esta temporada.

Sin embargo, como demuestran los primeros tres casos que presenté en este capítulo, los migrantes han encontrado en la inserción de las réplicas de la imagen sagrada y las prácticas religiosas de su terruño en la sociedad receptora y en el retorno temporal en agosto, formas para evitar que el mes de agosto sea el período más nostálgico del año en el calendario emocional y para sincronizar sus emociones con la alegría colectiva que surge de las fiestas religiosas de Jalostotitlán.

Los sentimientos hacia el símbolo religioso, el lugar sagrado y el ritual, que les dan a los jalostotitlenses la identidad religiosa, el sentido de pertenencia y otros sentidos de vida, no sólo han sido los motores del surgimiento y el desarrollo de estas prácticas religiosas de los migrantes, sino que también han contribuido 
de manera importante a la construcción, el mantenimiento y el fortalecimiento de las conexiones transnacionales sociales, simbólicas y emocionales entre el país receptor y el terruño a través de estas prácticas religiosas. Éstas han creado y fortalecido el vínculo social entre los migrantes y su terruño a través de los flujos transfronterizos de personas, objetos o símbolos religiosos. Además, como demuestran el caso de las prácticas religiosas de los migrantes en el sur de California y en Turlock, la inserción de las prácticas religiosas y de la réplica de la imagen de la parroquia del lugar de origen de los migrantes en la sociedad receptora ha contribuido, de una manera sumamente importante, al mantenimiento y el reforzamiento de lazos sociales entre los migrantes jalostotitlenses.

Además de las conexiones transnacionales sociales, la devoción por la imagen sagrada del terruño, los símbolos y las prácticas religiosas locales que migraron a California y la identidad religiosa y social que se reafirman a través del retorno temporal, han construido los circuitos simbólicos y emocionales entre la sociedad emisora y la receptora. En estos circuitos simbólicos y emocionales transnacionales, y en relación con la dimensión religiosa de la vida de los migrantes, su terruño se convierte en el punto central o el lugar de origen, porque es el lugar de donde surgen la devoción por la Virgen de la Asunción, sus réplicas que viajaron a California y las prácticas religiosas de los migrantes, pero además porque es el lugar que sus sentimientos hacia la imagen sagrada, el lugar sagrado y el ritual del terruño convierten en el centro del valor simbólico dentro de estos circuitos transnacionales. Esta centralidad simbólica y emocional del lugar de origen se observa, por ejemplo, en el hecho de que el premio de la rifa que se hizo en las fiestas patronales celebradas en el sur de California fue un boleto para viajar a Jalostotitlán y en el hecho de que muchos migrantes viajan a Jalostotitlán en vez de participar en las fiestas patronales celebradas en sus lugares de residencia cuando su condición económica, el estatus migratorio y sus compromisos laborales y familiares les permiten regresar temporalmente a su terruño.

Sin embargo, las conexiones transnacionales de la dimensión religiosa de la vida de los migrantes no sólo surgen de las prácticas religiosas populares 
desarrolladas por la iniciativa de los migrantes. El vínculo entre los migrantes y el lugar de origen tampoco se ha construido y fortalecido de manera unilateral por las prácticas religiosas de los migrantes. El desarrollo de estas prácticas religiosas populares de los migrantes y la construcción y el fortalecimiento de las conexiones transnacionales en la dimensión religiosa también tienen que ver con la intervención en estos procesos por parte de las iglesias locales que se encuentran en ambos lados de la frontera y con sus prácticas religiosas institucionales, a través de las cuales las iglesias pretenden acercarse a los migrantes como nuevos sujetos religiosos para el desarrollo de sus parroquias.

Por ejemplo, las fiestas patronales de la Virgen de la Asunción organizadas por los migrantes jalostotitlenses se han celebrado en las iglesias católicas de las ciudades asentadas por los migrantes. Esto implica que en estas prácticas religiosas de los migrantes, la incorporación de los migrantes a las parroquias locales de destino y las conexiones simbólicas y emocionales transnacionales con el terruño y sus habitantes con quienes los migrantes comparten una identidad religiosa, se dan al mismo tiempo y se refuerzan entre sí. Esta "simultaneidad" que se caracteriza por "el llevar una vida que incorpora las instituciones, las actividades y las rutinas diarias que se sitúan tanto en el país de destino como transnacionalmente" (Levitt y Glick Schiller, 2004: 62), se observa de manera más notoria en el caso de la fiesta de la Virgen de la Asunción en Turlock. Aunque para los migrantes jalostotitlenses el motivo principal de la celebración de la fiesta dedicada a la Virgen de la Asunción el 15 de agosto en Turlock ha sido conservar las prácticas religiosas del terruño y transmitir sus tradiciones y costumbres a las nuevas generaciones, este ritual también se celebra como una fiesta religiosa oficial de la parroquia de Turlock. Lo que se incorporó a la parroquia local no sólo fueron la réplica de la imagen de la Virgen de la Asunción de Jalostotitlán y sus prácticas religiosas del terruño, sino también los migrantes jalostotitlenses. En este sentido, los migrantes jalostotitlenses participan en esta fiesta religiosa como los fieles que mantienen el vínculo simbólico con las fiestas patronales y la imagen original de la Virgen de la Asunción de su terruño, y al mismo tiempo, como los feligreses de la parroquia de destino. 
Sin embargo, la apropiación de las prácticas religiosas y la imagen sagrada del terruño por parte de cierto grupo de los feligreses en la iglesia de destino tiene mucho que ver con el interés de ésta en acercarse a la población migrante hispana de la ciudad de Turlock. La iglesia de destino institucionaliza las prácticas religiosas y la imagen sagrada del terruño de los migrantes jalostotitlenses, resignificándolas. La imagen religiosa del terruño de los migrantes de cierta región de México se reinterpreta por la iglesia de destino como un símbolo que refuerza la fe y la identidad religiosa que también habían tenido otros migrantes hispanos en sus lugares de origen. Las prácticas religiosas locales de los jalostotitlenses fueron apropiadas como nuevas prácticas religiosas que les permiten a los migrantes hispanos de Turlock regresar de manera simbólica a sus propios terruños. Aunque la iglesia de destino crea un mito de retorno al terruño como fuente de la fe católica, lo que pretende a través de este discurso sobre terruños de los migrantes, no es que los migrantes regresen a sus lugares de origen para acercarse a lo sagrado, sino que al contrario, se acerquen y se incorporen a la parroquia de su lugar de destino porque ahí es donde ellos pueden recuperar las costumbres y tradiciones de sus terruños ligadas a la religión y la fe y volver al tiempo y espacio sagrado de sus terruños de manera simbólica sin salir del país receptor. En otras palabras, a través de la resignificación del símbolo y las prácticas religiosas locales del lugar de origen de los migrante jalosotitlenses y el uso del discurso sobre terruños, la iglesia de destino intenta incorporar a la población migrante a la parroquia de destino.

Pero los migrantes no son potenciales fieles sólo para la iglesia de destino, sino también para la iglesia de origen. Como demuestra el tercer caso etnográfico, para reincorporar a sus feligreses desplazados al exterior de la jurisdicción de la parroquia, la iglesia local ha reinterpretado los rituales y otras prácticas religiosas locales más allá del contexto local y ha modificado y reinventado las tradiciones. La devoción por la imagen sagrada y las prácticas religiosas del terruño que los migrantes siguen conservando en Estados Unidos, también son un capital cultural sumamente importante, para la iglesia de origen, para buscar el desarrollo de la parroquia local. 
La intervención por parte de la iglesia del país de origen en la inserción y la difusión de los símbolos religiosos locales y la devoción por ellos también se observa en el caso de la peregrinación de los migrantes mexicanos en el lugar de nacimiento de Santo Toribio Romo. Originalmente el padre Toribio Romo ha sido una figura religiosa regional de la guerra cristera. Pero la creencia popular de los migrantes mexicanos que surgió de las experiencias vividas de algunos migrantes mexicanos en el desierto fronterizo y las preocupaciones de miles de migrantes por el cruce fronterizo y por la vida migratoria en Estados Unidos, ahora lo sitúan tanto en la frontera como más allá de los límites nacionales y lo han convertido en el Santo protector de los migrantes indocumentados. Pero la resignificación de esta figura religiosa y la difusión de la devoción por él tanto en México como en Estados Unidos también tienen que ver con la intervención del sacerdote de la iglesia de Santa Ana de Guadalupe quien vinculó a esta figura regional del mártir de la guerra cristera con los testimonios de las experiencias milagrosas que tuvieron algunos migrantes indocumentados en las entrevistas con los medios de comunicación que tienen cobertura de transmisión de información en las regiones con una larga tradición migratoria y en la comunidad hispana en Estados Unidos.

La complejidad de la peregrinación en Santa Ana de Guadalupe es que en esta práctica religiosa de los migrantes, se observan la penetración de las fuerzas económicas y políticas a la dimensión religiosa, el entrecruzamiento con la dimensión turística y la intervención de múltiples actores. Además de los migrantes y la iglesia, el proyecto de turismo regional del gobierno del Estado de Jalisco, la inserción del sector comercial en la peregrinación y las políticas del control fronterizo del estado norteamericano y los medios de comunicación también juegan un papel sumamente importante en la construcción y difusión de la devoción por este santo mexicano y en el auge de la peregrinación en su tierra natal.

En este caso de la peregrinación de los migrantes mexicanos en Santa Ana de Guadalupe, se puede observar la transnacionalidad en varios niveles. En primer lugar, los devotos son aquellos que cruzaron los límites territoriales del estado-nación o intentan hacerlo o sus parientes. En segundo lugar, la manda que 
los devotos piden y pagan a este santo está relacionada estrechamente con el acto del cruce fronterizo. En tercer lugar, la difusión de la devoción por esta figura religiosa y el desarrollo de la peregrinación son un proceso transnacional. En cuarto lugar, la peregrinación por la devoción por el Santo Toribio Romo es un fenómeno transnacional, dado que se basa en los flujos de gente, símbolos e información que se dirigen al norte de la frontera y regresan al sur. Por último, Santo Toribio Romo mismo es una figura religiosa transnacional, es decir, una figura que desafía al estado-nación. Pues en el nivel regional, el padre Toribio Romo ha sido uno de los símbolos regionales de la guerra cristera que defendían la fe católica y las costumbres regionales arraigadas a ella ante el estado mexicano anticlerical de entonces. ${ }^{166} \mathrm{Y}$ ahora, apropiándose de su nuevo significado que surgió de la creencia popular de los migrantes mexicanos, se ha convertido en una figura que ayuda a los migrantes indocumentados a ir más allá de los límites territoriales nacionales y desafiar a las políticas del control fronterizo del estado norteamericano que ponen en peligro a numerosos migrantes indocumentados.

En suma, la devoción por las imágenes sagradas del lugar y país de origen y la fe católica que viajan junto con los migrantes más allá de la frontera y sus sentimientos religiosos hacia los símbolos religiosos de su terruño y de su país de origen que se forman en sus experiencias del cruce fronterizo y de la vida cotidiana en sus lugares de destino, no necesariamente están libres de otros actores que les rodean tanto en su país de origen como en el país receptor. Sus subjetividades y sus prácticas religiosas son un blanco de las prácticas religiosas de las iglesias locales en ambos lados de la frontera y de las prácticas económicas de otros actores. En los circuitos simbólicos y emocionales transnacionales que se construyen en la dimensión religiosa de la vida de los migrantes a través de sus prácticas religiosas y la intervención por parte de múltiples actores, el mito de terruño como lugar sagrado no sólo se utiliza por los migrantes para el

${ }^{166}$ El antropólogo Fernando Guzmán Mundo hizo un trabajo que analiza el proceso de construcción histórica de la creencia popular en el Santo Toribio Romo en la región de los Altos de Jalisco y considera a este mártir cristero como un símbolo identitario regional (Guzmán Mundo, 2004). 
mantenimiento de las relaciones sociales entre los migrantes y entre ellos y su terruño, para la conservación y transmisión de las costumbres y tradiciones religiosas de su lugar de origen a las siguientes generaciones y para resolver inquietudes y preocupaciones de sus vidas migratorias, sino que otros actores también lo usan como capital social tanto para la incorporación de los migrantes a las parroquias locales en ambos lados de la frontera como para el desarrollo de las iglesias y de la economía local y regional. 


\section{Capítulo 5}

La producción, la venta y el consumo de signos de terruño

\section{INTRODUCCIÓN}

Durante las últimas dos décadas, el mercado de consumidores hispanos en Estados Unidos ha mostrado un crecimiento dramático. El poder adquisitivo de la población hispana en ese país llegó a 540 mil millones de dólares anuales en 2002. Se estima que llegará a 680 mil millones de dólares para $2010 .{ }^{167}$ Este crecimiento del mercado ha sido sustentado por la expansión demográfica de los hispanos en ese país. Según el censo nacional estadounidense, en 1990 la población hispana en Estados Unidos era de 22.4 millones, pero, en 2000 alcanzó los 37 millones cuya mayoría son de origen mexicano. Entre la población migrante hispana y sus descendientes hay una alta demanda de productos y servicios para mantener las costumbres gastronómicas y prácticas sociales y culturales de regiones y países de origen de los migrantes, lo cual les ha ofrecido a los hispanos oportunidades para abrir sus propios negocios. Actualmente, en Estados Unidos, existen alrededor de 1.6 millones de negocios hispanos, $50 \%$ de los cuales son de origen mexicano. ${ }^{168}$ Aunque en los años recientes, esta potencial capacidad del mercado ha despertado el interés de las grandes empresas estadounidenses y mexicanas, las pequeñas y medianas empresas de los hispanos representan la mayoría de productores y proveedores de este mercado.

Lo que se consume en este mercado son productos étnicos y de la nostalgia. Según un estudio de la CEPAL (Comisión Económica para América Latina y el Caribe), productos de nostalgia se refieren a aquellas mercancías que están integradas por "los bienes y servicios que forman parte de los hábitos de consumo, cultura y tradición de los diferentes pueblos y naciones", y son objeto de añoranza de los grupos que emigraron al extranjero, pero difíciles de obtener en sus destinos. Por su parte, los productos étnicos son "aquellos asociados a un país,

\footnotetext{
167 Hispanic Business Inc. (2003)

${ }^{168}$ Véase el artículo titulado "Van Pymes por el nicho hispano en EU", en Milenio, 31 de octubre de 2006.
} 
pero que en el exterior los consumen tanto los nacionales como otros grupos de población". ${ }^{169}$

Los migrantes no consumen en sus destinos los productos que usaban en sus países de origen solamente para reproducir los hábitos de su vida cotidiana, sino para recordar su infancia y la vida de sus terruños y recuperar lo que han dejado en el pasado y en sus países de origen a través del consumo de ciertos productos. En este sentido, la nostalgia es un fundamento del deseo adquisitivo de los consumidores migrantes en ese mercado, al cual los periodistas, analistas e investigadores mexicanos han llamado "mercado de la nostalgia". Pero, hoy en día, en el mercado hispano, los productos de la nostalgia no sólo se consumen por la población hispana, sino también por un segmento creciente de la población no hispana en Estados Unidos como productos no tradicionales o "exóticos".

Juan Manuel Mendoza Guerrero y Arturo Santamaría Gómez cuya investigación sobre "Los emigrantes mexicanos y la creación del mercado hispano en Estados Unidos" obtuvo el primer lugar del "Premio Anual de Investigación del Comercio Internacional 2003", comentan sobre el consumo de la nostalgia de los migrantes mexicanos en el mercado hispano en Estados Unidos. ${ }^{170}$ Sostienen que en el caso de consumidores de origen mexicano en ese país, el deseo de reproducir en un país ajeno costumbres propias ha llevado a los migrantes mexicanos a buscar lo que consumían en sus pueblos de origen, y que el consumo de la nostalgia está estrechamente ligado con su deseo de mantener y reforzar la identidad nacional. Para los migrantes mexicanos que viven en un país ajeno como grupo social minoritario, "consumir cierto tipo de productos como tortillas, tequila, mole, chile, cerveza, o escuchar música norteña o grupera, representa un acto de identificación y ratificación cultural" y "una forma de ser mexicanos".

En los años recientes, esta magnitud del "mercado de la nostalgia" ha despertado un fuerte interés de parte de diversas instancias públicas y privadas en el país de origen de los migrantes mexicanos. Desde la segunda mitad de los años

\footnotetext{
${ }^{169}$ Cruz e. al. $(2004: 8,9)$.

170 Hernández G. (2003).
} 
noventa, se ha organizado anualmente un foro de negocios por la Fundación Solidaridad Mexicano-Americano y la Secretaría de Relaciones Exteriores de México. El motivo de la organización de este evento fue el siguiente: Aunque este mercado de consumidores mexicanos en Estados Unidos tiene capacidad potencial de expansión, se ha visto una mayor necesidad de encontrar proveedores en México. De este contexto surgió la idea de organizar un foro para difundir la información del mercado y tener encuentros con los empresarios pequeños y medianos. La Promoción Económica Internacional de la Secretaría de Relaciones Exteriores, la Secretaría de Economía, el Banco Nacional de Comercio Exterior y la Fundación Solidaridad Mexicano-Americana formaron un grupo que se llama el Consejo de Promoción de Negocios con las Comunidades Hispanas de Estados Unidos. Dentro del Consejo también están la Cámara Nacional de la Industria de la Transformación, la Cámara de la Ciudad de México, el Consejo Mexicano de Comercio Exterior, la Asociación Nacional de Importadores y Exportadores de la República Mexicana. La principal actividad del consejo es la organización anual del "Foro de Negocios Acercamiento al Mercado Hispano de Estados Unidos y Canadá" que comenzó a finales de los años noventa. Aunque algunas grandes empresas mexicanas patrocinan el evento, las empresas pequeñas y medianas son principales participantes del foro. El objetivo fundamental del foro es crear un esquema de acercamiento de empresas pequeñas y medianas mexicanas con empresas pequeñas y medianas hispanas y buscar estrategias de penetración de productos mexicanos al mercado hispano de Estados Unidos.

Algunos estudios señalan que el mercado de consumidores hispanos en Estados Unidos le ofrece a una gran diversidad de productores de los países emisores de migrantes, principalmente, las micro, pequeñas y medianas empresas que se han visto rezagadas en sus países, oportunidades para buscar crecimiento y expansión de negocio a través de la introducción de sus productos y servicios en el mercado hispano. ${ }^{171}$ Hay varios beneficios que pueden recibir los países emisores a través de la inserción de productos nacionales en este mercado, tales

${ }^{171}$ Cruz et al. (2004). 
como, la generación de incentivos para la producción y la exportación de mercancías y servicios que permitan generar más empleos, para la recuperación e innovación de productos tradicionales, la promoción de conservación de las costumbres y tradiciones nacionales, estatales, municipales y regionales. ${ }^{172}$

Por su parte, Richard Mines y Sandra Nichols (2005) sostienen que la existencia de un gran mercado de la nostalgia en Estados Unidos para productos mexicanos no es un factor suficiente por sí solo para promover el desarrollo económico de lugares de origen de los migrantes. Para referirse al mercado de la nostalgia de consumidores mexicanos de Estados Unidos, ellos utilizan el término "mercado paisano". Pero estos investigadores no ven el mercado de consumidores hispanos en Estados Unidos como único terreno de consumo de los productos de la nostalgia. En su investigación, las localidades de origen de los migrantes también están incluidas como otros puntos del mercado de la nostalgia, dado que los migrantes consumen los productos típicos locales y regionales al visitar sus terruños. Si se amplia el terreno analítico de este modo, se puede observar que hay diferentes barreras y oportunidades entre los pequeños y medianos productores mexicanos dependiendo de la categoría de productos de la nostalgia y del equipamiento, el recurso económico, la infraestructura y el apoyo con los que pueden contar.

En suma, en el proceso de crecimiento y expansión del mercado de la nostalgia tanto en Estados Unidos como en las localidades de origen de los migrantes, los migrantes mexicanos no se deben de entender simplemente como una masa poblacional de mano de obra barata. Más bien, han sido vistos como consumidores potenciales en el mercado y se han convertido en el blanco de la mercadotecnia de las corporaciones y las instituciones gubernamentales tanto en el contexto nacional como en el terreno transnacional.

En este capítulo, intento describir el mercado de la nostalgia de manera etnográfica, a través de los casos concretos de los jalostotitlenses que se han insertado en este mercado de expansión como comerciantes, sobre todo, aquellos comerciantes que venden productos y servicios ligados a la nostalgia tanto en sus

172 Olmedo Carranza (2006). 
lugares de destino en California como en su localidad de origen, con el fin de entender el mecanismo y las características de este mercado de la nostalgia.

El primer énfasis de análisis radica en la relación entre el mercado de consumidores migrantes y el espacio de vida de los migrantes construido en torno a la migración transnacional. Para entender los papeles que juega este mercado en la vida de los migrantes y las influencias que dan las experiencias de los sujetos de vivir dentro de las conexiones transnacionales sobre el mercado, no pretendo manejar el mercado y el espacio de vida de los migrantes como dos terrenos separados. Más bien, algunos aspectos de la vida de los jalostotitlenses dentro de las conexiones transnacionales están entretejidos en el mercado de la nostalgia. Por lo tanto, mi intención en este capítulo es enfocarme en los puntos de entrecruce entre la dimensión emocional, la simbólica y la económica de la vida de los migrantes, es decir, entre el sentimiento que surge de las experiencias migratoria, las prácticas simbólicas de los jalostotitlenses y sus actividades económicas.

Para ello, pongo el segundo énfasis de análisis en la relación entre la nostalgia, el consumo cultural y la identidad. Lo que demuestran los casos que presentaré en las siguientes páginas es que la nostalgia y los signos de terruño juegan elementos fundamentales en la mercadotecnia de los comerciantes jalostotitlenses dentro del "mercado de la nostalgia" o "mercado paisano". Estos actores han hecho esfuerzos en el detallado manejo simbólico de la presentación y la promoción de mercancías y servicios para convertir sus productos en los signos que crean un vínculo simbólico y emocional con los terruños y el país de origen de los migrantes mexicanos, lo cual ha sido el factor fundamental para atraer a los consumidores migrantes que experimentan la nostalgia hacia la identidad local, étnica o nacional y desean encontrarse en sus propios espacios de pertenencia.

\section{SUPERMERCADO DE LA NOSTALGIA}

Muchos de mis informantes, quienes ya llevaban varias décadas viviendo en el sur de California, me comentaron que cuando comenzaron sus vidas migratorias 
en los años cincuenta y los años sesenta, era difícil preparar comida mexicana en casa, dado que no había tantas tiendas que manejaban alimentos mexicanos alrededor de sus casas como hoy en día. En sus localidades asentadas, había algunas tiendas que vendían alimentos básicos para la gastronomía mexicana, tales como, chiles y tortillas, pero no tenían variedad de alimentos. Lo que hacían entonces para conseguirlos era ir al Downtown de Los Ángeles o Huntington Park donde había tiendas pequeñas de productos mexicanos. También iban a Tijuana para comprar los mandados de sus esposas o de algunos paisanos que no tenían papeles y para comer comida mexicana.

Hoy en día, es fácil conseguir una gran variedad de alimentos mexicanos en las tiendas y supermercados cercanos de sus casas y disfrutar de la comida mexicana en general y la comida regional en varios restaurantes en las localidades asentados en el sur de California. La proliferación de sitios de consumo de alimentos y la comida mexicana en los asentamientos le ha permitido a los migrantes jalostotitlenses mantener la costumbre gastronómica de su lugar de origen en Estados Unidos.

Pero la comida mexicana no sólo ha sido integrada a la vida cotidiana de las familias migrantes jalostotitlenses como principal platillo del hogar, sino como un elemento indispensable para ocasiones de fiestas familiares y eventos sociales y religiosos entre los paisanos. Los platillos mexicanos, tales como, carnitas, pozole, enchiladas, son lo que preparan los jalostotitlenses para acompañar la celebración de cumpleaños de algún familiar o de las fiestas de la Virgen de la Asunción en California.

Buckser (1999), quien estudia la relación entre el acto culinario y la identidad entre los judíos en Dinamarca, sostiene que la comida se ha vuelto en uno de los medios simbólicos más importantes para expresar ideas sobre la identidad tanto para individuos como para grupos sociales y étnicos. En el caso de los migrantes jalostotitlenses en Estados Unidos, el sabor de la comida mexicana ha sido un fuerte signo que evoca recuerdos del pasado y la imagen del terruño y crea un vínculo simbólico y emocional con el terruño, y el acto culinario étnico es un medio para reafirmar y reforzar la identidad social a través del consumo de los signos de 
terruño. La experiencia de distanciarse con el hogar de México y de haberse separado del sabor de la comida del país de origen en aquella época difícil de conseguir comida mexicana en el destino, han convertido los alimentos mexicanos en signos de terruño y en objetos cargados de valor simbólico y sentimental para los migrantes. De alguna manera, consumiendo estos signos, llenan su hambriento deseo de mantener presente su terruño en la memoria y en su espacio de vida en un país ajeno.

Northgate González Market es uno de los supermercados que han sostenido la costumbre gastronómica arraigada en el país de origen tanto para muchas familias originarias de Jalostotitlán como para un gran número de otros migrantes mexicanos. ${ }^{173}$

Como la mayoría de los jalostotitlenses, don Miguel González Jiménez nació en un rancho de Jalostotitlán a principios de los años veinte. Ahí pasó su infancia. Aunque su familia tenía el rancho, él comenzó un negocio de zapatería en el centro de Jalostotitlán. En 1952 el negocio de zapatería de don Miguel se quemó por un incendio. A pesar de haber hecho esfuerzos para levantar su negocio de nuevo, era difícil mantener a su familia. Esta fue la razón por la cual decidió ir con sus dos hijos mayores a Estados Unidos en 1966, dejando a su esposa y el resto de sus hijos en Jalostotitlán. Gracias al apoyo de un familiar que ya estaba en California, consiguieron trabajo en el Hotel Biltmore de Los Ángeles, donde varios de sus paisanos de Jalostotitlán trabajaban. Después de tantos años de separación, su esposa y otros hijos consiguieron papeles y lograron vivir juntos en California a finales de los años setenta.

La idea de abrir un negocio propio surgió de su hijo Miguel González Reynoso, quien trabajaba con él en una fábrica de cables. Miguel "chico" llegó a

${ }^{173}$ La historia de la familia González se basa en El libro de los talentos escrito por Jáuregui Pérez (1981: 26’30), el artículo del periódico escrito por Valeria Godines, "Market Mogul launched dynasty: The late patriarch of the Gonzalez chain was better known in Mexico than in O.C.", The Orange County Register, Aug. 17, 2003., y la entrevista que realicé en noviembre de 2004 en el condado de Orange. La venta de alimentos mexicanos es uno de los sectores comerciales en los cuales algunas empresas de los migrantes originarios de Jalostotitlán han tenido un éxito. En este sector, además de Northgate González Market, en California hay otros supermercados cuyos propietarios son jalostotitlenses, como Vallarta Supermarkets que tiene 24 sucursales en los condados de Los Ángeles, Ventura, San Bernardino, Kernn y Fresno. 
California en 1968 cuando tenía 18 años. Mientras trabajaba en la fábrica, inició sus experiencias comerciales. Puso una zapatería en Norwalk, el condado de Los Ángeles, vendiendo calzados de Guadalajara, de León y de Jalostotitlán en pequeñas cantidades. Pero se dio cuenta de que sería mejor abrir un negocio de abarrotes para buscar una mayor venta. Al principio, a sus padres no les gustó la idea de abrir un negocio, dado que ya habían perdido uno por un incendio en su tierra natal. Pero, finalmente la entusiasta insistencia de Miguel "chico" convenció a su padre.

En los años setenta, no había tantas tiendas que manejaban productos mexicanos en las localidades asentadas por los migrantes mexicanos en los suburbios del sur de California. Tenían que ir en coche a Huntington Park u otros lugares donde había tiendas pequeñas de productos mexicanos. Por eso, se vio la necesidad de sitios de consumo de alimentos mexicanos cercanos a sus domicilios. Don Miguel y su hijo sabían que en Anaheim había muchos mexicanos y pocas tiendas pequeñas que vendieran productos mexicanos. Por eso, pensaron que sería buena oportunidad comenzar con un negocio de abarrotes en Anaheim. Además, podrían crear una fuente de trabajo para que toda la familia pudiera trabajar junta en el mismo lugar.

Un paisano de Jalostotitlán, quien trabajaba como corredor profesional de bienes inmuebles en Estados Unidos les recomendó comprar una tienda ubicada sobre el boulevard Anaheim en la ciudad del mismo nombre. La compra de este local fue posible por la venta de la casa de Miguel "chico" y el financiamiento que consiguieron por la hipoteca de la casa de su padre porque subió el precio de las casas que habían comprado debido a la urbanización de suburbios del sur de California. En enero de 1980, se abrió el primer establecimiento comercial de Northgate González Market. La tienda que ellos compraron se llamaba Northgate porque estaba ubicada en la antigua entrada del norte de Anaheim. Era una tienda conocida por la gente de la zona, por eso, ellos pusieron a ese nombre original el apellido de la familia. La primera tienda Northgate González Market era una tienda donde se vendían abarrotes, carne y un poco de ropa y calzado. Ahí trabajaban el padre y la mayoría de sus hijos. La tienda atraía a muchos clientes y les vendían 
tantos productos que pronto se abrieron otras sucursales en el condado de Orange. Aunque el negocio estaba creciendo rápidamente, Miguel "chico" no quiso frenar la expansión hasta que cada uno de sus hermanos y hermanas tuviera su propia tienda. A lo largo de dos décadas, el negocio de la familia González se convirtió en una cadena de supermercados que domina el mercado hispano del condado de Orange y se extiende en varias localidades del condado de Orange y el condado de Los Ángeles. En el año 2003, la empresa contaba con 13 locales, tenía cerca de 2000 empleados y ganaba anualmente 286 millones de dólares en venta. Aunque ya había cumplido el objetivo de tener 13 tiendas, Northgate González Market siguió creciendo. Cuando yo estaba en el condado de Orange en el otoño de 2004, había 17 tiendas: cuatro tiendas en Anaheim; seis en Santa Ana; una sucursal en cada una de las siguientes localidades: Bell, Buena Park, La Habra, La Puente, Long Beach, Pico Rivera y Paramount. ${ }^{174}$

Uno de los factores importantes que han contribuido a la expansión de Northgate González Market es el crecimiento demográfico de la población hispana en el condado de Orange. Por ejemplo, Anaheim, la ciudad en donde se abrió el primer establecimiento comercial y actualmente tiene cuatro tiendas, tenía 166,701 habitantes en 1970. Pero, 30 años después, la población total se duplicó y la ciudad llegó a tener 328,014 habitantes en 2000. El 46.8 por ciento de esta población era de origen hispano. ${ }^{175}$ Cabe destacar que este incremento demográfico de la población hispana sostenido por la migración, principalmente desde México, no significa un simple aumento de trabajadores y habitantes hispanos, sino el crecimiento de personas con gran capacidad adquisitiva. Entre 1975 y 1990 creció el poder de compra de la población hispana en Estados Unidos. Se estima que su poder de compra alcanzaba los 207.5 mil millones de dólares en 1990 a nivel nacional (Humphreys, 2000: 14). Pero en 2001, aumentó más del doble y alcanzaba los 452.4 mi millones dólares (Hayes-Bautista, 2004: 91).

174 Posteriormente la cadena de este supermercado ha demostrado más expansión. Actualmente esta cadena de supermercados cuenta con 23 sucursales y más de 3,500 empleados. Pronto abrirá otra nueva sucursal.

${ }^{175}$ April Decennial of Population, U.S. Census Bureau (2000). 
En los años ochenta, la década en que se instaló la primera tienda Northgate González Market, no había suficientes negocios que atendían a la creciente población mexicana en el condado de Orange. Las experiencias de haber vivido en este proceso de crecimiento demográfico de la población hispana y de haber iniciado con un pequeño comercio de calzados en Estados Unidos les permitieron a los González leer el contexto social adecuado para iniciar con el negocio de abarrotes. Para captar el momento justo y la ubicación justa para abrir nuevas sucursales, actualmente la empresa hace una investigación previa sobre la composición demográfica de cada área en donde planean establecer una nueva tienda. En este sentido, no es sorprendente que existan más tiendas en Santa Ana, la ciudad que ha demostrado un enorme crecimiento de la población hispana. ${ }^{176}$

Otro factor importante para su expansión es captar la preferencia de los consumidores hispanos. Cada supermercado está diseñado como una mezcla de supermercado y mercado tradicional de provincia de México: la sección de frutas y verduras frescas donde se pueden encontrar una gran variedad de chiles, aguacates, otras verduras necesarias para la cocina mexicana; la sección amplia de la carnicería donde varios carniceros atienden a los clientes; la sección de comida mexicana preparada; la sección de pescados y mariscos; la tortillería; varios estantes de alimentos procesados, de bebidas, y de artículos de necesidad cotidiana; la sección de productos lácteos donde se pueden encontrar quesos de diferentes tipos y cremas mexicanas, centroamericana y salvadoreña. En las tiendas, los clientes pueden encontrar alimentos y otros artículos para preparar la comida mexicana en general y platillos centroamericanos en particular. El abastecimiento de alimentos frescos, tales como, carnes, verduras, frutas, es un aspecto importante para atraer a los consumidores hispanos. Según el dato que presenta David E. Hayes-Bautista en su libro (2004: 91, 92), en comparación con el patrón de consumo de la población no hispana, los consumidores hispanos compran alimentos frescos con preferencia (entre 42 y 50 por ciento más alto de lo que consume la población no hispana), en cambio, consumen menos los

${ }^{176}$ La población hispana de Santa Ana ocupaba $76.1 \%$ de la población total 2000 (U.S. Census Bereau, 2000). 
productos procesados y congelados que la población no hispana en Estados Unidos.

Otro aspecto atractivo de Northgate González Market es que los clientes pueden usar español para encontrar los productos que buscan, preguntar y pedir algo al personal y pagar en la caja. En estas tiendas, los hispanos no tienen que estar callados o nerviosos ni preocuparse de cómo encontrar lo que quieren comprar y cómo pedir al personal en inglés.

De alguna manera, el ambiente del supermercado les permite a los clientes tener una experiencia de simulacro de estar en México o en algún mercado de la provincia de México porque los productos, el idioma español, la decoración del interior de la tienda, los empleados y clientes de origen mexicano son signos que evocan la imagen de México y crean un ambiente diferente de algunos espacios socioculturales de la vida cotidiana, donde son vistos y tratados como una minoría étnica en ese país. En el supermercado, no tienen que sentirse como sujetos ajenos ni extranjeros, pueden hablar español y encontrar los productos para recordar sus terruños y para mantener las costumbres gastronómicas de sus regiones y sentir que están en su "casa".

En la entrevista realizada en la tienda en La Habra, don Miguel González Reynoso (Miguel "chico"), me explicó que el ambiente de las tiendas y el patrón del consumo están vinculados con la vida que llevaban los clientes mexicanos en sus lugares de origen en la provincia de México

nosotros tratamos de hacer el mercado de "nosotros" y de crear una atmósfera que los clientes sientan que están en su tierra y están en su lugar...Ir a la compra los domingos a la tienda es como una tradición para ellos. Yo creo que eso viene desde allá. Yo recuerdo, cuando estaba chico, que entonces mucha gente que vivía en ranchos subía de compras (al pueblo). Su forma de ser es la misma que aquí. Se venían de ranchos el domingo, iban a la misa y de misa iban a comprar lo que necesitaban [...] yo creo que aquí hay muchas personas (que son) hijos de gente que trabajó en ranchos. ${ }^{177}$

También me explicó que muchas personas venían a las tiendas en los días entre semana en diferentes horarios dependiendo del horario de sus trabajos, y que había clientes que visitaban diario las tiendas para comprar la carne fresca para el

${ }^{177}$ Entrevista realizada en La Habra, California, el 11 de noviembre de 2004. 
consumo del día, dado que en la provincia de México, como Jalostotitlán, la gente no compraba una vez una gran cantidad de carne para consumir durante dos o tres días, sino la cantidad suficiente para el consumo del día.

Por eso, la presentación del ambiente sociocultural familiar a los consumidores hispanos, principalmente a los de origen mexicano, tiene un peso mayor en las estrategias de mercadotecnia de la empresa. El simbolismo que crea el ambiente del hogar y del terruño para los clientes mexicanos se observa en la decoración de la tienda y las frases publicitarias. Por ejemplo, en la entrada de la tienda en La Habra hay un dibujo de un charro montado a caballo en un paisaje rural compuesto de cielo, montaña y la torre de una iglesia. En la camioneta de supermercado está pintada la siguiente frase: "Feliz retorno a casa". En el papel para empaquetar la carne: "Garantía de calidad. Northgate Supermarket. El Mercado del Pueblo!"

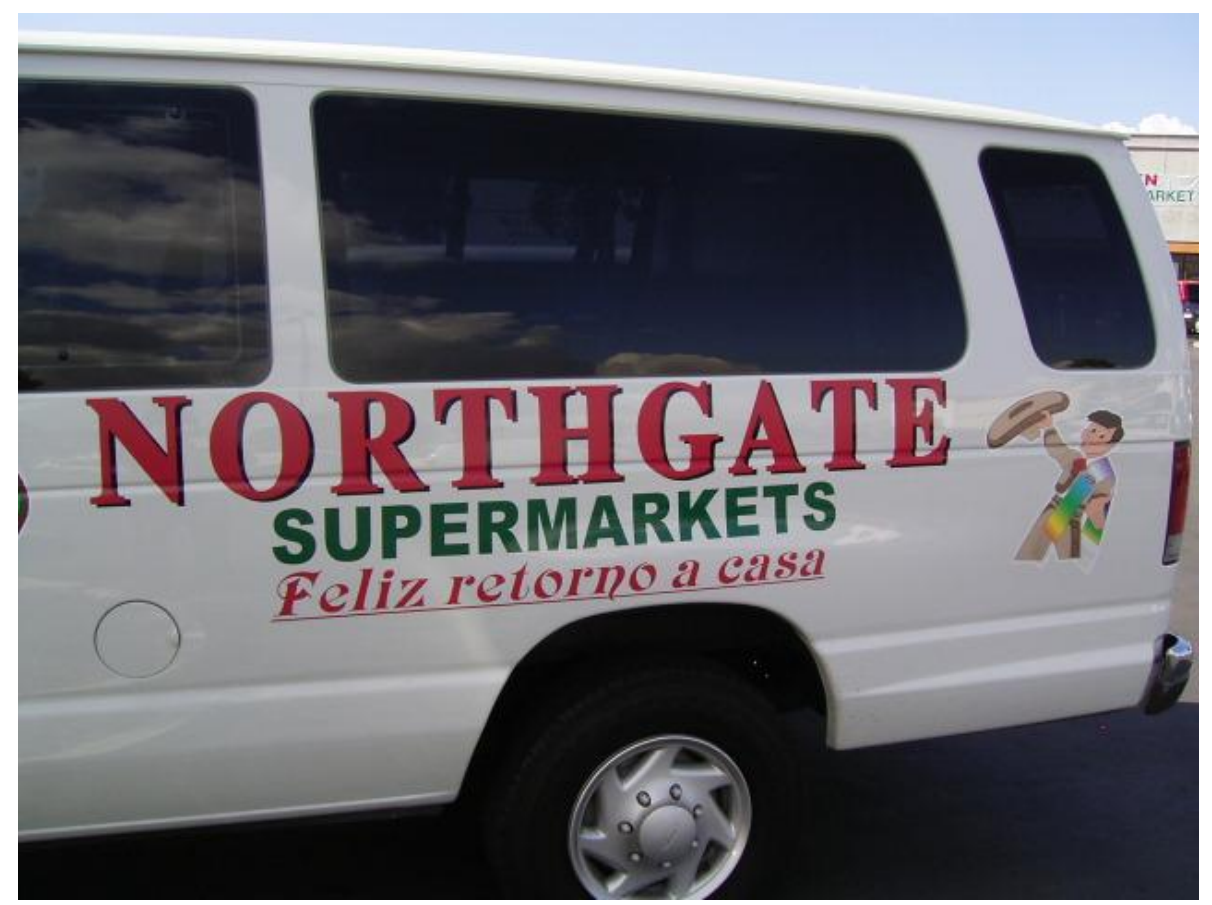

La camioneta de Northgate González Market

Los supermercados también cuentan con algunos servicios necesarios para los consumidores migrantes. Por ejemplo, el cambio de cheque es un servicio atractivo para los migrantes que tienen dificultad de abrir una cuenta bancaria en Estados Unidos. Los migrantes jalostotitlenses que compraban los productos en 
los supermercados Northgate González Market me comentaron que en vez de cobrar comisión al cambiar a efectivo el cheque que les dieron en el trabajo, las tiendas les daban cupones por alguna cantidad de dinero que sólo podían usarse para la compra de productos en las tiendas y el dinero en efectivo de la cantidad de la cual está deducido el precio de los cupones o no cobraban nada si los clientes gastaba más de 20 dólares en compra de productos de la tienda. Los supermercados también les ofrecen a los clientes los servicios necesarios para hacer contacto con sus lugares de origen, tales como, servicio de envío de dinero y venta de tarjetas de teléfono para llamadas internacionales.

En suma, los supermercados Northgate González Market les permiten a sus clientes estar "cerca de casa" en varias maneras: Los productos, la decoración de la tienda, el español y los empleados y clientes de origen mexicano son signos que crean el ambiente de terruño que les hacen sentir estar en casa y les permiten regresar a sus terruños de México de manera simbólica; las tiendas tienen servicios y productos para hacer contacto con sus familias y otros seres queridos de sus lugares de origen a través del envío de dinero y las llamadas telefónicas; por último, la ubicación de las tiendas en las áreas concentradas de la población hispana les permiten regresar a "casa" de manera simbólica con facilidad en su vida cotidiana, dado que los "mercados de pueblo" se encuentran cerca de sus domicilios en suburbios mexicanos del sur de California.

Cabe señalar que la expansión de la cadena de supermercados Northgate González Market ha dado múltiples beneficios para los jalostotitlenses tanto en California como en la localidad de su origen. La empresa no sólo ha creado sitios de consumo de productos mexicanos en el país receptor para los migrantes jalostotitlenses, sino una importante fuente de empleo en el condado de Orange. Cerca de 200 personas originarias de Jalostotitlán trabajan en la oficina de la empresa, las tiendas y la bodega de supermercados. Para algunos migrantes jóvenes recién llegados a Estados Unidos, el trabajo con Northgate González Market fue una de sus primeras labores migratorias en Estados Unidos. En este sentido, se podría decir que la empresa es una "puerta del Norte" de los migrantes jóvenes para iniciar sus carreras migratorias. También hay jalostotitlenses que 
trabajan de medio tiempo en alguna sucursal y se dedican a otro trabajo el resto del día. Por tanto, para los migrantes jalostotitlenses, los supermercados han servido como puntos de reencuentro con los paisanos en el condado de Orange. Otro beneficio importante que la empresa ha dado a sus paisanos de California es su participación como patrocinador de la celebración de las fiestas religiosas dedicadas a la Virgen de la Asunción en el sur de California. Aparte de dar beneficios a los jalostotitlenses, la empresa ha participado en las actividades no lucrativas para la comunidad hispana en Estados Unidos para promover el reconocimiento de la presencia y la participación de los hispanos en la sociedad estadounidense y para apoyar la educación dando becas a los estudiantes.

Jalostotitlán y sus habitantes también han recibido un gran beneficio del éxito económico de la empresa. La familia González hizo generosas donaciones cuando la iglesia local necesitaba recursos económicos para la remodelación de sitios sagrados de la cabecera municipal y para la construcción del nuevo templo dedicado al padre Toribio Romo. Sus apoyos también contribuyeron a la construcción del nuevo campo empastado de fútbol, llamado "unidad deportiva Miguel González", en donde se encuentra un monumento dedicado al honor de don Miguel González Jiménez que apoyaba el deporte de Jalostotitlán. Actualmente la empresa patrocina a un atleta originario de Jalostotitlán para apoyar su participación en campeonatos de maratón en Estados Unidos. También tiene un equipo de charreadas que participa en torneos organizados en Estados Unidos, en el torneo de México y en el carnaval de Jalostotitlán.

A pesar de haber vivido y haber expandido su negocio en las áreas urbanas del condado de Orange y de haber realizado el sueño americano exitoso, don Miguel González Jiménez tenía una profunda añoranza por la vida rural y su tierra natal. Pasaba su tiempo de descanso en el rancho que compró la familia en el condado de Riverside. Regresaba a Jalostotitlán para las fiestas locales. En 1993, cumplió su sueño de vida, recuperando una parte de terreno del rancho de su familia donde él nació y creció en Jalostotitlán. En agosto de 1999, mientras estaba en Jalostotitlán para celebrar las fiestas patronales de la Virgen de la Asunción, su salud se complicó. Falleció el 17 de agosto, el día en que su familia 
organizaba una convivencia en el rancho como otras familias jalostotitlenses. Visitaban a su familia para expresar la condolencia un gran número de habitantes de Jalostotiltlán que recibieron en momentos difíciles de la vida los apoyos económicos de parte de don Miguel. Su cuerpo fue enterrado en Jalostotitlán, la tierra que añoraba tanto durante su vida migratoria. Era el padre de 13 hijos y el abuelo de 51 nietos. A pesar de su muerte, su vida está presente en el paisaje de Jalostotitlán y en los recuerdos de los habitantes y los migrantes jalostotitlenses. Los jalostotitlenses aprecian la sencillez de la vida que llevaba don Miguel, el amor por la familia y por la patria chica, su fuerte arraigo a la vida rural tradicional, su devoción religiosa y su generosidad para apoyar a su tierra natal. Hoy en día, la gente de Jalostotitlán cuenta los recuerdos de su vida como una anécdota de vida ejemplar de un migrante jalostotitlense.

\section{CONSUMO DE LA NOSTALGIA DE LOS JÓVENES}

Durante el trabajo de campo en Jalostotitlán, algunos jóvenes que tuvieron experiencias migratorias en el sur de California me comentaron que en Anaheim vivía mucha gente de Jalos y había varios negocios de personas originarias de Jalos, e incluso había una discoteca llamada "Xalos bar", donde trabajaban y adonde iban a bailar los jóvenes de Jalostotitlán. Durante mi estancia en el condado de Orange, Xalos bar fue una de las imágenes de terruño que decidí seguir en el trabajo de campo en California. Uno de los hijos de don Antonio, quien me ofreció hospedaje en su casa de Brea, en el condado de Orange, me enseñó cómo llegar al bar. Él sabía la ubicación del bar porque algunas veces había ido al bar y ahí trabajaban sus amigos de Jalostotitlán.

Sobre Kraemer Blvd. que atraviesa la zona industrial de Anaheim se encontraba un letrero grande que decía "Xalos Restaurant \& Bar Mexican Food Mariscos". El local de un piso que tenía palmas a su alrededor era el bar que yo buscaba. Al entrar a la instalación, me recibieron varias fotos antiguas en blanco y negro con marcos de madera y un cartel, pegados en la pared que estaba frente a la recepción. 38 fotos que había ahí eran de iglesias, calles, plaza de toros, casas y paisaje del campo de Jalostotitlán y un hombre con sombrero y rifle. En el cartel 
titulado "Jalostotitlán, Jalisco", había fotos del templo parroquial, del templo del Sagrado Corazón de Jesús y de la calle del centro de Jalostotitlán y una prosa titulada "Corazón Alteño", que tenía algunas frases que me llamaron la atención:

No hay un pueblo más lindo y más hermoso que en Los Altos [...] Muy bonito es San Miguel el Alto, Teocaltiche, San Juan, y San Julian. Toy seguro que Tepa es muy hermoso. Y que Lagos no se les queda atrás. No lo niego. Pero quiero invitarles que visiten mi Xalostotitlán [...] No lo niego, no lo niego y yo respeto las bellezas que hay nuestro alrededor. No lo niego, no lo niego, no lo niego, pero sé que como Xalos, pues, no hay dos. Es bonita toda la región alteña. No lo niego y orgulloso de ellos estoy. Y me llena de emoción saber que Xalos de los Altos es el mero corazón. ${ }^{178}$

El interior de la instalación era amplio. Había mesas para V.I.P., dos barras, espacio de DJ, una escena, cocina y varias mesas. Posteriormente, me comentó uno de los dueños de este negocio que la instalación tenía capacidad para 400 personas. En el día, de las 10:30 de la mañana a 2:30 de la tarde, el local funcionaba como restaurante, dado que según Antonio García, quien era uno de los socios del negocio en el momento de la entrevista realizada en el otoño de 2004 y quien me atendió para responder a mis preguntas, fuera de este horario no se podían esperar a más clientes debido a la ubicación del local en una zona industrial. Los platillos que se ofrecían en el día eran antojitos mexicanos, tales como, tacos, burritos, tostadas, tacos dorados, chilaquiles, tortas ahogadas y algunos platillos de mariscos.

Antonio García me invitó a desayunar juntos en una mesa que estaba al lado de la cocina. Al sentarme, de repente me saludó un joven que estaba trabajando en la cocina. Me parecía familiar ese joven mexicano, pero no podía recordar quién era. Me dijo que él me había vendido burritos en Jalos. Él era quien vendía burritos en un puesto del centro de Jalostotitlán. Aparte de José de Jesús, el cocinero, dos jóvenes originarios de Jalostotitlán trabajaban en Xalos bar en el día. Antonio García nació en Michoacán, pero de alguna manera ya era parte de la gente de Jalos, dado que se casó con una mujer de Jalostotitlán e iba a Jalos cada año con su esposa, como me dijo él, para renovar su "residencia" en Jalos, o

${ }^{178}$ El cartel titulado "Jalostotitlán, Jalisco", pegado en la pared de la recepción de Xalos bar. 
sea, para renovar lazos con la familia de su esposa. La gente de Jalos también venía a desayunar o almorzar en el local. Por ejemplo, cuando yo estaba almorzando en otros días, conocí a unas personas originarias de Jalostotitlán quienes trabajaban en Northgate González Market y un joven que nació en Estados Unidos pero creció en Jalos. Antonio García me comentó que el ambiente de Xalos bar cambiaba totalmente en la noche de los viernes y sábados cuando funcionaba como discoteca y me recomendó que viniera un fin de semana para conocer más gente de Jalos y de los Altos de Jalisco.

Al llegar al bar alrededor de las diez de la noche del sábado, ya había varios jóvenes de origen hispano que estaban formándose en la entrada. El interior de la instalación estaba medio lleno de jóvenes y se escuchaba una canción de rock en español. A pesar de ser el único asiático en el bar, no me sentía incómodo dado que me acompañó Marco Antonio, otro hijo de don Antonio quien me ofreció hospedaje en su casa, y pude encontrar a otras personas de Jalos: José de Jesús estaba trabajando ahora como "guarura", su hermano en la barra y Juan Manuel Reynoso, un joven migrante originario de Jalostotitlán que es otro socio de Xalos bar, estaba atendiendo a los clientes de las mesas V.I.P. En el patio de la instalación, había un puesto de tacos. Ahí, encontré a un joven que yo había conocido en Jalostotitlán en agosto de 2003. Ahora, ese joven estaba trabajando como taquero con sus padres en el patio de Xalos bar.

En las mesas V.I.P. Juan Manuel me explicó que en esa noche estaban cerca de 350 personas y que en la noche de fines de semana la mayoría de los clientes de la discoteca eran de los Altos de Jalisco y el resto era de otros lugares de México. Me presentó a sus amigos de San Julián y de Tepatitlán, en los Altos de Jalisco. Entre otros jóvenes que estaban en las mesas V.I.P., uno me pareció familiar. Al verme, ese joven me dijo: "¿Te acuerdas de mí? Sacamos fotos en la plaza." Al instante, me acordé que era el niño de entre 12 y 14 años que me preguntó qué era lo que hacía cuando yo estaba observando y sacando fotos de serenatas en la Plaza de Armas de Jalostotitlán en agosto de 2000 cuando comencé el trabajo de campo. Luego, me presentó a sus amigos de su misma edad y saqué una foto de ellos. Desde entonces jamás habíamos vuelto a vernos 
en Jalostotitlán. Ahora ese niño que había conocido en Jalos creció y era más alto que yo.

A pesar de estar en Estados Unidos, lejos de Jalostotilán, iqué pequeño es el mundo! Eso era lo que yo pensaba cuando me fui de Xalos bar. Además del ambiente que se presentaba en el bar con la música en español y con la presencia de un gran número de personas de origen mexicano, el pequeño mundo de gente de Jalos que pude encontrar ahí me emocionó más de lo que esperaba de un bar hispano. Sin embargo, después de la entrevista que hice con Antonio García en días posteriores, me di cuenta de que ese ambiente del "pequeño mundo" que yo experimenté en esa noche de sábado no era simplemente producto de la suerte 0 una coincidencia, sino que de alguna manera era también parte de la mercadotecnia de los dueños y del promotor de este negocio.

Antonio García me explicó que él y Juan Manuel abrieron Xalos bar en abril de 2003. La idea de poner un negocio de discoteca surgió de sus propias experiencias de haber vivido en ambos lados de la frontera entre México y Estados Unidos. Según Antonio, muchos jóvenes de origen mexicano, quienes nacieron y crecieron en México y vinieron a Estados Unidos para trabajar o para vivir, quienes nacieron en Estados Unidos pero crecieron en Estados Unidos dentro del ambiente sociocultural fuertemente mexicano, o quienes nacieron en Estados Unidos pero crecieron en lugares de origen de sus padres en México, tienen un gusto particular por la música. Por lo general, prefieren hip hop latino, rock en español, salsa, merengue y cumbias a la música que les gusta a los jóvenes anglosajones de ese país. Antonio mismo era parte de esa generación de hijos de migrantes mexicanos. Nació en Michoacán y sus padres lo trajeron a Estados Unidos cuando tenía un año. Había varios bares y discotecas en Anaheim, pero él no estaba a gusto en la mayoría de esos lugares nocturnos destinados a los clientes jóvenes que escuchaban música pop y rock en inglés. De ahí surgió la idea de abrir un bar para los jóvenes de origen mexicano que querían disfrutar de un ambiente propio y la música de su gusto.

Antonio me explicó que había tres razones por los cuales Xalos bar atraía a un gran número de jóvenes originarios de los Altos de Jalisco. La primera es 
porque muchos de los jóvenes quieren sentir el ambiente de fiestas de los pueblos natales de sus padres en México, donde ellos mismos vivieron una parte de su vida y donde pasaron sus vacaciones yendo a discotecas y bares cuando regresaban a México temporalmente con sus padres. Aunque Jalostotitlán es lo que evoca el nombre de este negocio, los lugares que están alrededor de Jalostotitlán, tales como San Julián, Tepatitlán, tienen un ambiente de celebración de fiestas locales similar al de Jalostotitlán. En muchos lugares de los Altos de Jalisco, las fiestas locales son ocasiones en que los jóvenes van a bares y discotecas para escuchar la música, bailar y tomar bebidas alcohólicas con sus amigos y parejas. Por eso, los jóvenes que crecieron en ese ambiente de fiestas de sus pueblos de origen, se sienten muy a gusto en Xalos bar. De hecho, me explicó Antonio que el momento en que la gente pide más tequila y baila más en la noche de discoteca es cuando se ponen la música ranchera y la de banda.

La segunda razón es porque además de disfrutar del ambiente de sus terruños a través de la música de su gusto, muchos jóvenes de los Altos de Jalisco van a Xalos bar para encontrar a sus paisanos. Como yo mismo experimenté, muchos de los clientes encuentran a sus amigos y personas del mismo pueblo o de la misma región. Por ejemplo, la función de discoteca de noche de viernes y sábado, en Xalos bar, por lo general, se encuentran docenas de clientes originarios de Jalostotitlán. También hay clientes que conocen a las mujeres de la misma región y comienzan el noviazgo, e incluso hay algunas parejas que posteriormente formalizaron su relación para pensar en matrimonio. Cabe recordar que las fiestas locales de Jalostotitlán son ocasiones de (re)encuentro, particularmente para los jóvenes, son ocasiones para encontrar pareja y renovar el noviazgo. De alguna manera, Xalos bar sustituye esta función social de las fiestas del terruño para los jóvenes originarios de los Altos de Jalisco que viven en el condado de Orange.

La tercera razón por la cual se reúne un gran número de jóvenes de los Altos de Jalisco en Xalos bar es la promoción comercial del negocio entre la población originaria de los Altos de Jalisco en el sur de California. Antonio me explicó que a pesar de que llevaba apenas un año y medio desde el comienzo hasta el otoño de 
2004, Xalos bar pudo tener un éxito relativamente rápido debido a la promoción estratégica que había hecho un promotor de origen mexicano que tenía contrato con Xalos bar. En el programa de radio para el público hispano se anunciaba la función de discoteca de Xalos bar y se convocaba a los jóvenes de los Altos de Jalisco. También invitaba al bar al locutor del programa de radio y personas que trabajaban en los canales de televisión, quienes también eran originarios de los Altos de Jalisco. También se creó una página de Internet de Xalos bar para difundir la información de la función de la discoteca y para poner fotos de los clientes. Ese promotor fue quien inventó la siguiente frase como eslogan publicitario de Xalos bar: "Un poco de Jalisco en el corazón de Anaheim".

En suma, en Xalos bar, la nostalgia hacia el terruño juega un papel importante para convocar a un gran numero de clientes de origen mexicano en un sitio de Anaheim. La nostalgia hacia el ambiente de sitios de entretenimiento de las fiestas de sus lugares de origen, el deseo de tener un espacio propio donde pueden disfrutar del ambiente familiar y de la música de su gusto en un país ajeno y el deseo de estar con su gente que comparte el mismo gusto y el mismo estilo de vida que se han formado en sus experiencias de haber vivido una parte de su vida en México, son las subjetividades que sostienen el consumo de ese sitio nocturno de entretenimiento en una ciudad altamente asentada por la población mexicana. Los anuncios publicitarios, las fotos antiguas de Jalostotitlán, el nombre del bar, los trabajadores y los clientes originarios de los Altos de Jalisco, las melodías y el español que se escuchan en la noche del viernes y sábado y el sabor de la comida mexicana que se sirve en el día son signos que crean el ambiente del terruño y símbolos que les estimulan a los clientes su deseo de consumo de la nostalgia.

\section{COMERCIALIZACIÓN DE FIESTAS LOCALES}

Hasta aquí he presentado dos casos de actividades comerciales de los jalostotitlenses dentro del mercado mexicano de la nostalgia que ha crecido en el proceso de migración mexicana a Estados Unidos y del incremento de la población de origen mexicano en Estados Unidos. Sin embargo, la migración de 
ida no es el único desplazamiento poblacional que ha creado el mercado de la nostalgia y ha convertido a los migrantes mexicanos en consumidores, sino que la migración de retorno también ha creado otros puntos del mercado de la nostalgia en el lado sur de la frontera. Una de las categorías de productos de la nostalgia que Mines y Nochols (2005) analizan para explorar el mercado paisano es productos de localidad específica (locality-specific), es decir, aquellas mercancías elaboradas en las localidades de origen de los migrantes y consumidas por los migrantes originarios de ellas para disfrutar "el sabor de hogar" y para afirmar el sentido de identidad arraigada en sus terruños particulares.

En el caso de Jalostotitlán, como expliqué en el capítulo 3, el surgimiento de vacaciones de familias migrantes en agosto, la facilidad de conseguir el tiempo de ocio para el carnaval entre los migrantes solteros y los jubilados y el mejoramiento en el estatus legal han generado el retorno temporal masivo de los jalostotitlenses que trabajan y radican en Estados Unidos en temporada de fiestas locales en las últimas dos décadas. En este contexto, las fiestas locales se han convertido para las personas que se dedican al sector de comercio y de servicio en momentos oportunos para buscar el mayor ingreso del año. Por ejemplo, las cantinas, bares, discotecas y grupos de banda y mariachis callejeros obtienen la mayor ganancia del año durante las fiestas gracias a los ausentes que desean gozar del "espacio de libertad", es decir, un ambiente liberado de la vida cotidiana sujeta a las estrictas normas sociales, al tiempo de trabajo, a la moderación del consumo y al ahorro en Estados Unidos. Este tipo de servicio también les ofrece la oportunidad para sentir un cambio temporal en el estatus social a través de demostrar a los demás su capacidad de consumo y pasar bien las fiestas con sus novias.

Por su parte, algunos productos típicos regionales se venden más durante las fiestas locales que en otra temporada del año. Una señora que llevaba más de 30 años vendiendo dulces de leche en un puesto fuera del mercado comentó que desde hacía 20 años tenía más clientes que venían de Estados Unidos y que febrero y agosto eran meses en que se vendían más dulces de leche. En su puesto se manejaban los dulces fabricados en otros lugares de México y dulces elaborados a mano en su casa. Su familia se ha dedicado a este negocio de 
fabricación de dulces de leche y su venta desde la generación de su abuelo. Pero este negocio familiar de productos típicos dedicado a la venta de manera local ha podido ampliar su clientela gracias a la llegada masiva de los ausentes durante las fiestas patronales de agosto y el carnaval.

Las fiestas locales también son temporada alta en el sector de servicio. En la cabecera municipal existen tres hoteles, en dos de los cuales la tarifa de habitación triplica en temporada de fiestas para buscar la mayor ganancia del año. Jalostotitlán cuenta con cinco agencias de viaje. Por ejemplo, "Viajes Katty" es una agencia que se abrió en 1996. Vende boletos de avión entre Guadalajara y distintos puntos de Estados Unidos y de vuelos a lugares turísticos de México y organiza tours en camión a Puerto Vallarta, uno de los destinos favoritos de los clientes locales y los que vienen de Estados Unidos. En agosto de 2004, la agencia contrató 15 camiones con destino a Puerto Vallarta, cada uno de los cuales tiene la capacidad de 40 pasajeros. Los meses en que la agencia tiene más visitas de clientes son febrero, agosto y diciembre. En el centro de la cabecera municipal, también existen varias casas de cambio para ofrecer a los visitantes que traen monedas extranjeras, principalmente dólar estadounidense, la facilidad de conseguir pesos mexicanos en Jalostotitlán durante las fiestas locales. Los restaurantes y puestos que venden comida mexicana, tales como birria, menudo, carnitas, pozole, tacos, tortas ahogadas, también tienen más clientes en temporada de fiestas locales gracias a los ausentes que buscan el sabor auténtico del terruño en estos negocios locales.

El retorno temporal masivo de los ausentes en temporada de fiestas locales también ha generado nuevos negocios que manejan mercancías que los ausentes compran con preferencia como artículos de recuerdo de su viaje a Jalos o como regalos para sus familiares y amigos que se quedaron en Estados Unidos. En el centro hay varias tiendas que venden playeras y llaveros con el nombre de Jalostotitlán y con la imagen del templo parroquial y calcomanías de Jalostotitlán.

Durante las fiestas locales, también se venden cintas y discos compactos de colecciones de canciones dedicadas a Jalostotitlán, interpretadas por cantantes 
locales o por grupos musicales locales y regionales. En el disco compacto titulado "Canciones de Mi tierra", está escrito el siguiente mensaje de dedicatoria:

A toda la gente de Jalostotitlán, a los que radican fuera y a los que viven aquí; a sus familiares y amistades y a usted que tiene en sus manos este DISCO QUE CON MUCHO CARIÑO HEMOS HECHO, PARA ACRECENTAR EL ACERVO CULTURAL DE NUESTRO PUEBLO. ${ }^{179}$

En el disco titulado "Voces de Mi Pueblo" que tiene canciones, tales como, “¡Vamos al lienzo Jalos!”, "Bonita mi tierra”, "Jalos”, etc., está escrito el siguiente mensaje de dedicatoria:

Este material está dedicado a todos los Paisanos y Paisanos alrededor del mundo que añoran el momento de volver a sentirse en su pueblo [...] también a las nuevas generaciones que ante la distancia y la diversidad cultural tengan un medio para valorar lo que la tierra y sus raíces les brinda y les extraña cual hijo pródigo. ${ }^{180}$

Lo que se observa en estos productos es que son mercancías cuyos títulos y contenido están diseñados y hechos para provocar la nostalgia y el sentido de pertenencia a Jalostotitlán.

En la plaza hay puestos de artesanías y colecciones de discos compactos de cantantes mexicanos que tenían popularidad en décadas anteriores. Un joven aficionado a la fotografía que trabaja en la relojería en la cabecera municipal tiene un puesto de tarjetas postales que él mismo hace con las fotos antiguas de iglesias y paisaje de Jalostotitlán y las fotos que él mismo sacó. Se dedica a venderlas sólo en el carnaval y las fiestas patronales, dado que muchos ausentes de Estados Unidos compran sus productos como recuerdos de viaje a Jalostotitlán.

Cuando yo estaba grabando con cámara de video las peregrinaciones y otros eventos celebrados durante las fiestas patronales de agosto de 2003, todo el tiempo encontraba a unos camarógrafos que filmaban con atención las escenas de fiestas religiosas. Uno de ellos filmaba con video para un programa de

${ }^{179}$ Disco compacto producido y distribuido por ROMI RECORD en el año 2001. Compré este material en una tienda de artículos de recuerdo con un costo de 90 pesos durante el trabajo de campo realizado entre 2003-2004 en Jalostotitlán.

180 Disco compacto de canciones grabadas en Sino Estudio. Compré este disco compacto en una papelería de Jalostotitlán en el año 2003. 
televisión en el canal local y otros lo hacían para la producción de video o DVD de fiestas locales que se venden en algunas tiendas en las últimas fechas de la festividad. En el carnaval, ellos también graban los eventos, editan la película y posteriormente hacen el video y DVD para la venta. Estos productos se venden a los ausentes como recuerdos de viaje y a los habitantes locales para enviarlos a sus familiares de Estados Unidos que no pudieron asistir a las fiestas locales.

Las fiestas locales son también ocasiones en las que se publican y se presentan los libros sobre Jalostotitlán escritos por los cronistas y escritores jalostotitlenses. Por ejemplo, en agosto de 2000, se organizó en la Casa de la Cultura la presentación del libro titulado Xalostotitlán en imágenes, escrito por Alfredo Gutiérrez R., un arquitecto originario de Jalostotitlán que vive en Guadalajara. En agosto de 2003, hubo la presentación de dos libros: uno es Viaje al corazón de los Altos que se compone de fotografías de Sergio Gutiérrez, un ausente que vive en Estados Unidos, y de las poesías escritas por Atanasio Gutiérrez, quien es originario de Jalostotitlán pero radica en la Ciudad de México; otro es "Jalos" A los ojos de un "Pinolillo" escrito por Apolinar García Aguirre, quien vive en Jalostotitlán. Los ausentes son quienes compran más los libros sobre Jalostotitlán que los habitantes del municipio. La mayoría de ellos no sólo los compran para conocer más de su tierra natal, sino que también los compran y guardan para tenerlos a la mano como símbolos de Jalos. Por eso, tanto las editoriales como los escritores buscan la fecha de publicación y de presentación de libros durante las fiestas locales de agosto para poder promoverlos entre el principal lector.

La razón por la cual los ausentes que vienen de Estados Unidos compran más que los habitantes locales los productos típicos locales y regionales, los libros, cintas y discos compactos de canciones de Jalostotitlán, películas de las fiestas de agosto y del carnaval grabadas en cintas de video y DVD y otros artículos de recuerdo de viaje es que estos productos forman parte de las colecciones personales de los migrantes y sus familias. En el trabajo de campo, al contar sus historias de vida, muchos de mis informantes me enseñaban o hablaban de varios objetos relacionados con Jalostotitlán que guardaban y usaban: la imagen de la 
Virgen de la Asunción, la placa del coche registrado en el Estado de California con el nombre de Jalos, los libros sobre Jalostotitlán, fotos del paisaje de la tierra natal, carteles y folletos de las fiestas patronales y el carnaval, el video y DVD del carnaval, la colección de los sonidos y canciones grabados en el terruño, playeras, cachuchas y calcomanías con el nombre de Jalostotitlán, las páginas de Internet con título de Jalostotitlán donde los autores presentan su perfil personal y la historia y las fiestas de Jalostotitlán.

Ellos no usaban estos objetos solamente por su valor de uso, sino por su valor simbólico. Me los enseñaban para narrar sus recuerdos de Jalostotitlán y algunos acontecimientos de sus historias de vida, sus aficiones que hacían en el tiempo de ocio y su apego al terruño. De alguna manera, el espacio de exhibición de objetos de Jalos era un "mini museo" para recordar su infancia, el estilo de vida que llevaban en su terruño y a los seres queridos que seguían viviendo ahí, para mantener un vínculo simbólico y emocional con su patria chica y para presentar su terruño y representar su identidad arraigada en Jalostotitlán.

Janet Hoskins (1998), quien realizó el trabajo de campo en la comunidad Kodi en Indonesia, confiesa que sus informantes no narraban sus historias de vida y sus identidades como algo que ya está formado esperando que el investigador lo descubra, recolecte y transcriba, sino que narraban las historias de ciertos objetos que ellos valoraban y sus historias de vida de una manera inseparable. Señala que las biografías se forman y se narran alrededor de objetos, y que para ellos los objetos son vehículos para definir sus identidades. Denominan objetos que tiene este papel formador de biografías e identidades como "objetos biográficos".

En el caso de los ausentes de Estados Unidos, los productos que ellos compraron en Jalostotitlán y las fotos de su terruño, películas de las fiestas y páginas de Internet que ellos mismos crearon, son objetos que evocan la imagen de su terruño y se usan para que ellos puedan volver a la tierra natal que dejaron en México y en el pasado, a través de sus memorias y su imaginación. Son símbolos que les ayudan a formar las narrativas de su lugar de origen, su vida y sus identidades. En este sentido, la identidad de ser jalostotitlense no se representa por sí sola ni simplemente por la narrativa, sino a través de la 
presentación de los objetos que el sujeto posee. Hay una anécdota que me contó un jalostotitlense que tuvo 20 años de experiencia migratoria en California, en la cual se refleja el estrecho vínculo entre la identidad local y la práctica de posesión de símbolos del terruño: Cuando él y sus amigos de Jalos conocían a otros mexicanos en California, resultaba que otros también eran de Jalos, dado que todos decían que eran de Jalos con excepción de uno. Le preguntó a uno que estaba callado si también era de Jalos. Le contestó: "No. No soy de Jalos. Jalos es mío".

Víctor Manuel Jiménez, el dueño de una tienda de artículos de recuerdo ubicada en Jalostotitlán, ha entendido muy bien que el deseo adquisitivo de los ausentes está estrechamente ligado con el deseo de reconstrucción y representación de la identidad local a través de los objetos. Antes de comenzar el negocio, Víctor vivía en Guadalajara trabajando en el sector de turismo. Pero no le gustó la vida urbana y decidió regresar a Jalostotitlán. Ahí consiguió la concesión de vender los zapatos de Nike y puso una tienda en 1993. Seis meses después de que comenzó su negocio, un amigo de la infancia inició un negocio de fabricación de playeras y él fue quien le recomendó a Víctor vender playeras en su tienda. Al principio, pensó venderlas como enganches para atraer a más clientes y luego vender más zapatos. Pero, debido a la crisis económica de México, desde el siguiente año bajó mucho la venta de los tenis. En cambio, tuvo éxito en la venta de playeras y ahora resulta que las playeras y otros artículos de recuerdo son lo que se venden más en la tienda.

El éxito de venta de playeras en su tienda tiene que ver con dos factores. Uno es que los ausentes que vienen de Estados Unidos en temporada de fiestas locales son los principales clientes. Ellos buscan los productos que llevan símbolos de Jalostotitlán para regalar a sus parientes y amigos que no pudieron regresar y para representar la identidad local. Incluso, las usan para encontrar a sus paisanos de Jalos o de la región de los Altos en Estados Unidos a través del nombre de Jalostotitlán impreso en las playeras. Él mismo reconoce que lo que vende en la tienda no es un simple producto, sino la nostalgia. El segundo factor es enfocarse en los detalles del diseño de los productos. Si lo que buscan sus 
clientes es la nostalgia, el diseño y los detalles de las playeras son sumamente importantes para que los productos puedan evocar las imágenes del terruño que quieren consumir. Víctor compra las playeras únicamente de su amigo que tiene un taller en otro municipio de los Altos de Jalisco. No quiere usar playeras de baja calidad y fabricadas en otros países aunque pudiera reducir el costo y obtener mayor ganancia, dado que los clientes enfriarían su emoción de tener el símbolo de su terruño al ver el nombre de otro país en la etiqueta. Por ejemplo, anteriormente, en el taller de su amigo se usaban los productos de la marca Hanes para fabricar playeras con diseños pedidos. Pero, al vender las playeras como artículos de recuerdo a los clientes que venían de Estados Unidos, había problema porque se vendían a la gente que venía de Estados Unidos los artículos de recuerdo de México, pero, lo que evocaba la etiqueta de Hanes era otro lugar, es decir, Estados Unidos. Para fabricar playeras de buena calidad y crear su propia marca, su amigo llevó al taller a una persona que había trabajado en la marca Hanes para capacitar a sus trabajadores y nombró una marca propia como "Tlan", que significa lugar en náhuatl. En la etiqueta de la playera puso símbolos de cactus, iguana, nopales y sombrero y "100 \% mexicano".

Víctor mismo diseña las palabras y las imágenes que se imprimen en las playeras que vende en su tienda y en el taller de su amigo se las imprimen en las playeras fabricadas ahí mismo. En la tienda de Víctor hay playeras de distintos diseños: las playeras con la impresión de Jalostotitlán, Jalos, o Xalos, las que tienen la imagen del templo parroquial de Jalostotitlán, la de la Virgen de la Asunción, la de Santo Toribio Romo, otra de Santo Toribio que aparece al lado de un hombre que está subiendo el alambre de la frontera, las playeras con el dibujo de la cabeza de una águila y la impresión que dice "Hecho en Jalos", etc. También tienen playeras con el diseño que mezcla el símbolo local con lo nacional. Por ejemplo, la playera que tiene la impresión de "Jalostotitlán Jalisco México" y una imagen de Pancho Villa con rifle montado en caballo, saliendo del calendario Azteca.

Aparte de las playeras, Víctor vende otro tipo de artículos de recuerdo, tales como, llaveros de Jalos, de la Virgen de la Asunción y de Santo Toribio Romo con 
la imagen de la Virgen de Guadalupe en la parte de atrás, tazas de café con la inscripción de Jalo y un dibujo del templo parroquial, libros sobre la historia local, discos compactos de canciones de Jalostotitlán, botellas artesanales y caballitos para tequila, fotos del templo parroquial, la Plaza de Armas y paisaje de Jalostotitlán, etc. Víctor me explicó que aunque había muchas artesanías y artículos de recuerdo muy económicos fabricados en China, prefería manejar productos mexicanos, dado que no quería que las mercancías que se manejaban en la tienda evocaran la imagen de otra región de México y otro país en que los clientes no podían identificar los símbolos de su terruño. Por ejemplo, las botellas y caballitos para tequila son artesanías de Tonalá, Jalisco, que mandó hacer para el carnaval.

Fuera del trabajo, Víctor se dedica a los estudios históricos de Jalostotitlán. El motivo de empezar a estudiar la historia y las tradiciones locales fue que hace años cuando estaba vendiendo en su tienda un producto que tenía un símbolo prehispánico, un arqueólogo mexicano le dijo que era de los mayas. Le dio mucha pena no conocer bien a su tierra natal. Desde entonces, empezó a leer libros sobre la historia local y regional y a participar en el grupo de estudios históricos de la región de los Altos de Jalisco. Hizo un calendario del año 2001 con las fechas de los acontecimientos históricos del municipio para difundir los conocimientos de la historia de Jalostotitlán y para que la gente supiera que Jalos siempre ha sido un lugar importante en la historia regional y que apreciara más la vida local arraigada en las tradiciones y los valores religiosos. Me comentó que uno no podía negar y borrar su lugar de origen, el lugar de donde vino; si lo niega, era la negación de sí mismo; no podía negar su raíz aunque no le guste su pueblo; la gente que había salido de Jalostotitlán tenía la idea de regresar algún día y siempre tenía la idea de regresar de alguna forma. Por eso, para él, vender las cosas que les recuerdan a los ausentes su lugar de origen, la importancia de las tradiciones, la historia local y la identidad de ser jalostotitlenses es algo que le da gran satisfacción. Sabe que sus mercancías satisfacen la nostalgia de los ausentes y de alguna manera contribuyen a fortalecer vínculos entre la gente que viene de fuera y su tierra natal. En una entrevista que le hice en su tienda, dijo que 
la razón por la cual le da satisfacción su negocio es por el "gusto de cumplir", cumplir con las fiestas, con sus clientes que van y vienen cada año, con su papel de difundir la conciencia de la importancia de la conservación de las tradiciones y fortalecer la identidad de ser jalostotitlenses.

Cabe mencionar que el uso de la nostalgia y de las imágenes del terruño para atraer a los ausentes de Estados Unidos a las fiestas locales no es necesariamente el privilegio del sector comercial de Jalostotitlán. La presidencia municipal es también otro actor importante que participa en la promoción de las fiestas locales de Jalostotitlán entre los migrantes. Para las fiestas de agosto y el carnaval de cada año reparte los folletos de las fiestas, en los cuales se insertan imágenes fotográficas de las candidatas y la ganadora del certamen de la reina de Jalos, las iglesias, corridas de toros, charreadas, serenatas. Estas imágenes, de alguna manera, coinciden con las expectativas de los migrantes de consumir la imagen de lugar sagrado, la de pueblo rural y la de lugar donde pueden encontrar mujeres bellas. Como describí en los capítulos anteriores, estas tres son algunas imágenes dominantes que se reflejan en las narrativas de los migrantes sobre la nostalgia hacia Jalostotitlán.

El carnaval es la festividad local en el cual la presidencia municipal juega el papel de principal organizador junto con los empresarios. En el folleto del carnaval que hizo la presidencia en 2006 aparece el siguiente mensaje del presidente municipal dedicado a los migrantes:

¡Bienvenidos de Nuevo a su Casa!

Nuevamente el Corazón de los Altos de Jalisco, se atavía de gala y se ufana de ser el mejor anfitrión, para dedicarle en esta ocasión la mejor de las fiestas, al MIGRANTE. A aquel que un día con su alforja llena de ilusiones y de esperanzas por mejorar su porvenir, dejó la tierra de la Virgen de la Asunción, de las serenatas dominicales en la plaza y de los dulces de leche; todo para buscar fortuna en donde solo le acompañarán la ausencia y el sueño de volver a vivir, aunque sea por última vez, los venturosos años como la infancia.

El amor a la tierra le obliga a volver, ya que esa tierra fue la que le forjó sus más altas aspiraciones, y aunque nunca las logre, siempre serán su aliciente para continuar en la lucha por llegar a la meta que desde la más temprana edad propuso.

A pesar de la distancia y a pesar del tiempo, Jalostotitlán tiende la mano amiga a sus hijos y en general a todos sus amigos, les recibe con la hospitalidad de siempre, y SOBRAN RAZONES PARA VERNOS EN JALOS. Bien sea porque nos hermana esta tierra de nuestro origen, o bien nos unifica la afición por una buena corrida de toros, 0 
por el gusto de escuchar el tropel de raudos caballos, o por el gusto de valorar un ganado de buena raza, o el deleite de paladear un buen tequila o el ambientarnos escuchando la banda o el mariachi, el placer de apostar en una pelea de gallos, el complacernos apreciando la belleza de las escaramuzas y las faenas de los charros en el más mexicano de los deportes, el admirar la hermosura de las mujeres alteñas, o simplemente el pasar un rato alegre, sano y de convivencia con la familia o los amigos; todo esto y más, es posible disfrutarlo en un mismo lugar, en el Carnaval de Jalos 2006.

Les damos una cálida bienvenida y les deseamos una feliz estancia, esperando que éste periodo de esparcimiento, sea la oportunidad de llenarse de energía positiva para transmitirla a todos sus seres queridos. ${ }^{181}$

En los años recientes el gobierno municipal ha mostrado un mayor interés en los migrantes y en el fenómeno migratorio que en los períodos anteriores. Sin embargo, su acercamiento hacia los migrantes no es solamente para levantar el comercio local aunque el dinero que los ausentes de Estados Unidos gastan durante las fiestas locales es sumamente importante para el comercio local, sino que también se observa el interés político de realizar otros proyectos del gobierno municipal a través de la reincorporación de los migrantes al municipio. En agosto de 2004 organizó una reunión con los migrantes para presentarles los proyectos municipales y presentar la información de 3 por 1. Recientemente se realizó la visita del presidente municipal a Turlock con el fin de buscar la posibilidad de hermanarse en el futuro con la ciudad Turlock en donde los jalostotitlenses han jugado un papel principal en la celebración de la fiesta de la Virgen de la Asunción.

\section{CONCLUSIONES}

Salman Rushdie (1991) y Toni Morison (1990) señalan que el sentido de pérdida del pasado y del hogar es el sentimiento que les hace a escritores diaspóricos reconstruir lo que han perdido por el tiempo y por el desplazamiento físico. Para recuperar el pasado y sus terruños, primero, usan las memorias. Pero las memorias están fragmentadas de manera irreparable. Por eso, usan la imaginación como adhesivo que les permite pegar unas piezas de memorias con otras. Para ellos, escribir las novelas sobre sus terruños y su pasado es un acto de construir sus propios terruños imaginarios y reconstruir sus identidades. En el caso

${ }^{181}$ Mensaje del presidente municipal en el folleto del carnaval de Jalostotitlán, publicado por la presidencia municipal de Jalostotitlán en febrero de 2006. 
de los migrantes mexicanos, Boruchoff (1999) observa que la posesión de las cosas derivadas de otro lado de la frontera son "objetos culturales" que les despiertan a los migrantes recuerdos y la imaginación sobre sus familias y su lugar de origen y crean el vínculo simbólico entre su lugar de destino en Estados Unidos y su lugar de origen en México.

En los casos etnográficos que he descrito en este capítulo, a través del acto de posesión y del consumo de los objetos, los migrantes mantienen sus costumbres y estilos de vida arraigados en México y en sus lugares de origen, hacen presentes sus terruños en la vida cotidiana en Estados Unidos de manera simbólica y reconstruyen las identidades locales, regionales y nacionales, reuniendo en sus manos los signos del terruño para complementar sus recuerdos, nutrir su imaginación y representar sus identidades.

Este deseo de estar cerca de sus terruños aunque sea de manera simbólica y de reconstruir sus identidades y esta práctica de posesión de los símbolos del terruño son la base del deseo adquisitivo de los migrantes y el patrón de consumo que fundamenta el mercado de la nostalgia. Por eso, en la mercadotecnia que hacen los comerciantes jalostotitlenses y en la comercialización de sus productos y servicios, se observa el cuidadoso manejo de símbolos. Decoran las instalaciones comerciales con objetos, sonidos, gente y el idioma que evocan la imagen de México para crear un ambiente de "mercado de pueblo" y de fiestas de su región de origen. Usan frases que les despiertan a los clientes la nostalgia y el deseo de retorno como eslóganes publicitarios. Fabrican y proveen productos que llevan el diseño y los signos en que los clientes pueden "leer" símbolos de su tierra natal. Saben que los signos de terruño son los elementos importantes que convierten los objetos y el servicio en mercancías en las que los clientes identifican el valor simbólico y emocional, aumentan el valor mercantil de objetos y de servicios y marcan la diferencia con otros productos y sitios de competencia.

Lo interesante es que sus conocimientos y visiones comerciales sobre el peso mayor que tienen el sentimiento y los símbolos en el gusto de los clientes y en el patrón de consumo en el mercado de consumidores migrantes de origen mexicano, se han formado a partir del apego a su tierra natal que ellos mismos 
han sentido y a partir de sus propias experiencias de haber vivido una etapa de su vida en Jalostotitlán, como migrantes en Estados Unidos o haber vivido gran parte de su vida en una localidad con una larga historia de migración hacia Estados Unidos.

En este contexto, su imaginación, sus sentimientos y las identidades no son necesariamente algo que surge solamente de su interior. Más bien, las subjetividades son objetos de la mercadotecnia de distintos actores. Para "atrapar" a los consumidores, estos actores usan las redes simbólicas, las "redes" que están hechas de los signos que evocan con la imagen de hogar y de terruño y las frases publicitarias que despiertan la nostalgia. En este sentido, el mercado de la nostalgia no sólo juega el papel de crear oportunidades para iniciar sus propios negocios tanto para los migrantes como para los habitantes de su lugar de origen, sino que también fomenta las actividades comerciales que ha sostenido el acto de poseer los símbolos del terruño y han contribuido a fortalecer el vínculo económico, simbólico y emocional entre los migrantes y Jalostotitlán así como la identidad local entre los migrantes. 


\section{Capítulo 6}

Nostalgia en polémica: ¿Oposición entre los norteños y la población no migrante?

\section{INTRODUCCIÓN}

Hasta aquí hemos visto cómo se han formado diferentes formas de nostalgia entre los ausentes a través de las experiencias de separación espacial y temporal del terruño y cómo sus deseos de estar en el lugar de origen se han utilizado tanto por los ausentes como por los múltiples actores locales de Jalostotitlán para crear y fortalecer vínculos transnacionales y transformar Jalostotitlán y las prácticas socioculturales y económicas en sus lugares de destino en Estados Unidos a través de distintas formas de manejo simbólico de la imagen de terruño. Sin embargo, en el contexto en que se realizan sus sueños de retorno temporal de forma masiva mediante el contacto físico con su lugar de origen y se reconstruye Jalostotitlán para reincorporar a los ausentes a la vida local en cada temporada de fiestas locales, han surgido la nostalgia y las respuestas críticas por parte de algunos sectores locales.

En este capítulo, describiré las polémicas que se han discutido entre los jalostotitlenses en la última década a nivel local acerca de los cambios socioculturales de Jalostotitlán. Los cambios en los cuales me enfocaré aquí se discuten y se interpretan por algunos sectores locales como "problemas sociales" que se han generado como consecuencias del proceso de intensificación del vínculo con otros lugares y otro país por medio de la migración y del retorno temporal masivo de los ausentes radicados en Estados Unidos. Por su parte, la preocupación sobre los cambios socioculturales entendidos de este modo es un factor fundamental del cual ha surgido una forma de representación de identidad local que se define a partir del rechazo y la oposición con los elementos culturales derivados de Estados Unidos. El discurso local que culpa a la migración y a los migrantes por nuevos cambios sociales en la vida local y la manifestación de esta forma de representación de identidad local han provocado a algunos ausentes 
radicados en el sur de California la inconformidad acerca del modo de interpretación de cambios socioculturales en su tierra natal.

Quiero aclarar que es un asunto delicado que alguien externo a la sociedad jalostotitlense, como yo, escriba un tema sobre el cual ha habido discusiones y diferentes versiones en la última década dentro la sociedad estudiada, dado que es muy probable que en el futuro este texto estará fuera del ámbito académico y formará parte de materiales escritos sobre Jalostotitlán que están en manos tanto de sus habitantes como de los ausentes para la lectura, reflexiones, discusiones y críticas. ${ }^{182} \mathrm{Mi}$ intención de escribir este capítulo de la etnografía de Jalostotitlán no es echar leña al fuego de las polémicas tensas entre los migrantes y la población no migrante ni criticar o defender a algún sector de la población estudiada, sino analizar el choque entre diferentes modos de significación de terruño y el contacto entre diferentes modos de interpretación sobre la localidad, la cultura local y la identidad. En mi opinión, este análisis de diferentes formas de nostalgia que están en polémica permite revelar aún más el papel de la nostalgia como una forma de crítica cultural que hace el narrador sobre el presente desde su posicionamiento a través del desplazamiento imaginativo y emocional hacia el terruño imaginario.

En su artículo titulado "Nostalgia-A Polemic" (que me inspiró el título de este capítulo), la antropóloga norteamericana, Kathleen Stewart (1988) sostiene que la nostalgia surge como una práctica cultural importante en la era de "capitalismo tardío" (Mandel, 1978) o "el fin de capitalismo organizado" (Lash \& Urry, 1987). La descentralización y la fragmentación de nuestros espacios de vida y de nuestro presente nos debilitan el sentido del tiempo y lugar y nos hacen experimentar el sentido de pérdida (Jameson, 1984). En este contexto, la nostalgia surge como una práctica cultural que crea un marco para reordenar y "dramatizar" significados de la vida social fragmentada para recuperar nuestro sentido del tiempo y lugar. Pero, como señala Stewart (1988: 228), la forma de nostalgia varía dependiendo

182 Durante el trabajo de campo en Jalostotitlán y en California, prometí a mis informantes hacer la presentación de mi tesis doctoral durante las fiestas de agosto al terminar mis estudios, debido al creciente interés que existe entre los jalostotitlenses en los textos sobre su localidad. Como comenté brevemente en el capítulo anterior y describiré en el siguiente capítulo, en la última década se han publicado varios libros sobre Jalostotitlán escritos por los autores originarios de dicha localidad y se han realizado presentaciones de libros en las fiestas de agosto. 
del posicionamiento en donde se encuentra el sujeto: desde el presente en un lugar, el sujeto construye su propio lugar imaginario como objeto de "su" nostalgia; desde el presente en otro lugar que se expone a las miradas nostálgicas desde el exterior, los "otros", es decir, los habitantes de ese lugar construyen un imaginario sobre su tierra natal que no necesariamente coincide con el imaginario de los viajeros. El paisaje cultural del lugar imaginario no es necesariamente "seductivo" para todos, sino sólo desde el punto de vista del sujeto que construye este imaginario como objeto de su propia nostalgia. Con esta idea, Stewart describe varios casos de la diferencia, la tensión y la contienda entre la nostalgia de clase media y la de clase trabajadora y entre la nostalgia de la cultura de masa y la de los habitantes locales.

Retomando su propuesta de las contiendas entre la nostalgia hegemónica y la de resistencia, planteé en el inicio de mi investigación un esquema de oposición entre la nostalgia de los migrantes y la de los habitantes de Jalostotitlán. Esta perspectiva me permitió recolectar durante el trabajo de campo datos etnográficos sobre las interpretaciones negativas por parte de algunos sectores de la población no migrante de Jalostotitlán respecto al impacto del retorno temporal masivo de los ausentes en temporada de fiestas locales y comparar sus narrativas nostálgicas con las de los migrantes. Como explicaré en los siguientes apartados, en el informe de la presidencia municipal, las revistas locales y los libros publicados en Jalostotitlán se habla de los cambios socioculturales surgidos en el nivel local en las últimas dos décadas y entendidas como "problemas sociales" relacionados con la emigración y la migración del retorno, y en algunos casos, se explican estos "problemas" en una oposición entre los valores tradicionales locales y las influencias de los norteños. ${ }^{183}$ Sin embargo, al analizar las narrativas de críticas locales a los cambios socioculturales y las narrativas de los ausentes, me di cuenta de que el análisis debería de ir más allá de la generalización de la oposición entre los migrantes y la población no migrante.

${ }^{183}$ Como expliqué en el capítulo 4, hay varios términos que se refieren a los migrantes y sus descendientes que viven en Estados Unidos. El término norteño es uno de ellos, pero tiene una connotación negativa, y a veces, se usa para despreciar sus comportamientos diferentes de los de los locales. 


\section{1. "PROBLEMAS SOCIALES" EMERGENTES}

El siguiente artículo titulado "Insistentes Exhortos" encabezó la revista local Expresión de los Altos publicada en el marzo de 2003:

Tema obligado -en los últimos años se ha intensificado- son los reiterativos exhortos para evitar exceso y libertinaje con motivo de la celebración de las fiestas de carnaval en nuestra población, estas los emiten tanto la autoridad eclesiástica como la autoridad civil, sin embargo es una preocupación de los ciudadanos que apelan al orden y a una diversión sana, los que creen poseer valores cristianos que heredan de sus mayores, quienes se preocupan por conservar una buena imagen de esta entrañable tierra.

Estas recomendaciones no se manifiestan en falso, existen diversos fundamentos para emitirlos, de antemano en las diferentes parroquias de la localidad perciben y conocen a fondo la problemática social que de manera desafortunada adolece en nuestro medio (alto índice en consumo de bebidas alcohólicas, drogas y proliferación de la prostitución, esto se ha acentuado por la existencia de tugurios disfrazados) lo cual se recrudece en estas celebraciones profanas.

Nos pronunciamos a favor de participar con entusiasmo en nuestras fiestas de carnaval, indudable que es una tradición que nos identifica como jalostotitlenses, que, en otrora era un orgullo la manera de celebrar y convivir en el carnaval, destacaba la elegancia y el pudor con que vestían la mujer Jalostotitlenses, sin embargo en este tenor no olvidemos que estas fiestas son un legado de quienes nos enseñaron e inculcaron los valores morales y religiosos, que son en suma la identidad del Alteño. $^{184}$

En este artículo se observa una fuerte crítica al libertinaje durante el carnaval. E libertinaje de los participantes de las fiestas es una conducta preocupante, dado que emite una imagen de Jalostotitlán diferente de la que quieren conservar aquellos habitantes que creen en los valores religiosos y está perjudicando la "buena imagen" de la celebración del carnaval que es una tradición que forma parte de la identidad jalostotitlense. Por lo tanto, el libertinaje se entiende como un "problema social".

Los comportamientos de los participantes de las fiestas, sobre todo, los comportamientos de los jóvenes que se interpretan por lo general en nivel local como libertinaje son el exceso de consumo de bebidas alcohólicas y el ruido que causan la música de banda callejera que contratan los jóvenes ausentes y el sonido de alto volumen del estéreo de los coches que circulan en las calles de la

${ }^{184}$ Expresión de los Altos, año 3, marzo de 2003, p.1. 
ciudad. Como había comentado en el capítulo 2, estos comportamientos están estrechamente ligados con los significados que los jóvenes ausentes dan al carnaval y a las fiestas de agosto. Para ellos, estas festividades locales son una ocasión de gozar del "espacio de libertad" saliendo de la cotidianeidad sujeta a las normas sociales estrictas y al trabajo en Estados Unidos, experimentar el cambio efímero en su estatus social a través de su capacidad de consumo y de iniciar o renovar el noviazgo. Pero esta nostalgia de los jóvenes se satisface en Jalostotitlán básicamente a través del consumo en bares, cantinas, discotecas, el recorrido con las bandas de música en las calles de la ciudad y la participación en algunos eventos de las fiestas locales. Por lo tanto, estos comportamientos de los jóvenes ausentes han sido un factor importante que levanta el comercio local. De hecho, los propietarios de sitios nocturnos, bares y cantinas buscan el mayor ingreso del año en temporada de fiestas locales. La mayoría de las discotecas y los bares populares tanto entre los jóvenes locales como entre los jóvenes ausentes se abrieron en los años noventa, la década en que ya era muy notoria la creciente presencia de los jóvenes ausentes en Jalostotitlán en temporada de fiestas locales.

Como había explicado en el capítulo 3, el retorno temporal masivo de los ausentes radicados en Estados Unidos para asistir a las fiestas locales se generalizó desde la segunda mitad de los años ochenta. Los jóvenes ausentes se han incorporado en las corrientes de retorno en dos formas: en primer lugar, muchos migrantes jóvenes que salieron hacia Estados Unidos después de esta década han tenido la facilidad de arreglar sus papeles y encontrar trabajo y hospedaje debido a la antigüedad migratoria de sus familias y han participado en las corrientes masivas dirigidas hacia Jalostotitlán en temporada de fiestas locales; en segundo lugar, en los flujos de retorno ha participado la segunda generación de migrantes acompañando a sus padres o viajando con sus primos y amigos. Esto es la razón por la cual ha aumentado el número de los jóvenes ausentes en Jalostotitlán durantes las fiestas locales en las últimas dos décadas.

Sin embargo, la reincorporación de la nueva generación de los jalostotitlenses que busca el "espacio de libertad" a la vida local ha provocado 
reacciones fuertes de los lugareños con respecto a los comportamiento de los jóvenes. En la revista local, se observan varios artículos de quejas y reclamos que enviaron los habitantes de Jalostotitlán.

muchos jóvenes se pierden en el alcoholismo y la drogadicción, estos son males que van en aumento y están a la vista de todos. ¿Habrá calidad de vida cuando la vida se destruye por los vicios? ${ }^{185}$

Ya no es novedad observar a individuos con bebidas embriagantes en mano e ingiriendo en la vía pública sin que se tomen cartas en el asunto. ${ }^{186}$

\section{¡Dí Basta!}

A la contaminación auditiva por las calles de la ciudad

Recogemos el reclamo de numerosos ciudadanos que manifiestan su malestar por el continuo transitar durante todo el día -se agudiza el fin de semana- de individuos con el ruido insoportable que traen en sus vehículos, incluso en horas de la madrugada. Consideramos que en muchas ocasiones es tal el ruido que rebasa lo soportable al oído, en caso de no obtener respuesta satisfactoria el siguiente paso es aplicar la ley en materia. Es necesario que la autoridad reflexione al respecto para que comience una campaña para concientizar a quienes infringen esta norma.

Agrupación Jalostotitlense Pro-defensa de nuestros valores y tradiciones A.C. ${ }^{187}$

Además del sonido alto de los vehículos que circulan en las calles de la ciudad, las bandas de la música callejeras que contratan los jóvenes son también considerados como "contaminación auditiva" por muchos habitantes del centro de la cabecera municipal. De hecho, en los años recientes había muchas peticiones de los habitantes a la presidencia municipal de que el sonido de la música de las bandas callejeras no los dejaba dormir bien durante las fiestas de agosto, dado que casi toda la noche las bandas recorrían las calles del centro. Ante esta situación, en agosto de 2004, la presidencia municipal estableció un decreto de restringir a las bandas sus actividades comerciales después de las 2:00 de la mañana durante la primera quincena de agosto. Sin embargo, para el gobierno municipal, es un asunto delicado porque en este problema de contaminación auditiva están involucrados dos grupos, es decir, los ausentes y los habitantes de la cabecera municipal. Los ausentes regresan a su terruño para desahogarse del

\footnotetext{
185 Expresión de los Altos, año 3, marzo de 2003, p.2.

${ }^{186}$ Expresión de los Altos, año 3, diciembre 2002, p.4.

${ }^{187}$ Expresión de los Altos, año 3, diciembre 2002, p.10.
} 
estrés y el cansancio acumulado en su vida en Estados Unidos. El recorrido que hacen con la música viva de la banda en las calles de la ciudad les permite llamar la atención de los demás y sentir la libertad haciendo comportamientos que no pueden hacer en Estados Unidos (por ejemplo, tomar alcohol en espacios públicos y celebrar la fiesta con el altísimo volumen del sonido de la música). Pero, en Jalostotitlán hay personas que tienen que descansar en la noche para trabajar o realizar sus actividades al día siguiente. Si el gobierno municipal, no hiciera nada para atender a sus peticiones, los habitantes pensarían por qué se está dando tanta facilidad a los ausentes, no a quienes viven en el municipio. Por eso, la presidencia municipal tiene que buscar una medida en la que se tome en cuenta el equilibrio entre los intereses de ambos grupos.

Otra preocupación de muchos habitantes de la cabecera municipal durante las fiestas locales, sobre todo, las fiestas de agosto es que el libertinaje no es objetivo ni adecuado para la celebración de las fiestas de carácter religioso. Por ejemplo, en la revista local aparece el siguiente artículo de quejas de los habitantes de Jalostotitlán:

Ya no son como antes

Nuestro terruño y todos los jalostotitlenses celebramos, durante este mes de Agosto, con fervor y entusiasmo la fiesta en honor a la Santísima Virgen María, Madre de Dios en su advocación a la gloriosa Asunción.

Como es una tradición de muchos años, es la fiesta en que concurren en mayor número los hijos ausentes para reencontrarse con la tierra de sus mayores, no así se da este reencuentro con la manera como ya algunos de las nuevas generaciones han contribuido a la descomposición o desvirtuación de lo que en esencia debe ser la fiesta de Agosto en Jalostotitlán.

Existen elementos que permiten fundamentar como ya individuos o grupos ajenos a la población incluso. Se han empeñado en no respetar la religiosidad y el recato que deben privar en nuestras fiestas de Agosto, por el contrario es la constante durante la quincena observar a individuos con bebidas embriagantes en mano ante la pasividad de una autoridad que sólo hace que no ve al no aplicar la ley en materia, por lo cual es irritable el desenfreno y escándalo a todas horas del día, y se acentúan aún más esa irritación, por tratarse de unas fiestas de índole religioso. ${ }^{188}$

Aunque las fiestas de agosto son de carácter religioso, el motivo del retorno temporal de los ausentes radicados en Estados Unidos para la participación en estas fiestas durante sus vacaciones de verano, como expliqué en el capítulo 3, no

${ }^{188}$ Expresión de los Altos, año 4, agosto de 2003, p1. 
es únicamente religioso. Hay otros motivos importantes del retorno durante las fiestas, tales como, el reencuentro con los miembros de la familia, amigos y novios, la renovación de lazos sociales, la reafirmación del sentido de pertenencia, la transmisión de tradiciones y costumbres de su tierra natal a la nueva generación, la búsqueda de la experiencia de liberación de la cotidianeidad en Estados Unidos. El énfasis que ponen los individuos entre estos múltiples motivos del viaje a su lugar de origen varía dependiendo de edad, la etapa del ciclo de vida y género. El reencuentro con los amigos de infancia, la experiencia de suspensión de la cotidianeidad sujeta a estrictas normas sociales y a la lógica de trabajo en Estados Unidos, la experiencia del cambio efímero en el estatus social y el comienzo y la renovación del noviazgo son las expectativas que se buscan particularmente entre los jóvenes ausentes durante las fiestas de agosto. Son las mismas expectativas que se buscan en el carnaval, y a lo mejor con más legitimidad que en las fiestas de agosto porque una de las características del carnaval como ritual es el rompimiento temporal con las normas sociales de la vida cotidiana a través del exceso, el consumo de bebidas embriagantes y el placer mientras que las fiestas patronales son un ritual cuyo principal objetivo es la reafirmación de la creencia, los valores y normas religiosos. En este sentido, en las fiestas de agosto hay la dimensión en que se penetra la lógica del carnaval, de alguna manera, se observa la "carnavalización" de las fiestas patronales. A este proceso contribuye el sector de comercial local que ofrece a los jalostotitlenses los servicios para realizar las expectativas de los jóvenes sobre las fiestas de su lugar de origen, dado que para los propietarios de cantinas, bares y discotecas, las fiestas de agosto son también una temporada alta en la que se busca el mayor ingreso del año.

Sin embargo, la proliferación de las actividades de los jóvenes para realizar sus expectativas de las fiestas religiosas se interpreta como "descomposición" o "desvirtuación" de la esencia de las fiestas de agosto tanto por la iglesia local como por aquellos jalostotitlenses que dan mayor importancia al carácter religioso de las fiestas, sobre todo, por las generaciones que conocían las fiestas de agosto de las épocas anteriores a la segunda mitad de los años ochenta, desde la cual ha sido notoria la creciente presencia de las actividades no religiosas de los jóvenes 
en el centro de la cabecera municipal durante las fiestas patronales y ha crecido el auge comercial en temporada de fiestas locales. Durante el trabajo de campo, muchos de los habitantes locales y los migrantes que ya pasaron la etapa de juventud me comentaron que antes las fiestas de agosto eran más tranquilas y la diferencia entre el carnaval y las fiestas de agosto era muy notoria. Manifestaron la añoranza por las fiestas de agosto de épocas anteriores y a la vez la crítica a la manera en que ahora celebran los jóvenes las fiestas de agosto.

\section{SURGIMIENTO DE IDENTIDAD LOCAL ESCENCIALISTA}

Por su parte, el aumento del alcoholismo y la drogadicción y el cambio en el modo de vestir, actitud, visión del futuro y forma de pensar entre los jóvenes locales han sido considerados tanto por el gobierno local como por los habitantes de la cabecera municipal como otros "problemas sociales" provocados como consecuencias del impacto del fenómeno migratorio y de la penetración de las influencias negativas derivadas de Estados Unidos en la vida local. En el informe de la presidencia municipal publicado en 2002 , hay la siguiente observación del impacto del fenómeno migratorio en la vida local:

Nuestro municipio por su necesidad de ingreso económico tiene una gran población emigrante que nos provoca severos problemas de transculturación que repercuten en las buenas costumbres de las familias, a su vez en la proliferación de adicciones, y estilo de vida no acordes a nuestros principios. ${ }^{189}$

En esta descripción se observa el término "transculturación". Como expliqué en el capítulo 1, este término fue elaborado originalmente por el antropólogo cubano Fernando Ortiz para captar la dinámica de procesos de cambio cultural a través del contacto entre poblaciones históricamente separadas bajo una relación de poder asimétrica. Según él, hay dos diferentes formas de narrativa sobre el cambio cultural: la primera forma es aquella narrativa que interpreta el cambio cultural como "deculturación" o destrucción de la cultura de un grupo de poblaciones por las influencias del otro grupo externo; la segunda es aquella narrativa de creación de nuevas formulaciones culturales a través de la mezcla y

${ }^{189}$ Plan de Desarrollo Municipal, Jalostotitlán, 2002, p.4. 
la yuxtaposición de personas y elementos culturales diferentes. El término que aparece en la descripción anterior se usa en el primer significado de transculturación. En otras palabras, aquí, la transculturación se entiende como las influencias negativas del país del norte y de la migración en la vida local, sobre todo, en el modo de vida de los jóvenes, las cuales contribuyen a la pérdida de valores y tradiciones locales.

El alcoholismo, el consumismo y la deserción escolar entre los jóvenes son problemas entendidos como consecuencia de la valoración exagerada del "Norte" entre los habitantes de la cabecera municipal por aquellos habitantes que relacionan el cambio cultural entre los jóvenes con la migración. Por lo general se piensa que para muchos jóvenes locales, ir a Estados Unidos es como una "marca". El "Norte" es un símbolo del destino que les permite tener más experiencias nuevas, más riquezas materiales y un mejor estatus social que pueden presumir a los demás. Ir al Norte es un sueño de vida exitosa muy real para aquellos jóvenes lugareños que han crecido en Jalostotitlán observando los productos, las camionetas y el dinero que traen los migrantes y su capacidad de consumo y pensando que los hombres más atractivos para las muchachas de aquí son los que vienen de Estados Unidos. Esta valoración exagerada del "Norte" ha llevado a los jóvenes a imitar los comportamientos de los norteños, frecuentar a las cantinas, bares y discotecas, caer en el exceso de consumo de alcohol, el libertinaje, creer que es mejor ir al Norte en vez de seguir estudiando o buscar el empleo en México y dejar su tierra natal desde temprana edad para trabajar en Estados Unidos.

Otro problema social que se entiende como consecuencia de las influencias de Estados Unidos es la proliferación de los jóvenes que se visten y actúan como cholos.

\section{¡Di Basta!}

Manifestamos nuestro desagrado y repudio a las actitudes antisociales de algunas de los individuos que se identifican como "cholos".

Esta "Fauna social" importan formas de conductas y comportamientos ajenos a nuestra identidad y a nuestra cultura, actúan (una de sus fechorías) de manera vandálica y nociva en contra de bienes particulares así como en bienes y monumentos públicos. 
La ciudadanía y gobierno juntos debemos de evitar que esta "escoria" de la sociedad prosiga en su afán de perjudicar el patrimonio de nuestro hogar que es Jalostotitlán.

Asociación Jalostotitlense pro-defensa de nuestros valores y tradiciones A.C. ${ }^{190}$

Según un informante que vive en Jalostotitlán, quien está a favor de la conservación de los valores religiosos y las tradiciones locales, la razón por la cual los cholos se interpretan como problema social es que esta cultura juvenil derivada de los barrios mexicanos en Estados Unidos representa la violencia, la rebeldía contra las tradiciones y el consumo de droga, por lo tanto, no encaja en la vida local arraigada en el respeto a los mayores, en los valores religiosos y en las tradiciones heredados desde generaciones anteriores.

Por su parte, de esta forma negativa de interpretación sobre el impacto de la migración en la vida local ha surgido la representación de identidad jalostotitlense construida a partir de la oposición con las influencias del Norte. En 1996 se publicó en Jalostotitlán un libro titulado Cuadro estadístico de la municipalidad de Jalostotitlán 1880. Juan Macías Gutiérrez, quien nació en Jalostotitlán en 1846, era el autor que hizo un manuscrito sobre su tierra natal. Más de 100 años después, este texto se publicó como libro por los Amigos de la Historia de los Altos de Jalisco, A.C., un grupo de los estudios históricos de la región. José Antonio Gutiérrez Gutiérrez, historiador originario de Jalostotitlán, aporta un estudio introductorio para hacer una breve presentación del contexto histórico de Jalostotitlán del siglo XIX, la biografía del autor y su obra. Lo que quiero señalar de este libro son las primeras tres páginas de la introducción escrita por el historiador.

José Antonio Gutiérrez Gutiérrez comienza la introducción del libro con una narrativa sobre el apego a la tierra natal, a sus tradiciones y a la identidad local.

El arraigo a la tierra es el tronco común que une a los jalostotitlenses. Por circunstancias muchas veces inexplicables, avatares del tiempo, despego y hasta resentimiento, vivimos en países o regiones extraños alejados de la familia; pero en el fondo, guardamos nuestra identidad con Jalos, con la sociedad que nos vio nacer o tenemos nuestras raíces. Este asimiento al origen, orgullo de "ser", conciencia de "formar parte" de este pueblo nuclear alteño, nos convierte en nacionalistas, porque sentimos, defendemos y traemos dentro las tradiciones locales que son las más

${ }^{190}$ Expresión de los Altos de Jalisco. Año 4. Agosto 2003. p.2. 
mexicanas. Y por eso, al sentir el jalón de nuestro origen volvemos con frecuencia a ver a esta tierra donde todos somos una familia. ${ }^{191}$

Aquí, el historiador señala que el apego a la tierra natal y a las tradiciones locales es lo que hace a los jalostotitlenses que viven en otras regiones y países volver a su terruño y lo que los convierte en "nacionalistas" que defienden las tradiciones locales caracterizadas como "las más mexicanas". En el siguiente párrafo, explica el papel importante que juega la historia en la conservación de las memorias de la tierra natal y el apego a ella:

Mientras más conozcamos su historia, mejor conservaremos la adhesión al origen, a la tierra de nuestros mayores, al terruño que nos vio nacer. Cuando lejos, su recuerdo pulula en los ratos de quietud, en noches silenciosas, la imagen de este pedazo de tierra en que vimos la primera luz, crecimos y coronamos nuestros ideales infantiles y de juventud, difícilmente se borra por las indisolubles ligas que ha creado. Este amor a Jalos incita a que quienes conservamos alguna raíz, nos interesemos por profundizar en su historia y porque otros también la conozcan. Nos empeñamos por que gente extraña la conozca, que estudie nuestra comunidad y la ofrezcan con una perspectiva nueva en vísperas del tercer milenio. ${ }^{192}$

El historiador tuvo la experiencia de vivir la separación de Jalostotitlán y él mismo es un ausente radicado en Aguascalientes. En esta descripción se refleja la nostalgia hacia sus recuerdos de la infancia y juventud en su tierra natal que él mismo ha vivido desde una distancia espacio-temporal. En la siguiente página, expresa al lector una narrativa de nostalgia que surgió de su observación sobre el cambio cultural que se ha dado en su lugar de origen en los últimos años:

Nos angustia ver cómo se destruyen valores e historia, y que autoridades y sociedad se desentienden de enseñar nuestros valores a la niñez y juventud. Seamos realistas, la cultura alteña está soportando golpes demoledores de sus propios hijos. Los cambios e influencias que aprenden nuestros coterráneos en el país del norte y que vienen a imponer, están arruinándola y acabando con ella. Vemos con dolor que de no hacer algo, y pronto, quizá nos toque verla morir bajo el influjo anglosajón. De no rectificar el camino, posiblemente presenciemos su fin y seremos quienes registremos su muerte. ¡Es tiempo de esforzarnos porque éste no ocurra! Quienes vislumbramos este peligro, debemos reclamar con energía una esmerada atención al problema.

\footnotetext{
191 Gutiérrez Gutiérrez (1996: 7).
}

192 Gutiérrez Gutiérrez (1996: 7) 
A los alteños nos gusta defender y exaltar con pasión lo nuestro, nuestra tierra fuera; en cambio en nuestro lugar de origen dejamos que la conculquen ideas extrañas en aras de una libertad mal entendida. Es tiempo de alertar esta campaña de transculturación traicionera. La libertad de costumbres que con frecuencia hace perder la mesura, hay que reclamar, no es sino una instrumentada campaña por colonizarnos también culturalmente. Pero como dice el refrán, no es culpa del indio, sino de quien lo hace compadre. El camino para que recupere el alteño su identidad está en conocer a fondo su historia, su cultura. Sólo así fortalecerá su ser y no perderá el rumbo. ${ }^{193}$

Por un lado, interpreta que las influencias que traen sus paisanos de Estados Unidos son la causa principal del cambio cultural de Jalostotitlán. Para él, este cambio tiene una connotación negativa, se entiende como "transculturación traicionera" o "colonización cultural", dado que las influencias del Norte están "destruyendo" los valores, tradiciones e historia locales que son elementos fundamentales de la esencia de la identidad local. Por el otro lado, propone una identidad local a partir de la oposición y el rechazo de las influencias negativas de Estados Unidos y la importancia de los estudios de la historia y la cultura local en la defensa de los valores y las tradiciones locales ante el proceso de penetración de las prácticas culturales y sociales derivadas del país del norte en la vida local.

Cabe mencionar que aunque en estos análisis por parte del gobierno municipal y del historiador sobre los cambios socioculturales en la vida local se busca la principal causa de "problemas sociales" entre las influencias de Estados Unidos y el impacto del fenómeno migratorio, las miradas de estos actores hacia Jalostotitlán no sólo descansan en el pasado de la localidad antes de los cambios recientes y la realidad del presente, sino también hacia el futuro. En la descripción de los textos del gobierno municipal y del historiador, se encuentran algunos mensajes de cómo resolver estos "problemas sociales" y cómo fomentar el apego a los valores y las tradiciones locales para cambiar la realidad del presente. Por ejemplo, en un diagnóstico realizado por el gobierno municipal en los años recientes, por un lado, se observa la interpretación negativa del impacto de la migración en la nueva generación de los habitantes de Jalostotitlán, y por el otro lado, se manifiesta la importancia del fomento de actividades creativas y culturales en el municipio para la orientación de los jóvenes locales hacia un desarrollo social

${ }^{193}$ Gutiérrez Gutiérrez (1996: 8) 
y humano "más integral" ante el cambio en el estilo y la visión de vida entre los jóvenes como un producto de transculturación provocado por el fenómeno migratorio:

La emigración a E.U.A. es un fenómeno que ha dejado una profunda huella en nuestra comunidad [...] Todo ello ha provocado una transculturación que se percibe en la utilización de usos y costumbres propios de E.U.A. como lo son la vestimenta y algunas expresiones "agringadas". Todo ello hace que la mayoría de los jóvenes tomen para sí estilo de vida y convivencia que están causando la pérdida de valores y tradiciones propias de nuestro pueblo invirtiéndose estos de manera que adquiera ya más importancia el TENER que el SER.

Cabe mencionar que esto ha provocado en muchas personas de nuestra población una visión de progreso muy pobre, al considerar innecesaria la inversión de capital familiar en la formación y estudios de sus hijos, pues llegada la etapa de transición de la adolescencia a la juventud, los muchachos emigran hacia al país vecino en busca de mejores oportunidades económicas coartando con ello los ánimos de superación que pudieran surgir en estos.

Regularmente el desarrollo de actividades creativas y culturales se da más en un porcentaje mayor entre los niños puesto que cuentan con el acompañamiento de los adultos, en este caso, de sus padres o tutores.

[...] Existen en el municipio personas con iniciativa y propuestas propias, que con esfuerzo y talento realizan actividades culturales en campos como la música, la pintura, el teatro, la escritura, la escultura y la producción de cortometrajes con equipo convencional. En algunas instituciones de educación media superior se imparten algunos talleres de danza, música y periodismo.

El objetivo del Gobierno Municipal es impulsar un mayor número de actividades que contribuyan a un desarrollo social y humano más integral, apoyando acciones que promuevan la educación y el quehacer cultural por medio de programas para el aprendizaje, difusión y exposición de las expresiones artístico-cultural y estas se manifiestan en el apoyo a los talleres que se imparten en la Casa de la Cultura tales como: danza folclórica, pintura, música y canto, mismos que han tenido gran aceptación entre algunos jóvenes. ${ }^{194}$

Por su parte, partiendo de la nostalgia hacia el pasado y de la interpretación negativa de las influencias del Norte, José Antonio Gutiérrez Gutiérrez (1996) también mira hacia el futuro y tiene esperanza en detener a los recientes cambios socioculturales de la vida local:

Hace unos meses tuve la suerte de encontrar arrumbado y polvoriento, mezclado entre papeles que hacen referencia a comunicados de las autoridades eclesiásticas de Guadalajara y cofradías de Jalos, el manuscrito "Cuadro Estadístico de la Municipalidad de Jalostotitlán", de Juan Macías Gutiérrez [...] Ahora que se pone por primera vez en circulación este documento lleno de amor y enseñanzas

${ }^{194}$ El texto titulado "Diagnóstico" que obtuve en la Casa de la Cultura de Jalostotitlán durante el trabajo de campo realizado en el año 2003. 
nuestras, es una ocasión oportuna para exigir que se atienda la conservación de la cultura alteña.

[...] Estamos seguros que por su contenido, lectura amena y reflexiones resultará provechosa a nuestra juventud tan necesitada de profundizar en su pasado. Aunque hace más de cien años que se escribió, siguen siendo válidas sus enseñanzas y su lectura no resulta anacrónica, pues muchos de sus datos servirán para reforzar nuestras tradiciones y darán luz a quienes emprendan cualquier tipo de estudio sobre el municipio, o quiera reafirmar su conocimiento histórico.

[...] hacemos votos por que su lectura coadyuve para recuperar nuestra identidad que peligra ante el influjo anglosajón. ${ }^{195}$

Como estas descripciones demuestran, las narrativas que hacen estos actores sobre el cambio cultural con un tono nostálgico, no sólo se dirigen hacia el pasado y el presente, sino también hacia el futuro. En el caso de la narrativa nostálgica del historiador, es evidente que su interés en la historia y su mirada hacia el pasado son un acto de imaginar un futuro de su tierra natal. Desde su presente mira hacia atrás y hacia el pasado para luego mirar hacia adelante e imaginar desde su presente un porvenir. En este sentido, esta forma de nostalgia como una reacción fuerte a los procesos transnacionales por parte del sector de la población jalostotitlense que no participa directamente en la migración hacia Estados Unidos, se puede entender como una forma de crítica cultural sobre la realidad presente de Jalostotitlán que propone un terruño imaginario, un desafío o una esperanza en el futuro a partir del enfoque en los intereses en la conservación de lo local pero haciendo un recorrido entre varios puntos del eje temporal.

\section{RESPUESTA DE LOS MIGRANTES}

Sin embargo, esta forma de interpretación negativa que se difunde en Jalostotitlán acerca de la migración y los migrantes radicados en Estados Unidos ha causado una polémica entre ellos, debido a que estas interpretaciones negativas que aparecen en los textos publicados localmente sobre el impacto de la migración en la vida local, dirigen las críticas a los ausentes y los culpan de manera implícita o explícita por haber alterado los valores tradicionales y la cultura local. Durante el trabajo de campo en California, algunos migrantes me

${ }^{195}$ Gutiérrez Gutiérrez (1996: 8-10). 
comentaron su inconformidad con este tipo de interpretación sobre el cambio cultural en Jalostotitlán.

Un migrante que trabaja en el condado de Orange me comentó que se había sentido muy ofendido al ver esta forma de interpretación negativa sobre la migración y los ausentes y no estaba de acuerdo con la idea de que Jalostotitlán había sufrido de cambios socioculturales por las influencias negativas de la migración, dado que muchos de los ausentes radicados en California trataban de conservar las prácticas religiosas de su tierra natal a pesar de vivir en otro país. Para él, la migración, sí, ha contribuido a algunos cambios de Jalostotitlán, pero no es la causa principal de los cambios recientes entre los jóvenes, porque la migración ha existido a todo lo largo del siglo XX en su lugar de origen. A finales de los años veinte, durante la guerra cristera, sus abuelos vinieron a California. En los años cincuenta, la mitad de sus tíos vivían en California. En los años sesenta, su padre, sus hermanos y él mismo llegaron a este estado del país del norte. Pero, hasta principio de los años setenta, observaba que la vida de Jalos seguía siendo la misma que en su infancia. Para él, Jalos comenzó a sufrir de un gran cambio cuando se metió la televisión en la vida local.

Un migrante jubilado que lleva casi 40 años viviendo en el condado de Los Ángeles y ha participado activamente en la organización de las fiestas del 15 de agosto en el sur de California tampoco estaba de acuerdo en que los ausentes radicados en Estados Unidos eran causantes principales de la "destrucción" de los valores tradicionales, la cultura y la historia local de su terruño. Comentó que hasta cierto punto, la idea de que la migración tenía un impacto negativo en el cambio cultural tenía razón porque había personas que perdieron las costumbres de su lugar de origen al vivir en el país del norte, pero esto no se podía generalizar ni se podía decir que únicamente los ausentes eran quienes tenían la culpa del cambio de los comportamientos de los jóvenes porque la mayoría de los ausentes seguían con las costumbres de Jalos y con su raíz y sus hijos también seguían con muchas de las costumbres de su lugar de origen.

Retomando la opinión de sus paisanos de California sobre la inconformidad con este tipo de interpretación negativa que se difunde en Jalostotitlán acerca de 
los ausentes de Estados Unidos, un migrante jubilado del condado de Orange elaboró una carta en la cual se encuentra el siguiente mensaje:

Los ausentes regresamos cada año, y con tristeza vemos que somos blanco de críticas, y escritos que nos lastima, es por personas que nunca nos han visitado, deberían de visitarnos, y así analizar y saber que si guardamos nuestras costumbres y nuestros jóvenes estudian y trabajan en buen porcentaje. [Nos] culpan de destruir valores, historia, y de dañar la cultura alteña [...] Seamos conscientes, ya lo hemos dicho, debemos de comprendernos más, para evitar malas interpretaciones que nos lastiman.

Comunidad Jalostotitlense en E.U.A. ${ }^{196}$

Como había comentado en la introducción de este capítulo, a principios de la investigación, planteé un esquema de contienda entre los ausentes y los lugareños en torno a la forma de significación de la imagen de Jalostotitlán. Durante el trabajo de campo en Jalostotitlán y en California, de alguna manera, pude recolectar datos etnográficos adecuados tanto de parte de la población no migrante como de parte de los ausentes para reunir piezas que arman este esquema de oposición entre dos categorías sociales de población jalostotitlense. Como demuestran estas narrativas de los migrantes, sí, se observa la tensión entre ellas que ha surgido de las polémicas sobre las interpretaciones sobre los cambios socioculturales en Jalostotitlán. Sin embargo, al analizar las narrativas de los migrantes que pasaron la juventud ya hace décadas y al fijarme en la etapa del ciclo de vida en que se encuentran aquellos sujetos que se preocupan del libertinaje e insisten en la conservación de los valores y tradiciones locales, me di cuenta de que el análisis de estas polémicas entre distintas formas de nostalgia debería de ir más allá del esquema de oposición entre dos grupos sociales que yo había planteado.

\section{DESPLAZAMIENTO DE PUNTO DE VISTA EN DIFERENTES ETAPAS DEL CICLO DE VIDA}

La primera razón por la cual cuestioné la aproximación al entendimiento de las polémicas que se discuten entre los migrantes y la población no migrante en

${ }^{196}$ En el trabajo de campo que realicé en otoño de 2004, obtuve la copia de esta carta de reclamo del mismo migrante que la escribió. 
torno a la preocupación social sobre los cambios socioculturales entre las nuevas generaciones a partir del simple esquema de oposición de dos categorías sociales de los jalostotitlenses, es que las críticas y la preocupación sobre los comportamientos de los jóvenes durante las fiestas no sólo surgen de aquellos actores locales que tienen interés en la conservación de los valores tradicionales de Jalostotitlán, sino también de algunos migrantes adultos. Por ejemplo, un migrante en la edad de los cuarentas radicado en Anaheim comentó que les decepcionaba a los ausentes ver las fiestas de agosto con tanto libertinaje de los jóvenes y mucha música en las calles, y que antes las fiestas religiosas eran más tranquilas que ahora. El mismo migrante jubilado que escribió la carta anteriormente citada también expresa la misma preocupación del siguiente modo: "La inquietud empieza al llegar a las fiestas de agosto y el carnaval, se preparan para organizar, la famosa tolerancia para adolescentes y jóvenes a favor del vicio."

En lo que quiero enfocarme aquí es la etapa del ciclo de vida, donde se encuentran los migrantes que se preocupan por los comportamientos de los jóvenes. Estos migrantes adultos hablan sobre su preocupación e interpretan los comportamientos de los jóvenes como libertinaje desde el "punto de vista de adultos", es decir, desde el posicionamiento de sujetos que ya pasaron la adolescencia hacía tiempo, se casaron y ahora consideran que la responsabilidad de la familia y la transmisión de los valores religiosos a la siguiente generación son códigos importantes de comportamientos y normas sociales. Este punto de vista justamente coincide con el de aquel sector conservador de la población no migrante, que también se encuentra en la misma etapa del ciclo de vida. Ambos grupos dan significados negativos a los comportamientos de los jóvenes de hoy y manifiestan su preocupación sobre el libertinaje desde el "punto de vista de adultos".

La segunda razón por la que decidí analizar las polémicas entre varias interpretaciones sobre los cambios socioculturales entre los jóvenes jalostotitlenses a partir de la diferencia generacional es que al revisar las narrativas de algunos migrantes sobre sus recuerdos de juventud me di cuenta de que los comportamientos de los jóvenes que se entienden como libertinaje, que es 
el tema central de las polémicas, no son necesariamente características esenciales de la juventud actual.

Durante el trabajo de campo, recolecté las entrevistas de varios migrantes jubilados en las cuales comentaron sus recuerdos del viaje de retorno a su tierra natal durante las fiestas locales cuando eran jóvenes y solteros. Un migrante radicado en Sacramento, quien tenía 72 años en el momento de la entrevista realizada en agosto de 2004 en Jalostotitlán, comentó que cuando era joven, muchos migrantes de su edad, igual que los jóvenes de hoy, gastaban su dinero para tomar bebidas alcohólicas y agarrar la música en las calles aunque el tipo de música que les gustaba era diferente de la música que escuchan los jóvenes de hoy. Él mismo gastaba todo el ahorro que traía de Estados Unidos durante las fiestas cuando era soltero, y luego, tenía que pedir dinero a alguien para ir de nuevo a Estados Unidos. Me dijo que cuando uno era joven, sólo pensaba en divertirse en el momento; pero, al mismo tiempo, el retorno era la ocasión de recibir el regaño de los padres para corregir los comportamientos por vivir sólo el momento; después de casarse y tener hijos, uno tenía que administrar el dinero y ser más responsable con la familia, por eso, cambiaba la mentalidad de vivir sólo el presente y ya dejaba el vicio a un lado; para él, lo que les había enseñado su tierra natal durante generaciones era la responsabilidad, la responsabilidad de cuidar a los hijos; aunque la juventud estaba llena de diversiones, uno tenía que trabajar, ganar dinero y vivir por otros después de casarse y tener hijos; después de entrar a esa etapa de la vida, enseñar a sus hijos costumbres de sus padres era uno de los motivos principales del retorno temporal.

Otro migrante jubilado que vive en South Gate, en condado de Los Ángeles, también comentó que cuando era joven, tomaba mucho y agarraba la música en las calles al regresar a su tierra natal durante las fiestas. Pero ahora les toca aguantar los comportamientos de los jóvenes a aquellos migrantes que ya pasaron la juventud hacía décadas. Por la casa donde él y su familia se quedan durante las fiestas en Jalostotitlán se oye durante toda la noche el ruido de la banda callejera, y no los deja dormir bien durante las fiestas. Me explicó que la razón por la que se quejaba de esto tenía que ver con su edad. Antes era muy común escuchar la 
música romántica y de mariachis, pero ahora los jóvenes escuchan la banda. Su generación no comparte el mismo gusto de música que los jóvenes de hoy. Pero, si tuviera veinte años de edad ahora, no le importaría el ruido, él mismo agarraría la música en las calles en toda la noche. Pero ya se casó y tiene hijos y ya pasó esta etapa de vida.

Lo que demuestran estas narrativas de los migrantes jubilados es que los comportamientos de los jóvenes durante las fiestas locales que hoy en día son vistos como libertinaje por el sector conservador de la población jalostotitlense no necesariamente son características privilegiadas de los jóvenes de hoy. Más bien, muchos de los migrantes que ahora son adultos han pasado su juventud, teniendo básicamente la misma forma de disfrutar con las fiestas locales, desde las décadas anteriores al período en que comenzó el retorno temporal masivo de los ausentes en la segunda mitad de los años ochenta. Pero esta forma de celebrar las fiestas era transitoria y cambiaba cuando los migrantes entraban en otra etapa del ciclo de vida.

Aquí cabe recordar la clásico teoría antropológica sobre ritos de paso y el concepto de liminalidad. El término liminalidad es el concepto que propuso Turner (1969) desarrollando la idea de Gennep (1960) acerca de ritos de paso. Según Gennep, hay tres fases o tipos de ritos de paso: la separación, la transición y la integración. En lo que se enfoca Turner es la fase de transición. En esta fase o tipo de rito de paso, el sujeto se encuentra en un estado transitorio indefinible y liminal, en donde ya no tiene el estatus social anterior al rito de paso ni aún tiene uno nuevo. En esta fase, en ocasiones los valores y las normas sociales estructuradas en la vida cotidiana se subvierten y los símbolos culturales de la vida cotidiana se revuelven. De ahí, el sujeto reflexiona sobre los valores esenciales de su cultura y entra en la siguiente fase y regresa a la vida cotidiana asumiendo las normas sociales de la vida cotidiana y teniendo un nuevo estatus social.

Muchos migrantes que ya pasaron su juventud y muchas familias locales que han tenido miembros que se fueron a Estados Unidos desde temprana edad entienden que ahora sus hijos están en una etapa transitoria del ciclo de vida y un 
estado de liminalidad, donde quieren desahogarse del cansancio, el estrés y la soledad que habían vivido en Estados Unidos, los toleran en la mayoría de las veces durante las fiestas y los regañan cuando piensan que sus hijos ya deben de estar en otra etapa del ciclo de vida o sus comportamientos están pasados de cierto límite.

Durante el trabajo de campo en los Altos de Jalisco, tuve la oportunidad de discutir en ocasiones con algunos jalostotitlenses, que pensaban que los jóvenes estaban perdiendo los valores tradicionales al seguir con el libertinaje que proliferaba en Jalostotitlán en el proceso de penetración de las influencias negativas desde el exterior de la localidad, sobre mi opinión de que los comportamientos de la nueva generación de jalostotitlenses incompatibles con los valores tradicionales son características de los adolescentes que están en una fase transitoria del ciclo de vida, pero estos comportamientos cambian y se modifican al entrar en la siguiente fase en la que se convierte en adultos. Las respuestas que me dieron acerca de esta versión se pueden resumir del siguiente modo: es cierto que cuando uno es joven, es más liberal que los adultos, pero, cuando uno se casa y tiene hijos o un nuevo estatus social, por lo general se vuelve más tranquilo y responsable y se comporta según los códigos dominantes de la sociedad; por ejemplo, a pesar de ser el blanco de una fuerte crítica social en Jalostotitlán, actuar y vestirse como cholos es básicamente una parte de la cultura contemporánea de los adolescentes mexicanos, y muchas veces, los jóvenes que se lucen como cholos cambian su forma de peinarse y vestirse después de casarse con las lugareñas; sin embargo, en el contexto contemporáneo en que el proceso de penetración de diferentes estilos de vida, ideas y objetos derivados de otros lugares y países en la vida local se ha intensificado debido al desarrollo de la tecnología de los medios de comunicación y a la globalización, los jóvenes de hoy tienen más oportunidad de conocer una gran variedad de cosas, ideas, valores y estilos de vida incluyendo aquellos que no son compatibles con los valores tradicionales locales, y la desviación de las normas y códigos sociales dominantes durante la adolescencia, aunque sea transitoria, se ha acelerado más que antes. 
Al final de este capítulo, no intento argumentar cuál es realmente el factor determinante que ha cambiado la vida de los jóvenes jalostotitlenses en las últimas dos décadas o si la juventud de hoy ha cambiado en comparación con las décadas anteriores o no, dado que estas cuestiones no son temas centrales de mi investigación. Pero lo que quiero señalar a través de la revisión y el análisis de las polémicas que se han discutido entre los jalostotitlenses en los años recientes acerca de la juventud de hoy es que han surgido distintas interpretaciones entre los jalostotitlenses tanto en el lugar de origen como en Estados Unidos en el proceso de fortalecimiento de vínculos transnacionales entre los ausentes de Estados Unidos y su terruño. Particularmente, los comportamientos de los jóvenes han sido el objeto central de interpretación tanto por parte de los migrantes como por parte de la población no migrante, y han sido vistos, por un lado, como "problema social", "producto de las influencias negativas de la migración", por el otro lado, como desviación temporal de las normas sociales que es característica de una fase transitoria del ciclo de vida.

También se pueden observar diferentes formas de nostalgia construida desde distintos posicionamientos. La imagen de terruño que el sujeto narra con este sentimiento desde cierto posicionamiento no es necesariamente atractiva para los otros, para todos los grupos sociales y para todas las generaciones, y en ocasiones, genera polémicas y provoca otra forma de narrativa nostálgica como la reacción a la primera. Lo que quiero recordar aquí es que la nostalgia es un sentimiento basado en el contraste entre un lugar espacio-temporalmente distante y la presente vida del sujeto, y que la forma de narrativa nostálgica varía dependiendo del posicionamiento en donde se sitúa el sujeto en la vida presente. Hoy en día, como demuestran los casos etnográficos analizados en este capítulo, no hay un único "presente" desde el cual todos los jalostotitlenses narran su nostalgia hacia el terruño, sino que el presente se vive en distintos lugares en distintas formas. Los jóvenes jalostotitlenses de Estados Unidos construyen su nostalgia a partir del contraste con su vida presente en Estados Unidos y viajan a Jalostotitlán buscando una "tierra de libertad", donde puedan liberarse del estrés, el cansancio y las estrictas normas sociales de ese país. Los jóvenes lugareños 
forman su nostalgia hacia el Norte, es decir, su sueño americano a partir de la vida presente de adolescencia en Jalostotitlán, donde los jóvenes que vienen de Estados Unidos realizan su sueño. Aquellos adultos que piensan que las influencias del Norte están "destruyendo" valores tradicionales se preocupan por la conservación de la vida tradicional, critican y rechazan las influencias negativas de la migración, manifiestan su nostalgia hacia el pasado y proponen una identidad local esencialista y excluyente desde la vida presente que viven en México como adultos. Desde el presente en que reciben estas críticas, algunos migrantes desean regresar a un terruño donde pueda haber más entendimiento mutuo entre los lugareños y los ausentes. Al observar los comportamientos de jóvenes de hoy durante las fiestas y al recordar su juventud, aquellos migrantes y lugareños que ya pasaron su adolescencia y ahora se encuentran en otra etapa del ciclo de vida, miran a los jóvenes de hoy con tolerancia y con la añoranza, y en ocasiones con críticas, irritación y regaños.

En este sentido, en el proceso del fortalecimiento de los vínculos transnacionales, Jalostotitlán se ha convertido en una "zona de contacto" entre varios terruños imaginarios e interpretación sobre los comportamientos de jóvenes que se enuncian desde distintos posicionamientos. ${ }^{197} \mathrm{Sin}$ embargo, distintas narrativas nostálgicas, en ocasiones, se contactan con fuertes choques y surgen como críticas sociales y culturales a otras, dado que el terruño imaginario que se construye con la nostalgia es un imaginario que nace de la crítica al objeto con el que contrasta, por lo tanto, esencialmente no es neutral.

Por su parte, este análisis sobre la coexistencia, el choque y las polémicas de distintas interpretaciones e imágenes de terruño entre los jalostotitlenses nos revela otro aspecto importante de las fiestas locales como ritual. Para las personas que participan en este ritual, las fiestas locales son una ocasión de reflexión sobre su cultura, sus tradiciones y su identidad. Turner sostiene que la liminalidad es una fase del proceso ritual donde se observa la creatividad humana y "un estadio de reflexión" sobre aquellas ideas, sentimientos y hechos que los neófitos habían aceptado sin reflexión como algo dado y determinado desde antes (1967: 105). En

${ }^{197}$ En cuanto al concepto de "zona de contacto", véase Pratt (1992). 
el caso de los jalostotitlenses, los sujetos que reflexionan sobre su cultura y sus tradiciones en el tiempo y el espacio ritual no son solamente aquellos jóvenes que se desvían de las normas sociales dominantes de la vida cotidiana durante la fase liminal de ritos de paso y la fase transitoria del ciclo de vida, sino que los adultos también reflexionan desde distintos posicionamientos. A lo mejor, estos reflexionen más que los primeros sobre su cultura y sus tradiciones. Es decir, los comportamientos de desviación de los valores tradicionales entre los jóvenes de hoy durante las fiestas locales, que han sido el tema central de las polémicas y el objeto con el cual contrastan las tradiciones locales dadas, les dan a los adultos una oportunidad para reflexionar sobre cuál es el significado esencial de las fiestas locales y de ser jalostotitlenses y cuáles son los valores importantes de la vida para los jalostotitlenses en el proceso en que se vuelve más visible la creciente presencia de los jóvenes en las fiestas locales a raíz de la generalización del retorno temporal masivo de los ausentes que comenzó en la segunda mitad de los años ochenta.

De aquí surgen un par de dudas: ¿en el proceso de construcción y fortalecimiento de vínculos transnacionales y en el proceso de reflexión sobre la cultura y las tradiciones locales, será posible reconstruir un terruño en donde pueden identificar sus propios terruños imaginarios los sujetos que viven el presente en distintos posicionamientos? ¿Será posible reconstruir un terruño que abrace múltiples puntos de vista y distintos terruños imaginarios, una forma de representación colectiva de identidad local más incluyente y una conciencia colectiva de vivir en una comunidad transnacional? Estas preguntas son lo que exploraré a través del análisis de los casos etnográficos del último capítulo. 


\section{Capítulo 7}

Con los brazos abiertos: Armonización de sentimientos y terruños imaginarios

\section{INTRODUCCIÓN}

"iLa tierra a la que todos quieren volver!' Es una frase que aparece en los folletos de Jalostotitlán que conseguí en la presidencia municipal cuando visité la cabecera municipal por primera vez en agosto de 2000. Durante el trabajo de campo que comencé tres años después y durante el período en que me dediqué a analizar los datos etnográficos, esta frase había sido, en cierto sentido, un quebradero de cabeza que resonaba y aparecía en mi mente en repetidas ocasiones y me planteaba un par de preguntas. ¿A qué se refieren estos "todos"? ¿Cómo es el lugar adonde todos quieren volver?

Estas preguntas se volvían más profundas y fundamentales al reflexionar sobre los procesos de transformación de Jalostotitlán que se han dado en las últimas dos décadas. Como he explicado del capítulo 3 al 5 , desde que comenzó el retorno temporal masivo de los ausentes en la segunda mitad de los años ochenta, esta localidad ha experimentado distintos cambios, los cuales se pueden resumir a los procesos de transformación de Jalostotitlán en el lugar que coincide con las imágenes del terruño que describen los ausentes en su mente a través de distintas formas de nostalgia. El paisaje del pueblo rural de Jalostotitlán de pasado, la imagen del terruño como el lugar de libertad construida a partir del contraste con la vida cotidiana de las zonas urbanas de Estados Unidos y la imagen de la tierra sagrada donde la Virgen de la Asunción reina como centro de la religiosidad y las tradiciones locales, se han materializado en Jalostotitlán en distintas formas, tales como, el reestreno del pueblo rural en el contexto urbano a través de la celebración de eventos que representa la rusticidad mexicana, la reconstrucción del paisaje arquitectónico rústico de la ciudad, la revitalización de algunas prácticas religiosas locales y otras tradiciones, la construcción y la remodelación de iglesias y de instalaciones de eventos festivos, la reactivación del comercio local que ofrece servicio y productos que satisfacen el deseo de los ausentes de consumir signos de terruño. 
Sin embargo, como muestra el caso etnográfico del capítulo 6, en estos procesos de transformación del lugar que se han dado al reincorporar a la población desplazada a Estados Unidos en la vida local, brotaron las críticas por parte del sector conservador de la población local a los cambios socioculturales que se han vuelto notorios entre los jóvenes. Para este sector local, estos cambios se entienden como consecuencias negativas del fenómeno migratorio y como problemas sociales que los ausentes han traído del Norte y se interpreta como "decadencia" de las tradiciones locales y como el desvío de las normas sociales de la sociedad local y del significado esencial de las fiestas locales. Para aquellas personas que manifiestan esta preocupación, Jalostotitlán que está en proceso de transformación es un lugar en donde no necesariamente pueden identificar el apego emocional y la identidad, es decir, el lugar que representa una imagen de la tierra ajena en la que no se refleja su terruño imaginario. De esta reacción local a los recientes procesos de reconstrucción del lugar en el contexto transnacional, ha surgido un discurso de identidad jalostotitlense que se construye a partir de la oposición con los elementos culturales derivados del Norte. En este discurso los flujos de costumbres, estilo de vida e ideas que viajan con los migrantes desde el país del norte se consideran como "invasión cultural" y los migrantes se describen como "otros" que están excluidos de la identidad local. Pero también surgió la polémica entre los ausentes radicados en Estados Unidos como una respuesta a este discurso local sobre identidad.

Al revisar esta tensión social y polémicas que se han generado entre los migrantes y la población no migrante de Jalostotitlán en los procesos de reconstrucción del lugar de origen en los últimos veinte años, no es fácil contestar a las cuestiones sobre quiénes son aquellos "todos" que quieren volver a Jalostotitlán y cómo sería la tierra a la que todos quieren volver. Aquellas personas que quieren volver al terruño no son solamente los migrantes que conciben la nostalgia a partir de las experiencias de desplazamiento físico y separación espacial y temporal, sino que los habitantes que se lamentan por los cambios que se han dado en Jalostotitlán en los procesos de materialización de terruños imaginarios de los ausentes, también experimentan el sentido de perdida y la 
separación en términos temporales. En este sentido, no todos comparten los mismos imaginarios ni quieren volver a la tierra que representa significados del lugar para un solo sector de los jalostotitlenses. De esta dificultad para pensar en alguna respuesta a las preguntas, me surgieron otras: ¿Sería posible reconstruir el lugar de tal manera que todos los que dirigen las miradas nostálgicas hacia Jalostotitlán desde diferentes posicionamientos puedan encontrar el sentido de pertenencia en este lugar y proyectar sus propios terruños imaginarios sobre esta tierra? ¿Sería posible una narrativa de la identidad local más incluyente y alternativa a la identidad local construida a partir de la oposición con los migrantes y las influencias del Norte? ¿Sería posible construir terruños imaginarios colectivos adonde tanto los habitantes como los ausentes quieran volver?

Para poner fin a estas cuestiones, en este capítulo presento dos casos etnográficos sobre algunas prácticas culturales de las fiestas religiosas de agosto. Estos casos demuestran un ejercicio local que parece llevar a la práctica el eslogan de "la tierra a la que todos quieren volver", redefiniendo la forma de pertenecer a Jalostotitlán más allá del sentido local y buscando una armonización de los sentimientos e imaginarios sobre esta localidad entre los ausentes y los habitantes.

El primer caso etnográfico que se presenta en este capítulo es el evento de la entrega del reconocimiento a los jalostotitlenses distinguidos que se celebra en una exposición local llamada Expo Jalos. Enfocándome en la historia de vida de dos personajes (un ex-migrante y un migrante jubilado) que fueron homenajeados en este evento, explicaré un nuevo discurso local de ciudadanía que reconoce distintas formas de ser jalostotitlenses y de pertenecer a Jalostotitlán. Al hablar de la ciudadanía, no me refiero a la ciudadanía en el sentido jurídico-legal, sino a la ciudadanía cultural. Renato Rosaldo (1994) planteó este concepto para una investigación antropológica colectiva sobre los latinos en algunas zonas urbanas de Estados Unidos, y lo explica del siguiente modo:

El concepto de ciudadanía cultural se refiere al derecho de ser diferente (en cuanto a raza, etnia o lengua materna) frente a las normas de la comunidad nacional 
dominante, sin perjudicar el derecho de pertenecer, en el sentido de participar, en los procesos democráticos del Estado-nación. ${ }^{198}$

En este caso etnográfico de Jalostotitlán, las personas seleccionadas como jalostotitlenses distinguidos no son solamente aquellos individuos que nacieron y viven en esta ciudad, sino que las personas con lugar de nacimiento y de residencia fuera de la localidad también están incluidas como objetos de homenaje. En el caso concreto, estos dos personajes fueron homenajeados principalmente por sus prácticas de crear y fortalecer el vínculo entre los ausentes y el lugar de origen a beneficio de su tierra natal. Aquí se observa el surgimiento de una práctica local de la redefinición de la ciudadanía cultural en el contexto transnacional.

El segundo caso etnográfico que se analiza en este capítulo es la publicación de libros sobre Jalostotitlán cuyos principales lectores son los ausentes. La nostalgia es el tema principal de muchos de los libros publicados y presentados durante las fiestas de agosto en los años recientes. Lo que intentan la mayoría de los autores es la construcción del terruño imaginario colectivo y los sentimientos colectivos hacia Jalostotitlán, es decir, transmitir su propia nostalgia hacia el terruño al lector, construir memorias, sentimientos e imaginarios colectivos sobre Jalostotitlán tanto para los habitantes como para los ausentes y buscar un nuevo camino de reconstrucción de la localidad a partir de sentimientos, memorias e imaginarios compartidos. En este sentido, este movimiento literario es una práctica cultural que fomenta la comunicación entre los habitantes y los ausentes, difunde ciertas formas de nostalgia como sentimiento colectivo entre ellos y la utiliza como capital social y cultural.

En el último apartado, retomando estos dos casos etnográficos, haré una reflexión sobre la dirección hacia la cual estas nuevas prácticas de inclusión llevan el proceso de reconstrucción del lugar y la cultura local en el contexto transnacional.

${ }^{198}$ Renato Rosaldo (1994: 67). 


\section{RECONOCIMIENTO DE NUEVAS FORMAS DE SER JALOSTOTITLENSES}

En la Casa Social que se encuentra enfrente de la Plaza de Armas, del primer fin de semana del mes de agosto al día 16, se celebra la Expo Jalos. Dentro de la instalación hay exposiciones religiosas (exposiciones de vestidos de la imagen de la Virgen de la Asunción que se prepararon en las fiestas patronales en los años anteriores y otras exposiciones de las tres parroquias que existen y del Patronato del Templo de Santo Toribio Romo), artesanales (incrustaciones, madera tallada, deshilados, listón, punto de cruz y bordados), de instituciones (el DIF municipal, H. Ayuntamiento, Caballeros de Colón, el Club Social y Deportivo Jalos, delegaciones municipales, la protección civil, bomberos, la Cruz Roja, la Fundación Jalostotitlán), industrial (muebles, guantes, calzados, forrajes, textil, maíz, impresos, medios de comunicación local, carnes, productos lácteos, etc.) y pictórica (exposición de pinturas de artistas locales). En la Expo Jalos también se realizan varios eventos, tales como, la presentación de baile clásico y el folklórico y de la banda municipal, conferencias históricas y sociales, la presentación de libros, conciertos musicales.

La entrega del reconocimiento a los jalostotitlenses distinguidos es uno de los eventos que se celebran anualmente en la Expo Jalos. En esta ceremonia, el comité organizador de la Expo le otorga, con la presencia del párroco del Templo de Nuestra Señora de la Asunción y el presidente municipal, un reconocimiento a cada uno de los jalostotitlenses en tres de las siguientes categorías: hijo de Jalos (la persona nacida y radicada en Jalostotitlán); hijo ausente (la persona que nació en Jalostotitlán, pero, vive actualmente fuera del municipio o su descendiente radicado en otros lugares), y por último, hijo adoptivo de Jalos (la persona que nació en otro lugar sin ascendencia de alguna persona de Jalostotitlán, pero, ha vivido durante años en Jalostotitlán).

\section{1) Articulador transnacional}

El 13 de agosto de 2003, don Francisco Javier Reynoso Gutiérrez fue homenajeado como hijo de Jalos distinguido en el tercer evento anual de la entrega de reconocimiento por las ayudas sociales que había brindado a beneficio de Jalostotitlán como migrante durante su estancia en Estados Unidos y como 
habitante de Jalostotitlán desde que regresó a su tierra natal a principios de los años ochenta.

Don Pancho emigró a California en 1963 cuando tenía 21 años de edad. A principios de su vida migratoria en Estados Unidos, se dedicó al trabajo en el sector textil. Posteriormente, comenzó a trabajar como representante de la compañía disquera Cronos en la Unión Americana para promover a los cantantes mexicanos de música ranchera en California, Texas e Illinois, los estados en donde se concentraba la población mexicana. De esta empresa, él había recibido varias ofertas de empleo en la Ciudad de México. Pero no las aceptó. En El libro de los talentos, él explicó esa razón: "mi máxima ambición es regresar a vivir a mi pueblo. Vivir ahí tranquilamente y descansar por el resto de mis días, sería para mí la mayor satisfacción de mi vida". ${ }^{199}$ Tal como lo dijo en este libro, después de haber vivido en Estados Unidos durante veinte años, en 1983, decidió regresar a Jalostotitlán para vivir, dado que quería que sus hijos crecieran y se educaran en su pueblo natal. Sin embargo, en vez de descansar tranquilamente, ha sido activo en cuanto a sus actividades sociales y laborales. Participó en varias labores sociales y religiosas y en la fundación de varias asociaciones de trabajadores. En 2004, empezó su nuevo negocio de salón de fiestas "Casa Grande" cuando tenía 62 años. A pesar de que realizó el proyecto de retorno de manera definitiva y ha vivido más de otros veinte años en Jalostotitlán, ha mantenido el vínculo con Estados Unidos y con sus paisanos radicados en California a través de las reuniones familiares y sociales, algunos viajes que hace cada año para la consulta médica en el hospital de Los Ángeles y para pasar vacaciones y sus actividades sociales y religiosas.

Don Pancho me comentó que cuando él había comenzado su vida migratoria en California a principios de los años sesenta, la representación de la identidad social arraigada en Jalostotitlán entre sus paisanos no era tan notoria como hoy en día. De hecho, cuando otros migrantes mexicanos les preguntaban a sus primos y a sus amigos de Jalostotitlán de qué parte de México venían, les contestaban que eran de Guadalajara, pensando que Jalostotitlán era un pueblo pequeño, por lo

199 Jáuregui Pérez (1981: 83). 
tanto, nadie lo conocía. A don Pancho le molestaba esta forma en que sus paisanos ocultaban su origen. No entendía por qué no podían decir con orgullo que eran de Jalostotitlán. Su fuerte localismo y su entusiasmo de hacer Jalos conocido fueron los principales motivos de varias actividades no lucrativas que él ha realizado a beneficio de los ausentes y de su tierra natal durante veinte años de su estancia en California y después de retornar a Jalostotitlán de manera definitiva.

En 1967 fundó el Club Social Jalostotitlán de Los Ángeles junto con sus paisanos que radicaban en el sur de California. Fue electo como primer presidente para la mesa directiva del club. Las actividades principales del club eran la organización del Baile de Coronación de la Reina y la cerebración de las fiestas de la Virgen de la Asunción, las cuales tenían varios objetivos: fortalecer lazos sociales entre los jalostotitlenses radicados en el sur de California; recolectar entre los paisanos la donación con la que se realizaban las ayudas económicas y materiales al lugar de origen y a las familias de escasos recursos económicos de Jalostotitlán, y promocionar el nombre del terruño a través de la invitación de los periodistas y el locutor del programa de radio de Los Ángeles al baile.

En las actividades del club social, don Pancho jugó un papel importante. Él fue quien recomendó al párroco que había llevado a California una réplica de la Virgen de la Asunción, que en vez de hacer una rifa con la imagen entre los jalostotitlenses, la otorgara al Club Social Jalostotitlán de Los Ángeles para que esta réplica perteneciera a todos los jalostotitlenses radicados en el sur de California, a cambio de una donación a la iglesia por parte del club de la misma cantidad del dinero que el párroco pretendía recolectar con la rifa. Fue también quien insistió a otros directivos del club en la necesidad urgente de una ambulancia en su lugar de origen, dado que en Jalostotitlán había muchas personas que se morían en el traslado a otros lugares donde podían recibir una mejor atención médica. La donación por parte del club de la ambulancia se realizó en 1973, con la cual fue posible la fundación de la Cruz Roja en Jalostotitlán.

Además de su participación en las actividades del club, para promover el sentido de pertenencia a Jalostotitlán entre sus paisanos, hacía playeras con el nombre de Jalostotitlán impreso y se las regalaba a sus paisanos a principios de 
los años setenta. También hacía cachuchas con el nombre de Jalostotitlán, grababa las canciones sobre su tierra natal en casetes y se los regalaba a sus paisanos. Registró en el Estado de California la placa de su vehículo con las letras JALOS. En la entrevista, me comentó sonriendo que estaba muy contento de que el negocio de su sobrino Víctor tuviera tanto éxito con la venta de playeras de Jalostotitlán y otros artículos de recuerdo porque esto demostraba que él no estaba loco cuando hacía tantas cosas de Jalos en Estados Unidos.

Después de haber regresado a principios de los años ochenta, también hizo otras labores importantes a beneficio de Jalostotitlán y de los ausentes de Estados Unidos. Aunque en los años ochenta, las actividades del Club Social Jalostotitlán de Los Ángeles prácticamente ya habían terminado, la Cruz Roja de Jalostotitlán consiguió la segunda y la tercera ambulancia de Estados Unidos. Don Pancho y sus amigos de California juntaron el dinero que equivalía a la mitad del precio de la ambulancia y puso otra mitad la Cruz Roja de Jalostotitlán.

En la entrevista, don Pancho me contó su recuerdo del viaje que hicieron él y su amigo, que también fue el presidente del Club Social Jalostotitlán de Los Ángeles, para traer la segunda ambulancia a su tierra natal manejando desde California. De Los Ángeles a Texas, manejaron la ambulancia con la intención de cruzar la frontera en el punto de Presidio, Texas-Ojinaga, Chihuahua. La ambulancia tenía el título pintado de "Cruz Roja Mexicana de Jalostotitlán" y una placa de California. Pero, como ellos no traían ningún documento autorizado para pasar la ambulancia de Estados Unidos a México, el primer intento del cruce fronterizo no se logró. Luego, se fueron a El Paso, Texas, porque sabían que en Ciudad Juárez vivían los jalostotitlenses económicamente bien acomodados que pudieran negociar con el gobierno de México. En el camino a El Paso, don Pancho se encomendó a la Virgen de la Asunción para que los ayudara a cruzar la frontera con la ambulancia. Él conocía bien el punto de cruce fronterizo de El Paso-Ciudad Juárez. Pero, en el camino se perdieron y llegaron al puente de Zaragoza. Al cruzar el puente, un oficial mexicano detuvo la ambulancia. Les preguntó adónde iban. Le dijeron que iban a Jalos. El oficial les dijo que también él era de Jalos. Luego en la aduana encontraron a otro oficial que también era de Jalos. Estos 
paisanos que habían encontrado por coincidencia en la frontera les dieron la facilidad para pasar la ambulancia en la frontera. Don Pancho concluyó este recuerdo de la aventura, diciendo: "Yo estoy seguro de que la Virgen nos ayudó ahí".

Su devoción por la Virgen de la Asunción y su idea de servir a los demás también se reflejan en el oficio que tuvo en la parroquia durante veinte años como encargado del día de los ausentes. Desde 1984, en el siguiente año en que regresó a Jalostotitlán, hasta 2003, cada año, repartía con algunos ausentes programas de las fiestas patronales a los jalostotitlenses que regresaban a su terruño desde distintos puntos de México y de Estados Unidos y los invitaban a la peregrinación del día 16 de agosto.

Otra labor social importante que hizo este ex-migrante después de haber regresado del país del norte fue la organización de la Expo Jalos. En 1984, él y sus amigos organizaron una exposición de obras de seis pintores locales en el patio del edificio de la presidencia municipal, con la idea de exponer a los jalostotitlenses lo que se fabricaba en Jalostotitlán. En 1985, organizó la primera Expo Jalos como un evento organizado por la parroquia de Nuestra Señora de la Asunción y sus feligreses en la Casa Social, en el mismo lugar en donde se organiza este evento de las fiestas de agosto en la actualidad. Anteriormente esta casa era un hotel. Luego, fue donada a la iglesia y funcionó como una escuela de la iglesia. Pero, en el año en que se realizó la primera Expo Jalos en 1985, esta casa estaba prácticamente en desuso y abandonada. Los organizadores de este evento la arreglaron y metieron los productos fabricados localmente, tales como, calzados, muebles incrustados, sillas. Don Pancho asumió el cargo del presidente del comité organizador de la Expo durante muchos años y actualmente participa en el comité organizador como colaborador.

En El libro de los talentos, explicó la virtud cristiana de la caridad que aprendió de su madre desde niño: "Es necesario compartir con los demás, no lo que sobre, sino lo que se tiene. Poco o mucho, de acuerdo a las posibilidades, se debe compartir con los demás". ${ }^{200}$ Esta idea religiosa ha sido el principio que ha

200 Jáuregui Pérez (1981: 81). 
llevado a la práctica de manera coherente a través de su participación en las actividades no lucrativas a beneficio de los demás jalostotitlenses de ambos lados de la frontera. Su historia de vida demuestra el papel que jugó a lo largo de su vida en California y en Jalostotitlán como articulador transnacional entre los ausentes de Estados Unidos y los habitantes de su lugar de origen en varios sentido: contribuyó de manera importante como uno de los fundadores e integrantes del Club Social Jalostotitlán de Los Ángeles al mantenimiento y el fortalecimiento del vínculo tanto entre los paisanos de Estados Unidos como entre los ausentes y su lugar de origen; después de haber regresado a su tierra natal, participó en la práctica religiosa local y los proyectos sociales locales como "enlace" de los ausentes; Su apego a Jalostotitlán y su localismo aportaron a la difusión de la identidad arraigada en Jalostotitlán entre los ausentes de Estados Unidos y entre los habitantes a través de las actividades del club social, su afición por producir los símbolos de su terruño para sus paisanos en Los Ángeles y la organización de la Expo Jalos en su tierra natal. En 1984, inventó la frase "Corazón de los Altos de Jalisco" como el título de Jalostotitlán para promocionar el nombre de su terruño en la región de los Altos y la identidad local entre los habitantes. Hoy en día, la frase "Jalostotitlán en el corazón de los Altos de Jalisco" ha sido apropiada localmente y utilizada en folletos y carteles de las fiestas locales, y de manera similar en la presentación de Xalos Bar en Anaheim.

\section{2) Fundación Jalostotitlán}

El 11 de agosto de 2004, don Antonio González Márquez recibió un reconocimiento como hijo ausente distinguido en la Expo Jalos. Don Antonio nació en 1934 en Jalostotitlán. Nunca pensó en la idea de ir al Norte aunque a principios de los años cincuenta se notaba que había mucha gente de su pueblo que iba a ese país en busca de mejores oportunidades económicas. En 1956, lo convenció para ir a California un amigo que regresó de Estados Unidos. Se fue a Ciudad Juárez con sus amigos del terruño, de ahí cruzó la línea fronteriza con el documento migratorio que había conseguido ahí mismo, y se dirigió a California. Llegando a Los Ángeles, algunos de sus amigos que viajaron con él se fueron a 
Sacramento y a Santa Mónica, otros se quedaron en Los Ángeles. Don Antonio se fue a La Habra, condado de Orange, para ir a la casa de su tío, el único familiar que tenía en Estados Unidos en aquella época.

Durante seis meses trabajó con su tío en la pizca de limones en La Habra. Sin embargo, su primer trabajó en el campo sólo duro meses porque ese año era prácticamente el último año de la cosecha de limones en esas huertas y tumbaron los árboles de limones después de pizcar sus frutos. Al terminar la temporada de cosecha, consiguió un trabajo en el Hotel Biltmore en Los Ángeles, donde trabajaban muchos de sus paisanos de Jalostotitlán. Mientras trabajaba en esta ciudad, buscaba mejores oportunidades de empleo. En 1957, entró a una compañía empacadora de tomate en Fullerton, condado de Orange. En el siguiente año, se casó con doña Teresa en Jalostotitlán. En 1975 entró a una compañía que fabricaba barrenas para hacer pozos de petróleo. Ahí trabajó durante 10 años. En 1985, trabajó durante varios años en una tienda de abarrotes. Posteriormente, trabajó en un hospital del condado de Orange repartiendo medicinas a consultorios. De ese empleo sacó la pensión.

En 1996, obtuvo la ciudadanía estadounidense y dos años después se jubiló. Aunque haya establecido su vida en ese país (compró una casa y todos sus hijos viven en California), ha mantenido el contacto con Jalostotitlán. Durante más de 50 años de su estancia en Estados Unidos, por lo general ha regresado cada año a su tierra natal para asistir a las fiestas locales. Después de haberse jubilado en 1998, va a Jalostotitlán dos o tres veces al año. Cuando no podía regresar a su terruño en agosto, iba a las fiestas de la Virgen de la Asunción que se celebraban en alguna iglesia del sur de California. También ha mantenido relaciones sociales con otros ausentes radicados en California a través de la participación en las actividades del Club Social Jalostotitlán de Los Ángeles en los años sesenta y setenta, en las prácticas religiosas que se dan en torno a la réplica de la imagen de la Virgen de la Asunción, en los eventos sociales y religiosos de familiares y de paisanos y el uso de servicios del supermercados Northgate en la vida cotidiana.

Esta breve presentación de la historia de vida migratoria de don Antonio demuestra que como muchos de otros jalostotitlenses de la misma generación 
radicados en el sur de California, él ha tenido las experiencias de haber vivido en el proceso de transición del campo a la ciudad en trabajo y en lugar de residencia, del mantenimiento del vínculo con su lugar de origen, de la continuidad de las relaciones sociales con sus paisanos y de las prácticas sociales y culturales arraigadas en su terruño. Sin embargo, las experiencias de su vida que han marcado la diferencia con los demás ausentes y han fortalecido aún más su vínculo con Jalostotitlán y con otros ausentes de Estados Unidos comenzaron a finales de los años ochenta.

Conocí a don Antonio en un día de agosto de 2003 en Jalostotitlán cuando yo estaba en la plaza para grabar la peregrinación de la tarde. Empezó a platicar conmigo, y dijo que otro día me había visto en el bar del centro y que a él le llamó mucho la atención la presencia de un japonés en el bar de su tierra natal y estaba sorprendido de que yo estuviera conversando con otros clientes en español. Cuando me encontró en la plaza en ese día, quiso hablar conmigo por curiosidad. Al enterarme de que él fue quien hizo la Fundación Jalostotitlán, cuyo nombre y actividades yo había escuchado del director de la Casa de la Cultura anteriormente, me surgió la curiosidad por él. Desde entonces, tuve la oportunidad para entrevistarme con él acerca de la Fundación Jalostotitlán en su lugar de origen durante las fiestas de agosto del mismo año y de otros, en California cuando fui a hacer el trabajo de campo y en la Ciudad de México cuando vino a México con su esposa y la familia de uno de sus hijos.

La idea de organizar la Fundación Jalostotitlán le surgió cuando estaba trabajando por la noche en una tienda de abarrotes en 1988. Pensó que ya pronto iba a llegar la navidad, pero no se había realizado ninguna ayuda a las familias de escasos recursos de su tierra natal durante varios años desde que habían terminado las actividades del Club Social Jalostotitlán de Los Ángeles, y que sería necesario crear alguna organización que cubriera la función de dar apoyos sociales a beneficio de su lugar de origen, misma que había tenido este club de los migrantes jalostotitlenses. Posteriormente, habló por teléfono con sus paisanos sobre su idea de crear una fundación con donaciones voluntarias de dos veces al año por parte de los jalostotitlenses radicados en Estados Unidos para ayudar a la 
gente más necesitada de Jalostotitlán. Varios de sus paisanos estaban de acuerdos con esta idea y le dieron donaciones de tres dólares hasta 200 dólares. Así comenzó con las actividades de la Fundación Jalostotitlán.

En 1989, para formalizar las actividades de recaudación de fondos por parte de los ausentes en Estados Unidos y de entrega de ayudas económicas y materiales a los beneficiarios de Jalostotitlán, registró esta nueva organización en California con el nombre de Jalostotitlan Foundation como una organización no lucrativa.

Aunque don Antonio no tuvo ninguna preparación profesional de administración sobre este tipo de organización en alguna institución, los conocimientos y las experiencias que adquirió a través de la participación en las actividades del Club Social Jalostotitlán de Los Ángeles le permitieron manejar la fundación y realizar distintos tipos de trámites sin dificultad. Cuando existió este club de los migrantes en los años sesenta y setenta, él fue miembro de la mesa directiva del club y una vez asumió el cargo de presidente.

Una de las diferencias importantes que tiene la Fundación Jalostotitlán con el Club Social Jalostotitlán de Los Ángeles es que algunos habitantes de Jalostotitlán se integraron en la fundación como voluntarios. Ellos tienen la función de investigar quiénes son la "gente menos beneficiada" de la localidad que no puede recurrir a otras personas ni instituciones para pedir ayuda, por lo tanto, son más necesitada que otros jalostotitlenses. Esta idea de contar con agentes de "enlace" de la fundación le surgió de una reflexión que tuvo don Antonio sobre las experiencias previas en las actividades del club social. Cuando este club de migrantes entregaba a despensas a los habitantes de Jalostotitlán, primero, les dada cupones para cambiarlos por despensas. Pero, posteriormente, los integrantes del club se dieron cuenta de que entre la multitud de personas que fueron a recibir cupones había personas que tenían tanto dinero que no necesitaban la ayuda material de alguna parte. Don Antonio considera a los voluntarios como "ojos" de la fundación y que sus labores son fundamentales para que pudiera entregar despensas y otro tipo de ayuda directamente a las personas más necesitadas y menos beneficiadas que otro. 
Los voluntarios han buscado a la gente menos beneficiada entre cinco categorías de habitantes de Jalostotitlán a quienes la fundación otorga apoyos económicos y materiales: ancianos que viven solos y prácticamente abandonados; las familias de escasos recursos económicos; niños enfermos o con capacidades diferentes que no reciben apoyos económicos ni atención médica de otras instituciones; estudiantes de escasos recursos económicos, y por último, jóvenes que se dedican al deporte.

En el último día de mi estancia en Jalostotitlán en agosto de 2003, cuando yo estaba hablando con don Antonio, hice un comentario de que no había visto la pobreza en Jalostotitlán y que Jalos era un lugar relativamente rico por el dinero que traían y enviaban los migrantes. Este comentario parecía que le había molestado y me preguntó si yo tenía tiempo para conocer otra realidad de Jalostotitlán. Tomamos un taxi para que yo pudiera hacer una visita a las casas de algunos beneficiarios de la fundación antes de la hora de mi partida en autobús. Primero, conocí a una señora que vivía con cuatro niños en una casa hecha de madera con el techo de lámina. Ella cocinaba anteriormente fuera de su casa con leña. La fundación le otorgó a ella en ese año una estufa de gas. La segunda casa que visité fue una casa excavada en la barranca donde vivía una pareja de tercera edad. Su principal fuente de ingreso era la venta de chicles y dulces en la mesa colocada en la entrada de su casa. Por último, visitamos a la familia de un hombre de mediana edad que trabajaba como albañil y jardinero. Me comentó que la situación económica de su familia era muy difícil, dado que en la temporada de Iluvia, no había trabajo y que aunque hubiera querido ir a Estados Unidos, no tenía parientes en Estados Unidos con quien mantuviera comunicación estrecha, y además era difícil emigrar a Estados Unidos con su esposa y dos hijos.

Las familias que conocí durante el recorrido de ese día vivían en las orillas de la cabecera municipal. Durante el trabajo de campo que hice en ese verano, nunca había visitado esta parte de la ciudad. Durante las entrevistas con estas personas, me sentía tan alejado del centro de la ciudad en donde yo había realizado la observación, la grabación de las escenas de las fiestas y entrevistas con los ausentes y había frecuentado el bar y la cantina. Al mismo tiempo, me sentía 
avergonzado del comentario que le hice a don Antonio antes de comenzar este recorrido y de mi ignorancia. Cuando le dije a don Antonio que yo no había conocido ni había imaginado este aspecto de la realidad de Jalostotitlán, me dijo que no sólo era yo, sino muchas personas que vivían en el centro y los ausentes también desconocían la vida de la gente menos favorecida de esta ciudad; en el centro no se veía la pobreza porque los que no tenían dinero casi no iban al centro durante las fiestas para evitar la tentación de gastar dinero; los ausentes por lo general iban al centro, por lo tanto, no podían saber que en las orillas de la ciudad había otra realidad de su tierra natal.

En otra ocasión cuando estuve hospedando en su casa ubicada en Brea, en el condado de Orange, me comentó que cuando él enviaba boletines de la Fundación Jalos a los ausentes, había un amigo que no creía que hubiera pobreza en su terruño. Tras la explicación de don Antonio, entendió la necesidad de la donación por parte de los ausentes para ayudar a la gente menos beneficiada de su lugar de origen y le envió un cheque de 50 dólares.

Según don Antonio, en las décadas anteriores en que los migrantes de la misma generación salieron a Estados Unidos, había mucha pobreza en Jalostotitlán. Esta realidad era el principal motivo de ir al Norte para muchos jalostotitlenses. Hoy en día, para la mayoría de los habitantes, la condición de vida ha mejorado bastante por la urbanización y por las remesas de los migrantes. Pero sigue siendo difícil para un pequeño sector de la población que no encuentra alguna solución dentro de la localidad ni puede insertarse en el proceso migratorio. El problema de la situación actual es que la diferencia entre las personas que tienen dinero y los pobres se ha ampliado y que la gente menos favorecida del mejoramiento de condición de vida en Jalostotitlán se ha vuelto más invisible. Por ejemplo, en el caso de aquellos ancianos que no habían ocupado algún trabajo del cual pudieran sacar la pensión ni tienen hijos que les envíen regularmente remesas desde Estados Unidos y que vivan cerca para cuidarlos, la marginación es tan extrema que no tienen suficientes recursos económicos para cubrir los gastos de alimentos, e incluso ha habido algunos casos en que se mueren solos sin que nadie se diera cuenta. Por eso, don Antonio insiste en la importancia de la 
función de la fundación que hace visible a la gente menos beneficiada ante los demás jalostotitlenses.

Durante la primera década, don Antonio realizaba labores de la fundación en Jalostotitlán de manera secreta sin hacerla pública ante los habitantes porque la fundación aún no tenía tantos recursos como para repartirlos entre muchas personas y porque quiso evitar el problema de no poder ayudar a personas menos beneficiadas y más necesitadas que otras al convocar a demasiada gente. Por eso, hasta que don Antonio decidió participar en la Expo Jalos a principios de este siglo, la Fundación Jalostotitlán no era conocida por la mayoría de los habitantes. En agosto de 2003, la fundación tuvo un espacio de exposición en un salón de la Casa Social. Había algunas razones de su participación: entregar reconocimiento a los voluntarios que colaboraron con las labores de la fundación durante 15 años desde su inicio; conocer a más ausentes radicados en distintos lugares de Estados Unidos, y transmitir tanto a los habitantes como a los ausentes otra realidad de Jalostotitlán para hacer más visible a la gente menos beneficiada que ha sido invisible y olvidada en el proceso del desarrollo local por medio de la urbanización y la migración.

Don Antonio puso en las mesas del salón boletines de la Fundación Jalostotitlán, cartas de agradecimientos de parte de algunos beneficiarios, fotos de voluntarios, reconocimientos que iba a entregar a los voluntarios, artículos deportivos, un tanque de oxígeno y otros tipos de ayudas materiales que iba a entregar a los beneficiarios, fotos y carteles del Club Social Jalostotitlán de Los Ángeles, etc. Atendía a los visitantes de la exposición para explicarles la información general de la fundación y les repartía formatos de registro de donantes.

Al finalizar la Expo Jalos, me comentó que pudo tener un logro importante para la fundación a través de su participación en la Expo porque pudo conocer a muchos ausentes interesados en las actividades de la fundación con quienes no había podido tener contacto en Estados Unidos. Aunque don Antonio realizaba la difusión de la información de la fundación en Estados Unidos, no era fácil contactar con aquellos ausentes que vivían de manera dispersa y separada en 
distintas localidades y condados de California y de otros estados de ese país. En este sentido, la participación en la Expo Jalos fue una selección de momento y lugar justo para conocer a más ausentes porque durante las fiestas de agosto Jalostotitlán se convierte en un lugar de encuentro de los ausentes que vienen de distintos puntos de la Unión Americana y la Casa Social es uno de los sitios que atraen a los visitantes. Esta estrategia de crear desde el otro lado de la frontera un nuevo vínculo con los ausentes radicados en Estados Unidos, a quienes es difícil de conocer viviendo en ese país, tuvo un efecto positivo inesperado para don Antonio. Durante la participación en la Expo, fue entrevistado por una periodista del condado de Orange. El 15 de agosto de 2003, se publicó un artículo sobre la Fundación Jalostotitlán en un periódico del condado de Orange, California. En ese mismo día, cuatro estadounidenses hablaron a su casa ubicada en el mismo condado para hacer donaciones a la fundación. Don Antonio recibió esa noticia aún estando en Jalostotitlán.

El 11 de agosto del siguiente año, recibió el reconocimiento como hijo ausente por sus contribuciones a su lugar de origen a través de sus labores de la Fundación Jalostotitlán. Desde el inicio de la fundación se había dedicado a labores de la fundación en su tiempo de ocio. Cuando trabajaba durante más de ocho horas antes de la jubilación, dedicaba algunas horas que sobraban después de trabajo y los fines de semana a labores de la fundación. Después de la jubilación, se metía en el trabajo de medio tiempo meses antes de la navidad y las fiestas de agosto para juntar dinero suficiente para cubrir sus gastos de viaje a Jalostotitlán. En la entrevista realizada con él en el otoño de 2004 en el garage de su casa que había arreglado para poner la oficina de la fundación, me explicó que se dedicaba al servicio voluntario para su tierra natal en el tiempo de ocio porque después de trabajo y de la jubilación, no tenía tantas cosas que hacer como en Jalostotitlán y porque le daba una satisfacción enorme ver la alegría de los beneficiarios al entregarles ayudas económicas y materiales que preparó con donaciones de sus paisanos. El día de la entrega del reconocimiento en la Expo Jalos 2004, estos esfuerzos de varios años y la colaboración de los demás 
ausentes y los voluntarios de Jalostotitlán fueron reconocidos en su tierra natal. Para él, ese día fue uno de los momentos más felices de su vida.

En este apartado, he presentado dos personajes de Jalostotitlán que han vivido en el proceso migratorio y han tenido actividades que crean y mantienen, a beneficio de su tierra natal, el vínculo transnacional entre los ausentes de Estados Unidos y su lugar de origen. La historia de vida del primer personaje demuestra el papel que jugó durante y después de su vida migratoria como articulador de la población desplazada a California con Jalostotitlán. Como migrante, se dedicó a la organización del Club Social Jalostotitlán de Los Ángeles que contribuyó de manera importante para el mantenimiento del sentido de pertenencia al lugar de origen y las relaciones sociales entre los paisanos y para la creación del vínculo con Jalostotitlán por medio del envío de ayudas materiales para el desarrollo local. Como habitante retornado, jugó el papel de "enlace" de los ausentes en la donación de las ambulancias y en la práctica religiosa y fue uno de los fundadores de la Expo Jalos, un evento de las fiestas de agosto que busca promocionar su tierra natal tanto entre los habitantes como entre los ausentes.

El segundo personaje también ha contribuido a ayudas sociales como articulador entre los ausentes y el lugar de origen por medio de la creación del vínculo transnacional que canaliza donaciones de los ausentes a Jalostotitlán después de la desaparición de las actividades del Club Social Jalostotitlán de Los Ángeles. A diferencia del club social, la Fundación Jalostotitlán no sólo facilita canalizar ayudas materiales y económicas hacia la localidad de origen, sino que también se dirige de manera directa al sector más necesitado de la población, lo cual ha sido posible gracias a la existencia en Jalostotitlán de los voluntarios como enlaces de la fundación que se encuentra en California. Otro punto que se destaca de este personaje es que en el contexto socioeconómico actual de Jalostotitlán en que la pobreza se ha vuelto más invisible que antes, presenta esta realidad a los ausentes durantes las fiestas locales, en las cuales Jalostotitlán les presenta las imágenes lúdicas del lugar, para hacer visible el sector menos beneficiado de la población ante las miradas de los ausentes. Para la fundación, las fiestas son un 
momento oportuno para difundir esta imagen del terruño no idealizada entre la población desplazada a Estados Unidos, dado que durante estos tiempos rituales Jalostotitlán se convierte en un lugar de encuentro y de convergencia de múltiples miradas de los ausentes.

La entrega del reconocimiento a estos dos personajes por parte del comité organizador de la Expo Jalos representa la flexibilidad de la sociedad local en la definición de la forma de ser jalostotitlense y de pertenecer a Jalostotitlán. En esta ceremonia, el nacimiento en la localidad y la residencia en ella son requisitos para ser "hijo de Jalos". Pero, como existen otras dos categorías de jalostotitlenses, el lugar de nacimiento y el lugar de residencia son requisitos relativos para ser jalostotitlense. Hijo ausente es la categoría de jalostotitlenses que son originarios de esta localidad pero cuya residencia actual se encuentra en otros lugares. Hijo adoptivo es la categoría de habitantes de Jalostotitlán que nacieron en otros lugares. Sin embargo, lo que se flexibiliza para entregar el reconocimiento no es solamente la categoría de ciudadanía de Jalostotitlán, sino también la forma de relacionarse con esta localidad. En el caso de don Antonio quien fue seleccionado como hijo ausente distinguido, a pesar de su ausencia física durante décadas como residente en esta localidad, su particular forma de estar presente en la vida local y contribuir al bienestar de la localidad a través de las actividades de la fundación fue reconocida. En el caso de la entrega del reconocimiento a don Pancho, se observa una interpretación flexiva del sujeto local. A pesar de ser seleccionado como hijo de Jalos distinguido, su forma de contribuir a la vida local no se limitó dentro del marco territorial de la localidad. Primero siendo ausente, y posteriormente siendo habitante de Jalostotitlán, este personaje ha participado en la vida local a través del vínculo con aquellos jalostotitlenses que viven fuera de su localidad de origen. Lo que significa la entrega del reconocimiento a este personaje es la aceptación social de esta forma tan particular de ser lugareño, una forma de ser actor local pero cuyas actividades y prácticas han sido más transnacionales que locales. En suma, la entrega del reconocimiento de jalostotitlenses distiguidos en la Expo Jalos es una ceremonia, donde se redefine y se representa la noción de ciudadanía incluyente que reconoce varias formas de 
ser jalostotitlense y de pertenecer a esta localidad, y refleja la conciencia de una sociedad civil local que vive en el contexto transnacional.

\section{CONSTRUCCIÓN DE LA NOSTALGIA COLECTIVA A TRAVÉS DE LOS TEXTOS}

En los años recientes, durante las fiestas de agosto, se ha realizado la presentación de varios libros sobre Jalostotitlán por escritores, cronistas, arquitecto e historiador originarios de esta localidad. Las editoriales cuyos propietarios también son originarios de esta localidad han preparado la publicación de nuevos libros para poder realizar la presentación de obras para las fiestas de agosto, debido a que esta temporada es el período en que se encuentran en la localidad los ausentes que son los principales consumidores y lectores de libros sobre Jalostotitlán.

Sin embargo, el interés de los ausentes en los libros sobre su terruño ha existido desde ya hace tres décadas. El libro titulado En un Pueblo Alteño escrito por Pedro Rodríguez Lomelí, originario de Jalostotitlán radicado en Guadalajara, primero fue publicado en 1966 cuando el autor tenía 67 años. En esta ocasión, apenas se imprimieron 200 ejemplares y se repartieron entre sus amigos y algunos paisanos. Se trataba de un libro de ensayos sobre los recuerdos de su infancia, su pueblo natal, sus padres, su gente, costumbres y paisaje de su tierra natal, narrados con un fuerte tono de añoranza. La nueva edición de este libro fue publicado en 1976 por indicaciones del Club Social Jalostotitlán de Los Ángeles que tomó un gran interés en el texto. El autor explica en el preámbulo del texto de la nueva edición que los ausentes radicados en Estados Unidos y él comparten un fuerte apego a su tierra natal:

Ellos y yo estamos de acuerdo en un aspecto: en amar entrañablemente a nuestra querida tierra, nuestro pueblo inolvidable: Jalostotitlán, del Estado de Jalisco, en la famosa Región de Los Altos.

Mi libro "EN UN PUEBLO ALTEÑO", trata de ser un homenaje a ese pueblo nuestro, que más amamos mientras más lejos estamos de él. Sentimos la nostalgia de su paisaje, de su fisonomía, de su clima, de sus torres de sus templos, de la escuela en donde aprendimos las primeras letras, de nuestras correrías por sus campos, de nuestras travesuras de pequeños y de nuestra madre que las soportó con 
tanta paciencia y cariño para nosotros; y recordamos a nuestros seres queridos, muchos de ellos enterrados en su viejo camposanto. Y desde nuestra lejanía estamos en espíritu en todos y cada uno de los rincones de Jalos, y mentalmente convivimos allá con todos nuestros paisanos y nuestros parientes que allá quedaron, mientras la vida nos arrastró a nosotros lejos de ese bendito lugar."

Por eso comprendo a los integrantes del "CLUB SOCIAL JALOSTOTITLÄN", de Los Angeles, Cal., al querer leer un libro que habla de nuestro terruño; y a todos los jalosotitlenses que radican en el extranjero y que siguen amando a Jalos. Para todos ellos va mi saludo de paisano; y junto al de ellos, mi amor por nuestro pueblo. ${ }^{201}$

Lo que implica este libro es que desde hace tres décadas, la nostalgia ha sido uno de los temas principales de los textos escritos por los jalostotitlenses y al mismo tiempo, es un tema en que prestaban los ausentes radicados en Estados Unidos un fuerte interés.

En 1981, se publicó el libro titulado El libro de los talentos, del cual cité varias narrativas sobre la nostalgia de los migrantes hacia Jalostotitlán en el capítulo 2. Es un libro que se compone de más de 120 entrevistas con los migrantes, principalmente de los migrantes jalostotitlenses, que vivían en más de 40 lugares diferentes de Estados Unidos y México y con una docena de los jalostotitlenses radicados en Jalostotitlán que habían tenido experiencia migratoria. A finales de los años setenta, se formó un pequeño grupo bíblico de los migrantes jalostotitlenses en Los Ángeles. Cada semana los integrantes se reunían durante dos horas en una iglesia católica de la misma ciudad. Don Severiano Jáuregui Pérez, les contó a sus compañeros del grupo con entusiasmo su proyecto de hacer un libro sobre los migrantes y los convenció para que colaboraran en este proyecto. Ellos formaron un grupo editorial que se llamaba "Difusora Cultural Los Talentos". Sus compañeros financiaron la investigación que realizó don Severiano en distintos lugares de Estados Unidos y México para recolectar las entrevistas y la publicación del libro. Imprimieron 5,000 ejemplares y organizaron la presentación del libro en La Barca, Jalisco.

Don Severiano Jáuregui Pérez explica el objetivo del texto en la introducción: "Nuestro sueño es encender estrellas y avivar esperanzas, en los ánimos deprimidos de muchos de nosotros que hemos llegado desde lejanas tierras." ${ }^{202}$

201 “Preámbulo" del libro (Rodríguez Lomelí, 1976).

202 Jáuregui Pérez (1981: 10). 
Hay tres tipos de narrativa de los migrantes que recolectó don Severiano durante su investigación. El primer tipo de narrativa es en la que se expresan el desacuerdo con la discriminación en contra de los inmigrantes mexicanos que existía en Estados Unidos y el reclamo del reconocimiento social de los migrantes en la sociedad estadounidense y de un trato más justo para los migrantes que contribuían al desarrollo económico de ese país. El segundo tipo de narrativa es de aquellos migrantes y sus descendientes que hicieron logros destacables en sus actividades económicas como trabajadores o empresarios y en sus actividades intelectuales en las escuelas y en sus carreras profesionales a pesar de las dificultades con las que se enfrentaban en sus vidas como minoría étnica en la sociedad estadounidense. A través de sus historias de éxito, varios migrantes narran la importancia de seguir con la idea de progreso y superación personal. A pesar de que hay narrativas del éxito de los migrantes que demostraron sus logros económicos e intelectuales y realizaron sus sueños americanos, las narrativas de la nostalgia les surgen como consecuencias de la separación temporal y espacial de su tierra natal, el contraste de la vida y la discriminación que experimentaban en Estados Unidos. Son el tercer tipo de narrativa de los migrantes que se presenta en este libro. En este sentido, para muchos de los migrantes que fueron entrevistados, su proyecto de retorno y sus recuerdos de la tierra natal son también lo que alivia la esperanza y levanta los ánimos deprimidos de los migrantes.

Hay dos puntos que se destacan acerca de este libro. En primer lugar, es un libro sobre los migrantes, escrito, publicado y financiado por los migrantes. Además, los lectores principales del texto eran los migrantes, dado que por el contenido del texto, quienes prestaron más interés en comprar el libro fueron los migrantes. En segundo lugar, la publicación del libro era un medio para transmitir las voces vívidas de los migrantes sobre sus vidas, sus dificultades y sus esperanzas a sus paisanos y para buscar el reconocimiento de su presencia, principalmente, en el país receptor.

Este movimiento literario de los jalostotitlenses y el interés de los ausentes radicados en Estados Unidos en los textos sobre Jalostotitlán aún siguen vigentes 
hasta el presente. Aquí, quiero presentar algunos libros y una revista publicados localmente pero difundidos más allá de la frontera del norte de México, en los cuales la nostalgia aparece como uno de los temas importantes. Lo que se destaca en estos textos, la nostalgia no se presenta como un sentimiento deprimido que se estanca y se detiene en recuerdos del pasado, sino como una forma de crítica al presente y como un sentimiento inspirador o una motivación para cambiar el presente y para imaginar el futuro.

1) La nostalgia y la añoranza son "mejores armas" para enfrentar el presente y el futuro

En 2003 se publicó la nueva edición del libro La Querencia, del cual cité en el capítulo 2 algunas narrativas nostálgicas sobre su tierra natal y los recuerdos de su infancia de la autora Guadalupe Gutiérrez de Mantecón. En las prosas que elaboró durante su vejez en la Ciudad de México, la autora trató de reconstruir su tierra natal y mantener vivos a sus seres queridos a través de sus recuerdos y expresó su nostalgia hacia su tierra natal, el estilo de vida rural y sus seres queridos, de los cuales el tiempo y el espacio la separaron. José Atanasio Gutiérrez y Gutiérrez, un migrante jubilado originario de Jalostotitlán radicado en la Ciudad de México, aportó al libro un breve ensayo de presentación de la autora y su obra. Sostiene que las narrativas nostálgicas de la autora tienen un significado importante para aquellas generaciones que pasaron alguna parte de su vida en los pueblos y ranchos de los Altos de Jalisco y que están observando, con temor y preocupación, cómo los valores tradicionales y el estilo de vida rural han sido relegados y reemplazados por nuevas ideas y las influencias de la vida moderna, sobre todo, entre las nuevas generaciones:

Más aún, podría yo decir que este libro refleja de manera muy acabada un estilo de vida antiguo que se extendió y aún perdura parcialmente en la región de los Altos de Jalisco; me refiero a la suma de costumbre y tradiciones que practicaban nuestros abuelos [...] se describe con gran fidelidad el tipo de vida que llevaron nuestros padres y abuelos, dentro de un ambiente campesino de principios del siglo veinte. Quienes, siendo niños, alcanzamos a vivir en algún rancho de Los Altos [...] podemos constatarlo en la lectura de La Querencia [...] 
[...]Por desgracia, la historia del país, de cincuenta años a esta parte, nos ha permitido ser testigos de cómo estas formas antiguas de vida son de repente distorsionadas y aún barridas por una especie de huracán que quisiera llevarse estilos de existencia consagrados por muchas generaciones de mexicanos.

Pero de cara a cara a esta frustración [...] no pensamos -ni por equivocaciónque todo tiempo pasado fue mejor; sabemos muy bien que la vida moderna ha traído, aunque no para todos, múltiples beneficios y comodidades de que carecieron las generaciones pasadas; pero, a cambio, los costos en varios sentidos han sido enormes, fundamentalmente en los ámbitos familiares y sociales, como a diario lo seguimos lamentando.

[...], y todo hace pensar que los jóvenes de hoy se mueven, en la vida, orientados por otros valores y llevados por impulsos y objetivos distintos a los que tuvieron nuestros padres y abuelos. Puede esto obedecer a cambios profundos que han dislocado las relaciones sociales y familiares [...]

[...] tenemos la confianza de que la lectura de este libro servirá para confirmarnos en los valores que todavía nos quedan, fundamentalmente a la hora de enfrentar los retos de la vida moderna; y confirmamos que sus reflexiones nos podrán ayudar a encarar mejor un futuro todavía más difícil.

[...] En fin, mi más profundo deseo es que el lector de La Querencia recupere la fuerza y virtud alteñas que encierra el libro con abundancia, para tonificar su mente y corazón, disponiendo así de mejores armas, por así decirlo, para enfrentar con éxito los días actuales y venideros...203

A pesar de que aquel mundo rural y estilo de vida tradicional, que muchos de los jalostotitlenses vivieron en alguna etapa de su vida como la autora, ahora se destinan a la desaparición y la alteración por las influencias de la vida moderna y por los cambios generacionales, José Atanasio considera que las narrativas nostálgicas de la autora le da al lector la oportunidad para conocer una forma de vida que existía antes y que fue valorada durante generaciones y para reflexionar sobre la importancia de la conservación de los valores tradicionales que aún quedan en su terruño, y le permite retornar a la tierra perdida a través de las memorias y la imaginación para tener más fuerza y motivación para vivir el presente y el futuro. En este sentido, como dice él, para las generaciones que están en la etapa de vejez del ciclo de vida y viven la vida presente observando la desaparición y la alteración de los valores tradicionales, el apego al pasado y a las tradiciones y la añoranza por el terruño son "mejores armas" para enfrentar el presente y el futuro.

203 José Atanasio Gutiérrez y Gutiérrez (2003: 8, 12, 13, 14). 


\section{2) "Guía de emociones"}

El 9 de agosto de 2003 hubo la presentación del libro titulado Viaje al corazón de los Altos en la Casa de la Cultura de Jalostotitlán. ${ }^{204}$ En este libro, dos ausentes jalostotitlenses, José Atanasio Gutiérrez y Gutiérrez, un migrante jubilado radicado en la Ciudad de México, y Sergio Gutiérrez, un joven ausente radicado en California, reconstruyen el paisaje de Jalostotitlán en donde identifican su fuerte apego emocional y sus recuerdos en dos formas de expresión artísticas diferentes: a través de sus fotografías, Sergio demuestra el interés en su lugar de origen fiel al estilo de vida tradicional, a la religiosidad y al campo; por su parte, José Atanasio expresa su apego a Jalostotitlán, a su gente, al estilo de vida tradicional arraigado en la fuerte religiosidad y al paisaje rústico a través de sus poemas. Con la combinación de textos e imágenes fotográficas, estos dos ausentes de diferentes generaciones y de diferentes lugares de residencia invitan al lector a un viaje de memorias, imaginación y emociones al corazón de los Altos de Jalisco para conocer su arquitectura tradicional, su gente, los pueblos de su alrededor y ex-haciendas que ellos consideran como aspectos que forman parte importante de la identidad jalostotitlense.

Durante la presentación del libro, dieron comentarios tres personajes que habían participado en la publicación de este libro: Alfredo Gutiérrez, José Atanasio Gutiérrez y Sergio Gutiérrez. Este libro es una obra que hicieron los Gutiérrez de diferentes generaciones que viven fuera de Jalostotitlán. Alfredo, un ausente radicado en Guadalajara, quien colaboró con la publicación del libro como editor, comentó que lo que trataban de hacer a través de la publicación de este libro fue compartir la emoción personal hacia Jalostotitlán con los demás a través de lo poético y lo estético y ofrecer al lector un libro que le sirviera en su búsqueda de la esencia y la identidad.

José Atanasio explicó que los poemas y las fotografías del libro evocaban las imágenes de Jalostotitlán de la época en que él vivió y salió de ahí y representaban sus recuerdos de la vida en su tierra natal y sus sentimientos hacia

${ }^{204}$ Atanasio Gutiérrez y Sergio Gutiérrez, 2003, Viaje al corazón de los Altos, México, Acento Editores. 
Jalostotitlán. Comentó que esperaba que este libro le sirviera al lector que vivía lejos de Jalostotitlán para facilitar su regreso imaginario a la tierra natal y mantener vivo en su mente el paisaje de su terruño:

Aquí nacimos y probablemente volveremos aquí [...] Estamos tan arraigados como muchos de ustedes que tampoco viven aquí, pero año con año, por lo menos en estas fechas, probablemente en otras en principios del año y durante el carnaval, estamos cada vez y cada vez insistentemente. Lo que quisiéramos es recuperar mucho de lo que aquí hemos sentido y mucho de lo que hemos vivido [...] condición de emigrantes que somos la mayoría en términos de porcentaje y numérico de este pueblo. Este pueblo está hecho de gentes que se han salido. Van y vienen, van y vienen siguen saliendo a otros países actualmente [...] Justamente esto es lo que he querido hacer con estos textos [...] que reflejan muy bien esta nostalgia que uno siente cuando se aleja de aquí, nostalgia por el pueblo [...] vacío por nuestros familiares que dejamos aquí, por tantas cosas y tantas vivencias que aquí se quedan [...] Esperamos que sobre todo para los que estamos lejos, cada vez que sentimos un poco de nostalgia, tomemos el libro, lo hojeemos y sintamos que otra vez nos vuelve la fuerza que en algún momento puede estar faltando para seguir nuestro trabajo y nuestra vida común y corriente. ${ }^{205}$

Sergio explicó que la fotografía presentada en la portada del libro de un niño trepando a un mezquite en el rancho de sus antepasados le hizo recordar sus travesías que hacía él en su niñez en Jalostotitlán, y que este efecto de las imágenes evocadoras de los recuerdos y los sentimientos hacia su tierra natal era precisamente lo que caracterizaba a este libro. A simple vista, el libro parece ser una guía turística. Pero, para él, es "una guía de emociones", una guía que lleva al lector al fondo de sus recuerdos. Lo que deseaba era que el lector encontrara en el libro un poema y una foto que lo llevaran a sus recuerdos e hicieran recordar su niñez y su presente y quizá imaginar su futuro y que la lectura del libro lo llevara a un paseo a la fuente de sus emociones.

En suma, es un libro elaborado por el trabajo colectivo de tres ausentes de diferentes generaciones y radicados en diferentes ciudades para transmitir sus nostalgias hacia su tierra natal y sus terruños imaginarios a los demás jalostotitlenses que también viven fuera de su lugar de origen como ausentes a través de las imágenes que les evocan sus recuerdos y sentimientos. En este

${ }^{205}$ Comentario que hizo el poeta en la presentación del libro en la Casa de la Cultura de Jalostotitlán el 9 de agosto de 2003. 
sentido, la publicación de este libro es una práctica cultural que busca crear y fortalecer entre los ausentes el vínculo emocional con su lugar de origen, a través del ensamblaje de un objeto cultural hecho de las imágenes del terruño, a pesar de las diferencias generacionales y de condiciones y experiencias de la vida cotidiana en distintos lugares de residencia.

\section{3) Arquitectura como "depósito" de memoria colectiva}

Tres años antes de la publicación de este libro, Alfredo Gutiérrez hizo un libro sobre los estilos arquitectónicos de siglos anteriores en Jalostotitlán para la celebración de las fiestas de agosto de 2000. La presentación de su obra se realizó en el festival de los ausentes que tuvo lugar en la Casa de la Cultura el 16 de agosto, el día de los ausentes del mismo año. En este libro titulado Xalostotitlán en Imágenes, Alfredo, quien se dedica a la arquitectura en Guadalajara, le invita al lector a hacer un recorrido imaginario del paisaje arquitectónico tradicional de su tierra natal a través de la descripción de los estilos arquitectónicos de siglos pasados y las imágenes fotográficas antiguas de la ciudad. ${ }^{206}$ El libro comienza con una narrativa de los sentimientos encontrados del autor como ausente: el fanático apego a su tierra natal y el deseo de retornar a su lugar de origen.

Entre todas las ciudades de la Tierra que podríamos visitar, sin duda hay muchas que nos impresionarían por su belleza o por su extensión, por su modernidad o bien por su antigüedad. Pero sólo hay una que, sin ningún atributo de los anteriores, no podríamos olvidar jamás y esa es la ciudad de nuestro nacimiento, la que albergó nuestros primeros años de vida, por lo común, los que consideramos más felices.

Hay quienes todo el tiempo han habitado en esa ciudad y quienes habiéndola dejado un día, nunca más volvieron. Pero aún los más ausentes aprenden, ya sea al final de su existencia o antes, que todos los caminos, más aún los de la vida y la memoria, tienen dos sentidos, y uno de ellos nos conduce de regreso al lugar de origen, donde yace el cordón umbilical o el instante remoto del primer amor. ${ }^{207}$

En la mayor parte de las páginas del libro, el autor describe el paisaje arquitectónico de Jalostotitlán y el estilo de vida de los siglos anteriores, tales como, ex-haciendas, el estilo de vida rural, el templo parroquial, el santuario, la

${ }^{206}$ Alfredo Gutiérrez R., 2000, Xalostotitlán en Imágenes, Guadalajara, Acento Editores y Amate editorial

${ }^{207}$ Gutiérrez R. (2000: 11, 12). 
capilla, casas del estilo colonial, principales calles y edificios históricos de la ciudad, la celebración de las fiestas de agosto de décadas anteriores del siglo XX, el cambio en el paisaje de Jalostotitlán por la urbanización y por la modernidad. Regresando del recorrido del pasado a la actualidad, en la conclusión del libro, el tono romántico de sus narrativas sobre su tierra natal se desvanece, en cambio, expresa un dilema al contemplar la realidad del presente en que estos patrimonios arquitectónicos y el paisaje de la ciudad se encuentran en la difícil situación de mantenerse como antes.

El centro es al mismo tiempo la parte que más modificaciones ha sufrido [...] Las casas particulares no se han librado de ser sustituidas por fincas acopladas a los usos modernos, principalmente el comercial debido al reajuste del interés de sus propietarios

Es cierto que la ciudad no puede mantenerse aletargada y que los inmuebles deben adaptare a la vida de la gente que los utiliza, como también es cierto que no puede perderse en la vorágine del momento actual toda la historia que radica en su arquitectura, pues esta es como un libro donde podemos darnos cuenta de lo que fue la vida de las personas en diferentes épocas. Todos los estilos arquitectónicos reflejan la vida del ser humano que los utilizó. ${ }^{208}$

Al cerrar el texto, en el último apartado, Alfredo convierte la nostalgia hacia el pasado en un motivo para cambiar la situación actual de su terruño y en una visión o una esperanza para el futuro, en vez de estancar su narrativa en el pesimismo y en las miradas deprimidas que se dirigen al pasado.

Mi deseo es que junto con el placer experimentado en la contemplación de estas imágenes, surja la reflexión acerca de la responsabilidad que todos tenemos, si no de recuperar lo ya perdido, al menos de conservar lo que aún nos queda. Nuestro Jalos aún tiene sitios hermosos a pesar de la urbanización y la ignorancia. Ojalá que el próximo milenio la inteligencia se anteponga a la miopía en cada uno de nosotros, para que antes de alterar nuestro - entorno histórico lo pensemos dos y hasta tres veces, y así las generaciones venideras tengan algo que apreciar. ${ }^{209}$

En suma, lo que intenta el autor a través de un paseo imaginario al pasado con las narrativas nostálgicas de un ausente es crear entre los demás jalostotitlenses una memoria colectiva y despertar en ellos la conciencia de conservación del paisaje

${ }^{208}$ Gutiérrez R. (2000: 96).

209 Gutiérrez R. (2000: 96) 
arquitectónico de Jalostotitlán en donde las casas del estilo colonial y otros edificios históricos aún se quedan como "depósitos" de memoria colectiva sobre sus antepasados, el estilo de vida tradicional y la historia local.

\section{4) Casonas tradicionales como patrimonio cultural}

Esta intención de despertar en el lector la conciencia de conservación del patrimonio cultural de Jalostotitlán a través de las narrativas nostálgicas sobre el pasado y las imágenes fotográficas también es compartida por el cronista de Jalostotitlán, Luis Jesús Ramírez Jiménez, el autor del libro titulado Casonas del Pasado en el Corazón de los Altos, publicado en 2002 por una editorial que administra el mismo cronista. ${ }^{210}$ En este libro, el autor presenta las fotografías de las casonas tradicionales del centro de Jalostotitlán con los fragmentos de varias obras de poetas, escritores e historiador principalmente originarios de Jalostotitlán, quienes fueron fascinados por el estilo arquitectónico de casonas y la vida en ellas. El autor señala que lo que distingue a Jalostotitlán de otras ciudades de la región de los Altos de Jalisco es la fuerte influencia española que había recibido esta localidad desde el siglo XVI al XIX y que el legado español se refleja en la arquitectura tradicional de las casonas del centro de Jalostotitlán. Sin embargo, advierte que este patrimonio cultural de los jalostotitlenses está en crisis en la actualidad.

A mediados del siglo XX, cuando comenzó el auge del comercio, gran parte de las casonas céntricas iniciaron un cambio transformador que sigue hasta nuestros días. Muchas de ellas céntricas, propias para el comercio, empezaron a abrir las ventanas de sus salas al exterior transformándolas en ingresos de comercios alternos a su hogar. Este hecho puede considerarse como la decadencia de la arquitectura de las casonas tradicionales en Jalostotitlán. Aunado a las que por intestados permanecen décadas sin habitarse y sin mantenimiento lo que las lleva "inevitablemente" a la destrucción física y a su demolición.

Los esfuerzos infructuosos y los grandes errores de administraciones municipales que no han preservado y marcado lineamientos (o los han transformado erróneamente), el patrimonio arquitectónico no ha sido cuidado con celo ni de una forma ordenada, estos hechos han sido la principal perdida de los inmuebles

${ }^{210}$ Luis Jesús Ramírez Jiménez, 2002, Casonas del Pasado en el Corazón de los Altos de Jalisco, Jalostotitlán, Gráfica Positiva. 
patrimonio arquitectónico de esta ciudad. [...] Sirva esta modesta obra como un estímulo para la valorización y conservación de este patrimonio. ${ }^{211}$

El autor, por un lado, manifiesta una crítica a la carencia entre la autoridad civil y los habitantes de los esfuerzos y la conciencia de conservación del patrimonio arquitectónico, y por el otro lado, espera que su obra sirva para fomentar la valorización y la conservación de las casonas tradicionales entre los jalostotitlenses. Lo que se puede observar en este texto es que la nostalgia no es un simple sentimiento con el cual el autor presenta los patrimonios arquitectónicos de su ciudad en forma romántica para llevar al lector a dirigir una mirada retrospectiva hacia Jalostotitlán, sino que aparece como una forma de crítica cultural a partir de la cual intenta conducir al lector a las reflexiones sobre el presente y el futuro de su terruño.

\section{5) Proyecto cultural "Sin fronteras"}

En el año 2003, se publicó en Jalostotitlán el primer número de la revista Sin fronteras, una revista del Consejo Ciudadano para el Desarrollo Cultural Municipal. En el capítulo anterior, presenté un diagnóstico realizado por el gobierno municipal sobre la realidad cambiante del municipio ante el impacto de la migración entre los jóvenes. En este diagnóstico, por un lado, se interpreta que las influencias derivadas de Estados Unidos han llevado a la nueva generación de los habitantes a apropiarse del estilo y la visión de vida que no coinciden con los valores tradicionales de la población, por otro lado, se sostiene la importancia del fomento de actividades culturales para orientar a los jóvenes hacia una formación personal y cultural y una visión de vida alternativa a la idea de superación y progreso estrechamente ligada al Norte. Retomando este análisis del gobierno municipal, esta organización civil de Jalostotitlán ha propuesto y fomentado en los últimos cinco años distintas actividades artísticas y culturales entre niños y jóvenes con la colaboración del gobierno municipal a través de la Casa de la Cultura, tales como, el proyecto de la promoción de la lectura entre los estudiantes de escuelas

${ }^{211}$ Ramírez (2002: 15). 
primarias y secundarias, talleres, exposiciones y concursos de danza folklórica, arte plástica, música y canto.

Otro proyecto cultural importante de esta organización civil es la publicación de la revista Sin fronteras, una revista bilingüe sobre la migración, cuyo objetivo principal es mantener un vínculo entre los migrantes y los habitantes para concientizar a dos grupos sociales de los jalostotitleses sobre la realidad que están viviendo los migrantes en el otro lado de la frontera y la realidad cambiante que están viviendo los jalostotitlenses en el terruño. En la primera página de la revista del primer número, se publicó un artículo titulado "Regreso a la 'Patria chica'”, donde se explica el objetivo de la revista:

En definitiva...debemos dejar la tierra que nos vio nacer para experimentar la sensación que surge de nuestro interior al regresar al terruño y de inmediato el encuentro con los nuestros, con sitios u hogares que nos son familiares, que vienen en cascadas los recuerdos de tiempo que se ha llevado el correr de los días.

Para unos o para muchos el corazón acelera su paso al momento de observar a lo lejos las torres del santuario, otros sienten una oxigenación al momento de pisar la tierra en que dieron sus primeros pasos a la vida.

De nuevo el emigrante cree poseer los valores que obtuvo de sus mayores y la tierra que le permitió echar raíces de lo que representa una propiedad intrínseca.

"Sin fronteras", surge como una inquietud de mantener una comunicación estrecha entre los que habitamos el terruño con los emigrantes, de escuchar y transmitir sus inquietudes y el anhelo perenne de lo que quisieran convertir en realidad para beneficio de la tierra.

"Sin fronteras" es una publicación del Consejo Ciudadano para el Desarrollo Cultural Municipal que nace como una respuesta a la necesidad de mantener un vínculo de la realidad de "los de allá" y los cambios que se han generado entre "los de acá". ${ }^{212}$

Debido a que el objetivo de la revista es el mantenimiento del vínculo entre los migrantes y los habitantes del municipio, 200 de 500 ejemplares del primer número de la revista se repartieron en Estados Unidos. En cuanto al contenido, la revista se compone de artículos escritos por los habitantes de Jalostotitlán sobre tradiciones y costumbres de esta localidad y de México, biografías de personajes históricos originarios de Jalostotitlán, historia local, actividades culturales que se fomentan en el municipio y algunos problemas sociales emergentes entre los jóvenes del municipio y artículos sobre la actualidad de la situación migratoria.

${ }^{212}$ Sin fronteras. Año. 1. No.1. 2003. p.1. 
Todos los artículos tienen traducción en inglés. Aunque hasta ahora se han publicado principalmente los artículos enviados por los habitantes del municipio y artículos escritos por algunos investigadores y periodistas sobre el fenómeno migratorio, también se ha convocado a los migrantes para hacer sugerencias y recomendaciones que desean publicar en la revista.

Después de la publicación del primer número de la revista, la misma organización convocó al Foro Sin fronteras, y el 8 de marzo de 2003 se realizó en el auditorio de la Casa de la Cultura. En este evento se analizaron y discutieron las principales causas del fenómeno migratorio del caso de Jalostotitlán y sus impactos en la vida local con la participación de los siguientes ponentes: Agustín Escobar Latapí, quien hizo una investigación sobre el impacto de la reforma migratoria en el lugar de origen de los migrantes en el municipio de Jalostotitlán en los años ochenta; Alfonso Reynoso Rábago, antropólogo originario de Jalostotitlán, y Antonio González Márquez, director de la Fundación Jalostotitlán radicado en California. El objetivo principal de este evento era concientizar a los jalostotitlenses acerca de la trascendencia que tiene la migración hacia Estados Unidos en el municipio y ofrecerles un espacio de reflexión sobre este fenómeno.

Lo que se destaca en estos proyectos culturales del Consejo Ciudadano para el Desarrollo Cultural Municipal es que hay un cambio importante en la postura local hacia el fenómeno migratorio y los migrantes. A diferencia del discurso negativo localmente difundido sobre la migración y los migrantes que presenté en el capítulo anterior, esta organización civil, en vez de rechazar a los migrantes como "culpables de la destrucción cultural", los reconoce como parte de la sociedad jalostotitlense y acepta que la migración es un fenómeno que no sólo forma parte de la vida de los migrantes, sino también de la mayoría de los habitantes. El título de un verso escrito por un profesor originario de Jalostotitlán, presentado en la tapa trasera del segundo número de la revista, simboliza esta postura hacia la migración y los migrantes.

"Jalos, Pueblo de Viajeros"

Allá, donde el sol ilumina día con día 
y con sus rayos cobija a los ricos y los pobres, emerge un pueblo de bullicio y esperanza con gente amable, laboriosa y noble.

Gente viajera que en el mundo ha buscado el porvenir pa' su gente, a otros países ha llegado de mojado con su tesón y su fe como aliciente.

De ese pueblito de los altos de jalisco con el nombre de Jalostotitlán fue bautizado, ¡de ahí merito! salí para otras tierras hasta llegar a este país, tierra de emigrados.

No es nada fácil olvidar lo que es tu origen, es doloroso dejar el pueblo abandonando, se extraña tanto a la familia, a los amigos; se añora todo lo que ha sido tan sagrado [...]

Y cuando llegue a invadirme la nostalgia y sienta ganas de todo abandonar, Pienso Jalos, sus fiestas y sus plazas;

soñando con su tierra sin igual $[\ldots]^{213}$

Como se titula, en estos versos, se considera que Jalostotitlán es un pueblo no sólo de aquellas personas que viven en este lugar, sino que es también un lugar hecho de la gente que emigra a las tierras lejanas en busca de un porvenir mejor para su tierra natal y para su gente, y que esta forma de vivir lejos del terruño y esta forma de añorarlo también son parte de las características de jalostotitlenses.

Otra implicación importante de estos proyectos culturales de esta organización civil sobre la migración es que al reconocer a los migrantes como parte de la sociedad local, aquellos sujetos que se encargan de la conservación de la cultura local y el desarrollo cultural no son solamente los habitantes de la localidad. Más bien, en la situación actual en que las tradiciones y la cultura local se enfrentan inevitablemente con los cambios socioculturales por las influencias de otros lugares y otros países, se considera que tanto los habitantes como los migrantes son los sujetos que se encargan de la conservación y la reconstrucción de la cultura local, y que la reconstrucción de la cultura local se busca a través del

${ }^{213}$ Alberto Sánchez Rodríguez, 2003, “Jalos, Pueblo de Viajeros”, en Sin Fronteras, 1 (2). 
diálogo, las reflexiones y la colaboración entre estos dos sujetos. Cabe destacar que en esta postura de esta organización civil, la cultura no se define como algo dado y heredado del pasado durante generaciones sin reflexión, sino que es lo que se objetiva y a lo que se asigna nuevo sentido tanto por los habitantes como por los migrantes en el proceso de migración y en el proceso del cambio sociocultural en su lugar de origen.

Además de fomentar entre los habitantes el entendimiento sobre la actualidad del fenómeno migratorio y sobre su importancia para la sociedad jalostotitlense y el reconocimiento de la presencia de los migrantes en esta sociedad local, lo que intenta esta organización civil de forma concreta para hacer una ruptura con las barretas entre los ausentes y los habitantes, es intervenir en la formación de las imágenes del terruño que describen los migrantes en su mente a partir de sus experiencias de separación del terruño y de la vida cotidiana en la tierra extranjera, para que sus terruños imaginarios reflejen, de alguna manera, las visiones de los habitantes sobre el terruño. A través de los artículos enviados por los habitantes y la presentación de los proyectos del fomento cultural entre los jóvenes y los problemas sociales que preocupan a los habitantes, esta revista busca transmitir a los migrantes las imágenes del terruño vistas desde el punto de vista de los lugareños para compartir con los primeros el interés, la preocupación y la visión sobre el futuro de Jalostotitlán. En este sentido, la revista Sin fronteras es un" medio" de producción de imágenes que busca fusionar distintas visiones sobre Jalostotitlán para construir un terruño imaginario colectivo, un medio de comunicación que busca un entendimiento mutuo entre los migrantes y los habitantes.

En este apartado, he presentado los textos publicados en Jalostotitlán, en los cuales la nostalgia aparece como uno de los principales temas o como una forma de narrativa sobre esta localidad. Sin embargo, la nostalgia que se manifiesta en estos textos es más que un simple tema y una forma de narrativa sobre el pasado y el terruño de los autores. En los textos, la nostalgia también se utiliza como recurso económico y capital social y cultural. 
En primer lugar, este sentimiento es utilizado por los autores y las editoriales como recurso económico, dado que es un tema que puede atraer a los ausentes quienes son los principales consumidores de los libros. Por eso, agosto, el mes en que se celebran las fiestas patronales, y al mismo tiempo regresan el mayor número de los ausentes, ha sido el período del año en que las editoriales preparan la publicación de libros y buscan la mayor venta.

En segundo lugar, la nostalgia se usa como capital social porque lo que buscan algunos textos es fomentar la comunicación y el entendimiento mutuo entre los ausentes y los habitantes. Como demuestran varios casos de la publicación de los libros y la revista que presenté aquí, se observa una nueva forma de relación social que se establece entre los migrantes y los ausentes a través de la publicación: la relación entre la editorial, el autor y el lector. A través del uso de la nostalgia como el tema de los textos y como la forma de narrativa, algunos autores y la editorial de la revista intentan acercarse al lector que tiene las mismas experiencias o no las tiene para compartir sus ideas y sus emociones personales con el lector o para fomentar el reconocimiento social de otras visiones sobre Jalostotitlán y la presencia de los otros en la sociedad jalostotitlense.

Por último, los autores usan la nostalgia como capital cultural en dos sentidos. En primer lugar, los autores de los libros que revisé en este apartado usan la nostalgia como una forma de narrativa para invitar al lector a dirigir las miradas hacia el pasado. A partir de estas miradas retrospectivas intentan llevarlo a revalorizar el paisaje y las tradiciones del terruño que están desapareciendo en la actualidad y objetivar la cultura local para criticar a las realidades del presente, para dar nuevos significados a los elementos culturales que están desapareciendo y para fomentar la conservación de las tradiciones, costumbres y patrimonios arquitectónicos de Jalostotitlán.

Otra forma del uso de la nostalgia como capital cultural que se puede observar en los textos, es que los autores de libros y la editorial de la revista buscan la creación de terruños imaginarios colectivos entre los jalostotitlenses. Como hemos visto a lo largo de los capítulos de esta tesis, hay varias imágenes de Jalostotitlán que se describen en la mente de los jalostotitlenses con la 
nostalgia. Esto se debe a que existen distintas formas de distanciarse del terruño adonde los sujetos desean volver: en los procesos migratorios, el desplazamiento físico hacia nuevos destinos separan a los ausentes de su lugar de origen; los años que llevan viviendo en las tierras ajenas también los separan de su tierra natal; sus experiencia de la vida cotidiana en nuevos destinos que contrastan con la vida que llevaban en su lugar de origen, también despiertan en ellos el sentido de distancia. Estas experiencias de distanciarse de su lugar de origen hacen a los ausentes objetivar el lugar donde habían vivido, la matriz de la cultura local y las tradiciones que habían dejado o que han tratado de conservar en sus nuevos lugares de residencia. Sin embargo, la nostalgia no es necesariamente un sentimiento que experimentan aquellos sujetos que hacen un viaje físico. En el proceso de transculturación como consecuencia de la migración y el fortalecimiento de las conexiones con el mundo exterior, los cambios socioculturales percibidos por los sujetos también crean el sentido de distancia, no sólo entre los ausentes que vivieron una parte de su vida ahí antes de estos cambios, sino también entre los habitantes. Es otra forma de experimentar la distancia y la separación del terruño que también hace a los sujetos objetivar el terruño y la cultura local.

Lo que intentan los autores de los libros y la editorial de la revista es transmitir a los demás jalostotitlenses las narrativas de la nostalgia enunciadas desde distintas experiencias y diferentes posicionamientos de los autores para fusionar un terruño imaginario con otros y crear memorias colectivas y terruños imaginarios colectivos, a partir de los cuales intentan construir un terruño en donde converjan múltiples miradas nostálgicas que dirigen los jalostotitlenses desde distintas experiencias de "distancia".

Este movimiento literario de los jalostotitlenses, de alguna manera, nos recuerda el concepto de comunidad imaginada que propuso Benedict Anderson (1983). En su libro, él señala que la producción de los textos impresos en el idioma nacional ha jugado un papel importante en el proceso de construcción del estadonación. La difusión de los textos en el mismo idioma les ha facilitado a los individuos, que en realidad no tienen ninguna interacción social con otros que 
viven dentro de los territorios nacionales, a imaginar que ambos pertenecen al mismo país. En este sentido, él define como comunidad nacional imaginada el estado-nación que se construye en este modo de operación de los símbolos sobre la imaginación y la capacidad de percibir la realidad del espacio físico.

En el caso de Jalostotitlán, este movimiento literario busca intervenir en la formación de los sentimientos hacia esta localidad, la capacidad de percibir la realidad del presente y la imaginación sobre el pasado y el futuro y ganar más terreno simbólico entre los jalostotitlenses que viven dispersos dentro y fuera de los territorios nacionales, a través de la difusión de los textos sobre Jalostotitlán como símbolos que representan los terruños imaginarios de los autores. En este sentido, es una práctica cultural transnacional que envuelve tanto a los habitantes como a los ausentes en el proyecto de construcción de un terruño imaginado, es decir, el proyecto de la reorientación de los sentimientos, la imaginación, la percepción de la realidad, las memorias, las identidades y la forma de mirar a Jalostotitlán, a través de la producción y la difusión de los textos sobre esta localidad, para que todos sientan la nostalgia hacia el mismo terruño imaginario.

\section{CONCLUSIONES}

El día 15 de agosto, poco antes de las cinco de la tarde, había una multitud que llenaba la entrada del templo parroquial de Nuestra Señora de la Asunción y la plaza ubicada enfrente del templo. Las personas con vestidos formales, con sus familias o con cámaras de video estaban esperando el inicio de la procesión con la imagen original de la Virgen de la Asunción que baja del altar y sale del templo sólo ese día durante todo el año.

Cuando comenzaron a sonar las campanas, en la entrada del templo se asomó la imagen de la Virgen de la Asunción cargada por los feligreses, guiada por monaguillos, miembros de los Caballeros de Colón y sacerdotes. La banda municipal comenzó a tocar instrumentos. La multitud que estaba esperando la procesión en la plaza aplaudió cuando apareció la imagen sagrada de la entrada del templo, e iba participando en la procesión cuando la imagen pasaba por donde se encontraba esperando en la plaza. 
Hasta ese día se habían celebrado dos peregrinaciones al día desde el primero de agosto: una peregrinación de los habitantes de diferentes rancherías cerca del mediodía, otra del gremio y de diferentes sectores de los habitantes de la ciudad en la tarde. El día siguiente, el 16 de agosto, iba a haber la peregrinación de los ausentes. A estas peregrinaciones acompañaba la réplica de la imagen sagrada. Pero, el 15 de agosto, sin manifestar estas divisiones, casi todas las personas que se encontraban en Jalostotitlán participaban en esta peregrinación más importante de agosto, formando parte de la procesión con la imagen sagrada original o la estaban contemplando en las calles de la ciudad.

Conforme íbamos avanzando, la procesión iba creciendo en cuanto al número de personas. Los jóvenes que yo había visto alguna vez en las cantinas, los ausentes con quienes me había entrevistado, mis amigos y otros habitantes que conocí durante el trabajo de campo y un gran número de personas que no conozco estaban participando en la procesión u observándola desde las casas y las calles por donde pasábamos.

Después de una hora y media del recorrido por las calles principales de la ciudad, la imagen de la Virgen de la Asunción llegó al punto inicial de la peregrinación y fue colocada en la escena instalada al lado de la entrada del templo. La multitud que estaba en la procesión fue a la plaza para participar en la misa. Era una misa celebrada al aire libre. La gente miraba un paisaje en el cual la imagen sagrada estaba en el centro, el templo parroquial en el fondo, más atrás el cielo que se extendía inmensamente. Las miradas de personas de diferentes edades, géneros, trabajos y lugares de residencia se dirigían hacia la escena de la misa donde se encontraba la imagen sagrada. Me parecía que la imagen de la Virgen de la Asunción estaba recibiendo con sus brazos abiertos estas miradas que la gente dirigía en silencio hacia ella enviándole distintos mensajes no expresados de agradecimientos y súplicas. Yo también contemplé al símbolo de esta ciudad, el punto en donde convergían múltiples miradas de la gente. Sentía que yo también formaba parte de este paisaje ritual. Sentía la simpatía con las demás personas que se encontraban en el mismo sitio observando el mismo 
objeto, el calor de la sensación amistosa con ellas. Fue una experiencia de comunitas, la emoción de unificación social, el sentido de solidaridad. ${ }^{214}$

Jalostotitlán, el lugar que yo había investigado durante los últimos años es, como esta imagen religiosa, el punto de convergencia de múltiples miradas, expectativas y emociones. Es el lugar con el cual se identifica el sentido de pertenencia de la gente que tiene una diversidad de experiencias y posicionamientos. Es el lugar hacia el cual se dirigen distintos sentimientos de añoranza. Estas múltiples miradas nostálgicas convergen en este lugar que existe físicamente al reincorporar a los ausentes a la vida local en el tiempo ritual. En este sentido, las fiestas de agosto son una ocasión de reencuentro entre los jalostotitlenses que viven en distintos lugares y ocupan diferentes posicionamientos, al mismo tiempo, son rituales que abarcan la heterogeneidad de la sociedad local. Pero, como demuestran las ceremonias religiosas del 15 de agosto, también son momentos en que distintos sectores de los jalostotitlenses experimentan el sentido de vínculo social con los demás a través de la participación en los ritos. Lo que buscan dos prácticas culturales presentadas en este capítulo es, de cierta manera, la creación de un sentido de unificación social y la armonización de sentimientos entre los jalostotitlenses que componen la sociedad local de manera heterogénea.

Lo que se busca en ambos casos etnográficos es crear la noción de ciudadanía y de identidad y la imagen del lugar incluyente que reconocen la heterogeneidad en forma de ser jalostotitlenses y de pertenecer a la localidad. Lo importante es que estas prácticas culturales se dan durante el tiempo ritual en que múltiples miradas de los jalostotitlenses convergen en este lugar. Nuevas formas identitarias y de interpretación sobre la cultura local se presentan y representan en la fase liminal del proceso ritual, en la que suspenden las relaciones sociales jerárquicas en la estructura social de la vida cotidiana y surge el sentido del vínculo humano más igualitario. A partir de este efecto de comunitas, se intentan armonizar distintas formas de nostalgia hacia Jalostotitlán y construir los sentimientos colectivos de nostalgia a través de los cuales se reorientan la

${ }^{214}$ En cuanto al concepto de comunitas, véase Turner (1969; 1974: 231-271). 
dirección y la forma de mirar e interpretar el lugar y la cultura local para recordar el pasado, cambiar el presente e imaginar el futuro de la localidad de manera colectiva.

¿Jalostotitlán que se reconstruye a través de estas prácticas culturales de inclusión no sería un lugar que abraza múltiples miradas de la gente con tolerancia y crea una sensación de pertenecer al mismo lugar de origen como la imagen de la Virgen de la Asunción del 15 de agosto? Si lo fuera, la frase de "la tierra a la que todos quieren volver" sería una invitación tanto a los habitantes como a los ausentes, es decir, a todos aquellos que tienen distintas formas de ser jalostotitlenses a narrar el sentido de pertenencia a esta ciudad en un escenario festivo para construir un terruño imaginario colectivo multicultural en donde diversos estilos de vida y experiencias heterogéneas se envuelven con el término de Jalos o jalostotitlense. 


\section{Conclusiones}

\section{DIVERSAS FORMAS DE NOSTALGIA}

Del capítulo 2 al capítulo 7 de esta tesis, he descrito y analizado varios casos etnográficos relacionados con la nostalgia: las narrativas nostálgicas de los migrantes jalostotitlenses sobre su terruño; la reconstrucción del terruño en el proceso de generalización del retorno temporal masivo de los migrantes en temporada de fiestas locales; las prácticas religiosas de los migrantes que han construido y fortalecido los circuitos simbólicos y emocionales transnacionales entre el lugar de origen y los lugares de destino; la producción, la venta y el consumo de signos de terruño; las polémicas y tensiones sociales por la definición de la imagen del terruño, y las prácticas culturales que redefinen la ciudadanía y la identidad local y construyen los sentimientos colectivos. El análisis de estos casos etnográficos nos han enseñado distintas formas de nostalgia que aparecen tanto en la vida interior y social de los migrantes y de los habitantes de su terruño como en los procesos transnacionales.

En el capítulo 2, presenté una tipología de la forma narrativa nostálgica de los migrantes jalostotitlenses sobre su terruño. Lo que esta tipología demuestra son varias formas de percepción de la distancia entre su país receptor y su terruño. En estas narrativas, se reflejan sus experiencias de alienación del tiempo y espacio ritual de su tierra natal, los lazos sociales con aquellos seres queridos que dejaron en su lugar de origen, los roles y posiciones sociales que pueden asumir en su terruño, el sentido de pertenencia y la identidad tradicional de género, a los cuales los migrantes han considerado como elementos culturales importantes para transformarse en seres sociales ideales y distintos de lo que son ahora en Estados Unidos. Para aquellos migrantes cuyo yo ideal está fragmentado por la distancia espacial y temporal, por el contraste sociocultural y por su condición de vivir como subalternos en Estados Unidos, los terruños imaginarios que se construyen en la memoria y en la imaginación a partir de sus posicionamientos, son un lugar de

liberación de las experiencias de alienación; una tierra que restaura su yo fragmentado y les cura las heridas de alienación; un espacio propio y de 
pertenencia y una "tierra prometida" que les permite obtener un yo ideal. En este sentido, la nostalgia es un deseo del sujeto alienado de transformarse en un ser social diferente de lo que es ahora y de llegar a un lugar distante que le permita realizar esta transformación.

Sin embargo, como he explicado del capítulo 3 al capítulo 7, la nostalgia no sólo es un sentimiento que les hace a los sujetos alienados construir las imágenes del terruño que flotan moviéndose entre el imaginario y la dimensión de representación. Más bien, la nostalgia aparece como una subjetividad que saliendo de estas dimensiones, influye sobre la realidad que viven los jalostotitlenses tanto en los lugares de destino en Estados Unidos como en su terruño en México y como el motor de la construcción de los vínculos transnacionales y de la transformación de sus prácticas espaciales, temporales y culturales y sus actividades económicas.

En el capítulo 3, exploré la formación de la estructura de sentimientos hacia el terruño que estimula a los migrantes a revalorar el espacio rural y a viajar a su lugar de origen, a partir de enfocarme en la transición del campo a la ciudad tanto en su terruño como en sus lugares de destino en Estados Unidos, en el surgimiento de las vacaciones de los migrantes y en la articulación entre estos procesos. Además, analicé cómo la nostalgia hacia el terruño como espacio rural lúdico influye sobre el proceso reciente de transformación de Jalostotitlán. En este proceso, las imágenes del pueblo rural lúdico e idealizado han sido apropiadas por el sector comercial, los habitantes y el gobierno municipal y se han materializado en los escenarios festivos de Jalostotitlán.

La forma de nostalgia que se revela en este capítulo es que la nostalgia no sólo es un sentimiento que se construye como una reacción a los cambios que se han dado en el entorno social transnacional de los migrantes, sino que también es una subjetividad que opera sobre las prácticas espaciales de los migrantes y la realidad de su terruño. Los motivos del retorno temporal de los migrantes, algunas actividades del tiempo libre de los jalostotitlenses y el consumo de los migrantes de los productos y servicios que representan signos de "rancho" y "pueblo rural" están estrechamente relacionados con la nostalgia hacia el espacio rural. Este 
proceso de transformación de Jalostotitlán les ha permitido a los migrantes anular de manera hiperreal la alienación que experimentan en la vida cotidiana en las zonas urbanas en Estados Unidos a través del viaje físico al terruño donde se reestrena el ambiente del "pueblo rural" lúdico e idealizado.

En el capítulo 4, analicé las prácticas religiosas de los migrantes que se han desarrollado tanto en los lugares de destino como transnacionalmente en torno a las imágenes sagradas de su terruño. En los lugares de destino en Estados Unidos, los migrantes jalostotitlenses han desarrollados las prácticas religiosas a través de la inserción de los símbolos religiosos del terruño y la devoción por ellos en el país receptor. Pero estas prácticas religiosas no son simples copias de los rituales de su terruño. Más bien, algunas de ellas y los símbolos religiosos locales han adquirido significados distintos a los originales como demuestran el caso de la fiesta patronal de la Virgen de la Asunción en Turlock y el de la creencia popular en Santo Toribio Romo. Asimismo, exploré cómo las prácticas religiosas populares de los migrantes han sido apropiadas por las instituciones religiosas para incorporar a la población migrante tanto a las iglesias locales en el país de origen como a las iglesias en el país receptor. A través del entrecruzamiento de las prácticas religiosas populares de los migrantes con las prácticas institucionales, se han construido y fortalecido los vínculos sociales, simbólicos y emocionales transnacionales entre el lugar de origen y los lugares de destino de los migrantes.

En esta dimensión religiosa de la vida de los migrantes, la nostalgia hacia el terruño como el lugar sagrado es una subjetividad que ha sostenido la construcción y el fortalecimiento de los circuitos simbólicos y emocionales en los cuales el terruño de los migrantes se convierte en el lugar de origen de la fe católica. Asimismo la nostalgia aparece como el motor tanto para la reinvención de las tradiciones y el desarrollo de la parroquia en su terruño como para el desarrollo de las prácticas religiosas de los migrantes y su incorporación a las iglesias locales en los lugares de destino. A través de estas prácticas religiosas que extienden los circuitos simbólicos religiosos en ambos lados de la frontera, los migrantes han tratado de acercarse al lugar sagrado para mantener su identidad religiosa y evitar la alienación de lo sagrado. 
En el capítulo 5, analicé las actividades comerciales de los jalostotitlenses que se han insertado en el "mercado de la nostalgia" tanto en su terruño como en Estados Unidos, a partir de enfocarme en los productos y servicios que representan signos de terruño, en los puntos de entrecruce entre la dimensión emocional, la simbólica y la económica de la vida de los migrantes y en la relación entre la nostalgia, la identidad y el consumo cultural. En la dimensión económica del espacio de vida de los migrantes que se extiende más allá de la frontera entre México y Estados Unidos, la nostalgia hacia México y el terruño ha sido la base del deseo adquisitivo de los migrantes y el patrón de consumo que fundamenta el mercado de la nostalgia, y al mismo tiempo, se ha utilizado como eslogan publicitario por el sector comercial tanto en la sociedad receptora como en su lugar de origen.

Los signos de terruño que se producen, circulan y se consumen en este mercado, son elementos importantes que convierten los objetos y servicios en mercancías en las que los consumidores identifican el valor simbólico y emocional, aumentan el valor mercantil de los objetos y de servicios y marcan la diferencia con otros productos y sitios de competencia, dado que estos signos juegan un papel importante para crear y fortalecer el vínculo simbólico y emocional con sus terruños de los cuales la migración separa físicamente a los consumidores. Si la construcción de terruños imaginarios a través de las memorias y la imaginación es una forma para anular la alienación que experimentan los migrantes en el país receptor, los migrantes también han tratado de restaurar sus memorias fragmentadas sobre sus terruños y su yo ideal fragmentado y reconstruir sus identidades, a través del consumo y la posesión de los signos de terruño que nutren sus terruños imaginarios.

El retorno temporal de los migrantes en temporada de fiestas locales, que se ha convertido en un fenómeno masivo desde la segunda mitad de los años ochenta, ha creado un contexto en que las miradas nostálgicas de los migrantes se contactan con la realidad de su terruño. En su lugar de origen, que ahora se convierte en una zona de contacto entre los ausentes y los habitantes y entre los terruños imaginarios de los migrantes y la realidad del terruño, por un lado, las 
imágenes del terruño que los migrantes han descrito en su mente se materializan y la cultura tradicional local se reconstruye e incluso, se mercantiliza. Por otro lado, en este proceso de reconstrucción del lugar de origen de los migrantes, la nostalgia aparece como un sentimiento paradójico. La materialización de la imagen del terruño como un espacio lúdico y de libertad para los jóvenes ha despertado en el sector conservador de la población no migrante, que define la imagen del terruño de un modo diferente, la alienación de su cultura, de sus tradiciones, de su identidad local y de sus fiestas y el deseo de recuperarlas. En esta forma narrativa sobre la nostalgia de resistencia, se propone un discurso de identidad local que esencializa al pasado y a la pureza de la cultura y las tradiciones. Este localismo, que delinea los límites culturales en las conexiones transnacionales entre Jalostotitlán y Estados Unidos y considera a los migrantes como "otros", ha despertado en los migrantes una nueva alienación de la identidad y ha provocado polémicas y tensiones sociales entre los migrantes y la población no migrante. En este sentido, el terruño se ha convertido en una zona de contacto y paradójica donde distintos sentimientos y visiones sobre el terruño y la cultura local se contactan y se chocan. Lo que pretendí revelar a través del análisis de distintos sentimientos que están en polémica, fueron la forma de nostalgia como una forma de crítica cultural y la multiplicidad de posicionamientos en que se sitúan los sujetos nostálgicos al enunciar sus sentimientos y sus críticas.

Entonces, ¿será posible resolver esta polémica y tensión social que han surgido del choque entre distintas miradas nostálgicas hacia el terruño? ¿Será posible reconstruir el terruño y la cultura local en los cuales tanto los migrantes como la población no migrante de Jalostotitlán puedan encontrar el sentido de pertenencia y formas para anular sus experiencias de alienación?

En el capítulo 7, expliqué que yo había encontrado una respuesta optimista a estas preguntas en las prácticas culturales locales que parecen llevar a la práctica la frase "¡La tierra a la que todos quieren volver!”, un eslogan de las fiestas locales de Jalostotitlán. En este capítulo, presenté dos casos etnográficos: el caso del evento de la entrega del reconocimiento a jalostotitlenses distinguidos, donde se redefine la diversidad en forma de ser jalostotitlense sin limitar la ciudadanía 
cultural sólo a aquellos que vivan dentro de los territorios locales; el caso del movimiento literario que a través de la publicación de textos sobre Jalostotitlán busca profundizar en la comunicación entre los migrantes y los habitantes y construir los sentimientos colectivos que guían a ambas categorías de los jalostotitlenses, es decir, los migrantes y la población no migrante, a la reconstrucción de la localidad, la cultura local e identidades.

Mi interpretación de estos dos casos de las prácticas culturales locales es que en las fiestas de Jalostotitlán, a través de estas prácticas culturales, se armonizan las relaciones sociales y sentimientos tensos entre los jalostotitlenses que se sitúan en distintos posicionamientos y se construye un escenario festivo donde se crean y se representan la noción de ciudadanía y de identidad y el terruño imaginario multicultural e incluyente que reconocen la heterogeneidad en forma de ser jalostotitlenses y de pertenecer a la localidad.

\section{ECONOMÍA POLÍTICA TRANSNACIONAL DE LA NOSTALGIA}

Entonces, ¿de qué manera podemos explicar la nostalgia al sintetizar distintas formas de este sentimiento hacia el terruño que he explicado del capítulo 2 al capítulo 7 ?

La nostalgia de los migrantes jalostotitlenses hacia su terruño es un sentimiento que ha surgido de la alienación que experimentan de varios modos en el país receptor. Pero, para anular la alienación y satisfacer su nostalgia en los lugares de destino en Estados Unidos, ellos han conservado las prácticas religiosas, tradiciones y costumbres de su lugar de origen y consumen los objetos y servicios que representan signos de terruño. Estas prácticas de los migrantes en Estados Unidos han creado una cultura local de su terruño desterritorializada en el país receptor y han contribuido de manera importante en la construcción y fortalecimiento de las conexiones sociales, económicas, simbólicas y emocionales entre su lugar de origen en México y sus lugares de destino en Estados Unidos. ${ }^{215}$

La nostalgia de los migrantes no es utilizada solamente por ellos mismos para desarrollar sus prácticas culturales, sino también por distintos actores en el

${ }^{215}$ Véase el concepto de desterritorialización que propone Appadurai (1996). 
país receptor que han tratado de acercarse a la población migrante. La nostalgia ha sido explotada y utilizada como un discurso con una enorme fuerza de absorción para incorporar a las iglesias católicas en sus lugares de destino a la población migrante, que es un sector importante de feligreses para el desarrollo de sus parroquias, y para atraer a los migrantes al mercado de consumidores hispanos, donde los migrantes han sido vistos como consumidores potenciales por los productores y proveedores de este mercado.

Por su parte, la nostalgia es un sentimiento que ha sostenido los motivos del retorno temporal de los migrantes y de su consumo en el lugar de origen en México. A través del retorno temporal masivo en temporada de fiestas locales y el consumo de los migrantes, la economía local se revitaliza y las tradiciones y las fiestas locales se reconstruyen, e incluso se mercantilizan para reincorporar a los migrantes a la sociedad local. En el lugar de origen, la nostalgia también se utiliza como discurso para acercarse a los migrantes por el sector comercial, la iglesia, el gobierno municipal y los escritores de Jalostotitlán.

Asimismo, a nivel local, por un lado, la nostalgia es adoptada como una forma de crítica cultural por aquel sector conservador de la población no migrante que propone un localismo de resistencia a los cambios socioculturales en Jalostotitlán. Por el otro lado, la forma narrativa nostálgica sobre el terruño es utilizada en las prácticas culturales que buscan el fortalecimiento de la comunicación estrecha entre los migrantes y los habitantes y la reconstrucción del lugar e identidades incluyentes.

En resumen, lo que se puede observar en la formación, la explotación y el uso de la nostalgia en los casos etnográficos que he presentado a lo largo de la tesis, es que existen las relaciones entre la formación de los sentimientos de los sujetos alienados hacia el terruño, sus efectos socioeconómicos, culturales y políticos y la construcción de los vínculos transnacionales. En este proceso, la formación de la nostalgia no se puede separar de las realidades y fuerzas socioeconómicas, culturales y políticas que rodean tanto el lugar de origen como los lugares de destino de los migrantes. 
Se podría definir a este proceso, con el término de economía política transnacional de la nostalgia. ${ }^{216}$ Es una economía política que ha surgido en distintas dimensiones de la vida de los migrantes y que opera tanto en el nivel local del lugar de origen y de los lugares de destino de los migrantes como transnacionalmente, en la cual la nostalgia es utilizada como el recurso económico, el capital social y cultural, el instrumento político y el motor de la construcción y fortalecimiento de las conexiones transnacionales por distintos actores tanto en el país receptor como en su lugar de origen.

Cabe mencionar que la base de esta economía política que se expande más allá de la frontera entre México y Estados Unidos, es la expansión espacial y temporal de la nostalgia. La nostalgia no es un sentimiento que se despierta solamente en aquellos migrantes que experimentan la separación de su tierra natal y de sus seres queridos y la alienación en la sociedad receptora. Tampoco es un sentimiento que se expresa solamente en los lugares de destino. Más bien, es una subjetividad que les impulsa a los migrantes a viajar a su terruño, y es el motor de la transformación del terruño, la cual les ha provocado otra nostalgia a aquellos que se quedan en este lado de la frontera. En este sentido, la nostalgia es un sentimiento que se expande espacialmente entre la sociedad emisora y la receptora.

Además, la nostalgia hacia el terruño no necesariamente es un sentimiento exclusivo de aquellos que habían vivido antes o viven actualmente ahí, porque los terruños imaginarios de los migrantes y sus sentimientos hacia ese lugar se pueden "heredar" y transmitir a sus hijos que no lo conocen, por medio de las narrativas de sus padres y las cosas del lugar de origen que llevan los migrantes a los lugares de destino y/o por medio de las imágenes del terruño y los mitos de retorno que producen los actores que intentan a acercarse a los migrantes y sus familias en la sociedad receptora. Esta "nostalgia heredada" también les impulsa a

${ }^{216}$ La economía política de la nostalgia es un término que usa Edward Simpson (2005) para explorar un caso etnográfico sobre el surgimiento y la caída de la nostalgia como una forma narrativa colectiva de los sobrevivientes del sismo que ocurrió en Gujarat, India, en el año 2001. Mientras Simpson propone este concepto para entender el proceso regional, yo agrego un adjetivo transnacional a este concepto para explorar cómo ha surgido y opera una economía política de la nostalgia en el contexto transnacional. 
nuevas generaciones y les abre la posibilidad de experimentar la "nostalgia construida" a partir de un acto de retorno. En este sentido, la economía política transnacional de la nostalgia es un proceso que no sólo se expande en el espacio, sino también en términos generacionales.

En esta economía política transnacional de sentimientos, en la cual varios actores producen y difunden constantemente símbolos y discursos que operan sobre la dimensión emocional de la vida de los individuos, la nostalgia no necesariamente es un sentimiento que desaparece al experimentar la satisfacción de realizar el sueño de retorno. Porque en este caso, el viaje al terruño no significa librarse de las "redes" simbólicas y emocionales transnacionales con las cuales intentan atrapar a los migrantes aquellos actores que rodean a sus vidas. Más bien, este viaje significa que los migrantes se vuelven más expuestos a las imágenes del terruño que producen los actores locales de terruño, tales como, la iglesia, el sector comercial, el gobierno local.

Sin embargo, esta economía política que ejerce una enorme fuerza simbólica sobre la vida de los migrantes puede perder su durabilidad y debilitarse cuando ellos despiertan de sus sueños del terruño y de la nostalgia, es decir, cuando experimentan una desilusión y una brecha negativa entre sus terruños imaginarios idealizados y la realidad del lugar de origen en sus viajes de retorno. Del capítulo 3 al 5, ilustré cómo los terruños imaginarios, que los migrantes construyeron de una manera idealizada con la nostalgia, han sido apropiados por la sociedad local y se han materializado en el lugar de origen. En estos casos, el terruño es un espacio sociocultural que tiene cierta similitud con los terruños imaginarios de los migrantes pero es más verosímil y real que los imaginarios. En este proceso de materialización del imaginario, el terruño como espacio físico se convierte en el "terruño imaginado", es decir, un conjunto de símbolos y discursos aterrizados e incrustados en el lugar que controlan y nutren en forma organizada las memorias, la imaginación y los sentimientos de los individuos sobre ese lugar. No obstante, como demuestra el caso analizado en el capítulo 6 , este proceso le ha provocado al sector conservador de la población no migrante un sentido de pérdida del terruño, su cultura y tradiciones, del cual ha surgido una forma narrativa local que 
critica a los migrantes. Ironicamente, esta forma narrativa acerca de la nostalgia, la identidad y la cultura local les ha provocado a algunos migrantes otra experiencia de alienación en su terruño, la cual los puede despertar de sus sueños de reafirmar el sentido de pertenencia en su lugar de origen.

Si la economía política transnacional de la nostalgia tiene la posibilidad de funcionar como un modelo alternativo de desarrollo sustentable para las sociedades rurales mexicanas, lo importante es encontrar un camino para superar las tensiones sociales y emocionales que surgen entre los migrantes y la población no migrante bajo una nueva "situación pos-colonial" en donde coexisten la situación asimétrica de poder y la respuesta severa o la resistencia local.

En este sentido, nuevas prácticas transculturales jalostotitlenses que describí en el capítulo 7 son un caso etnográfico valioso y sugerente. La transculturación no es un conpecto que sólo significa la "deculturación" o destrucción cultural en el contexto del contacto entre personas y culturas diferentes bajo una relación asimétrica de poder, sino también el proceso de creación de nuevas formulaciones culturales a través de la mezcla y yuxtaposición de personas y elementos culturales diferentes. Lo que quiero destacar aquí es precisamente este segundo significado. El evento de la entrega del reconocimiento a jalostotitlenses distinguidos y el movimiento literario en Jalostotitlán son prácticas que buscan redefinir la identidad local y la forma de pertenecer al terruño a partir de reconocer y yuxtaponer diferentes formas de ser jalostotitlenses y diferentes terruños imaginarios. Para construir una noción colectiva de ciudadanía cultural y terruños imaginarios incluyentes tanto para aquellos que viajan como para otros que se quedan en el terruño, estas prácticas intentan construir nuevas formas colectivas de narrar la nostalgia hacia el terruño. En este sentido, estas prácticas que se observan en Jalostotitlán son un proyecto cultural en el cual yo identifico la posibilidad de explotar la economía política transnacional de la nostalgia como un nuevo modelo de desarrollo cultural sustentable. 


\section{Bibliografía}

A Hispanic Business Inc. Research Unit

2003 U.S. Hispanic Consumers in Transition: A Descriptive Guide, Santa Barbara, Hispanic Business Inc.

ALVAREZ, Robert R.

1995 "The Mexican-US Border: The Making of and Anthropology of Borderlands", en Annual Review of Anthropology, 24, pp. 447-470.

ANDERSON, Benedict

1983 Imagined Communities: Reflections on the Origin and Spread of Nationalism, Londres, Verso.

ANDERSON, Donald Lee y Godfrey Tryggve ANDERSON

1984 "Nostalgia and Malingering in the Military during the Civil War", en Perspectives in Biology and Medicine, 28, pp. 156-166.

APPADURAI, Arjun

1988 "Introduction: Place and Voice in Anthropological Theory", en Cultural Anthropology, 3 (1), pp. 16-20.

1991 "Global Ethnoscapes: Notes and Queries for a Transnacional Anthropology", en Recapturing Anthropology: Working in the Present, Richard G. Fox (ed.), Santa Fe, New Mexico, School of American Research Press, pp.191-210.

1991a La vida social de las cosas: perspectiva cultural de las mercancías, México, Grijalbo.

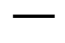

1996 Modernity at Large: Cultural Dimensions of Globalization, Minneapolis, University of Minnesota Press.

AUGÉ, Marc

1998 La guerra de los sueños: Ejercicios de etno-ficción, Barcelona, Gedisa.

1998a El viaje imposible: El turismo y sus imágenes, Barcelona, Gedisa.

1998b Las formas del olvido, Barcelona, Gedisa.

BACA MONTAÑO, Pedro 
2003 "Toribio Romo. Santo coyote de los braceros", en Revista bi: revista del México binacional, 1 (3), pp. 11-13.

BASCH, Linda, Nina GLICK SCHILLER y Cristina SZANTON BLANC

1994 Nations Unbound: Transnational Projects, Postcolonial Predicaments, and Deterritorialized Nation-States, Amsterdam, Gordon and Breach

BAUDRILLARD, Jean

1978 Cultura y Simulacro, Barcelona, Editorial Kairós.

BESSERER, Federico

1999 "Estudios transnacionales y ciudadanía transnacional", en Fronteras Fragmentadas, Gail Mummert (ed.), Zamora, Mich, El Colegio de Michoacán, pp. 215-238.

2000 "Sentimientos (in)apropiados de las mujeres migrantes: Hacia una nueva ciudadanía", en Migración y relaciones de género en México, Dalia Barrera Bassols y Cristina Oehmichen Bazán (eds.), México, Grupo Interdisciplinario sobre Mujer, Trabajo y Pobreza/Universidad Nacional Autónoma de México/Instituto de Investigaciones Antropológicas, pp. 371-388. .

2004 Topografías transnacionales: Hacia una geografía de la vida transnacional, México, Universidad Autónoma Metropolitana-Iztapalapa / Plaza y Valdés.

BOORSTIN, Daniel

1964 The image: A Guide to pseudo-events in America, Nueva York, Harper y Row Publishes.

BORUCHOFF, Judith

1999 "Equipaje cultural: Objetos, Identidad y Transnacionalismo en Guerrero y Chicago", en Fronteras Fragmentadas, Gail Mummert (ed.), Zamora, Mich, El Colegio de Michoacán, pp.499-518.

BRAH, Avtar

1996 Cartographies of diaspora: contesting identities, Londres, Routledge. .

BROWN, Edward

Notes on Nostalgia, documento electrónico, http://bms.brown.edu/HistoryofPsychiatry/nostalgia.html [revisado 13 de junio de 2006].

BRUNER, Edward 
1989 "Of Cannibals, Tourists, and Ethnographers", en Cultural Anthropology, 4(4), pp. 438-445.

BUCKSER, Andrew

1999 "Keeping Kosher: Eating and Social Identity among the Jews of Denmark", en Ethnology, 38 (3), pp. 191-209.

BURNS, Peter M.

1999 An Introduction to Tourism \& Anthropology, Londres, Routledge.

CARO BAROJA, Julio

1979 El carnaval (análisis histórico-cultural), Madrid, Taurus.

CLIFFORD, James

1988 The Predicament of Culture: Twentieth-Century Ethnography, Literature, and Art, Cambridge, Harvard University Press.

1999 Itinerarios Transculturales, Barcelona, Gedisa.

CORNELIUS, Wayne A.

1989 "Mexican Migration to the United States: An Introduction", en Mexican Migration to the United States: Origins, Consecuences, and Policy Options, Wayne A. Cornelius y Jorge Bustamante (eds.), La Jolla, Calif., Bilateral Commission on the Future of U.S.-Mexican Relations, pp. 1-21. CRUZ, Mirian, Carlos LÓPEZ CERDÁN y Claudia SCHATAN (CEPAL, México)

2004 Pequeñas empresas, productos étnicos y de nostalgia: oportunidades en el mercado internacional: los casos de El Salvador y México, México, D.F., Naciones Unidas.

CHOW, Rei

1993 Writing Diaspora: Tactics of Intervention in Contemporary Cultural Studies, Indianápolis, Indiana University Press.

DAVIS, Mike

2000 Magical Urbanism: Latinos Reinvent the US City, Nueva Cork, VERSO.

DURAND, Jorge

1994 Más allá de la línea: Patrones migratorios entre México y Estados Unidos, México, Consejo Nacional para la Cultura y las Artes.

EBRON, Paulla A.

2000 "Tourists as pilgrims: commercial fashioning of transatlantic politics", en American Ethnologist, 25(4), pp. 910-932.

ECO, Umberto

1999 La estrategia de la ilusión, Barcelona, Lumen. 
ECO, Umberto, V. V. IVANOV y Monica RECTOR

1984 Carnival!, Berlin, Mouton Publishers.

ESPINOSA, Víctor M.

1998 El dilema del retorno: migración, género y pertenencia en un contexto transnacional, Zamora, Mich, El Colegio de Michoacán.

1999 "El día del emigrante y el retorno del purgatorio: Iglesia, migración a Estados Unidos y cambio sociocultural en un pueblo de los Altos de Jalisco", Estudios Sociológicos, XVII (50), pp. 375-418.

Expresión de los Altos

2002 Expresión de los Altos, año 3, diciembre.

2003 Expresión de los Altos, año 3, marzo.

2003a Expresión de los Altos, año 4, agosto.

FÁBREGAS PUIG, Andrés Antonio

1986 La formación histórica de una región: Los Altos de Jalisco, México, Centro de Investigaciones y Estudios Superiores en Antropología Social.

FAIST, Thomas

1999 "Developing Transnational Social Spaces: The Turkish-German

Examples", en Migration and Transnational Social Spaces, Ludgar

Pries(ed.), Aldershot, Ashgate, pp. 36-72.

FOUCAULT, Michel

1982 "The Subject and Power" en Michel Foucault: Beyond Structuralism and Hermeneutics, Hubert Dreyfus and Paul Rabinow (eds.), Chicago, University of Chicago Press, pp.208-226.

GARCÍA AGUIRRE, Apolinar

2003 "Jalos": A los ojos de un "Pinolillo", Zapopan, Amate editorial.

GARCÍA CANCLINI, Néstor, Amalia SIGNORELLI, Renato ROSALDO, Claudio

LOMNITZ, Richard N. ADAMS, Roberto VARELA, Jacques MAURAIS, Renato ORTIZ y Enzo SEGRE

1994 De lo local a lo global: Perspectivas desde la antropología, México, Universidad Autónoma Metropolitana-Iztapalapa.

GARCÍA GUTIÉRREZ, Marco A.

2002 "Toribio Romo González: Protector de los mojados", en Contenido, junio 1. 
GENNEP, Arnold van

1960 The Rites of Passage. Londres, Routledge \& Kegan Paul.

GILROY, Paul

1987 There Ain't No Black in the Union Jack, Londres, Hutchinson.

1993 The Black Atlantic: Double Consciousness and Modernity, Cambridge, Harvard University Press.

GLICK SCHILLER, Nina, Linda BASCH y Cristina BLANC-SZANTON

1992 "Transnationalism: A New Analitic Framework for Understanding Migration", en Towards a Transnational Perspective on Migration:Race, Class, Ethnicity and Nationalism Reconsidered, Nina Glick Schiller, Linda Basch y Cristine Blanc-Szanton (eds.), New York, Annuals of the New York Academy of Science, 645 (June), pp. 1-24.

1995 "From Immigrant to Transmigrant: Theorizing Transnational Migration", en Anthropological Quarterly, 68 (1), pp. 48-63.

GIICK SCHILLER, Nina y Georges FOURON

1990 "Everywhere we go, we are in danger: Ti Manno and the emergence of a Haitian transnational identity", en American Ethnologist, 17 (2), pp. 329347. .

GLICK SCHILLER, Nina y Linda BASCH

1992 "Transnational Projects of Immigrants and Ethnographers, and the Cultural Politics of Nation States", ponencia presentada en la reunión de la American Anthropological Association (AAA) en dieciembre de 1992 en San Francisco.

GOLDRING, Luin

1997 "Difuminando fronteras: Construcción de la comunidad transnacional en el proceso migratorio México-Estados Unidos", en Migración laboral internacional: Transnacionalidad del espacio social, Saúl Macías Gamboa y Fernando Herrera Lima (coord.), México, Universidad Autónoma de Puebla, pp. 55-105.

GONZÁLEZ DE LA ROCHA, Mercedes y Agustín ESCOBAR LATAPÍ

1990 "La ley y la migración internacional: el impacto de la 'Simpson- Rodino' en una comunidad de los Altos de Jalisco", en Estudios Sociológicos VIII (24), pp. 517-546.

GONZÁLEZ Y GONZÁLEZ, Luis 
1986 Invitación a la Microhistoria, México, FCE-SEP-CREA.

GRABURN, Nelson

1977 "Tourism: The Sacred Journey", en Hosts and Guests: The Anthropology of Tourism, Valenne L. Smith (ed.), Philadelphia, University of Pennsylvania Press, pp 17-31. .

GREENWOOD, Davydd J.

1977 "Culture by the Pound: An Anthropological Perspective on Tourism as Cultural Commoditization", en Hosts and Guests: The Anthropology of Tourism, Valenne L. Smith (ed.), Philadelphia, University of Pennsylvania Press, pp. 129-138

GUPTA, Akhil y James FERGUSON

1997 "Beyond 'Culture': Space, Identidad, and the Politics of Difference", en Culture, Power, Place: Explorations in Cultural Anthropology, Akhil Gupta y James Ferguson (eds.), Durham, Duke University Press, pp.3351.

GUTIÉRREZ, Atanasio y Sergio GUTIÉRREZ 2003 Viaje al corazón de los Altos, Guadalajara, México, Acento Editores. GUTIÉRREZ DE MANTECÓN, Guadalupe 2003 La Querencia, Guadalajara, México, Acento Editores.

GUTIÉRREZ GUTIÉRREZ, José Antonio

1985 Jalostotitlán a través de los siglos, Aguascalientes, Universidad Autónoma de Aguascalientes.

1996 "Introducción", en El cuadro estadístico de la municipalidad de Jalostotitlán 1880, Juan Macías Gutiérrez, México, Amigos de la Historia de los Altos de Jalisco, A.C., pp. 7-10.

GUTIÉRREZ HERMOSILLO, Alfonso

1946 Alfredo R. Placencia Antología poética, México, Universidad Nacional Autónoma de México.

GUTIÉRREZ R., Alfredo

2000 Xalostotitlán en Imágenes, Guadalajara, México, Acento Editores/Amate editorial.

GUTIÉRREZ Y GUTIÉRREZ, José Atanasio

2003 "Prólogo a la presente edición", en La Querencia, Guadalupe Gutiérrez de Mantecón, Guadalajara, México, Acento Editores, pp. 7-14.

GUZMÁN MUNDO, Fernando 
2004 "Santo Toribio Romo; Construcción histórica de un símbolo identitario", en El fenómeno religioso en el occidente de México, Cristina Gutiérrez Zúñiga (ed.), Guadalajara, México, El Colegio de Jalisco/Universidad de Guadalajara.

H. Ayuntamiento de Jalostotitlán

2002 Plan de Desarrollo Municipal, Jalostotitlán, H. Ayuntamiento de Jalostotitlán.

-

2003 Un Carnaval en los Altos: Breve historia de una fiesta, Jalostotitlán, H. Ayuntamiento de Jalostotitlán.

HALL, Stuart

1990 "Cultural Identity and Diaspora", en Identity: Community, Culture, Difference, Jonethan Rutherford (ed.), London, Lawrence and Wishart, pp. 222-237.

HANNERTZ, UIf

1989 "Culture Between Center and Periphery: Toward a Macroanthropology", Ethnos, 54, pp.200-216.

1998 Conexiones transnacionales: Cultura, gente, lugares, Madrid, Ediciones Cátedra.

HARVEY, David

2004 La condición de la posmodernidad: Investigación sobre los orígenes del cambio cultural, Buenos Aires, Amorrortu.

HAYES-BAUTISTA, David E.

2004 La Nueva California: Latinos in the Golden State, Berkeley, University of California Press.

HEGEL, Georg Wilhelm Fredrich

1999 Fenomenología del espíritu, Madrid, Fondo de Cultura Económica.

HERNÁNDEZ G., Abigail

2003 "El consumo de la nostalgia", documento electrónico, http://revistas.bancomext.gob.mx/Bancomext/rni/revista/septiembre2003/ PDF/consumo.pdf [revisado el 2 de noviembre de 2006].

HIERNAUX, Daniel

2000 "La fuerza de lo efímero: Apuntes sobre la construcción de la vida cotidiana en el turismo", en La vida cotidiana y su espacio-temporalidad, Alicia Lindón (coord.), Barcelona, Anthropos, pp. 95-122. . 
HIRABAYASHI, Lane Ryo

2002 "Reconsidering Transculturation and Power", en Asians in the Americas:

Transculturations and Power, Amerasia Journal, 28 (2), pp. ix-xxii.

HIRAI, Shinji

2002 Viajes nostálgicos al terruño imaginario:la reconstrucción del lugar y la cultura local en la comunidad transnacional a través de las contiendas de imágenes, tesis de maestría, Departamento de Antropología, Universidad Autónoma Metropolitana-Iztapalapa.

$-$

2003 "La comunidad transnacional jalostotitlense", pp.10-11, Sin fronteras, Año 1, No.2, diciembre de 2003.

HOBSBAWM, Eric y Terrence RANGER (eds.)

1983 The Invention of Tradition, Cambridge, Cambridge University Press.

HOSKINS, Janet

1998 Biographical Objects: How Things Tell the Stories of People's Lives, Nueva York, Routledge.

HUMPHREYS, Jeffrey M.

2000 "Buying Power at the Beginning of a New Century: Projections for 2000 and 2001", en Georgia Business and Economic Conditions, 60 (4), p. 14. .

INEGI

1984 X Censo General de Población y Vivienda, 1980, México.

1991 XI Censo General de Población y Vivienda, 1990. Resultados Definitivos. Tabulados Básicos, México.

2001 XII Censo General de Población y Vivienda, 2000. Resultados Definitivos. Tabulados Básicos, México.

2002 XII Censo General de Población y Vivienda, 2000. Principales Resultados por Localidad, México.

2006 II Conteo de Población y Viviendas, 2005. Resultados Definitivos. Tabolados Básicos, México.

ISHIKAWA, Noboru 
1993 "Noumin to Oufukukippu: Jyunkan roudou imin to comyunity kenkyū no zensen", en Minzokugaku Kenkyū (The Japanese Journal of Ethnology), 58 (1), pp. 53-71. .

JAMESON, Fredric

1984 "Postmodernism, or the Cultural Logic of Late Capitalism", en New Left Review, 146, pp. 53-92.

JÁUREGUI PÉREZ, Severiano

1981 El libro de los talentos, Los Angeles, Difusora Cultural Los Talentos.

JIMÉNEZ, Víctor Manuel

2006 "La fiesta de Xipe o Carnaval", en Revista Seis, p.3.

KEARNEY, Michael

1991 "Borders and Boundaries of State and Self at the End of the Empire", en Journal of Historical Sociology, 4(1), pp. 52-74.

1995 "The Local and the Global: The Anthropology of Globalization and Transnationalism", en Annual Review of Anthropology, 24, pp. 547-565.

KEARNEY, Michael y Carole NAGENGAST

1989 Anthropological Perspectives on Transnational Communities in Rural California, Working Group on Farm Labor and Rural Poverty Working Paper No. 3, Davis, California, California Institute for Rural Studies.

KUPER, Adam

2000 Culture: The Anthropologists' Account, Cambridge, Harvard Univarsity Press.

LASH, Scott y John URRY

1987 The End of Organized Capitalism, Cambridge, Polity Press.

LE ROY LADURIE, Emmanuel

1979 Carnival in Romans, Nueva York, George Braziller.

LEFEBVRE, Henri.

1974 La production de l'espace social, París, Anthropos.

LEVITT, Peggy

2001 The Transnational Villagers, Berkeley, University of California Press.

LEVITT, Peggy y Nina GLICK SCHILLER

2004 "Perspectivas internacionales sobre migración: Conceptualizar la simultaneidad", en Migración y Desarrollo, segundo semestre, pp. 60-91.

LÓPEZ ÁNGEL, Gustavo y Thoric Nils CEDESTROM 
1991 "Moradores en el purgatorio: el regreso periódico de los migrantes como una forma de peregrinación", en Memoria del Simposio Internacional de Investigadores Regionales, Puebla, Instituto Nacional de Antropología e Historia.

LÓPEZ CORTÉS, Eliseo

1999 Último cielo en la cruz: Cambio sociocultural y estructuras de poder en Los Altos de Jalisco,Guadalajara, México, Sistema de Educación Media Superior de la Universidad de Guadalajara/El Colegio de Jalisco.

LÓPEZ ULLOA, José Luis

2002 Tierra, familia y religiosidad en los Altos de Jalisco: la construcción de una identidad, 1880-1940, tesis de maestría, Departamento de Historia, Universidad lberoamericana.

LORENZANO, Sandra

2004 "El camino del recuerdo. Viajes y exilios en la narrativa argentina", en Espacio, viajes y viajeros, Luz Elena Zamudio (coord.), México, Universidad Autónoma Metropolitana-Iztapalapa, pp. 239-262.

LUTKEHAUS, Nancy Christine

1989 '"EXCUSE ME, EVERYTHING IS NOT ALL RIGHT': On Ethnography, Film, and Representation", en Cultural Anthropology, 4(4), pp. 422-437.

MACÍAS GUTIÉRREZ, Juan

1996 El cuadro estadístico de la municipalidad de Jalostotitlán 1880, México, Amigos de la Historia de los Altos de Jalisco, A.C.

MAEYAMA, Takashi

1994 "Postcolonialism and Cultural anthropology", en Shakai jinruigaku nenpō, 20, Departamento de Antropología Social de la Universidad Metropolitana de Tokyo (ed.), Tokyo, Koubundō, pp. 1-25. .

MANDEL, Ernst

1978 Late Capitalism, Londres, New Left Books.

MARCUS, George E.

1998 Ethnography through Thick and Thin, Princeton, Princeton University Press.

MARCUS, George E. y Michael MJ. FISCHER

1986 Anthropology as cultural critique: An Experimental moment in the Human Sciences, Chicago, University of Chicago Press.

MARTíNEZ CASAS, Regina y Guillermo DE LA PEÑA 
2004 "Migrantes y comunidades morales: resignificación, etnicidad y redes sociales en Guadalajara (Méjico)", en Revista de Antropología Social, 13, pp. 217-251.

MARX, Karl

1976 Manuscritos económicos y filosóficos de 1844, México, Cultura popular. MASSEY, Douglas

1995 "The New Immigration and Ethnicity in the United States", en Population and Development Review, 21 (3), pp. 631-652.

MASSEY, Douglas, Rafael ALARCÓN, Jorge DURAND y Humberto GONZÁLEZ

1991 Los ausentes: El proceso social de la migración internacional en el occidente de México, México, Alianza Editorial/CONACULTA.

Mi Tierra

2000 "Hijos ilustres de mi tierra: Biografía Santo Toribio Romo, Sacerdote", en Mi Tierra, 1 (1), pp. 2-6. .

Milenio

2006 "Van Pymes por el nicho hispano en EU", en Milenio, octubre 31, documento electrónico, http://www.milenio.com/mexico/milenio/imprime. asp?id=81384 [revisado el 2 de noviembre de 2006].

MINES, Richard y Sandra NICHOLS

2005 The Mexican Mercado Paisano: A framework to study its development potential in migrant-dependent communities, documento electrónico, http://geocommunities.org/metaPage/lib/Merc-Paisano-Paper-12-05.pdf [revisado el 30 de octubre de 2006].

MONTES GARCÍA, Olga

1992 "La migración en la Sierra Norte: sus cambios culturales", en Migración y Etnicidad en Oaxaca, Jack Corbett, Murad Musalem Merhy, Othón C. Río Vázquez y Héctor A. Vázquez Hernández (eds.), Nashville, Tennessee, Vanderbilt University Publication in Anthropology, pp. 87-94.

MORALES HERNÁNDEZ, Jaime

2004 Sociedades rurales y naturaleza: En busca de alternativas hacia la sustentabilidad, México, Instituto Tecnológico y de Estudios Superiores de Occidente/Universidad Iberoamericana León.

MORRISON, Toni

1990 "The Site of Memory", en Out There: Marginalization and Contemporary Cultures, Russell Ferguson, Martha Gever, Trinh T. Minh-ha y Cornel West (eds.), Cambridge, MIT Press, pp. 299-305. 
OLMEDO CARRANZA, Bernardo

2006 "Importancia de los Mercados de la Nostalgia, Elaboración de Productos Étnicos y Pymes", ponencia presentada en la Escuela de Planificación y Promoción Social de la Universidad Nacional de Costa Rica (UNA), dentro de las actividades académicas por la Inauguración del II Ciclo 2006, Heredia, Costa Rica, 7 al 11 de agosto.

OROZCO, Luis Alfonso

2005 “Toribio Romo González, Santo. El santo protector de los 'mojados"', en Madera de Héroes: semblanza de algunos héroes mexicanos de nuestro tiempo, Luis Alfonso Orozco (ed.), México, Arca.

ORTIZ, Fernando

1995 Cuban Counterpoint: Tobacco nd Sugar, Durham, Duke University Press. OTA, Yoshinobu

1993 "Objectification of Culture: The Creation of Culture and Identity in the Tourist World", en Minzokugaku Kenkyū (The Japanese Journal of Ethnology), 57(4), pp. 383-410.

Our Lady of Guadalupe Roman Catholic Church

1997 Our Lady of Guadalupe Church Family Album, La Habra, Our Lady of Guadalupe Roman Catholic Church.

PADILLA L., José Trinidad

1988 Con los brazos abiertos: Historia de la Imagen de la Virgen de la Asunción que se venera en Jalostotitlán, Jalisco, México, Calypso.

PARK, Kyeyoung

2002 “'10,000 Señoras Lees': The Changing Gender Ideology of KoreanLatina-American Women in the Diaspora" en Asians in the Americas:

Transculturations and Power, 28 (2), Lane Ryo Hirabayashi y Evelyn HuDeHart (eds.), pp.161-180.

PORTAL ARIOSA, María Ana

1994 "Las peregrinaciones y la construciión de fronteras simbólicas", en Las peregrinaciones religiosas: una aproximación, Carlos Garma Navarro y Roberto Shadow (coords.), México, Universidad Autónoma Metropolitana-Iztapalapa, pp. 141-153.

PORTES, Alejandro y John WALTON

1981 Labor, Class, and the International System, Nueva York, New York Academic Press.

PRATT, Mary Louise 
1992 Imperial Eyes: Travel Writing and Transculturation, Londres, Routledge.

QUIROZ MALCA, Haydée

2000 Fiestas, peregrinaciones y santuarios en México: Los viajes para el pago de las mandas, México, CONACULTA.

RAMÍREZ, Blanca y Patricia ARIAS

2002 "Hacia una nueva rusticidad", en CIUDADES 54, pp. 9-14..

RAMÍREZ JIMÉNEZ, Luis Jesús

2002 Casonas del Pasado en el Corazón de los Altos de Jalisco, Jalostotitlán, Gráfica Positiva.

RAMÍREZ, José R.

1992 Antología Alfredo R. Placencia, México, Seminario de Guadalajara.

RAMÍREZ RAMÍREZ, César

1998 Antología, Jalostotitlán, Gráfica Positiva.

RAYMOND, Williams

1977 Marxism and Literature, Oxford, Oxford University Press.

REDFIELD, Robert

1941 The Folk Culture of Yucatan, Chicago, University of Chicago Press.

-

1950 A Villege That Chose Progress: Chan Kom Revisited, Chicago, University of Chicago Press.

REDFIELD, Robert, Ralphy LINTON y Melvilla J. HERSKOVITS

1935 "A memorandum for the study of acculturation," en American Anthropologist, 38 (3), pp. 149-152.

ROBERTSON, Jennifer

1991 Native and Newcomer: Making and Remakeing a Japanese City, Berkley, University of California Press.

RODRíGUEZ LOMELÍ, Pedro

1976 En un Pueblo Alteño, Guadalajara, México, Ensayos literarios.

ROSALDO, Renato

1989 Culture and Truth: The Remaking of Social Analysis, Boston, Beacon Press.

1994 "Ciudadanía cultural en San José, California", en De lo local a lo global:

Perspectivas desde la antropología, Néstor García Canclini et al., México, Universidad Autónoma Metropolitana-Iztapalapa, pp. 67-88.

ROSEN, George 
1975 “Nostalgia: A ‘Forgotten’ Psychological Disorder”, en Clio Medica, 10 (1), pp. 28-51.

ROTH, Michael

1991 "Dying of the Past: Medical Studies of Nostalgia in Nineteenth-Centuryu France", en History and Memory, 3, pp. 5-29.

ROUSE, Roger

1989 Mexican Migration to the United States: Family Relations in the Development of a Transnational Migrant Circuit, tesis de doctorado, Departamento de Antropología, Stanford, Stanford University.

1991 "Mexican Migration and the Social Space of Postmodernism", en Diaspora, 1(1), pp. 8-23.

RUSHDIE, Salman

1991 "Imaginary Homelands", en Golden ages, dark ages: Imagining the past in Anthropology and History, Jay O'Brien y William Rosberry (eds.), Berkley, University of California Press, pp. 9-21.

SAFRAN, William

1991 "Diaspora in Modern Societies: Myths of Homeland and Return", en Diaspora, 1 (1), pp. 83-99.

SÁNCHEZ RODRÍGUEZ, Alberto 2003 “Jalos, Pueblo de Viajeros", en Sin Fronteras, 1 (2). SEDIKIDES, Constantine , Tim WILDSCHUT y Denise BADEN

2004 "Nostalgia: Conceptual Issues and Existential Functions", en Handbook of Experimental Existential Psychology, Jeff Greenberg (ed.), Nueva York, Guilford Press, pp. 200-214.

SIMPSON, Edward

2005 "The 'Gujarat' earthquake and the political economy of nostalgia", en Contributions to Indian Sociology, 39 (2), pp. 219-249.

Sin Fronteras

2003 Sin Fronteras, 1 (1).

SMITH, Valenne L. (ed.)

1977 Hosts and Guests: The Anthropology of Tourism, Philadelphia, The University of Pennsylvania Press.

STEWART, Kathleen

1988 "Nostalgia-A Polemic", en Cultural Anthropology, 3(3), pp. 227-241. The Orange County Register 
2003 The Orange County Register, agosto 17.

-

2003a The Orange County Register, junio 1.

TURNER, Victor

1967 The forest of symbols: Aspects of Ndembu ritual, Ithaca, Cornell University Press.

1969 The Ritual Process: Structure and Anti-structure, Chicago, Aldine.

1974 Dramas, Fields and Metaphors: Symbolic Action in Human Society, Ithaca, Cornell University Press.

TURNER, Victor y Edith TURNER

1978 Image and pilgrimage in Christian culture: Anthropological Perspectives, Nueva York, Colombia University Press. .

U.S. Census Bureau

1950-2000 April Decennial of Population, Washington, D.C.

-

20002000 Census, Washington, D.C.

URRY, John

1990 The Tourist Gaze, Londres, Sage Publications.

1995 Consuming places, Londres, Routledge.

VÁZQUEZ CORREA, Luis

1959 Poesías (Alfredo R. Placencia), Guadalajara, México, Casa de la Cultura Jalisciense.

VERGARA FIGUEROA, Abilio

2001 "Horizontes del imaginario. Hacia un reencuentro con sus tradiciones investigativas", en Imaginarios: horizontes plurales, Abilio Vergara

Figueroa (ed.), México, Escuela Nacional de Antropología e Historia, pp. 11-83.

VERTOVEC, Steven

2003 "Migration and other Modes of Transnationalism: Towards Conceptual Cross-Fertilization", en International Migration Review, 37 (3), pp. 641 665.

WAI-TENG, Leong 
1989 "Culture and the State: Manufacturing traditions for Tourism", en Critical Studies in Mass Communication, 6, pp. 355-375.

WILLIAMS, Raymond

1973 The Country and the City, Nueva York, Oxford University Press.

1977 Marxism and literature, Londres, Oxford University Press.

WOLF, Eric R.

1957 "Closed Corporate Peasant Communities in Mesoamerica and Central Java", en Southwestern Journal of Anthropology, 13, pp. 1-18.

YAMASHITA, Shinji

1996 “'Rakuen' no Souzou: Bali niokeru Kankō to Dentō no Saikouchiku", en Kankō Jinruigaku, Shinji Yamashita (ed.), Tokio, Shinyousha, pp. 104112. 